
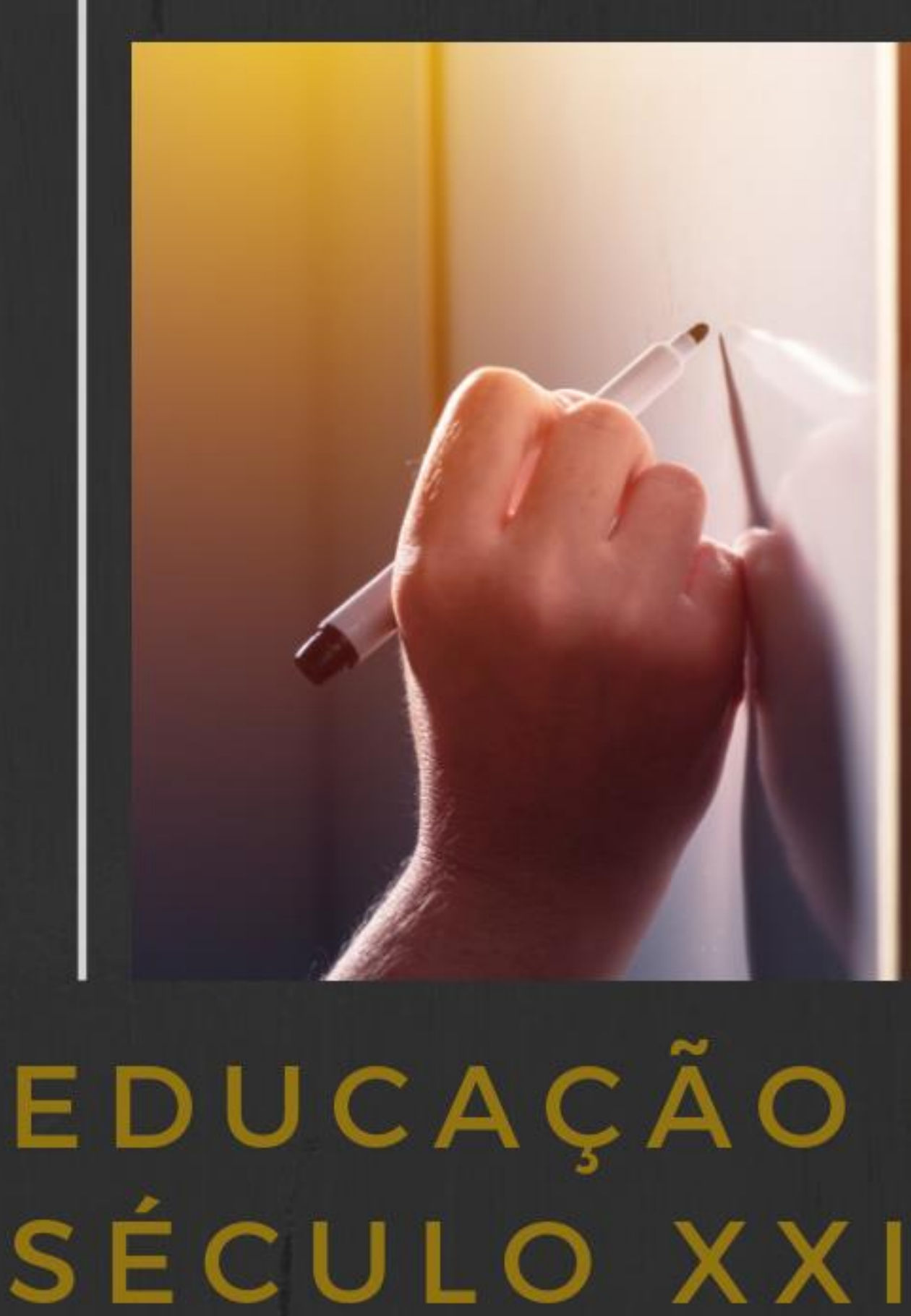

Formaçầo Docente

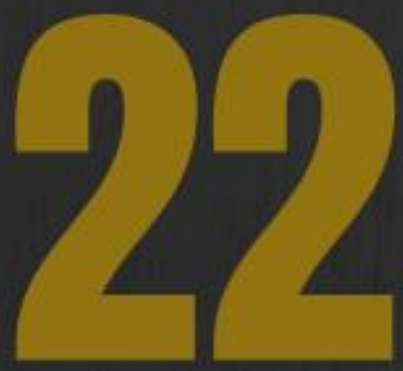

\title{
VOLUME
}

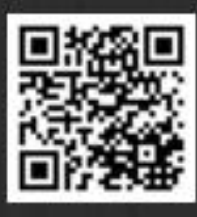

Editora Poisson 
Editora Poisson

\section{Educação no Século XXI - Volume 22 Formação Docente}

1a Edição

Belo Horizonte

Poisson

2019 


\section{Editor Chefe: Dr. Darly Fernando Andrad5}

\section{Conselho Editorial}

Dr. Antônio Artur de Souza - Universidade Federal de Minas Gerais

Ms. Davilson Eduardo Andrade

Msc. Fabiane dos Santos Toledo

Dr. José Eduardo Ferreira Lopes - Universidade Federal de Uberlândia Dr. Otaviano Francisco Neves - Pontifícia Universidade Católica de Minas Gerais

Dr. Luiz Cláudio de Lima - Universidade FUMEC

Dr. Nelson Ferreira Filho - Faculdades Kennedy

Ms. Valdiney Alves de Oliveira - Universidade Federal de Uberlândia

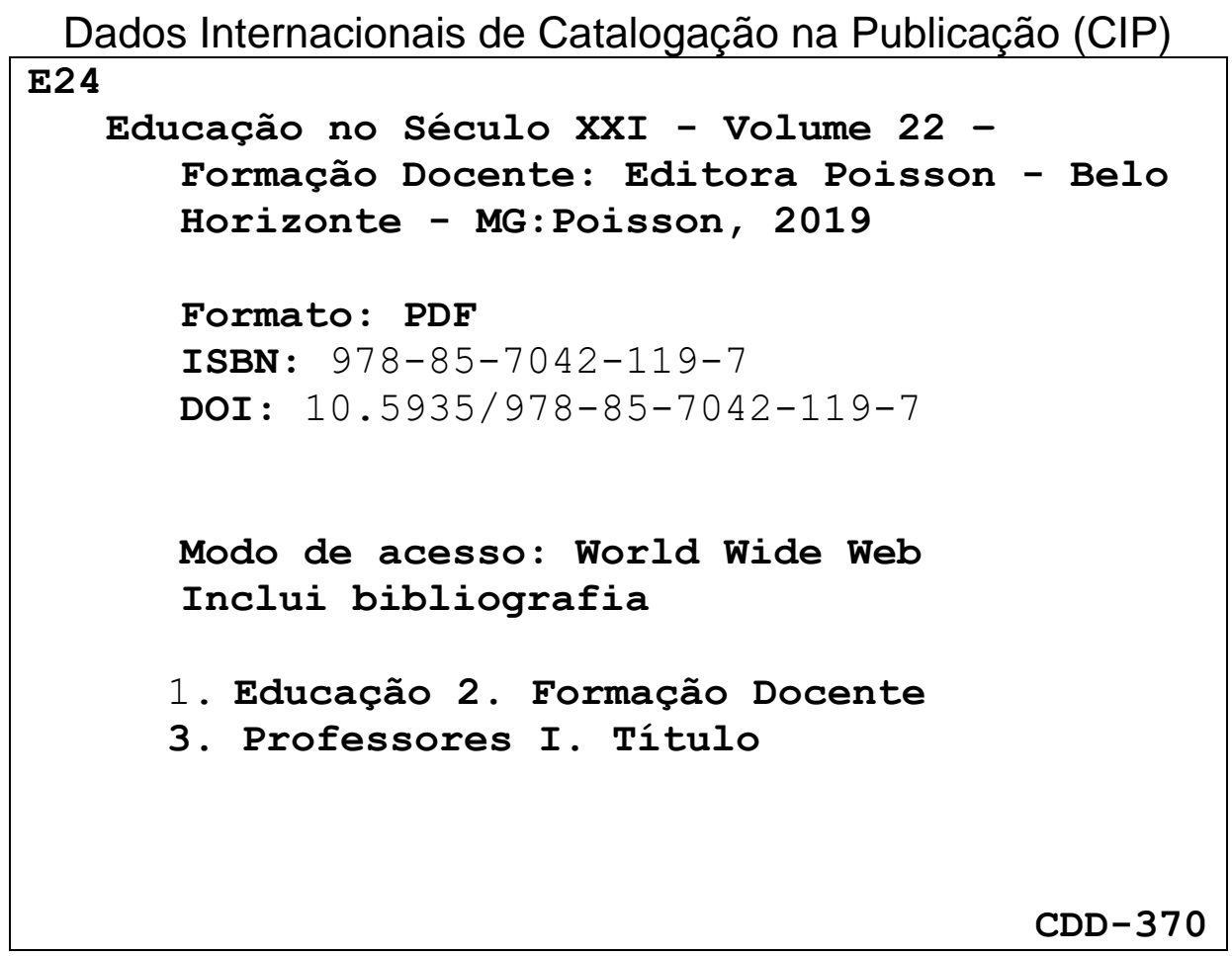

O conteúdo dos artigos e seus dados em sua forma, correção e confiabilidade são de responsabilidade exclusiva dos seus respectivos autores

$\underline{\text { www.poisson.com.br }}$

contato@poisson.com.br 


\section{SUMÁRIO}

Capítulo 1: PIBID Pedagogia e o ensino da matemática: Princípios e possibilidades para a formação inicial de professores .

Edilson de Araújo dos Santos, Luciana Figueiredo Lacanallo Arrais

Capítulo 2: O PIBID de matemática numa escola pública de Natal/RN: Perspectivas metodológicas dentro e fora da sala de aula. 14 Querem Apuque Felix de Andrade Marinho, Pérola Diana Gomes Felipe, Mirella Ingrid Oliveira da Cruz, Valdeniz da Silva Cruz Junior

Capítulo 3: Educação moral na escola: O trabalho do PIBID de psicologia com o ensino médio. 20

Priscila Vargas Gatti, Jaqueline Batista de Oliveira Costa

Capítulo 4: O PIBID pedagogia em uma escola do campo: O foco na leitura e escrita dos anos iniciais do ensino fundamental

Amanda Nascimento Silva de Oliveira, Maria Joselma do Nascimento Franco

Capítulo 5: Formação inicial de professores: Constituição dos saberes docentes nas ações do PIBID.

Anna Raquel da Silva Marinho, Rogério Emílio da Silva, Francisco das Chagas da Silva Junior, Pauleany Simões de Morais

Capítulo 6: A importância do profissional licenciado em informática na rede pública de ensino e sua valorização por meio do PIBID. 40

Janiele da Siva Costa, Givanaldo Rocha de Souza, Francisco das Chagas da Silva Junior, Pauleany Simões de Morais

Capítulo 7: Concepção de infância e as aulas de artes: reflexões a partir da experiência do Programa Institucional de Bolsas de Iniciação à Docência (PIBID) Artes Visuais UNESC/2012-2013. 46

Juliana Pereira Guimarães, Silemar Maria de Medeiros da Silva

Capítulo 8: As tensões presentes na formação docente: Práticas de estágio como matizes da construção dos saberes dos professores. 56

Janaina Boniatti Bolson

Capítulo 9: Experiência de estágio curricular: Contribuição aos saberes e formação docente. 


\section{SUMÁRIO}

Capítulo 10: 0 início de uma trajetória: A escolha profissional do curso de pedagogia e as representações sociais dos estudantes. 73

Thamyris Mariana Camarote Mandú, Maria da Conceição Carrilho de Aguiar

Capítulo 11: Inclusão em educação na formação docente em biologia 81 André Fillipe de Freitas Fernandes, Débora de Aguiar Lage

Capítulo 12: Alfabetização científica na formação de professores: Indicadores do processo em registros escritos de licenciandos em biologia

Karla Jeane Coqueiro Bezerra Soares, Mariana Guelero do Valle

Capítulo 13: A docência na educação infantil: A constituição de uma docente de bebês 98

Maria Paula Ferreira Maia da Silva, Celi da Costa Bahia

Capítulo 14: A formação do (a) professor (a) alfabetizador (a): Um olhar crítico para a sua prática 105

Amanda Tayse de Sena Silva Santos, Manuella Patricio Menezes, Maria do Socorro Moura Montenegro

Capítulo 15: Necessidades formativas docentes para alfabetizar letrando em salas multisseriadas: 0 estabelecido nos documentos oficiais e a perspectiva de professoras 110

Telma Maria de Freitas Araújo, Maria Estela Costa Holanda Campelo

Capítulo 16: Formação de professores e trabalho docente no ensino médio: Uma análise dos trabalhos da ANPED 120

Néryla Vayne Alves Dias, Patrícia Regina de Souza, Renata Portela Rinaldi

Capítulo 17: Formação de professores para atuação na educação profissional e tecnológica - Horizontes possíveis

Rosangela Santos da Silva, Adriana Neves de Almeida, Luciani Andrade de Andrade, Ana Cláudia Ribeiro de Souza

Capítulo 18: Formação continuada: De quem, para quem? 138

Maria Elba Soares, Claudia Christina Bravo e Sá Carneiro 


\section{SUMÁRIO}

Capítulo 19: Formação continuada de professores: Desafios e dificuldades do exercicio da docência 145

Luiz Anselmo Menezes Santos, Sirleia Pereira Silva Gomes

Capítulo 20: A formação continuada de professores nas representações sociais dos formadores

Renata da Costa Lima, Maria da Conceição Carrilho de Aguiar

Capítulo 21: Formação continuada recursos tecnológicos e a organização do trabalho docente com sequências didáticas: Percepções dos professores cursistas. 164

Leida Gilvane Cantalice Ribeiro, Milene Mírian Araújo Monteiro, Josiano Regis Caria, Ieda Lucia de Oliveira Santana, Izabel Silva Bragança Pinheiro, Aldemira de Araújo Câmara

Capítulo 22: 0 processo de formação continuada de professores no estado de Goiás: Entre os dispositivos legais e a prática docente cotidiana.

Hugo Gabriel da Silva Mota, Daniel Mallmann Vallerius, Leovan Alves dos Santos

Capítulo 23: As contribuições da metodologia de projetos para a construção de saberes significativos e da formação continuada dos professores no contexto das escolas municipais de campo verde. 183

Simoni Pereira Borges, Adriana Sampaio Tibery, Edione Teixeira de Carvalho

Autores 186 


\section{Capítulo 1}

\section{PIBID Pedagogia e o ensino da matemática: Princípios e possibilidades para a formação inicial de professores $^{1}$}

\section{Edilson de Araújo dos Santos}

\section{Luciana Figueiredo Lacanallo Arrais}

Resumo: O presente trabalho busca relatar a experiência de uma intervenção pedagógica realizada pelos acadêmicos pertencentes ao Programa Institucional de Bolsas de Iniciação a Docência - PIBID. Este programa atua diretamente com a formação inicial de professores, em que os acadêmicos estão em contato direto com as instituições de ensino. Nas formações do Pibid na universidade e na escola destinamos momentos para pesquisa e planejamento de intervenções pedagógicas. As situações e recursos são pensados e problematizados no grupo e pelo grupo, no intuito de colocar o futuro professor em movimento de ensino e aprendizagem. A intervenção pedagógica que aqui será apresentada teve como temática o conceito de agrupamento, no qual se buscou pensar em recursos que materializassem os pressupostos teóricos que estudamos e defendemos, foi necessário pesquisarmos o conceito em si, afinal o que seria agrupamento na matemática. No primeiro momento utilizamos de uma situação desencadeadora de aprendizagem com base no livro, "As centopeias e seus sapatinhos" de Milton Camargo, que já vinha sendo trabalhado nas instituições em que o Pibid/Pedagogia/Foco: Matemática atua. Posteriormente, coma necessidade que os alunos compreendessem melhor esse modo de contagem recorremos ao jogo de regras por consideramos como um recurso que potencializa a aprendizagem e que foge das situações "escolarizadas" quando encaminhados com intencionalidade. O jogo que utilizamos em nossa intervenção foi de autoria dos acadêmicos, nomeamos o jogo como "Calçando a centopeia". Para iniciar o jogo elaboramos uma Situação Desencadeadora de Aprendizagem - SDA, com base nos pressupostos da Atividade Orientadora de Ensino AOE, Moura (1996, 2002).

Palavras-chave: Anos Iniciais. Educação Matemática. Jogo de regras. Organização do ensino. Agrupamento. 


\section{INTRODUÇÃO}

O ensino da matemática vem encontrando inúmeras dificuldades no contexto escolar sejam na dimensão dos conceitos, sejam nas dimensões pedagógicas, política e formativa. Relatos de experiência feitos por alunos em sala de aula no curso de Pedagogia revelam que a situação do ensino da matemática encontrase fragilizada. Esta situação também se comprova nos resultados das avaliações nacionais como o SAEB (desde 1990) e Prova Brasil (desde 2005), além das internacionais como PISA (desde 2000), que indicam um desempenho abaixo do esperado dos alunos para os anos em que estudam e para a idade cronológica. "Nossas crianças não sabem matemática", "Matemática é muito difícil", "Eu não gosto de matemática", são queixas presentes no cotidiano escolar. Essas queixas historicamente acompanham o ensino dessa ciência e, ainda hoje continuam a desafiar os educadores de modo geral. Buscando reverter esse processo, educadores e pesquisadores buscam elaborar encaminhamentos, recursos e atividades pedagógicas que possibilitem o aprendizado dos escolares.

Nessa direção, uma das possibilidades de revertermos esse cenário educacional é ampliarmos os investimentos na formação inicial de professores, no intuito de elevar a qualidade da ação docente e melhor capacitar esse profissional para atuar na educação básica. Desse modo, são ofertados pelo governo federal programas de incentivo a formação docente, visando à melhor preparação desse professor e a melhoria do seu trabalho pedagógico em sala de aula, com vistas a assegurar o ensino efetivo aos alunos.

Dentre esses programas, destacamos em especial, o PIBID-Programa Institucional de Bolsas de Iniciação a Docência que atua diretamente com a formação inicial de professores da Educação Básica. O Pibid é um projeto que busca incentivar a qualificação do futuro docente, no desenvolvimento estudos teóricospráticos. Esse programa visa desenvolver atividades didático-pedagógicas com auxílio de um docente da graduação e de um professor da escola de rede pública da educação básica conforme exigências estabelecidas pela Capes. De acordo com o site da Capes (2017, s/p.) o programa tem como objetivos:

- Incentivar a formação de docentes em nível superior para a educação básica;

- $\quad$ contribuir para a valorização do magistério;

- $\quad$ elevar a qualidade da formação inicial de professores nos cursos de licenciatura, promovendo a integração entre educação superior e educação básica;

- $\quad$ inserir os licenciandos no cotidiano de escolas da rede pública de educação, proporcionando-lhes oportunidades de criação e participação em experiências metodológicas, tecnológicas e práticas docentes de caráter inovador e interdisciplinar que busquem a superação de problemas identificados no processo de ensino-aprendizagem;

- incentivar escolas públicas de educação básica, mobilizando seus professores como coformadores dos futuros docentes e tornando-as protagonistas nos processos de formação inicial para o magistério; e

- contribuir para a articulação entre teoria e prática necessárias à formação dos docentes, elevando a qualidade das ações acadêmicas nos cursos de licenciatura.

No Curso de Pedagogia (campus sede) da Universidade Estadual de Maringá-UEM o Pibid é desenvolvido desde 2012, porém a configuração que está presente no projeto atual, no curso iniciou-se em 2014. Atualmente, o projeto conta com três focos de atuação: Anos Iniciais do Ensino Fundamental: Matemática; Anos Iniciais do Ensino Fundamental: Alfabetização e Letramento; e Gestão Escolar.

Nesse trabalho, apresentaremos as contribuições das ações realizadas com o Pibid nos Anos Iniciais do Ensino Fundamental com a área da Matemática. 0 foco da matemática conta com 19 acadêmicos do curso de Pedagogia (do $2^{\circ}$ ao $4^{\circ}$ ano), três supervisoras das escolas municipais de Maringá - PR e uma coordenadora, docente do departamento do curso de Pedagogia. Nesse foco, buscamos proporcionar por meio de práticas intencionais, sistematizadas e lúdicas, a apropriação da linguagem matemática. Ressaltamos que o Pibid não fornece aos seus acadêmicos a receita para ser professor, estamos/estaremos sempre em movimento de estudo para melhorar a organização do ensino e ampliar possibilidades de aprendizagem e desenvolvimento.

Tendo como pressupostos teórico-metodológico a teoria histórico-cultural, a Teoria da Atividade-TA e a Atividade Orientadora de Ensino-AOE, buscamos desenvolver atividades pedagógicas que auxiliem na melhoria do ensino. Portanto, em nossos estudos e atividades buscamos inserir esses pressupostos como forma de aproximar a teoria da prática. 
Nesse trabalho, apresentamos um relato de experiência um dos resultados dos trabalhos desenvolvidos nos três primeiros anos do projeto (2014-2016), em turmas de $2^{\circ}$ ano do Ensino Fundamental, com o conceito de Agrupamento. A Situação Desencadeadora de Aprendizagem-SDA foi organizada a partir dos pressupostos da AOE, a qual denominamos de "Os sapatos da centopeia". Esperamos com esse trabalho contribuir para a divulgação de práticas pedagógicas que possam instrumentalizar os professores no desafio da promoção dos conceitos matemáticos.

\section{A ORGANIZAÇ̃̃O DO ENSINO DE MATEMÁTICA: EM BUSCA DE REFERENCIAIS}

Com o Pibid-Pedagogia foco Matemática buscamos organizar as intervenções pedagógicas seguindo os princípios da teoria histórico-cultural elaborada por Vygotsky e seus colaboradores; da Teoria da Atividade de Leontiev $(1983 ; 2004 ; 2006)$ e da Atividade Orientadora de Ensino, proposta por Moura (1996; 2001).

Adotamos esses pressupostos, pois de acordo com eles, a instrução escolar tem papel decisivo na aprendizagem e no desenvolvimento psíquico do homem. Isso porque, embora todo homem, ao nascer já seja candidato a ser humano, o fato determinante em seu processo de humanização serão as interações culturais, as condições objetivas e as circunstâncias que este estiver inserido.

Dessa forma, a escola precisa buscar estratégias e recursos que possam contribuir para a aquisição de conceitos e o desenvolvimento dos alunos assegurando a aprendizagem de conteúdos curriculares. Para Bogoyavlensky e Menchinskaya (2005, p.43) "a educação e o ensino não esperam pela maturação das funções psíquicas, mas estimulam e condicionam o seu desenvolvimento". Essa afirmação reforça mais uma vez a necessidade da escola e de que as ações realizadas nesse espaço tenham qualidade a ponto de mobilizarem as capacidades intelectuais dos envolvidos no processo educativo.

No intuito de assegurar essa qualidade nas ações e tarefas propostas pela escola, Moura (1993; 2001) propõe uma possibilidade teórico- metodológica para o ensino de matemática a Atividade Orientadora de Ensino - AOE. A AOE é uma proposta de organização do ensino que subsidia a formação docente comprometida o desenvolvimento humano dos sujeitos envolvidos no processo: professores e alunos. De acordo com Moura et al (2010, p. 218)

$\mathrm{Na}$ AOE, ambos, professor e aluno, são sujeitos em atividade e como sujeitos se constituem como indivíduos portadores de conhecimentos, valores e afetividade que estarão presentes no modo como realizarão as ações que têm por objetivo um conhecimento de qualidade nova.

Adotar a AOE como base para organizar o ensino, implica em considerar dois sujeitos em atividades que se complementam, evitando aquela separação entre quem ensina quem aprende. 0 professor assume como atividade principal o ensino e o aluno tem como atividade principal a aprendizagem, esse movimento, de acordo com Moura (2010, p. 220), estabelece "elemento de mediação entre a atividade de ensino e a atividade de aprendizagem", impossibilitando que se separe atividade de ensino e atividade de aprendizagem. Ao integrar essas atividades busca-se promover a "apropriação dos estudantes da experiência histórica acumulada, pela via do pensamento teórico e dos conceitos científicos, visando ao desenvolvimento do psiquismo, das funções psíquicas superiores" (MOURA, 2010, p. 220).

Este modo de organização do ensino tem como conteúdo principal os conhecimentos teóricos, já que por meio deles será promovida a "constituição do pensamento teórico do indivíduo no movimento de apropriação do conhecimento" (MOURA, 2010, p. 221). Para tanto, a autor apresenta algumas formas de desenvolver uma AOE, que partem de situações desencadeadoras de aprendizagem, que contemplem a gênese do conceito e revelam a necessidade histórica que motivou a construção desse conceito.

A AOE pode ser materializada por meio de jogos, de situações emergentes do cotidiano e da história virtual do conceito (MOURA, 2010). Neste trabalho, relataremos, como por meio de um jogo adequado aos pressupostos da AOE, desenvolvemos uma situação de ensino com alunos de uma turma de segundo ano do Ensino Fundamental com o conteúdo agrupamento.

\section{EM BUSCA DE POSSIBILIDADES DIDÁTICAS}

Em nossas formações do Pibid na universidade e na escola destinamos momentos para pesquisa e planejamento de intervenções pedagógicas. As situações e recursos são pensados e problematizados no grupo e pelo grupo, no intuito de colocar o futuro professor em movimento de ensino e aprendizagem. 
Dentre as situações vivenciadas, uma, em especial, despertou nossa atenção pelo movimento que viabilizou entre os acadêmicos e os alunos da escola básica. A partir da proposta feita aos pibidianos pela equipe pedagógica das escolas que recebem o Pibid, o conceito da intervenção foi agrupamento. Para que pudéssemos pensar em recursos que materializassem os pressupostos teóricos que estudamos e defendemos, foi necessário pesquisarmos o conceito em si, afinal o que seria agrupamento na matemática.

Fizemos um trabalho de pesquisa em livros de matemática e em outros de didática da matemática, aliando o conceito em si às necessidades que levaram os homens a criarem o mesmo. Foi difícil essa fase dos trabalhos, pois muitas vezes, mesmo que já tenhamos visto esse conceito em nossa vida escolar, nos demos conta que de fato não sabíamos como explicar aos alunos, ou seja, nossa compreensão mostrou-se falha e vaga diante do que seria agrupar.

Após esse momento, dentre as possibilidades de materializar a AOE, optamos pela elaboração de um jogo que mobilizasse os alunos a pensarem na necessidade desse conceito matemático. Neste sentido, buscamos compreender quais as contribuições do jogo para o processo educativo e em nossos estudos observamos que o professor ao utilizá-lo deve realizá-lo com intencionalidade, pois

Ao tomarmos o jogo como ferramenta do ensino, ele passa a ter novas dimensões, e é isto que nos obriga a classificá-lo considerando o papel que pode desempenhar no processo de aprendizagem. 0 jogo pode, ou não, ser jogo no ensino. Ele pode ser tão maçante quanto à resolução de uma lista de expressões numéricas: perde a ludicidade. No entanto, resolver uma expressão numérica também pode ser lúdico, dependendo da forma como é conduzido o trabalho. O jogo deve ser jogo do conhecimento, e isto é sinônimo de movimento do conceito e de desenvolvimento. (MOURA, 1992, p. 5)

Os jogos potencializam a aprendizagem e o desenvolvimento, todavia não se pode secundarizar a necessidade da intencionalidade pedagógica e identificação dos objetivos que direcionam as ações dos alunos e do professor nas aulas. A proposta de um jogo para o ensino de conceitos matemáticos pode ser uma ferramenta a mais no ensino, visto que a matemática deve considera o lúdico, no intuito de motivar, despertar o interesse e o pensar dos alunos. Mas, muitas vezes, ele é o único e fica deslocado de outras ações pedagógicas.

Buscando evitar essa ruptura entre o jogo e as demais ações educativas, partimos da exploração do que a professora já vinha trabalhando em sala, num movimento de continuidade. Resgatamos a literatura que vinha sendo trabalhada nas escolas “As centopeias e seus sapatinhos" de Milton Camargo (2001), publicado pela primeira vez em 1978. Até então a história havia sido contada mostrando as imagens do próprio livro aos alunos. Depois os alunos ilustraram e escreveram uma frase sobre a parte que mais haviam gostado da história. Na matemática, a literatura foi empregada para explorar agrupamento, sendo que cada parte do corpo da centopeia indicava os agrupamentos a serem feitos até que ela fosse completada. Por exemplo, quando o agrupamento solicitado era de dois em dois, as demais partes do seu corpo eram completadas com o 4, 6,8,10 sucessivamente. Depois se solicitava o agrupamento de 3 em 3, 4 em 4 e outros. Entretanto, ao explorar esses agrupamentos, não havia relação com a quantidade de patas da centopeia e nem com o recurso empregado.

Percebemos que o recurso visual utilizado pela professora, não cumpria seu papel de auxiliar no raciocínio e compreensão, pois quando se solicitava agrupamento de 2 os alunos poderiam associar ao número de patas do animal e realizar o solicitado com certo apoio no recurso. No entanto, quando se solicitava que o agrupar fosse de 3 em 3 o recurso não auxiliava na compreensão, por não ter relação com nada expresso no recurso, ou seja, não existia nada de 3, ou 4 nas partes da centopeia. Então, porque a centopeia? Por que a produção desse recurso visual para as aulas?

O fato do segmento do corpo da centopeia não representar relação com a tarefa de agrupar impediu as possíveis contribuições que o material visual pudesse trazer a aprendizagem dos alunos. Leontiev (1983, p. 213, tradução nossa) afirma que é preciso ver no material visual "o que constituirá o objeto da consciência". Sendo assim, ao solicitar agrupamentos diferentes do número 2, a centopeia não estaria favorecendo o raciocínio e a conscientização do conceito, ou seja, teria ficado descontextualizado no processo, sem sentido e significado quando pensamos no conceito em questão.

Mas, percebemos que os alunos demonstraram interesse pela história e demonstraram não terem compreendido o que seria agrupar. Durante os encontros formativos do Pibid avaliamos o trabalho feito a fim de identificarmos possibilidades de avançar nas intervenções didáticas objetivando promover a 
aprendizagem. Iniciamos nossa intervenção explorando a história e o trabalho feito pela professora regente. Produzimos, um poema relacionando a história da centopeia com a necessidade de agrupar, expressa em forma de situação-problema a ser solucionada pelos alunos.

Organizamos os alunos sentados em semicírculo na sala de aula de modo que estivessem próximos do material que seria utilizado na leitura do poema. Realizamos a leitura tendo como recurso uma centopeia de pelúcia e alguns sapatos feitos de EVA que poderiam ser colocados nas patas da centopeia, no intuito transformar o concreto, no concreto pensado. Depois da leitura, fomentamos o levantamento de hipóteses para a solução da situação proposta "Vamos ajudar Dona Centopeia, a saber, quantas tampinhas gastará, para essa quantidade de sapatos comprar?". Disponibilizamos aos alunos para auxiliar na resolução, uma caixa de tampas variadas que poderiam ser empregadas como material de contagem para que os agrupamentos pudessem ser feitos.

Mesmo com material concreto, os alunos sentiram dificuldades para realizar os agrupamentos. Inicialmente pensavam em fazer um a um, não conseguiam generalizar. Pensavam em resolver o problema de forma em partes isoladas, não conseguiam fazer o controle geral de quantidades, por exemplo, contavam 6 tampinhas depois a cada novo agrupamento contavam novamente o 6, sem conservar o que já tinham contado.

Trabalhamos a fim de que com o decorrer das intervenções os alunos encontrassem outras estratégias mais eficientes para agrupar. Ao invés de realizarem as compras separadamente, concluíram que se organizassem as tampinhas em grupos a contagem ficaria mais rápida e correta.

Percebemos que após os alunos reconhecerem as vantagens de agrupar ainda não compreendiam como realiza-los. Elaboramos um jogo de tabuleiro em que deveriam agrupar, intitulado "Calçando a Centopeia". O objetivo era "calçar" primeiro a centopeia realizando os agrupamentos, sendo que cada lado da centopeia era de um jogador. Assim, lançava-se o dado, o número que saísse no dado era trocado por palitos, A cada seis palitos adquiridos o jogador poderia trocar por um sapatinho. A cada grupo de seis, um sapato era conquistado. Quem calcasse primeiro seu lado do animal seria o vencedor.

Figura 1: Tabuleiro do jogo

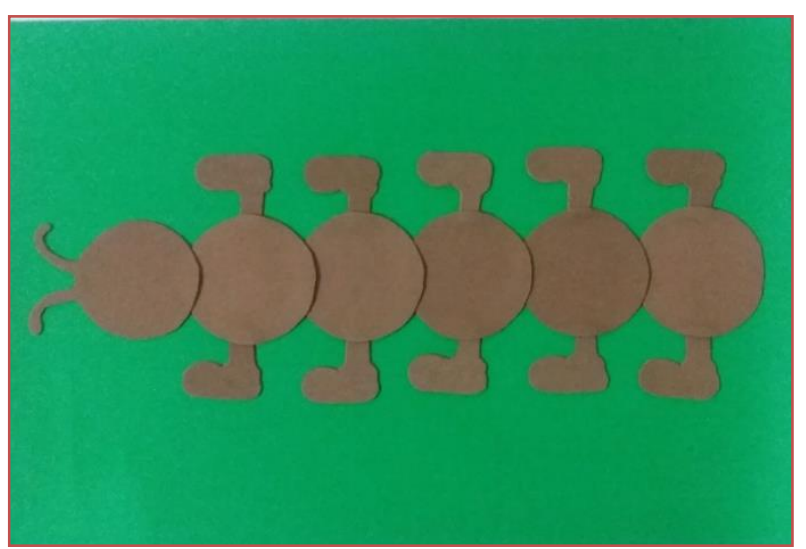

Fonte: Arquivo pessoal dos autores.

Ao trabalhar o jogo em sala de aula, seguimos as orientações didáticas propostas por Lacanallo (2011) a fim de que esse possibilitasse a aprendizagem e o desenvolvimento dos alunos. Destinamos um momento para que os alunos explorassem os materiais, ou seja, que brincassem com o recurso. Em seguida, explicamos as regras buscando mobilizar o desenvolvimento de estratégias para o jogo, criando condições para que os alunos conseguissem os sapatos para calçar a centopeia. Esse momento, "indica o quanto o direcionamento e a intencionalidade são determinantes na formação do pensamento teórico nos alunos no contexto escolar, por meio desse recurso metodológico" (LACANALLO, 2011, p.134).

Inicialmente, os alunos ficavam a todo o momento contando de um a um, com o decorrer das jogadas passaram a separar os palitos de dois em dois, outros de três em três, realizando os grupos com mais eficiência e rapidez. Quando compreenderem que o seis poderia ser contado com grupos menores de 2, 3 e até 5 , alteramos a base 6 para outras possibilidades de trocas. Essas mudanças são estratégias que o 
professor pode empregar para complexificar o trabalho com os conceitos a fim de que esses possam ser generalizados pelos alunos.

Mas, essa evolução na forma de jogar foi paulatina. As situações vivenciadas no jogo apontaram a necessidade do controle de quantidades. Moura et al (2010) alerta que o jogo deve aproximar os alunos das necessidades vivenciadas pela humanidade, pois só assim o recurso será um aliado do ensino da matemática. Quando o aluno reconhece que jogar é algo que está além da descontração, forma-se um pensamento mais reflexivo e argumentativo, desde a compreensão das regras até o modo de agrupar os palitos para obter os sapatos da centopeia torna-se atos pensados sendo indicativos de entendimento e propósitos definidos.

\section{CONSIDERAÇÕES FINAIS}

0 presente relato objetivou apresentar um dos trabalhos desenvolvidos no Pibid/Pedagogia-UEM foco matemática nos Anos Iniciais do Ensino Fundamental. A intervenção pedagógica aqui relatada, despertou nossa atenção pelo movimento que viabilizou entre os acadêmicos e os alunos da escola básica. A partir da proposta feita aos pibidianos pela equipe pedagógica das escolas que recebem o Pibid, o conteúdo a ser desenvolvido foi o agrupamento.

Os pressupostos apresentados nesse trabalho (Teoria Histórico-cultural, Teoria da Atividade e Atividade Orientadora de Ensino) são os que norteiam as ações para a elaboração das intervenções pedagógicas. Moura (2010, p. 221) afirma que na AOE é um "modo geral de organização do ensino, em que seu conteúdo principal é o conhecimento teórico e seu objeto é a constituição do pensamento teórico do individuo". Tendo esse pressuposto, elaboramos Situações Desencadeadoras de Aprendizagem.

A primeira situação desencadeadora de aprendizagem, exploramos a história e o trabalho feito pela professora regente. Elaboramos, um poema relacionando a história da centopeia com a necessidade de agrupar, expressa em forma de situação-problema a ser solucionada pelos alunos. Em um movimento de buscar aprimorar do trabalho já realizado, pois em momentos formativos na universidade ao relatarmos como ocorreu a intervenção pedagógica, identificamos pontos a serem melhorados e uma outra linguagem da qual o aluno poderia se apropriar do conceito.

São momentos de estudos como esses que proporcionam à práxis do docente, em que refletimos o que havíamos feito, e repesamos a nossa intervenção pedagógica. 0 Pibid vem como aliando na formação inicial do professor, em que não ocorre apenas a elaboração de uma intervenção, pronta e acabada. Nosso grupo está em movimento de repensar as atividades elaboradas, a fim de que as mesas ocorram de modo sistematizado e com intencionalidade. Sendo assim, o professor em formação tem a oportunidade de aplicar, discutir em grupo os encaminhamentos, reaplicar, analisar os resultados e assim por diante. Com o intuído que sua prática leve a aprendizagem dos conceitos científicos.

\section{REFERÊNCIAS}

[1] BOGOYAVLENSKY, D. N.; MENCHINSKAYA, N. A. Relação entre aprendizagem e desenvolvimento psicointelectual da criança em idade escolar. In. LEONTIEV, A., VIGOTSKY, L. S., LURIA, A.R. e outros. Psicologia e Pedagogia. São Paulo: Editora Moraes, 2005. p. 63-85.

[2] CAPES. Pibid - Programa Institucional de Bolsas de Iniciação à Docência. Disponível em: http://www.capes.gov.br/educacao-basica/capesPibid. Acesso em: 11 de Mai. de 2017.

[3] ELKONIN, Daniil B. Psicologia do jogo; tradução Álvaro Cabral. - São Paulo: Martins Fontes, 1998.

[4] INEP. Instituto Nacional de Estudos e Pesquisa Anísio Teixeira. Prova Brasil. Brasília: 2007. Disponível em: <http://provabrasil.inep.gov.br >.

[5] INSTITUTO NACIONAL DE ESTUDOS E PESQUISAS EDUCACIONAIS. Informe de resultados do SAEB 1995, 1997 e 1999. Brasília, DF: Ministério da Educação, 2002.

[6] InSTITUTO NACIONAL DE ESTUDOS E PESQUISAS EDUCACIONAIS. Relatório Nacional do Pisa, 2000. Brasília, DF: Ministério da Educação, 2001.

[7] LEONTIEV, A. N. Actividad, conciencia, personaidad. Tradução Librada Leyva Soler, Rosario Bilbao Crespo e Jorge C. Potrony Garcia. La Habana: Pueblo y Educación, 1983.

[8] CAMARGO, M. As centopéias e seus sapatinhos. Editora Ática, 2001. 
[9] _. Sobre o desenvolvimento histórico da consciência. In: . O desenvolvimento do psiquismo. Tradução Rubens Eduardo Frias. 2. ed. São Paulo: Centauro, 2004. p. 95-152.

[10] _. Uma contribuição à teoria do desenvolvimento da psique infantil. In: VYGOTSKY, L. S.; LURIA, A.; LEONTIEV, A. N. Linguagem, desenvolvimento e aprendizagem. Tradução Maria da Penha Villalobos. 10. ed. São Paulo: Ícone, 2006. p. 59- 83.

[11] LACANALLO, L. F. O jogo no ensino da matemática: contribuições para o desenvolvimento do pensamento teórico. 221 f. Tese (Doutorado em Educação) - Universidade Estadual de Maringá. Maringá, 2011.

[12] MOURA, M.O. et. al.. Atividade Orientadora de Ensino: unidade entre ensino e aprendizagem. Diálogos Educacionais. Curitiba, v. 10, n. 29, p. 205-229, jan./abr. 2010

[13] MOURA, M. O. 0 jogo e a construção do conhecimento matemático. Série Idéias n. 10, São Paulo: FDE, 1992.p. 45-52

$[14]$ Paulo, 1996.

. (Coord.). Controle da variação de quantidades: atividades de ensino. São Paulo, Universidade de São

[15] _. A A atividade de ensino como ação formadora. In: CASTRO, A. D.; CARVALHO, A. M. P. de. (Org.). Ensinar a ensinar: didática para a escola fundamental e média. São Paulo: Pioneira Thompson, 2002. 


\section{Capítulo 2}

O PIBID de matemática numa escola pública de Natal/RN: Perspectivas metodológicas dentro e fora da sala de aula

\section{Querem Apuque Felix de Andrade Marinho \\ Pérola Diana Gomes Felipe \\ Mirella Ingrid Oliveira da Cruz. \\ Valdeniz da Silva Cruz Junior}

Resumo: Este trabalho abrange atividades desenvolvidas e em desenvolvimento, desencadeadas pelo PIBID de Matemática da UFRN, em uma instituição pública de ensino básico - E.E. Instituto Ary Parreiras (Natal/RN). Em consonância com os objetivos deste programa, lançamos mão de ações e propostas diretivas e integrativas que atendam às necessidades e expectativas dessa comunidade escolar, em especial, discentes de cinco turmas de 6ํㅜ Ano do Ensino Fundamental Anos Finais. Tivemos como objetivos promover uma melhoria na qualidade de ensino da Matemática aos educandos de forma a tangenciar uma concepção de sujeito ativo em seu processo de aprendizagem. Pautadas na crescente presença da Matemática nas situações cotidianas e nos novos desafios trazidos aos licenciandos, quanto à necessidade de práticas de abordagens de ensino que busquem motivar os alunos a participarem das aulas e se reconhecerem como sujeitos críticos da realidade que os rodeiam, nossas sugestões de atuação contemplam ações dentro e fora da sala de aula. Tais ações visam, também, à inserção dos licenciandos no cotidiano da escola e são elas: aulas de iniciação à docência; apoio didático, pedagógico e metodológico em sala; atividades de intervalo e culminância final. As intervenções realizadas nesse âmbito têm permitido aos discentes estabelecerem conexões entre os conteúdos matemáticos e ações diárias práticas, possibilitando que, por meio de trabalhos concretos, possam entrar, de fato, no mundo abstrato da Matemática.

Palavras-chave: PIBID, Matemática, Educação. 


\section{INTRODUÇÃO}

Rolim (2014) afirma que o caminho para se atingir a efetividade do processo de ensino-aprendizagem, passa, efetivamente, por um movimento conjunto de diversos entes da sociedade, existindo assim, a colaboração das escolas, das entidades governamentais e da comunidade. Nesse sentido, Programa Institucional de Bolsa de Iniciação à Docência (PIBID) desenvolve-se em um regime de colaboração entre a Coordenação de Aperfeiçoamento de Pessoal de Nível Superior (Capes); os Estados, o Distrito Federal e os Municípios, por meio de suas Secretarias de Educação ou órgão equivalente; e as Instituições de Ensino Superior (IES) selecionadas e homologadas no edital do Programa e inclui atividades nas dependências das Universidades Federais e nas escolas públicas participantes do Programa.

Ribnikov (1987) destaca que se os conteúdos da Matemática forem ensinados de forma desagregada de situações contextualizadas, eles tornam-se conhecimentos superficiais e desinteressantes para os alunos. Nos Parâmetros Nacionais da Educação, a melhoria no processo de ensino-aprendizagem da Educação Matemática é trazida como um tema que está sendo frequentemente discutido tanto no Brasil, quanto em outros países, uma vez que essa ciência está presente em diversas atividades do saber humano (BRASIL, 1998). Complementado a abordagem de Ribnikov, na Base Nacional Comum Curricular (BNCC) o conhecimento matemático é apontado como necessário para todos os alunos da Educação Básica, seja por sua grande aplicação na sociedade contemporânea, seja pelas suas potencialidades na formação de cidadãos críticos, cientes de suas responsabilidades sociais (Brasil, 2018). Desta forma, é possível afirma que o ensino da Matemática passa a excluir o aluno como sujeito agente do processo ensino-aprendizagem quando não se leva em conta uma articulação do saber matemático ensinado com sua vivência.

Estabelecido como um dos seus objetivos, Programa Institucional de Bolsa de Iniciação à Docência (PIBID/UFRN) prever a inserção os licenciandos no cotidiano de escolas da rede pública de educação, proporcionando-lhes oportunidades de criação e participação em experiências metodológicas, tecnológicas e práticas docentes de caráter inovador e interdisciplinar que busquem a superação de problemas identificados no processo de ensino-aprendizagem; o incentivo às escolas públicas de educação básica, mobilizando seus professores como formadores dos futuros docentes e tornando-as protagonistas nos processos de formação inicial para o magistério e a contribuição para a articulação entre teoria e prática necessárias à formação dos docentes, elevando a qualidade das ações acadêmicas nos cursos de licenciatura. Inserido nesse cenário e tomando como base as fundamentações estabelecidas até aqui, o presente trabalho abrange atividades desenvolvidas e em desenvolvimento desencadeadas pelo PIBID de Matemática da Universidade Federal do Rio Grande do Norte (UFRN), em uma instituição pública de ensino básico - E.E. Instituto Ary Parreiras (Natal/RN).

A equipe, que atua na instituição pública de ensino básico objeto do estudo, é constituída por 01 coordenador do programa, 01 supervisor, 09 licenciandos e Matemática. Dos 09 licenciandos atuantes, 08 são bolsistas e 01 voluntário. 0 supervisor da equipe é professor titular de Matemática dos cinco 6 o anos do ensino fundamental anos finais do turno matutino da referida escola. Sendo essas as turmas em que atuam os bolsistas locados nessa escola.

Nossas sugestões de atuação, enquanto bolsistas de iniciação à docência, junto ao supervisor da escola e sob orientação de nossa coordenação do programa, contemplam ações em sala de aula e fora dela, a saber: aulas de iniciação à docência; apoio didático; pedagógico e metodológico em sala; atividades de intervalo e culminância final das ações. Tais ações foram pensadas e discutidas, quando ao seu planejamento e execução, em reuniões quinzenais com a participação do supervisor e de todos os bolsistas, como bem elaboramos e analisadas estratégias de atuação direta dos bolsistas de acordo com o plano anual do professor supervisor.

Aqui, traremos a descrição dessas ações, em função não só da atuação dos bolsistas do programa em relação à inserção desses no cotidiano da escola e de suas experiências metodológicas e práticas de ensino, como também sua interferência e benefícios para a comunidade escolar como um todo, em termos de discentes, funcionários e professores. Mediante isso, o texto que se segue será organizado de forma a, primeiro apresentar as ações em sala de aula e fora dela, em função do planejamento, execução e uma posterior discursão sobre os resultados dessas. 


\section{AS AÇõES DESENVOLVIDAS DENTRO E FORA DA SALA DE AULA}

\subsection{REUNIÕES DE PLANEJAMENTO}

Todas as ações desenvolvidas na Escola Estadual Instituto Ary Parreiras, foram pensadas e planejadas quanto sua finalidade e execução. 0 planejamento dessas se deu em reuniões quinzenais, com a presença do supervisor e de todos os 09 licenciandos envolvidos no projeto em atuação na referida escola.

Na oportunidade da primeira reunião de planejamento, em 30 de agosto de 2018, os licenciandos foram divididos em 03 duplas e 01 trio, a cada grupo formado foi destinado um dos $6^{0}$ anos do ensino fundamental. Estabeleceram-se também os horários de atuação desses junto à escola e os moldes dessa atuação tendo em vista as aulas de iniciação à docência e de apoio.

Nesses encontros quinzenais, que acontecem nas dependências do Laboratório de Ensino de Matemática da UFRN, a participação dos licenciandos envolvidos no projeto é extremamente ativa. Esses apontam sugestões, iniciativas e estratégias para o desenvolvimento do projeto, de modo que essa atuação esteja de acordo com plano anual do professor supervisor, pondo-as em prática semanalmente nas aulas letivas, no caso das aulas do e mensalmente, no caso das aulas de iniciação a docência, tratando-se também das atividades de intervalo, assim como, da culminância semestral das ações.

Ainda nesses momentos, as tarefas referente a cada atividade são delegadas aos membros do grupo pelo supervisor, são formulados planos de aula para atuação da iniciação à docências, realizados feedbacks entre supervisor e bolsistas e expostas as dificuldades e aprendizado de cada um quanto as práticas metodológicas e pedagógicas empregadas, de modo a contribuir para a articulação entre teoria e prática necessárias à formação dos docentes, elevando a qualidade das ações acadêmicas nos cursos de licenciatura, conforme estabelecido como um dos objetivos do programa (Brasil, 2018).

\subsection{AULAS DE APOIO}

Sendo como um dos objetivos do PIBID, trazer e inseri os licenciandos no cotidiano de escolas da rede pública de educação e em sua realidade, a fim de proporcionando-lhes oportunidades frente ás experiências e metodológicas, tecnológicas, de modo que esses, ao serem inseridos, possam elevar a qualidade da formação da sua formação promovam a integração entre educação superior e educação básica, tal ação foi inserida nesse projeto.

As aulas de apoio, como já expressa a sua nomenclatura, englobam ricas e oportunas experiências, vivenciadas semanalmente, nas aulas ministradas pelo professor supervisor, em que os bolsistas lhe prestam auxílio seja como monitores seja como agentes executores de ações afins. 0 suporte dado durante tais aulas comporta ações de assistência individualizada aos discentes, no tocante ao esclarecimento de duvidas e auxilio na resolução de exercícios; correções de atividades na lousa, auxílio na execução de atividades práticas diferenciadas, além das observações quanto à dinâmica das aulas, objetivando o aprendizado da prática docente.

Como exemplo de ações de assistência individualizada aos discentes, os bolsistas Mirella Ingrid e Valdeniz da Silva, atuantes no $6^{\circ}$ ano $\mathrm{C}$, se voluntariaram a prestar esse tipo de assistência a uma discente da referida turma. Essa discente possui certa dificuldade de aprendizagem, ainda não diagnosticada, mas que a impede de acompanhar, em muitas situações, o desenvolvimento da turma, além de apresentar alguma dificuldade motora e de dicção.

A ação de apoio foi realizada com intuito de verificar se a discente em questão possuía noções de quantidade, sequência numérica e diferenciação de cores. Essa ação se deu no pátio da escola, durante o momento que a mesma esperava a chegada dos pais, sendo supervisionada pelo professor supervisor.

\subsection{AULAS DE INICIAÇÃO A DOCÊNCIA}

De forma a corroborar com os objetivos do Programa Institucional de Bolsa de Iniciação à Docência, as aulas de iniciação a docência correspondem à atuação direta dos bolsistas ao desempenharem a função de professores em sala de aula, sempre sob a supervisão do professor supervisor, contribuindo também para a articulação entre teoria e prática necessárias à formação dos docentes, elevando a qualidade das ações acadêmicas nos cursos de licenciatura.

Nesse sentido, as ações desenvolvidas pelo grupo no tocante a essas aulas, ocorreram em dois momentos e abordaram diferentes conteúdos do plano anual do professor supervisor. As referidas aulas tiveram 
duração de 80 minutos e formam ministradas pelos bolsistas, com supervisão do professor supervisor e, quando necessário, algumas interferências feitas por esse.

Na primeira dessas aulas, conforme solicitação do professor supervisor, foi abordado o conteúdo introdutório a respeito de frações, relacionado a ideia de parte e todo, além da compreensão do conceito de fração como representatividade numérica. Para a realização das ações aqui tratadas, cada grupo $(03$ duplas e 01 trio) elaborou um plano de aula e estabeleceu os materiais e/ou recursos didáticos utilizados na atividade, além do processo de avalição que seria estabelecido. Como recurso didático, os grupos optaram trabalhar como o um material manipulativo, escolhendo todos, por coincidência, os Discos de frações. A Figura 04 mostra a aplicação desse recurso no decorrer da aula, podendo-se observa a postura dos alunos frente à atividade proposta, bem como a disponibilidade do bolsista para com esses. No Apêndice A, encontra-se um exemplo do plano de aula desenvolvido por um dos grupos, com a descrição das aulas e atividades desenvolvidas no decorrer dessas.

Na segunda aula de iniciação à docência foram trazidos como enfoque diferentes conteúdos matemáticos: ângulos e retas; polígonos e formas circulares. Aqui, o plano de aula, para tal atuação, foi realizado em conjunto com todos os bolsistas, bem como todas as ações propostas para o desenvolvimento da aula. Tomando como base a ótica de Lara (2003) sobre o uso dos jogos como recurso de aprendizagem, que admite ser possível além da possibilidade da aprendizagem derivada do concreto ao abstrato, o jogo permite e estimula a interação entre os seus participantes, optou-se pela aplicação do "Jogo da identificação" nessa segunda experiência de iniciação à docência.

\section{RESULTADOS}

As ações de apoio realizadas no decorrer da atuação do programa permitiram aos bolsistas à oportunidade de estabelecer uma aproximação com os alunos assistidos e, mediante a isso, elaborar e desenvolver atividades que vissem ao encontro das suas dificuldades de aprendizagem.

Quanto aos alunos, esses perceberam a disponibilidade dos bolsistas e os agregaram ao seu cotidiano escolar, procurando-os para sanar dúvidas e para discutir questões não só dos conteúdos trazidos nas aulas de matemática.

As aulas de Iniciação à docência, quanto aos bolsistas, corroborando com os objetivos estabelecidos no edital do PIBID, não só inseriu tais participantes na realidade e cotidiano da escola, como contribui para sua participação nas metodológicas, tecnológicas e práticas docentes de caráter inovador e interdisciplinar, em função do planejamento, elaboração e execução das aulas, bem como a produção de planos de aula e de jogos didáticos, além da aplicação desses jogos e materiais didáticos manipulativos.

Quanto aos alunos, em relação à primeira aula de iniciação a docência, percebeu-se que a aplicação dos Discos de frações como material manipulável, levou esses a uma maior compreensão da ideia de parte e todo, percepção que foram confirmadas no momento da correção em lousa das atividades propostas. Foi observado ainda, que assuntos correlatos ao conteúdo de frações, expostas posteriormente a essa aula, foram compreendidos pelas turmas com maior facilidade.

A segunda dessas aulas mostrou resultados bem ambíguos. No primeiro momento, em que os conceitos foram trazidos de maneira expositiva, os alunos inicialmente demostraram interesse, entretanto, como o passar de um curto espaço de tempo, alguns se dispersaram e perderam o interesse inicial. No segundo momento, quando se lançou mão do "Jogo da identificação", esses se mostram muito participativos e competitivos, buscando ganhar o jogo.

Aqui, foi possível observar que a elaboração e execução de uma aula apenas expositiva, para alunos do 6o ano do ensino fundamental ano finais, pode leva-los a perda do interesse pelo que se expõe, sendo aconselhável introduzir, no decorrer das atividades, algo que posso ser compatível com a ludicidade que ainda acompanha alunos na faixa etária atendida por tais turmas (entre 11 e 13 anos). Ao analisar o objeto de avaliação da referida aula, foi possível verificar uma assimilação muito satisfatória do conteúdo por parte dos alunos. Das 10 questões propostas na lista de exercícios, mais de $80 \%$ das turmas apresentaram acima de 08 acertos.

A atividade de intervalo mobilizou toda a escola. Alunos de todas as turmas e de todos os turnos participaram deixando na urna respostas aos desafios, muitos funcionários se ariscaram em respostas, ainda que não oficiais. A participação semanal média nessa atividade foi de 150 alunos. Dessas 150 participações, em média 30 apontaram respostas compatíveis com as sugestões expostas a posteriori no 
mural. Esse resultado foi tomado como positivo, pois os desafios trazidos aqui não eram tão simples de serem resolvidos.

\section{CONCLUSÃO}

A relevância de tal experiência deu-se não somente no tocante ao aprendizado e amadurecimento em função de práticas pedagógicas e docentes, dos bolsistas envolvidos no projeto, como também ao desenvolvimento dos alunos em relações os conteúdos tratados.

Percebeu-se que, presença do PIBID/UFRN de matemática, na pessoa dos seus bolsistas, trouxe a escola um novo aspecto educacional em relação as aulas de matemática, ficando isso evidenciado na absorção clara dos conteúdos pelos discentes, além da aceitação, por parte de toda essa comunidade escolar, das provas estabelecidas para fazer parte de um evento tradicional da escola.

\section{REFERÊNCIAS}

[1] BRASIL. Secretaria de Educação Fundamental. Parâmetros Curriculares Nacionais: Matemática. Brasília: MEC, SEF, 1998. 148 p. Disponível em: <http://portal.mec.gov.br/seb/arquivos/pdf/matematica.pdf>. Acesso em: 11 out. 2018.

[2] BRASIL. Ministério da Educação. CAPES. Coordenação de Aperfeiçoamento de Pessoal de Nível Superior Programa Institucional de Bolsa de Iniciação à Docência - PIBID Chamada Pública para apresentação de Propostas EDITAL № 7/2018. Disponível em:< http://www.capes.gov.br/sala-de-imprensa/noticias/8778-capes-publicaeditais-do-pibid e-do-novo-programa-de-residencia-pedagogica>. Acesso em: 11 out. 2018.

[3] LARA, Isabel Cristina Machado de. Jogando com a Matemática. - 1.ed - São Paulo: Rêspel, 2003.

[4] ROLIM, C. L. A. Cursos de pedagogia: desafios e perspectivas para o ensino da Matemática. Rev. Fac. Educ. , v. 21, ano 12, n. 1, p. 83-98, jan./jun. 2014. Disponível em: <http://www2.unemat.br/revistafaed/content/vol/vol_21/artigo_21/83_98.pdf>. Acesso em: 11out. 2018.

[5] RIBNIKOV, K. Historia de las matemáticas . Moscou: Editorial Mir, 1987. 244 p. Disponível em: <https://pt.scribd.com/doc/181450824/K-Ribnikov-Historia-de-las-Matematicas>. Acesso em: 12 out. 2018. 


\section{APÊNDICES}

Apêndice A - Plano de aula de iniciação à docência

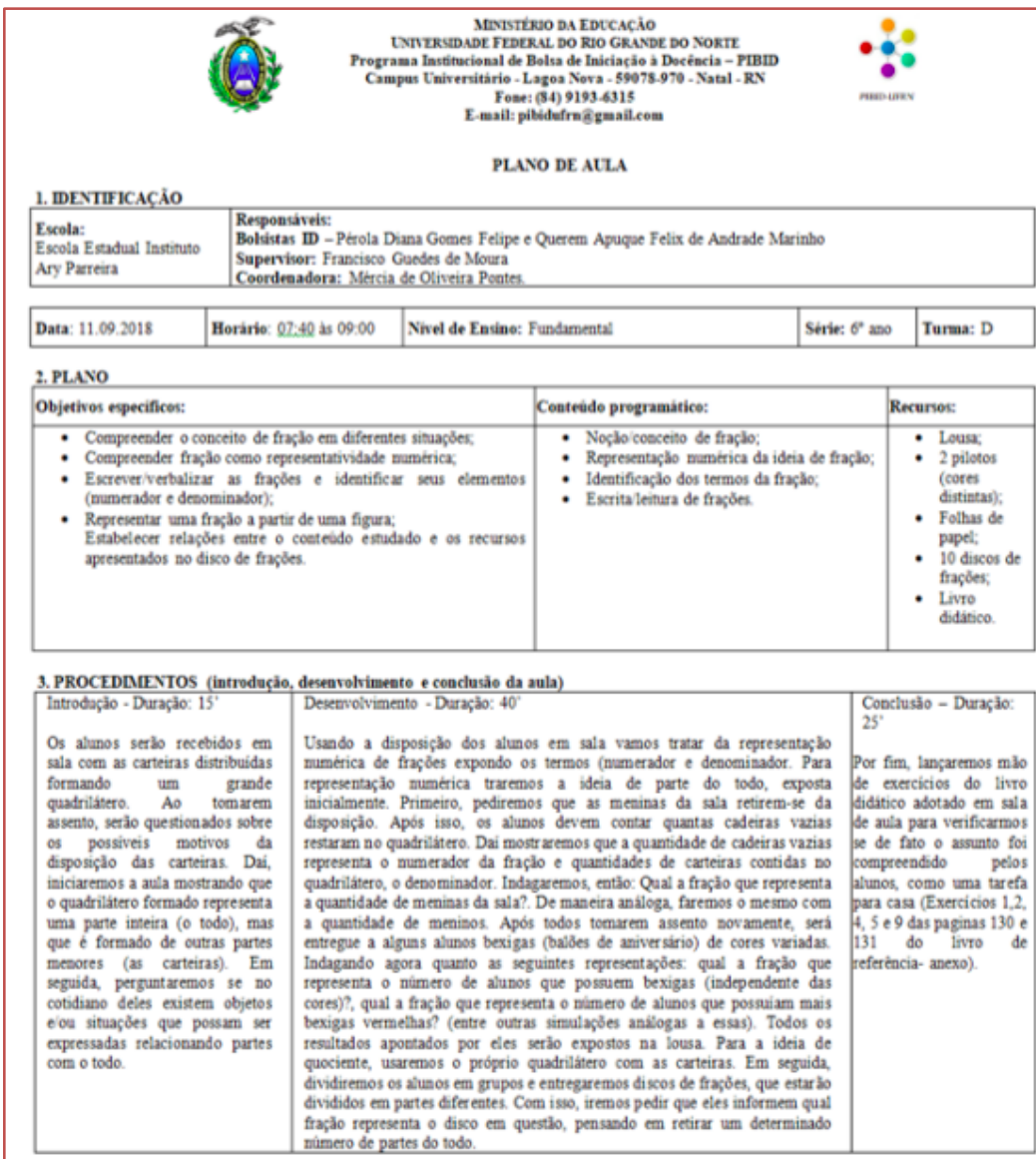

4. AVALLCĊ̃o

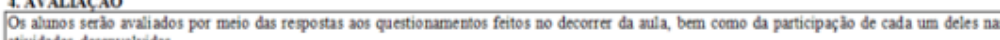
atividades deseavolinides

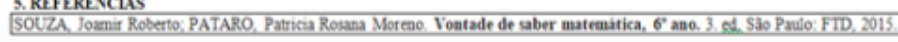




\section{Capítulo 3}

\section{Educação moral na escola: O trabalho do PIBID de psicologia com o ensino médio}

\section{Priscila Vargas Gatti \\ Jaqueline Batista de Oliveira Costa}

Resumo: 0 objetivo desse trabalho, inicialmente apresentado no XII Congresso Nacional de Educação (EDUCERE), consiste em relatar a experiência de bolsistas do Programa Institucional de Bolsa de Iniciação à Docência (PIBID) do curso de Psicologia da Universidade Federal da Grande Dourados (UFGD) na realização de um trabalho sobre Ética e Moralidade com alunos de ensino médio de uma escola estadual localizada na cidade de Dourados, no estado do Mato Grosso do Sul. Inicialmente, analisamos o que os alunos já sabiam sobre o assunto, com base em conversas e discussões realizadas durante uma roda de conversa. Em seguida, realizamos algumas dinâmicas de grupo e levantamos discussões, subsidiadas pelos teóricos que discutem sobre o tema. Além disso, procuramos fazer aulas didáticas, com auxilio de recursos audiovisuais, que tornassem os encontros mais interessantes. Por fim, realizamos uma nova roda de conversa cuja finalidade foi saber o que os alunos acharam dos encontros e se os ajudou. Essas atividades tiveram como objetivo identificar o que os alunos sabiam sobre temas como: Ética, Moral, Conduta, Respeito Mútuo, Justiça, Preconceito, entre outros conceitos relacionados à moralidade. Além disso, buscamos auxiliar os alunos a ampliarem seus conhecimentos sobre esses assuntos. Os resultados mostraram que os alunos conheciam pouco sobre os temas trabalhados e que as dinâmicas de grupo e as discussões decorrentes os auxiliaram a obter maior compreensão sobre os assuntos e constituíramse como excelentes estratégias na promoção de aprendizagens significativas. Esse trabalho se faz importante na medida em que está de acordo com as propostas previstas nos Parâmetros Curriculares Nacionais para o ensino médio e para a educação básica em geral, trabalhando com temas transversais e emergentes. Além disso, buscamos contribuir para a discussão a respeito da reinserção da disciplina de Psicologia no ensino médio. 


\section{INTRODUÇÃO}

De acordo com a Coordenação de Aperfeiçoamento de Pessoal de Nível Superior (CAPES), um dos objetivos do Programa Institucional de Bolsa de Iniciação à Docência (PIBID) é incentivar à carreira docente na educação básica, contribuindo para a valorização do magistério (BRASIL, 2010).

O subprojeto do PIBID de Psicologia, consoante com os objetivos do PIBID, busca incentivar a formação em nível superior de docentes para atuarem na educação básica, objetivando valorizar o magistério. Vale mencionar ainda que, com o PIBID, busca-se a superação dos problemas que são encontrados no processo de ensino-aprendizagem (BRASIL, 2010).

Para tanto, são trabalhados os chamados temas transversais, elaborados em consonância com os Parâmetros Curriculares Nacionais (PCNs) e também a partir de questões sociais emergentes. Podemos destacar, conforme versam os Parâmetros (BRASIL, 1997), os seguintes temas transversais: Ética, Saúde, Orientação Sexual, Meio Ambiente, Trabalho e Consumo e Pluralidade Cultural.

Nosso objetivo é investigar se alunos de uma turma de 3o ano do ensino médio de uma escola pública compreendem os conceitos relacionados à Ética e Moralidade. Além disso, buscamos auxiliar na construção de um repertório de conhecimentos mais amplo no que diz respeito a comportamentos morais.

\section{A FORMAÇÃO ÉTICA COMO OBJETIVO DA EDUCAÇÃO BÁSICA}

De acordo com as Diretrizes Curriculares Nacionais da Educação Básica (2013, p.39), o Ensino Médio, que terá duração de três anos, tem por finalidades:

I - a consolidação e o aprofundamento dos conhecimentos adquiridos no ensino fundamental, possibilitando o prosseguimento de estudos; II - a preparação básica para o trabalho e a cidadania do educando, para continuar aprendendo, de modo a ser capaz de se adaptar com flexibilidade a novas condições de ocupação ou aperfeiçoamento posteriores; III - o aprimoramento do educando como pessoa humana, incluindo a formação ética e o desenvolvimento da autonomia intelectual e do pensamento crítico; IV - a compreensão dos fundamentos científicotecnológicos dos processos produtivos, relacionando a teoria com a prática, no ensino de cada disciplina.

Como podemos observar, uma das finalidades do Ensino Médio, é "a formação ética e o desenvolvimento da autonomia intelectual e do pensamento crítico" (BRASIL, 2013, p. 39).

Essa formação ética deve iniciar-se desde o ingresso dos alunos no universo escolar. Afinal, os valores éticos são internalizados por meio da convivência familiar, social e escolar. Diante disso, podemos perceber a importância do trabalho realizado pelo PIBID de Psicologia, na medida em que contribui para a formação ética dos alunos.

\section{CONTRIBUIÇÕES DA PSICOLOGIA PARA A FORMAÇÃo ÉTICA}

Como sabemos, a Psicologia não está presente nos Parâmetros Curriculares Nacionais. No entanto, é preciso que a escola trate de questões que interferem na vida dos alunos. Afinal, essas questões interferem também no processo de ensino-aprendizado. Os temas transversais podem e devem ser tratados em todas as disciplinas, incorporados na matéria (BRASIL, 1997).

O trabalho das temáticas propostas pelos PCNs visa, dentre outros propósitos, contribuir para a formação integral dos estudantes, formação esta que contemple a dimensão moral necessária para a construção da autonomia e de competências básicas para o exercício da cidadania, como pedem os Parâmetros Curriculares Nacionais do Ensino Médio (BRASIL, 2000).

Dessa forma, a Psicologia pode contribuir com a aprendizagem e a transformação do cotidiano escolar, trabalhando com os temas que interferem, direta ou indiretamente, no cotidiano dos alunos. Com isso, a educação básica assume uma postura interdisciplinar e mais comprometida com a vida em sociedade. Afinal, compreender a cidadania como participação social e política e posicionar-se de forma crítica, responsável e construtiva frente a situações sociais são objetivos a serem alcançados pela educação básica (BRASIL, 1996). 


\section{A ESCOLA COMO FACILITADORA DA FORMAÇÃO ÉTICA E DO DESENVOLVIMENTO MORAL}

Muller e Alencar (2012) afirmam que um dos grandes teóricos da moralidade foi o americano Lawrence Kohlberg, que entendia o desenvolvimento moral como a possibilidade de abandonar uma postura de obediência às autoridades e alcançar uma postura que baseia suas ações em princípios éticos universais legitimados por cada um.

Muller e Alencar (2012) também entendem que a formação moral tem como principal objetivo a formação de sujeitos autônomos, que consigam ver os valores morais como diretrizes internas e não como leis que são impostas. Uma das formas de retratar os valores morais é por meio de ações cooperativas que, de acordo com as autoras, possibilitam que várias pessoas cooperem para alcançar um bem comum. A escola, como um ambiente onde os alunos podem interagir e socializar, se constitui como um meio propício para a realização de ações que valorizem o cooperativismo.

Segundo Araújo (2008, p. 203), a educação de valores se difere da educação em valores. A primeira não contribui para a construção de personalidades autônomas, já que parte de conceitos pré-estabelecidos e modelos autoritários para ensinar. Já a educação em valores, defendida pelo autor, seria aquela que parte dos valores que os alunos já conhecem, devido à convivência em sociedade. Assim, para ensinar, recomenda-se considerar a "complexidade da natureza psicológica do ser humano." Para tanto, é importante que os educadores levem em consideração, na hora de ensinar, a história dos alunos. Afinal, o aluno já vive em sociedade antes mesmo de seu ingresso no sistema educacional.

\section{REORGANIZAÇÃO DAS PRÁTICAS EDUCACIONAIS}

Apesar das considerações feitas a respeito da educação básica, percebemos que as práticas educacionais ainda estão distantes do ideal. De acordo com Araújo (2000), a inadequação dos conteúdos trabalhados nas disciplinas da grade curricular são um dos grandes problemas que a educação brasileira enfrenta, conteúdos esses que são dissociados do cotidiano dos alunos.

Diante disso, como afirma Araújo (2000), as escolas devem ter coragem e desejo político de reorganizar suas estruturas curriculares para formarem sujeitos éticos e personalidades morais, autônomas e críticas. Essa reorganização é papel, também, dos profissionais da educação. Mais uma vez, o PIBID demonstra sua importância, pois procura formar docentes comprometidos e críticos, que se desvencilham dos modelos tradicionais de educação.

Araújo, (2000, p.99) ressalta ainda que não basta apenas reorganizar os conteúdos, é preciso também reorganizar as metodologias de ensino. Os educadores precisam promover estratégias educativas que incorporem três tipos de atividades: Reflexivas, ou seja, atividades que façam com que os alunos reflitam de maneira crítica aspectos da realidade. Essas atividades envolvem, por exemplo, debates, discussões e análises de filmes; Conceituaisconcretas, que podem acontecer por meio de dinâmicas de grupos, nas quais os conceitos sejam experienciados de forma concreta a partir de situações hipotéticas; E, por fim, atividades prático-experienciais que permitem a construção de conhecimentos a partir das próprias experiências sociais (ARAÚJ0, 2000). Dessa forma, os valores morais que, segundo Araújo (2000), não podem ser ensinados assim como também não nascem com as pessoas, são construídos em experiências significativas do sujeito com o mundo.

A teoria piagetiana nos leva a acreditar que a escola compreende um espaço privilegiado para que se reflitam valores morais e condutas. Ninguém nasce com a moral já constituída, mas a escola pode ajudar a construir sujeitos morais, já que permite o contato com iguais e com as diferenças individuais. Ou seja, a escola deve cumprir a missão de estimular o aluno a ver o outro como um individuo com quem se deve colaborar e não rivalizar (OLIVEIRA; CAMINHA; FREITAS, 2010).

A escola precisa criar oportunidades para que os alunos tenham a vivência de valores que nascem nas relações de convivência, nos relacionamentos. Isso não pode ser feito de forma mecânica, ensinando aos alunos os valores morais como regras absolutas. O ideal é que essa atividade seja feita de forma que faça com que os alunos reflitam (OLIVEIRA; CAMINHA; FREITAS, 2010).

\section{A RELAÇÃO ENTRE PSICOLOGIA E ENSINO MÉDIO}

Quando falamos de Psicologia e Ensino Médio, não podemos deixar de mencionar o fato de que a Psicologia já foi uma disciplina prevista nessa etapa da educação, mas que hoje não faz mais parte do currículo nacional do ensino médio. Contudo, considera-se que o aprimoramento do educando como 
pessoa humana, bem como sua formação ética e autônoma, prevista nas Diretrizes Curriculares Nacionais para a Educação Básica, passa, necessariamente, por reflexões que ocorrem no campo da Psicologia. Assim, acredita-se que tanto quanto as disciplinas de Sociologia e Filosofia, o lugar da Psicologia como disciplina curricular, deveria estar garantido nesse nível de ensino (KOHATSU, 2010).

Entretanto, uma questão que merece ser considerada relaciona-se a situação dos cursos de licenciatura em Psicologia. Estes são escassos, e, quando marcam presença no âmbito das graduações, são pouco valorizados. Disso decorre uma formação deficitária dos futuros professores de Psicologia e, como consequência, uma dificuldade em selecionar e organizar conteúdos de ensino de Psicologia para a escola de educação básica (KOHATSU, 2010).

Esse cenário de desvalorização do docente de Psicologia reforça ainda mais a importância do PIBID, que busca valorizar o magistério, formando docentes qualificados e preparados para exercer a profissão.

Kohatsu (2010) afirma ser imprescindível que se conheça a realidade do ensino médio e que se reflita sobre a real contribuição da psicologia para melhorar esse nível da educação nacional. Esse trabalho busca também contribuir para essa discussão, tentando mostrar o quão importante é a presença da Psicologia no Ensino Médio.

\section{TRABALHO DO PIBID COM EDUCAÇÃO MORAL}

Tendo em vista a reflexão acima apresentada, o objetivo desse texto é relatar a experiência de um trabalho realizado pelo PIBID do curso de Psicologia da Universidade Federal da Grande Dourados (UFGD) com os alunos do $3^{\circ}$ ano do ensino médio de uma escola estadual localizada na cidade de Dourados/MS. Primeiramente, objetivou-se identificar o que eles já sabiam sobre os conceitos de Ética e Moral, além de discussões sobre alguns dos valores morais presentes em nossa sociedade como, por exemplo: Companheirismo, Perseverança, Respeito Mútuo e Justiça.

Foram realizados sete encontros ao longo dos meses de agosto, setembro, outubro e novembro de 2014, em horários de aula cedidos por professores. Cada encontro durou uma hora-aula, ou seja, 50 minutos. Utilizou-se de dinâmicas de grupo, além de recursos audiovisuais, para trabalhar de forma dinâmica e atrativa os temas propostos.

No primeiro encontro, como planejado, apresentamos aos alunos, durante uma roda de conversa, os conceitos que seriam trabalhados, para saber quais eram seus conhecimentos prévios sobre os assuntos. Percebeu-se que muitos alunos associavam ética com respeito e/ou educação, outros entendiam a ética como sendo algo aplicado apenas ao contexto de trabalho. Já a moral foi descrita em termos de certo e errado, incluindo leis e valores pessoais. Notou-se ainda que muitos alunos entendiam a Justiça como sendo sinônimo de Vingança, enquanto outros a relacionavam com Igualdade.

No segundo encontro, foram realizadas três dinâmicas de grupo, que objetivaram proporcionar aos estudantes uma compreensão dos conceitos que seriam trabalhados de forma mais prática. A primeira dinâmica de grupo consistia em fazer com que cada aluno, segurando um balão, imaginasse que esse balão era seu maior sonho. Era dito aos alunos que eles teriam cinco minutos de jogo e que aqueles que conseguissem ficar com seus balões inteiros, ganhariam e teriam seus sonhos realizados. Além disso, foi dito aos alunos que eles teriam cinco minutos até o fim da dinâmica de grupo. Ao dar o sinal que marcava o inicio do "jogo", como esperado, todos os alunos partiram em busca de estourar os balões dos colegas. Apesar de termos cinco minutos, a dinâmica de grupo se encerrou com menos de dois minutos, pois todos os balões já haviam sido estourados pelos participantes.

Essa dinâmica de grupo auxiliou nas discussões sobre ética, moral e conduta. Além disso, algumas histórias, verídicas e fictícias, foram contadas aos alunos como forma de elucidar as discussões. Essas histórias serviram para ilustrar atitudes éticas, antiéticas, morais e imorais.

Na segunda dinâmica de grupo, em circulo, cada aluno portava um pedaço de papel e uma caneta. Cada um deveria escrever no papel um desafio para o aluno que estava ao seu lado direito. Após todos terem escrito o desafio no papel, foi dito aos alunos que, na verdade, quem deveria cumprir o desafio era, justamente, o aluno que o escreveu.

Participaram dessa dinâmica de grupo doze alunos e, dos doze desafios propostos, apenas três agradaram os estudantes: "Recitar um verso/poema", "Dizer que me ama" e "Dar um abraço em alguém que você gosta". Os outros desafios envolviam esforço físico e atividades humilhantes. A partir dessa dinâmica de grupo, discutimos os conceitos de respeito mútuo e justiça. É interessante mencionar que os alunos 
entenderam, prontamente, o significado da dinâmica, afirmando que foi errado da parte deles propor desafios humilhantes aos colegas.

Após essas discussões, seguimos para os próximos temas a serem trabalhados: Perseverança e Companheirismo. Para discutir esses assuntos, utilizamos outra dinâmica de grupo: Dispostos em círculo, cada aluno recebeu um balão. Em seguida, escolheram-se alunos, aleatoriamente, para que saíssem da roda e entregassem seus balões para outra pessoa, até que sobrasse apenas uma pessoa com todos os balões. Logo, os outros alunos foram informados que poderiam ajudar o colega a ficar com todos os balões. Sendo assim, discutiuse o companheirismo, já que os alunos se ajudaram, sem se preocupar com um possível vencedor. Além disso, levando em consideração que os alunos tiveram que se esforçar para manter todos os balões com o colega, chegando até mesmo a amarrá-los nas roupas e/ou cabelos, discutiuse também a perseverança.

Dessa forma, partimos para as discussões sobre Preconceito, Discriminação e Bullying, já no terceiro encontro. Iniciamos o encontro com uma roda de conversa onde os alunos poderiam expor situações de bullying que já presenciaram. A roda de conversa serviu, principalmente, para mostrar como o bullying atinge todos os "tipos" de pessoas, magras ou gordas, altas ou baixas. Os alunos pareceram bastante entusiasmados ao perceberem que não importa como as pessoas são para que elas sofram com o preconceito.

Para aprofundar as discussões sobre preconceito, primeiramente, realizou-se uma dinâmica de grupo que objetivava discutir a ideia de pré-conceito. Para isso, foram descritos 13 conjuntos de características de pessoas não reveladas. Cada aluno deveria escolher cinco dessas pessoas para que fossem com elas para um abrigo subterrâneo em um suposto "fim do mundo" causado por uma catástrofe nuclear.

Depois que os alunos escolheram seus cinco companheiros, baseados em valores como ser homem, mulher, rico, pobre, solteiro ou casado, inteligente ou não, entre outros, eram reveladas as personalidades por trás daquelas características. E, para a surpresa dos alunos, as personalidades que mais receberam votos foram: Hitler, descrito como "estudioso, não fuma e nem bebe, solteiro, grande organizador" e Osama Bin Laden, descrito como um "moço tímido na adolescência, foi soldado e trabalhador voluntário, filho de aristocratas, teve educação esmerada, engenheiro civil, empresário bem-sucedido". As outras personalidades eram: Platão, Martin Luther King, Jesus, Beethoven, Albert Einstein, Bill Gates, Stephen Hawking, Nero, Maria Madalena, Fidel Castro e Madre Tereza de Calcutá.

A partir dessa dinâmica, discutiu-se com os alunos os pré-conceitos e a incapacidade de se julgar o caráter de alguém pelo fato de esta ter ou não estudo, ser homem ou mulher, ter muito dinheiro ou ser pobre, entre outras características.

No quarto encontro, foi realizada uma dinâmica de grupo para discutir o preconceito de gênero. No quadro, escreveram-se as palavras HOMEM e MULHER, uma de cada lado, separados por uma linha vertical. Os alunos deveriam dizer palavras que caracterizassem os homens e, em seguida, as mulheres.

As palavras utilizadas para caracterizar os homens foram: Alto, Falso, Ignorante, Barba, Músculos, Gordinho, Pé grande, Bundudo, Intelectual, Bruto, Fofoqueiro e Sínico. Já as palavras associadas às mulheres foram: Linda, Inteligente, Carinhosa, Assanhada, Oferecida, Fofoqueira, Estressada, Vaidosa, Louca, Chorona, Ambiciosa, Oportunista, Bipolar e Inconstante.

A partir disso, perguntou-se aos alunos se alguns homens também não possuíam as características descritas para as mulheres e vice-versa. Analisou-se cada uma das palavras e isso fez com que os próprios alunos chegassem à conclusão de que todas as características descritas podem estar presentes tanto em homens como em mulheres. Além disso, para complementar essas discussões, utilizou-se vídeos de comerciais que retratavam a mulher e o homem em situações sexistas.

Finalizada a discussão sobre preconceito de gênero, partimos para a discussão de preconceito cultural. Para isso, utilizou-se um resumo do texto intitulado O Ritual do Corpo Entre os Sonacirema, da autoria de Horace Minner. Realizou-se, junto aos alunos, a leitura do texto. Alguns alunos pareceram bastante chocados com os rituais apresentados, outros, pareceram perceber rapidamente que se tratava de nós mesmos, o povo americano. Discutiuse com os alunos, a partir do texto lido, os conceitos de Etnocentrismo e Relativismo Cultural.

No quinto encontro, discutimos o preconceito racial. Utilizamos, para isso, recursos audiovisuais, como fotos e vídeos. Em seguida, foi pedido aos alunos que procurassem em revistas imagens de pessoas brancas e negras, para saber como elas eram retratadas. Foram confeccionados cartazes com recortes de revistas feitos pelos próprios alunos. 
Além disso, debatemos a influência da mídia na disseminação do preconceito, já que a mídia impõe padrões de beleza que, muitas vezes, são difíceis, ou até mesmo impossíveis, de serem alcançados. Para enriquecer essa discussão, apresentamos imagens que retratam os padrões de beleza ao redor do mundo e no decorrer dos anos.

No sexto encontro, decidimos trabalhar o preconceito direcionado à orientação sexual. Para falar sobre esse assunto, resolvemos nos aprofundar ainda mais, mostrando aos alunos a independência entre Sexo Biológico, Identidade de Gênero e Orientação Sexual. Para essa aula, foi necessário encaminhar bilhetes aos pais dos alunos menores de 18 anos. Essa atitude foi necessária, e sugerida pelo coordenador da escola, para evitar possíveis problemas com os pais dos alunos.

Sabendo das contradições e preconceitos relacionados ao assunto, tomaram-se todos os cuidados possíveis no planejamento da aula. Utilizaram-se recursos áudios-visuais e materiais bastante didáticos. Além disso, durante todo o tempo, ficou claro que a aula aconteceria, primeiramente, como uma discussão, onde todos os alunos poderiam se expressar, sem medo de retaliações.

A experiência da aula foi incrivelmente positiva. Os alunos se mantiveram atentos às explicações, questionaram, esclareceram dúvidas e discutiram. Em alguns momentos, foi possível notar que os alunos estavam confusos com alguns conceitos, principalmente no que se trata da independência entre identidade de gênero e orientação sexual. Foi dito aos alunos que uma pessoa pode nascer homem, identificar-se com o gênero feminino e sentir-se sexualmente atraído por mulheres. Os alunos se mostraram confusos e buscou-se, pacientemente, ouvir e esclarecer suas dúvidas.

Alguns alunos relataram ser difícil compreender esses conceitos e justificaram-se a partir de argumentos teístas. Deve ficar claro que, em momento algum, tentamos mudar as concepções dos alunos, forçando-os a aceitar ideias com as quais eles não estão familiarizados. Desde o inicio, esclareceu-se que a aula tinha o objetivo de discutir e debater o assunto de forma horizontal e igualitária.

Para finalizar, realizou-se um último encontro, que objetivou concluir as atividades, retomando todos os temas trabalhados. Os alunos relataram que costumavam compreender os assuntos trabalhados de forma diferente e que os encontros foram importantes para que eles assumissem posturas mais respeitosas em relação às outras pessoas. Além disso, houve relatos que evidenciaram a importância do projeto para a constituição da autoimagem e fortalecimento da autoestima. Considerando os relatos dos alunos, é de indiscutível importância que a escola inclua em sua proposta curricular, como bem destaca Araújo (2000), atividades que contribuam para o reconhecimento das dimensões constituintes da natureza humana, atuando sobre elas sem perder a dimensão de totalidade da personalidade.

\section{CONSIDERAÇÕES FINAIS}

Baseado nos objetivos desse trabalho, podemos concluir que os alunos pouco sabiam ou pouco se interessavam sobre os temas discutidos, desconhecendo a importância social das temáticas, mas que, em sua maioria, se mostraram dispostos a aprender. As dinâmicas de grupo provaram ser um ótimo instrumento de aprendizado, pois além de prenderem a atenção dos alunos, as dinâmicas os aproximaram dos conceitos trabalhados, uma vez que possibilitaram uma vivência prática.

Além disso, de acordo com a Lei de Diretrizes e Bases da Educação Nacional (1996), o currículo do ensino médio deveria adotar metodologias de ensino e avaliação que estimulassem a iniciativa dos próprios estudantes. Isso reforça a hipótese de que as dinâmicas de grupo se constituem como instrumentos potencialmente úteis na promoção de aprendizagens significativas e, portanto, deveriam ser utilizados abundantemente no processo de ensino-aprendizagem.

A avaliação do projeto foi feita de forma contínua, durante toda a realização do mesmo, como pedem os Parâmetros Curriculares Nacionais (1997). O objetivo não era avaliar os alunos de forma sistemática e tradicional, mas sim, avaliar o nosso próprio comprometimento com o desenvolvimento e a aprendizagem dos alunos, buscando nos superar a cada encontro.

Os encontros mostraram ainda que a reinserção da disciplina de Psicologia no Ensino Médio se faz necessária já que as demais disciplinas do currículo escolar pouco conseguem abordar temas de fundamental importância para a formação da autonomia e da cidadania. Além dos temas discutidos no trabalho realizado, outros temas se mostraram importantes, como a sexualidade, do ponto de vista psicossocial, a motivação e a autoestima. Temas que poderiam ser trabalhados em uma disciplina de Psicologia. 
Esse trabalho tem como um de seus principais objetivos, contribuir para as discussões a respeito da relação entre cidadania e educação. Discussão essa que, apesar de constantemente presente, precisa ser trabalhada mais profundamente, com muita dedicação por parte de educadores, pesquisadores e estudantes. Afinal, como afirma Araújo (2000), só é possível pensar a relação entre democracia, cidadania e educação se entendermos que essa é uma relação, inexoravelmente, complexa.

\section{REFERÊNCIAS}

[1] ARAÚJO, Ulisses Ferreira de. Escola, democracia e a construção de personalidades morais.

[2] Educação e Pesquisa, São Paulo, v.26, n.2, 91-107, 2000. Disponível em: <http://www.scielo.br/scielo.php?script=sci_arttext\&pid=S151797022000000200007\&lang=pt >. Acesso em: 12 jul. 2015.

[3] ARAÚJO, Ulisses Ferreira de. Pedagogia de projetos e direitos humanos: caminhos para uma educação em valores. Pro-Posições, Campinas, v.19, n.2, 193-204, 2008. Disponível em: <http://www.scielo.br/scielo.php?script=sci_arttext\&pid=S010373072008000200014\&lang=pt>. Acesso em: 12 jul. 2015.

[4] BRASIL. Lei no 9.394, de 20 dez. 1996. Estabelece as Diretrizes e Bases da Educação

[5] Nacional. Diário Oficial [da] República Federativa do Brasil, Brasília, DF, 23 dez. 1996. Disponível em: <http://portal.mec.gov.br/seed/arquivos/pdf/tvescola/leis/lein9394.pdf>. Acesso em: 12 jul. 2015.

[6] BRASIL. Ministério da Educação (MEC). Portaria no 260, de 30 de dezembro de 2010. Normas gerais do Programa Institucional de Bolsa de Iniciação à Docência - PIBID.

[7] Disponível em:

[8] <https://www.capes.gov.br/images/stories/download/legislacao/Portaria260_PIBID2011_No masGerais.pdf>. Acesso em: 13 jul. 2015.

[9] BRASIL. Ministério da Educação (MEC). Secretaria de Educação Fundamental (SEF).

[10] Diretrizes Curriculares Nacionais da Educação Básica. Brasília: MEC/SEF, 2013. Disponível em: <http://educacaointegral.org.br/wpcontent/uploads/2014/07/diretrizes_curiculares_nacionais_2013.pdf>. Acesso em: 13 jul. 2015.

[11] BRASIL. Ministério da Educação (MEC). Secretaria de Educação Fundamental (SEF). Parâmetros Curriculares Nacionais - Ensino Médio. Brasília: MEC/SEF, 2000. Disponível em: <http://portal.mec.gov.br/seb/arquivos/pdf/blegais.pdf>. Acesso em: 12 jul. 2015.

[12] BRASIL. Ministério da Educação (MEC). Secretaria de Educação Fundamental (SEF).

[13] Parâmetros Curriculares Nacionais - Introdução aos Parâmetros Curriculares Nacionais. Brasília: MEC/SEF, 1997. Disponível em:

[14] <http://cptstatic.s3.amazonaws.com/pdf/cpt/pcn/volume-01-introducao-aos-pcns.pdf>. Acesso em: 12 jul. 2015.

[15] KOHATSU, Lineu Norio. A reinserção da disciplina de psicologia no ensino médio: as especificidades da psicologia e os desafios do atual contexto educacional. Psicologia Ensino \& Formação, Brasília, v.1, n.1, 53-66, 2010. Disponível em:

[16] <http://pepsic.bvsalud.org/scielo.php?pid=S2177-20612010000100006\&script=sci_arttext>. Acesso em: 14 jul. 2015.

[17] MULLER, Adriana; ALENCAR, Heloisa Moulin de. Educação moral: o aprender e o ensinar sobre justiça na escola. Educação e Pesquisa, São Paulo, v.38, n.2, 453-468, 2012 . Disponível em: <http://www.scielo.br/scielo.php?script=sci_arttext\&pid=S151797022012000200012\&lang=pt>. Acesso em: 14 jul. 2015.

[18] OLIVEIRA, Glycia Melo de; CAMINHA, Iraquitan de Oliveira; FREITAS, Clara Maria Silvestre Monteiro de. Relações de convivência e princípios de justiça: a educação moral na escola. Psicologia Escolar e Educacional, Campinas, v.14, n.2, 261-270, $2010 . \quad$ Disponível <http://www.scielo.br/scielo.php?script=sci_arttext\&pid=S141385572010000200008\&lang=pt>. Acesso em: Acesso em: 14 jul. 2015. 


\section{Capítulo 4}

\section{O PIBID² pedagogia em uma escola do campo: O foco na leitura e escrita dos anos iniciais do ensino fundamental}

\section{Amanda Nascimento Silva de Oliveira \\ Maria Joselma do Nascimento Franco}

Resumo : Tomando como objeto o repertório de leitura e escrita das crianças do campo e a experimentação dos processos de ensino, revelados na condição de aprendizagem. 0 estudo é fruto da experiência no Programa Institucional de Bolsa de Iniciação à Docência ( PIBID), Pedagogia - CAA-UFPE em 2015. Objetivando apresentar à experiência dos iniciantes a docência, com crianças de baixo repertório de leitura e escrita e a experimentação dos processos de ensino, revelados em aprendizagem, ressignificada. Referenciadas em Silva (2010) para tratar da formação de professores/as; Teberosky e Colomer (2003), Ferreiro (1999) e Koch e Elias (2012), para discutir leitura, escrita e suas significações; além de Ribeiro (2012), Molina e Sá (2012) para tratar da educação rural, do campo e da escola. Metodologicamente trabalhamos a abordagem colaborativa. A intervenção se desenvolveu com estratégias diversificadas, focadas no lúdico e

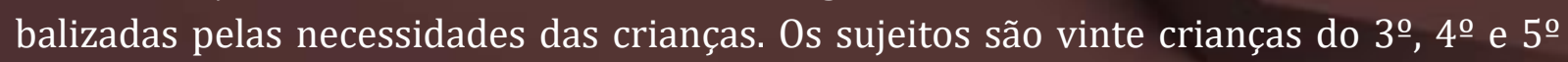
anos do ensino fundamental e dez professores/as iniciantes. As sessões semanais com as crianças e professores/as foram de três horas cada e envolveram regras de convivência, a vivência de dinâmicas para tratar as relações, atividades de intervenção com foco nas potencialidades dos sujeitos. Os resultados mostram avanços no repertório de leitura e escrita. As crianças e os/as professores/as, ao passarem pela experimentação de processos de ensino, que ressignificados, se revelaram em aprendizagens, se tornaram protagonistas. E os/as professores/as iniciantes se reconheceram como profissionais que, diante do desafio posto, conseguiram coletivamente experimentar possibilidades de intervenção com resultados bem sucedidos.

Palavras-chave: PIBID, Leitura, Escrita, Formação.

2 Programa Institucional de Bolsa a Iniciação à Docência, financiado pela CAPES. 


\section{INTRODUÇÃO}

Aproximar os saberes apreendidos na formação inicial ao contexto real é um exercício fundamental na construção da profissionalização docente. Até então, o estágio é parte fundamental para estreitar essa relação teoria/ prática e escola/ limitações nesta relação formação universitária inicial e estágio, considerando o curto tempo que temos para a apropriação da complexidade da sala de aula e suas nuances, além da identificação dos desafios que emergem no contexto e a necessidade de problematizá-los para que numa perspectiva coletiva possamos construir proposições que contribua com a intervenção para minimização dos desafios contextuais.

Com a constituição do PIBID (Programa Institucional de Bolsa a Iniciação à Docência), identifica-se que este movimento entre formação inicial de professores e sua articulação com a escola, como lócus formativo, que articula teoria e prática ganha novos contornos na formação.

A troca de saberes, a identificação dos desafios, a constituição de proposições e a experimentação, pautada na leitura e escrita, articulada a reflexão e aos processos de ensino, que se revelaram em aprendizagens significativas, foram algumas das experiências evidenciadas no desenvolvimento do PIBID, em uma escola do campo, que propiciou aos sujeitos educativos, aprendizagens, tanto para as crianças participantes, quanto para os professores em formação inicial.

Nessa perspectiva, sabendo das dificuldades enfrentadas nos processos de alfabetização e letramentos nos anos iniciais do ensino fundamental, possibilitou aos iniciantes à docência em 2015, atuar na escola do campo, com crianças que apresentaram baixo repertório em leitura e escrita, de maneira a contribuir com a formação das mesmas, assim como a dos/as professores/as em formação inicial com atuação em sala de aula.

\section{REFLEXÕES EM TORNO DO PROGRAMA PIBID-PEDAGOGIA ENQUANTO FORMAÇÃO INICIAL}

O PIBID (Programa Institucional de Bolsa de Iniciação à Docência), subprojeto Pedagogia, do Centro Acadêmico do Agreste - CAA-UFPE tem experimentado metodologias de intervenção, possibilitando aos professores iniciantes (pibidianos) identificar desafios, problematizá-los e, pelo exercício da reflexividade coletiva e do planejamento de ações conjunta, constituir intervenções que ajudem a superar os desafios postos.

Na perspectiva acima posta, os/as pibidianos/as trabalharam com crianças em uma escola do campo, que para a instituição, apresentavam baixo repertório de leitura e escrita, de modo a focar na evolução destes processos, por meio de diferentes estratégias de ensino, ressignificando-os a partir de atividades pautadas na alfabetização e letramento, rumo a formação do sujeito leitor.

Nessa direção, o presente Programa possibilitou aos/as pibidianos/as em formação inicial, articulação entre os saberes da realidade social, os escolares e os científicos. Diante do exposto, compreende-se que a inserção dos professores em formação, possibilita a construção de saberes, reflexões de práticas e a tomada de consciência, do real comprometimento com sua formação profissional e a formação de outros. Nesta perspectiva,

0 desafio do trabalho docente é não favorecer as aprendizagens individuais, mas sobretudo, coletivas. Desenvolver formas de ensinar e de aprender que integrem os sujeitos, constituindo uma rede de aprendizagens e ensinagens, torna-se um imperativo pedagógico. (SILVA, 2010, p.39)

Assim, aprender a lidar com os desafios que emergem no cotidiano e a tratá-los a partir da coletividade na escola, gera aprendizagens integrativas, uma condição fundamental na aprendizagem do ofício professoral, inclusive no que diz respeito à função que tem a escola na vida das crianças, que é possibilitar processos de aprendizagem, sobretudo no que se refere à ampliação do conhecimento sistematizado.

Logo, foi na perspectiva de trabalhar os processos de alfabetização e letramento, com as crianças da escola do campo, que apresentavam baixo repertório de leitura e escrita, que o PIBID 2015, a partir dos/as professores/as (pibidianos/as) em formação, se consolidou, trabalhando sistematicamente com as crianças do $3^{\circ}$, $4^{\circ}$ e $5^{\circ}$ anos de uma escola do campo em Caruaru, o que gerou ampliação de conhecimentos para os sujeitos envolvidos, professores em formação e crianças

Nossa opção por trabalhar com as crianças do campo deve-se ao fato de compreendermos que, estas são sujeitos de direito, que nem sempre têm suas necessidades atendidas, sobretudo quando se trata de 
qualificar o repertório de conhecimento, tendo em vista a concepção predominantemente alimentada para esta população que é de "oferecer conhecimentos elementares de leitura, escrita e operações matemáticas simples, mesmo a escola rural multisseriada não tem cumprido esta função, o que explicita as altas taxas de analfabetismo e os baixos índices de escolarização nas áreas rurais" (RIBIEIRO, p.293, 2012).

É por contrariarmos esta concepção e optarmos pela defesa da educação do campo, que nos desafiamos, pautando as ações de intervenção, no fundamento de que nas escolas do campo “(...) trabalho pedagógico deve ser a materialidade da vida real dos educandos, a partir da qual se abre a possibilidade de ressignificar o conhecimento científico, que já é, em si mesmo, produto de um trabalho realizado por centenas de homens e mulheres(...) (MOLINA, SÁ, p. 329, 2012). 0 que nos desafia a constituir com as crianças e os/as pibidianos/as estas ressignificações, no movimento de articulação da vida no campo com o conhecimento sistematizado.

\subsection{A LEITURA E ESCRITA NOS ANOS INICIAIS DO ENSINO FUNDAMENTAL NA ESCOLA DO CAMPO.}

As discussões em torno do que de fato significa formar leitores nas escolas, e se a mesma, tem conseguido viabilizar experiências significativas no contexto escolar, tem desafiado os/as professores/as e formadores/as de professores/as. Como sabemos,

(...) a leitura é uma atividade necessária não só ao projeto educacional do indivíduo, mas também ao projeto existencial, e que, além de ser um ato que se realiza no âmbito da cognição, apresenta caráter social, histórico e político.(MAIA,2007, p.29)

É comum encontrarmos nos anos iniciais do ensino fundamental, crianças que apresentam um repertório de leitura e escrita, aquém do esperado. Esta condição, provoca nos mesmos um quadro de desestabilidade emocional que degrada sua condição humana, em relação aos que dominam o referido repertório, o que nos desafia, não apenas pelo compromisso educacional que temos, mas sobretudo pela condição humana, política e social das crianças, assim como dos/as professores/as em formação.

Para tanto, compartilhamos da compreensão de que "A leitura é, pois, uma atividade interativa altamente complexa de produção de sentidos [...] na qual se leva em conta as experiências e os conhecimentos do leitor (KOCH, ELIAS, 2012, p. 11 grifo dos autores), o que exige do/a professor/a ao trabalhá-la com as crianças, situar, contextualizar os instrumentos utilizados, assim como mobilizá-las na condição de sujeitos/leitores ativos que dialoguem com o autor criticando-o, contradizendo-o, desfrutando ou rechaçando, de forma a dar sentido e significado ao que lê. (SOLÉ, 2003).

Concebemos ainda que "Ler é uma atividade extremamente complexa e envolve problemas não só semânticos, culturais, ideológicos, filosóficos, mas até fonéticos" ( CAGLIARI,2009, p.130).

Nesta direção, entram as estratégias de exploração das capacidades cognitivas, além das intervenções necessárias, o que exige o aprofundamento desses saberes por parte do/a pibidiano/a, pautados em um ensino que se revele em aprendizagem, com sentidos, o que exige uma concepção de leitura pautada numa perspectiva “(...) interacional (dialógica) da língua, os sujeitos são vistos como atores/construtores sociais, sujeitos ativos que - dialogiacamente - se constroem e são construídos no texto (...) (KOCH, ELIAS, 2012, p. 10 grifo dos autores). Esta perspectiva, constitui um outro movimento no trato da leitura articulada a escrita de forma a ressignificá-las

Do ponto de vista pedagógico, as primeiras formas de apreciação de símbolos e de significados, parte inicialmente das hipóteses apresentadas nos desenhos, rabiscos das crianças.

Porém, para compreendê-los, FERREIRO (1999) apud TEBEROSKY e COLOMER (2003), classifica esses primeiros escritos em:

- Pré - silábico: seria aquela criança que não diferencia a relação entre a escrita e os sons da fala;

- Silábico Inicial: a criança começa a perceber que a palavra pode corresponder a quantidades de partes que se reconhece na emissão oral ;

- Hipótese silábica: a criança representa uma sílaba por letra, sem emitir sílabas e sem repetir letras; 
- Silábico Alfabético: a criança começa a perceber que a sílaba não pode ser considerada como uma unidade, ou seja, não basta uma letra por sílaba;

- Período Alfabético: a criança escreve com base na relação existente entre fonemas e letras (p. 24-25)

O domínio da classificação acima exposta pelo/a pibidiano/a, é fundamental no trabalho com os processos de leitura e escrita, considerando que é a partir dela que os/as mesmos/as lêem suas produções e constroem atividades de intervenção didática, para alavancar a ampliação do repertório de leitura e escrita das crianças.

A escrita na perspectiva acima tratada, mediada pela intervenção competente do/a pibidiano/a, marcada por uma condução ativa das crianças, enquanto sujeitos, protagonistas e autores de suas próprias produções.

\section{METODOLOGIA}

A metodologia adotada se pautou na abordagem colaborativa. A população participante é de 20 crianças, sendo 12 do $3^{\circ}$ ano, 4 do $4^{\circ}$ ano e 4 do 5o ano do ensino fundamental, além dos 10 pibidianos/as, cada um atendendo 2 crianças em cada sessão, com 2 sessões por semana de 3 horas cada, no período do contraturno de março a novembro de 2015.

Inicialmente foi realizada uma avaliação diagnóstica. Nela, as crianças escreveram seu nome inicial, identificaram o número de letras correspondentes ao seu nome; reconheceram letra inicial do mesmo; pintaram as vogais do seu nome e escreveram o alfabeto, conforme exigência do descritor $1^{3}$ para a alfabetização, que é de reconhecer letras.

Na segunda parte da avaliação, as crianças fizeram a leitura de imagens e escreveram o nome delas e foi analisado se os mesmos conseguiam atingir o descritor 2: reconhecer sílabas. Em seguida, foi realizado um ditado de palavras, em que foi observado o cumprimento do descritor 3: estabelecer relação entre unidades sonoras e suas representações gráficas. O objetivo desta avaliação foi identificar em que condições se encontravam as habilidades previstas para o ano de escolarização de cada criança, e a partir delas, constituir o plano de intervenção, rumo à ampliação das aprendizagens.

A partir da análise dos instrumentos, levantamos o perfil de aprendizagem das crianças e passamos a planejar o plano de intervenção. 0 perfil foi elaborado se pautando na Psicogênese da língua escrita, Ferreiro (1986). A apropriação do Sistema de Escrita Alfabética ( SEA ), é classificada por MORAIS ( 2012), em: pré- silábica, silábica, silábica- alfabética e alfabética, e foi tomada como referência para o desenvolvimento dos trabalhos.

Munidas do perfil de aprendizagem das crianças, passamos a planejar as sessões que foram desenvolvidas pelos/as pibidianos/as com as crianças, atendendo suas necessidades para que atingissem não apenas o repertório de conhecimento esperado nos anos de escolarização em que se encontravam, mas também ressignificassem o sentido de aprender, do estar juntos/as, além da qualidade das relações estabelecidas entre elas e os/as pibidianos/as.

Para planejar as sessões, tomamos por base, o desenvolvimento de uma dinâmica no início de cada sessão, para trabalhar as relações entre as crianças, e elas com os/as pibidianos/as. Em seguida, o trato de um gênero textual, e a partir deles, os descritores/expectativas de aprendizagem. Estes são aqui tratados como: D1: reconhecer letras, D4: Ler palavras, D5: Ler frases, D6: Localizar informação explícita em textos, D7: Reconhecer assunto de um texto, D8: Identificar a finalidade do texto, D10: Inferir informação.

Ainda no que se refere ao desenvolvimento das atividades propostas no subprojeto Pedagogia semanalmente foi escolhido um gênero textual e desde então, explorados os aspectos fonológicos, sonoros, e de representação gráfica. Cada pibidiano/a elaborou as atividades conforme as necessidades das crianças que atendiam. Para enriquecer as aprendizagens, foram confeccionados materiais pedagógicos como jogo dos padrões silábicos, xilogravura, cordéis, poemas, jornal e também utilizados os existentes na própria escola. Os materiais construídos e trabalhados, no final de cada sessão, foram recolhidos para acompanhamento e avaliação dos possíveis avanços e/ou intervenções durante a vigência do subprojeto. 
Ao final de 2015 realizou-se uma nova avaliação diagnóstica. Em uma das questões apresentadas, além de contextualizar o que se tratava na questão, as crianças teriam de assinalar a alternativa que correspondia ao número de sílabas da palavra "CENOURA". Essa atividade continha o que se pretendia no descritor 2 reconhecer sílabas. Já em outra, havia um texto instrutivo, o qual se referia ao descritor 8 , que propunha identificar a finalidade do texto. Outros gêneros foram tratados e por fim, as crianças escreveram sobre sua participação no PIBID.

Essas informações coletadas, juntamente com as produções semanais e os depoimentos dos sujeitos registrados no diário de campo, possibilitou a constituição do corpus para a pesquisa.

\section{RESULTADOS}

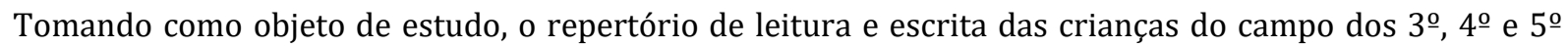
anos e a experimentação dos processos de ensino, revelados na condição de aprendizagem, a partir do baixo repertório de conhecimento das habilidades leitoras e escritoras das crianças. 0 presente estudo se propôs a apresentar a experiência desenvolvida com os iniciantes docentes no contexto da escola do campo, que se desafiaram numa perspectiva de experimentação da docência, a alavancar o desenvolvimento do repertório de leitura e escrita das crianças.

Inicialmente, as crianças que ingressaram no subprojeto Pedagogia Pibid - na escola do campo, com um repertório aquém do ano de escolaridade que cursavam, se desafiaram juntamente com os/as pibidianos/as no desenvolvimento de atividades que apontaram para o perfil de aprendizagem em que se encontravam.

A partir do perfil constituído, o desafio dos/as pibidianos/as foi planejar as sessões de trabalho, de forma a ressignificar as atividades desenvolvidas, em dupla e acompanhadas por um/a pibidiano/a. Cada sessão era precedida de atividades coletivas como o desenvolvimento de uma dinâmica inicial, objetivando trabalhar as relações. Investiu-se também na constituição das regras de convivência, assim como a cada semana, no trato de um gênero textual. Após as atividades coletivas, cada pibidiano/a trabalhou com uma dupla de crianças. Cada dupla é atendida a partir de suas necessidades, com base no perfil de aprendizagem elaborado.

0 desenvolvimento das sessões durante o ano de 2015, qualitativamente, apontou para um avanço notório no conjunto das 20 crianças. Em relação especificamente as do $3^{\circ}$ ano, que ainda se encontravam na fase inicial do ( SEA), chegaram ao final do ano escrevendo palavras, escrevendo seu nome, constituindo interpretações e produzindo textos.

Aos que estavam na fase silábica alfabética e Alfabética, estes apresentaram um salto qualitativo em suas produções e concluíram os trabalhos recitando pequenos poemas e elaborando bilhetes para os seus/as professores/as.

A condição de avanço no repertório de leitura, escrita e a ressignificação destes processos, é validado, quando na conclusão do Programa na comunidade, foi organizada uma exposição, com a presença da comunidade escolar e dos/as pais/mães das crianças, e elas foram as protagonistas da exposição, apresentando as produções, fazendo a leitura das atividades, mostrando para o público o que conseguiram produzir. Em suas exposições identificávamos o quanto estavam imbuídos do prazer de fazer aquela exposição, validando sua evolução frente aos processos de leitura e escrita ressignificados, tornando a exposição o ápice do subprojeto PIBID - Pedagogia, o que gerou nos participantes pibidianos/as a consciência do dever cumprido, além do desejo de permanência no Programa.

\section{REFERÊNCIAS}

[1] SILVA, J. F. Avaliação na perspectiva formativa: pressupostos teóricos e práticos. Porto Alegre: Mediação, 2010.

[2] RIBEIRO, M. Escola Rural. In: CALDAT, R. S. et al. Dicionário de Educação do Campo. Rio de Janeiro, SP: Escola Politécnica de Saúde Joaquim Venâncio, Expressão Popular, 2012

[3] MOLINA, M.; SÁ, L. M. Escola do Campo. In: R. C. CALDAT et al. Dicionário de Educação do Campo. Rio de Janeiro, SP: Escola Politécnica de Saúde Joaquim Venâncio, Expressão Popular, 2012.

[4] MAIA, Joseane. Literatura na formação de leitores e professores. São Paulo: Paulinas, 2007. 
[5] KOCH, I. V; ELIAS, V. M. Leitura, texto e sentido. In: KOCH, I. V; ELIAS, V. M. Ler e compreender: os sentidos do texto. 3 ed, São Paulo: Contexto, 2012.

[6] SOLÉ, I. Ler, leitura, compreensão: “sempre falamos da mesma coisa?” In: TEBEROSKY, A. et al. Compreensão de leitura: a língua como procedimento. Porto Alegre: Artmed, 2003.

[7] CAGLIARI, Luiz Carlos. Alfabetização e lingüística. São Paulo: Scipione, 2009.

[8] TEBEROSKY, A. COLOMER, T. Aprender a ler e a escrever: uma proposta construtivista. Porto Alegre: Artmed, 2003.

[9] FERREIRO, E. TEBEROSKY, A. Psicogênese da língua escrita. Porto Alegre: Artes médicas, 1986.

[10] MORAIS, Arthur Gomes.Sistema de escrita alfabética.São Paulo: Melhoramentos, 2012.

[11] WWW.inep.gov.br/web/provinhabrasil Acesso em 08/08/2016 às 15:50 h 


\section{Capítulo 5}

\section{Formação inicial de professores: Constituição dos saberes docentes nas ações do PIBID}

\section{Anna Raquel da Silva Marinho}

\section{Rogério Emílio da Silva}

Francisco das Chagas da Silva Junior

\section{Pauleany Simões de Morais}

Resumo: Versa o presente trabalho a discutir as contribuições do Programa Institucional de Bolsa de Iniciação à Docência (PIBID) para a constituição dos saberes docentes no Curso de Graduação da Licenciatura em Informática oferecido no Instituto Federal de Educação, Ciência e Tecnologia do Rio Grande do Norte (IFRN) - Campus Natal Zona Norte. Recebe destaque a repercussão das ações didático-pedagógicas que vêm sendo realizadas pelos bolsistas nas Escolas Públicas, no sentido de desenvolver a formação inicial teórico-prática necessária à docência. Como metodologia, utilizou-se revisão de literatura embasada nas reflexões sobre os saberes, a formação e a profissionalização docente, bem como depoimentos de 12 bolsistas oriundos de questionário aplicado. Observou-se a significativa contribuição das ações vivenciadas pelos bolsistas no PIBID para formação inicial dos futuros professores com oportunidade de constituir os saberes docentes necessários à prática educativa. Os depoimentos evidenciam como os bolsistas percebem a relevância do Programa para compreensão da prática docente que exercerão como profissionais no futuro. Apesar dos impasses encontrados com a ausência de um profissional Licenciado em Informática nas escolas públicas, vem-se mudando a realidade e a atuação nos laboratórios existentes nessas instituições.

Palavras-chave: Saberes docentes, Formação inicial, Licenciatura em Informática, PIBID. 


\section{INTRODUÇÃO}

Na atualidade, a formação do profissional à docência assume uma nova perspectiva junto a sociedade, pois a formação inicial vem assumindo um novo significado direcionada às ações no interior das realidades escolares, com ações dentro da própria escola pública. Segundo Freitas $(2010$, p. 44), "O processo de formação do profissional da educação, no âmbito do trabalho pedagógico escolar que ocorre sob determinadas circunstâncias, é um movimento contínuo e em constante transformação". Por isso, a formação inicial vem sendo foco em discussões acadêmicas e ações governamentais. Merece destaque o Programa Institucional de Bolsa de Iniciação à Docência (PIBID), que vem promovendo ações de formação inicial, contribuindo de maneira significativa para a constituição dos saberes pedagógicos necessários à prática da docência.

Neste trabalho procura-se evidenciar a relevância da formação inicial voltada à docência com destaque à atuação do PIBID no Instituto Federal de Educação, Ciência e Tecnologia do Rio Grande do Norte (IFRN), Campus Natal - Zona Norte. Dentro desse contexto, apresenta-se uma discussão sobre formação inicial de professores, as contribuições do PIBID à formação docente, bem como as repercussões das ações vivenciadas nas escolas públicas. Como fundamento metodológico realizou-se a aplicação de um questionário elaborado pelos Coordenadores de área junto aos bolsistas do Programa, desenvolvido e aplicado após um ano de observação de atuação. As questões contemplavam, particularmente, a contribuição do PIBID à formação docente e constituição dos saberes necessários a prática educativa.

A reflexão voltada à constituição dos saberes docentes permeia todo este trabalho no sentido de compreender suas representações para a formação dos bolsistas que buscam sua profissionalização em um Curso de Graduação. Tardif (2012, p. 54) define o significado do saber docente como "saber plural, formado de diversos saberes provenientes das instituições de formação, da formação profissional, dos currículos e da prática cotidiana". Com essa concepção, a oportunidade de relacionar os fundamentos acadêmico-científicos, recebidos nas disciplinas que cursam, e as práticas vividas nas escolas públicas. Neste trabalho, os depoimentos dos bolsistas esclarecem as contribuições do programa para a constituição dos saberes pedagógicos nessa formação inicial oferecida.

\section{FORMAÇÃO INICIAL DOCENTE: RELAÇÃO TEORIA E PRÁTICA}

Quando tratamos de formação docente, as discussões percorrem duas vertentes: a dos saberes (técnicocientíficos) e a das possíveis práticas que podem ser realizadas no âmbito escolar. De acordo com Tardif (2002, p. 228), os professores de profissão possuem saberes específicos que são mobilizados, utilizados e produzidos por eles no âmbito de suas tarefas cotidianas nas universidades e em diversos espaços escolares. É certo que os professores precisam possuir saberes específicos advindos de teorias. No entanto, para exercer a profissão de professor é necessário muito mais do que teoria. É necessária a vivência em sala de aula, o contato com os alunos. Dessa forma, pode ser constituída a prática da profissão, a partir do contexto escolar/social.

Defende-se que as universidades e as instituições de ensino são responsáveis pela formação inicial e/ou continuada dos professores, sendo assim têm como desafio abrir espaços nos currículos dos cursos para que exista uma relação de vivência teórica e prática dos discentes. Segundo Tardif (2002, p. 241), "vivemos de teorias, sendo que estas muitas vezes construídas por profissionais que nunca atuaram numa sala de aula".

Para Tardif (apud ALMEIDA E BIAJONE, 2007, p. 292), a formação inicial visa habituar os alunos, futuros professores, à prática profissional dos professores de profissão e fazer deles práticos e reflexivos. Neste sentido, é possível afirmar que a essência da profissão professor encontra-se na prática. Todavia, não se pode esquecer a importância que tem a teoria, caracterizando-a como o alicerce no desenvolvimento da prática. Esta relação é fundamental para a formação de bons profissionais do ensino, ou melhor, para contribuir na constituição dos saberes de futuros educadores.

Podemos considerar que existe uma relevância na constituição dos saberes docentes, pois por meio dos estágios curriculares, os licenciandos têm a oportunidade de envolver-se em atividades de concepção, planejamento e ações que culminam na vivência da prática docente. Para Almeida e Carvalho (2012, p. 3), torna-se significativo pensar que "o saber profissional do professor bem como sua experiência de atitudes, de reflexão, de pesquisa e de intervenção, deve ser considerado sob uma ótica de determinada totalidade e não reduzido a certas competências técnico-profissionais". 
Gadotti (apud Almeida e Carvalho, 2012, p. 3) descreve o professor como um mediador do conhecimento, um aprendiz permanente frente ao aluno que tem papel de sujeito de sua própria formação. Ênfase deve ser dada aos saberes e neste contexto identificam-se alguns fatores principais: o gosto de aprender; o prazer em ensinar e o amor ao discente.

Podemos ressaltar que a profissionalização do professor está estritamente ligada a sua formação docente inicial. Contudo, para Ghedin, Almeida e Leite (2008), precisamos ressaltar que existe uma relevância na formação docente, entretanto podemos dizer que ela é uma necessidade social da escola, pois permite a constituição da identidade profissional, bem como a percepção das demandas atuais do contexto escolar e do trabalho docente.

Podemos considerar que todo processo de formação docente procura mediar as relações interpessoais e pessoais no decorrer da vida. A docência tem como papel principal apresentar a realidade de cada escola aos futuros professores, onde o discente tem na vida educacional toda sua concepção de que o ensino se dá por meio das práxis educativas exercidas em sala de aula, como uma ação unida entre professor-alunoescola.

\section{O PIBID COMO PROMOTOR DA FORMAÇÃO INICIAL DOCENTE}

A formação docente na Licenciatura apenas nos mostra as possibilidades de um novo mundo quando nos voltamos para a prática em sala de aula. No entanto, precisamos considerar que o professor precisa estar em constante aprendizado. 0 professor como profissional em educação precisa ascender para a realidade da escola e das turmas que ele vem a ministrar as disciplinas do currículo escolar. Considerando-se que o conhecimento base para a docência compete às seguintes categorias da base de conhecimentos do professor:

1) conhecimento do conteúdo; 2) conhecimento pedagógico (conhecimento didático geral), tendo em conta, especialmente, aqueles princípios e estratégias gerais de condução e organização da aula, que transcendem o âmbito da disciplina; 3) conhecimento do curriculum, considerado como um especial domínio dos materiais e os programas que servem como "ferramentas para o ofício" do docente; 4) conhecimento dos alunos e da aprendizagem; 5) conhecimento dos contextos educativos, que abarca desde o funcionamento do grupo ou da aula, a gestão e financiamento dos distritos escolares, até o caráter das comunidades e culturas; 6) conhecimento didático do conteúdo, destinado a essa especial amalgama entre matéria e pedagogia, que constitui uma esfera exclusiva dos professores, sua própria forma particular de compreensão profissional; 7) conhecimento dos objetivos, as finalidades e os valores educativos, e de seus fundamentos filosóficos e históricos (SHULMAN, 2005, p. 11).

O PIBID é um programa que concede bolsas a alunos de licenciatura, incentivando o aperfeiçoamento da formação docente com o propósito de portar melhorias para a educação pública brasileira. A portaria no 096, de 18 de julho de 2013, anexo I, art. 2o versa sobre os objetivos do PIBID. Dentre eles, está a valorização do magistério, a inserção dos licenciandos na rede pública de ensino, promover a integração entre educação superior e básica, promover experiências metodológicas que contribuam para a superação de problemas identificados no processo de ensino aprendizagem, contribuir para a articulação entre teoria e prática necessárias à formação dos docentes, elevando a qualidade das ações acadêmicas nos cursos de licenciatura. Portanto, é uma iniciativa para o aperfeiçoamento e valorização da formação inicial de professores.

Perceber os aspectos presentes no espaço escolar é de suma importância para que o licenciando possa consolidar sua formação acadêmica. No entanto, a docência busca consolidar o conhecimento de modo prático em sala de aula. O PIBID tem por objetivo concretizar este exercício de docência por meio do aprendizado em sala de aula, pois precisamos considerar que a realidade social e as expectativas dentro da comunidade escolar estão muito distantes uma da outra. Entretanto a realidade escolar precisa assumir um processo de colaboração mútua por ambas as partes para que se possa ser proposta uma reformulação dos saberes. 
Em relação às atividades iniciais do PIBID no Campus Natal - Zona Norte, os bolsistas responderam um questionário sobre as ações de docência já realizadas em seu primeiro ano de atuação nas escolas, e também sobre como eram as expectativas antes de iniciar as atividades.

\section{A VISÃO DOS LICENCIANDOS SOBRE A IMPORTÂNCIA DO PIBID}

Com relação às expectativas, muitos deles estavam preocupados com o que iriam encontrar, mas ficaram mais tranquilos por encontrarem escolas dispostas a ajudá-los, embora a precariedade da infraestrutura dos laboratórios e a dificuldade em estimular os alunos fossem consideráveis. De acordo com o que foi respondido pelos bolsistas que atuam na Escola A, é possível perceber que eles não estão encontrando grandes dificuldades, considerando a estrutura para atuar, assim como o interesse dos alunos e dos servidores da escola, como comprova o depoimento a seguir:

A escola demonstra interesse em buscar e trazer melhorias para os alunos através de oficinas e os alunos participam e se interessam pelos projetos. A realidade da escola supera um pouco as minhas expectativas, pois o laboratório é bem estruturado, nós temos o auxílio da supervisora que sempre conversa conosco sobre os alunos e sobre as ações que estão sendo desenvolvidas (Aluno A).

Na Escola B, as respostas foram bastante diferentes entre si, mas estavam principalmente relacionadas à infraestrutura do laboratório e à falta de interesse dos alunos em aprender e utilizar ferramentas computacionais de apoio a outras disciplinas. Por exemplo, o Aluno D disse que "a realidade inicial é chocante, no entanto o desenvolvimento foi dado gradativamente". Já o aluno B disse que sua expectativa era "diferente da encontrada na escola, por que a carência cultural é maior que no IFRN". 0 depoimento a seguir está de acordo com as respostas da maioria:

Sim, as minhas expectativas foram frustradas, pois é muito difícil manter e atrair o interesse dos alunos para as aulas. Isso se justifica porque os alunos não conseguem enxergar um motivo para perderem tempo nas aulas de Informática, já que não é uma disciplina obrigatória e as condições precárias do laboratório não ajudam. Melhor dizendo, isso tudo não justifica, mas explica. (Aluno E)

Com os bolsistas que atuam na Escola C, as respostas foram semelhantes aos da Escola B. O Aluno K disse que "ao conhecer alguns alunos, foi um choque percebê-los com pouca habilidade de leitura e escrita". Já o aluno H comentou o seguinte: "Eu não tinha noção da realidade da escola pública, mas a situação é pior do que eu pensava". A questão não só da insegurança em lecionar pela primeira vez, mas também a realidade em volta de onde está localizada a escola preocuparam o Aluno I:

As minhas expectativas eram preocupantes, pois não tinha experiência em lecionar, mas quando cheguei na escola vi que a realidade era outra. A situação da escola era muito precária, pois na sua localidade acontece muita violência ao seu redor (Aluno I).

O PIBID permite interiorizar e dar significado ao processo de ensino-aprendizagem na constituição saberes-fazeres docentes. Rosmann, Benvenutti e Facenda (2014, p. 79) falam sobre o caráter do trabalho docente e que se espera que seja possível desenvolver nos alunos "conhecimentos e habilidades, atitudes e valores que lhes possibilitem permanentemente irem construindo seus saberes-fazeres docentes a partir das necessidades e desafios que o ensino como prática social lhes coloca no cotidiano". No entanto, a identidade docente se faz por meio de um processo de construção e reconstrução de sua autonomia enquanto professor.

Todos os alunos exaltaram a importância do PIBID para sua formação como docentes, já que situações de aprendizagens reais possibilitam refletir sobre o processo de ensino- aprendizagem, de maneira a pensar sobre a prática educativa. Nesse contexto, o Aluno D disse que: "o PIBID possibilita 'ensaiar' a prática docente e literalmente perder o medo da sala de aula na figura do docente". Enquanto que o Aluno C disse que o PIBID é importante por permitir "conhecer de perto o cotidiano da escola e a realidade da informática na escola", o que se assemelha a outro relato apresentado pelo bolsista:

0 programa me colocou em contato com a rotina da escola. Sinto que participo mais dos encontros e reuniões pedagógicas e tenho oportunidade de praticar a docência. Embora a Informática precise 
batalhar pela visibilidade dessa disciplina, a escola onde trabalho tem sido receptiva (Aluno C).

O Aluno A fala da busca pelas melhores estratégias de ensino, já visualizando seu futuro como professor:

Ampliar a minha visão sobre como ocorre o processo de ensinar e a preocupação de buscar as melhores estratégias para atender as minhas necessidades como licenciando para que eu possa ter uma melhor atuação como professor (Aluno A).

Os Alunos E e L falam na importante contribuição deles como futuros professores para melhorar de alguma forma a educação na escola pública:

Conhecer a realidade na visão docente da escola pública foi muito importante, pois isso nos faz refletir se é isso mesmo que queremos para a nossa carreira, enfrentar essas dificuldades sabendo que não seremos recompensados devidamente por isso. Por outro lado, nos fez sentir o quanto é importante a nossa participação nesse cenário para melhorar esse ambiente, e contribuir efetivamente para melhorar a educação nessas escolas enquanto professores (Aluno E).

A formação como licenciando me faz ver e vivenciar as dificuldades e necessidades que a escola passa em seu dia-a-dia. A minha visão e perspectivas sobre o ensino e a realidade de cada um me faz ser mais motivado a melhorar e dar o melhor (Aluno L).

Nessa perspectiva, observa-se que o PIBID viabiliza a formação inicial ao contribuir para a constituição dos saberes docentes, permite articular aspectos teóricos e práticas necessários a profissionalização docente. Tardif (2012, p. 87) aponta a relevância dos bolsistas vivenciarem práticas de relações de trabalho:

Em várias ocupações - e esse é o caso do magistério - a aprendizagem do trabalho passa por uma escolarização mais ou menos longa, cuja função é fornecer aos futuros trabalhadores conhecimentos teóricos e técnicos que os preparem para o trabalho. Mas, mesmo assim, acontece raramente que a formação teórica não tenha de ser completada com uma formação prática, isto é, com uma experiência direta do trabalho, experiência essa de duração variável e graças à qual o trabalhador se familiariza com seu ambiente e assimila progressivamente os saberes necessários à realização de suas tarefas.

Ao analisar a fala dos bolsistas, observa-se a relevância do PIBID na formação inicial docente com vivências e dificuldades concretas que os estimulam a definir estratégias teórico- metodológicas necessárias às reflexões contínuas da prática educativa. Ainda torna-se perceptível a contribuição do programa para a compreensão das possíveis situações de aprendizagem, ao permitir a familiarização com o espaço escolar, sabendo que o trabalho na concretude real das atividades desenvolvidas na escola passa a ser entendido como articulador dos saberes necessários à docência. Sendo assim, a formação teórica vivenciada na graduação terá uma formação prática com a vivência das ações do PIBID numa realidade concreta que estimule os bolsistas a reflexões contínuas da prática docente.

A terceira questão era sobre a importância do PIBID para as escolas que recebem o programa. Vários dos alunos responderam a essa questão destacando que os bolsistas do PIBID levam ideias novas para as escolas não apenas para o laboratório de Informática, mas também com estratégias de aplicação da Informática no ensino, diferentemente do que acontece com alguns professores que insistem em estratégias mais tradicionais, o que muitas vezes deixa os alunos desinteressados. Foi destacado também nas respostas que os bolsistas estão contribuindo com aulas no laboratório de Informática, inclusive quando há ausência de professores, como respondeu o Aluno K, que disse que "ainda que não seja atribuição deles, o PIBID pode suprir a falta de professores" e conforme mostram os dois depoimentos a seguir:

O PIBID é uma luz na escuridão. Algumas escolas têm vivenciado a falta de muitos profissionais da educação. Embora o objetivo dele não seja a substituição de professores pelos bolsistas. Estes podem contribuir tanto na falta de professores como também levando novas práticas e caminhos 
aos professores que há muito tempo encontram-se na sala de aula (Aluno J).

Geralmente os Pibidianos trazem muitas ideias novas para implementar nas escolas junto as suas respectivas disciplinas, isso faz com que dê um ânimo nos alunos das escolas para estudar mais (Aluno E).

Nesta perspectiva podemos afirmar que diante da experiência já vivenciada pelos alunos bolsistas do PIBID "espera-se, pois, que mobilizem os conhecimentos da teoria da educação e da didática necessários à compreensão do ensino" (PIMENTA, 2006, p.19), ressaltando a importância da teoria atrelada a prática. Os bolsistas sentem-se desafiados a identificar os déficits das ações realizadas e, consequentemente, investigar as atividades desenvolvidas no intuito de melhorá-las e, desta forma, alcançar os seus objetivos pedagógicos. Faz, também, com que percebam que o saber-fazer pedagógico é constituído por um processo contínuo de construção identidária (PIMENTA, 2006, p.19).

Em relação às contribuições que ainda podem ser dadas, vários alunos falaram sobre melhorar a estrutura e a utilização do laboratório de Informática nas escolas, ou seja, como disse o Aluno D, "tornar o laboratório de Informática funcional". Isso vai possibilitar aos alunos de cada escola um maior aprendizado das várias disciplinas que cursam e aos professores a possibilidade de usar adequadamente ferramentas alternativas para tornar suas aulas ainda mais atrativas. Em resumo, transformar a Informática em uma ferramenta de pesquisa e estudos, e não apenas de entretenimento. 0 depoimento do Aluno K apresenta esse pensamento, que é geral entre os bolsistas:

A otimização da sala de Informática deixou o layout mais agradável e limpo. Ainda não concluímos nossa atuação, mas temos por objetivo que os alunos possam usar as ferramentas computacionais de forma independente e consciente, e que vejam o computador como um leque de possibilidades (Aluno K).

Percebe-se que os licenciandos têm uma preocupação com relação ao ambiente da sala de Informática, entretanto o objetivo principal está em como os alunos irão utilizar de forma responsável as tecnologias disponíveis nesse ambiente. Para Rosmann, Benevutti e Facenda (2014, p.100), “o educador deverá estar preparado para atuar com sujeitos que são nativos digitais, com condições socioeconômicas que permitem a aquisição de equipamentos, bem como aqueles, historicamente marginalizados, que não têm condições de acesso à cidadania". Os bolsistas do PIBID estão inseridos em escolas públicas que comportam alunos em sua maioria com baixas condições socioeconômicas, o que para eles é um desafio constante no que se refere a despertar o interesse do aluno para a educação tecnológica, bem como em parceria com as disciplinas que compõem o currículo escolar.

\section{CONCLUSÕES}

As ações realizadas pelos bolsistas licenciandos em Informática têm proporcionado significativas tentativas de relação entre teoria e prática na formação inicial dos bolsistas com constituição dos saberes pedagógicos. Diante das observações realizadas pelos bolsistas em relação aos aprendizados, como foi destacado nos depoimentos, identifica-se a relevância da vivência destes na realidade escolar. Como disserta Freitas (2010, p. 34), isso "tem confirmado e demostrado a justeza destes cuidados em relação às vivências imediatas da realidade escolar, de modo a evitar as consequências diretas que se traduzem no pragmatismo e no ativismo pedagógico".

O contato com o espaço escolar e, principalmente, com os alunos reflete a essência do ser docente. Rosmann, Benevutti e Facenda (2014, p. 107) definem uma concepção sobre o sentido de ensinar e de aprender, afirmando que: “[...] significa aprender a aprender. Ensinar, apenas não é mais possível, é preciso estimular a aprendizagem do outro e aprender com ele". Neste aspecto, podemos considerar que as contribuições são mútuas, enquanto os bolsistas vivem a sua graduação e desenvolvem ações junto às escolas, estão numa busca constante pelo aperfeiçoamento de suas metodologias de ensino para tornar o seu ensino significativo tanto para os seus alunos, quanto para si.

Pode-se dizer que o PIBID na Licenciatura em Informática tem contribuído para a formação inicial de professores, como comprovam os depoimentos dos bolsistas, mesmo com os impasses vivenciados na ausência do licenciado em Informática na escola pública. Nessa experiência, constrói-se um espaço de atuação para o Licenciado em Informática e mostra-se a necessidade desse profissional, uma vez que as escolas públicas pesquisadas possuem laboratórios para a ação dos licenciados. 
Permitir aos bolsistas a sua inserção na escola pública também integra os conhecimentos vivenciados no decorrer do Curso de Licenciatura em Informática do IFRN. Significa dizer que ao inserir os licenciandos no cotidiano de escolas, tem-se a oportunidade de vivenciar experiências metodológicas, tecnológicas e práticas docentes que permitem a superação de situações identificadas no processo de ensinoaprendizagem. Nesse caso, os bolsistas podem constituir uma formação inicial qualificada, para que desde a graduação possam pensar sobre as possibilidades de refletir sobre a prática docente na construção de sua profissionalização. O PIBID também tem um compromisso com a mudança da realidade da escola pública, que em determinadas realidades tem seus laboratórios pouco usados ou mesmo com utilização inadequada, quando consideramos esse espaço como uma possibilidade de apropriação de conhecimentos de maneira significativa para emancipação social.

\section{REFERÊNCIAS}

[1] ALMEIDA, C. C. CARVALHO, L. P. A formação de professores no curso de Licenciatura em Computação: um relato das práticas educacionais de iniciação a docência. Anais do XVIII Workshop de Informática na Escola. ISSN 2316-6541. Rio de Janeiro: SBC, 2012. ALMEIDA, Patrícia Cristina Albieri de. BIAJONE, Jefferson. Saberes docentes e formação inicial de professores: Implicações e desafios para as propostas de formação. Educação e Pesquisa, São Paulo, v.33, n.2, p.281-295, maio/ago. 2007.

[2] FREITAS, Helena Costa L. de. O trabalho como princípio articulador na prática de ensino e nos estágios. Campinas, SP: Papirus, 2010.

[3] GHEDIN, E., Almeida, M. I. and Leite, Y. U. F. (2008). Formação de Professores: Caminhos e Descaminhos da Prática. Liber Livro, Brasília.

[4] PIMENTA, Selma Garrido. Trabalho e Formação de professores: saberes e identidade. Passo Fundo, RS: UPF, 2006.

[5] RosmanN, Márcia Adriana. BENVEnUTTI, Leonardo Matheus Pagani. FACENDA, Luisa Cadorim. Dimensão(ões) da prática docente nas Licenciaturas: Constituição identidária e leituras de Paulo Freire. Passo Fundo RS, Méritos Editora, 2014.

[6] SHULMAN, L. S. Knowledge and Teaching: Foundations of the New Reform. Harvard Educational Review, 57 (I), p. 1-22, 1987.

[7] TARDIF, Maurice. Saberes docentes e formação profissional. 14. Ed.- Petrópolis, RJ: Vozes, 2012.

[8] _ _ Saberes docentes e formação profissional. Petrópolis, RJ: Vozes, 2002. 


\section{Capítulo 6}

\section{A importância do profissional licenciado em informática na rede pública de ensino e sua valorização por meio do PIBID}

\section{Janiele da Siva Costa}

Givanaldo Rocha de Souza

Francisco das Chagas da Silva Junior

Pauleany Simões de Morais

Resumo: 0 PIBID é um programa de política pública educacional cuja finalidade é o fomento da iniciação à docência, contribuindo para o aperfeiçoamento da formação de docentes e para a melhoria da qualidade da educação básica pública brasileira. Este artigo relata a experiência de um ano de atividades realizadas em uma escola pública estadual de Natal/RN por alunos do Curso de Licenciatura em Informática do IFRN, como bolsistas do PIBID. 0 objetivo é destacar a importância do profissional licenciado em Informática nas escolas públicas e a valorização desse profissional por meio do PIBID. Como metodologia, foram desenvolvidos diagnósticos de software, hardware e infraestrutura do laboratório, como forma de iniciar a atuação. Em seguida, foram elaborados cursos de formação direcionados para os alunos. Como resultados, notou-se um maior interesse dos alunos em frequentar o laboratório, assim como da gestão da escola em melhorar a infraestrutura do mesmo.

Palavras-chave: PIBID, Formação Docente, Políticas Públicas 


\section{INTRODUÇÃO}

A Informática está a cada dia mais presente no cotidiano, modificando a rotina e o comportamento das pessoas. Sendo assim, formar pessoas capazes de dominar a técnica para fazer uso dessa tecnologia e capazes também de realizar significativamente a utilização das informações proliferadas com os avanços científicos e tecnológicos se torna imprescindível, pois é cada vez mais comum que esta formação seja critério fundamental para que o sujeito possa garantir seu espaço no mercado de trabalho (França, 2014), além de que o acesso às tecnologias da informação pode proporcionar liberdade social, geração de conhecimento e troca de informações, contribuindo com a melhoria na qualidade de vida de quem usufrui delas (Unibrasil, 2008).

Isso evidencia a necessidade do estudo da Informática nas escolas desde o Ensino Básico, permitindo o aprendizado contínuo, o que possibilita o aprofundamento nos conhecimentos mais complexos dos segmentos da Informática, Schena e Cruz (2013). Afinal, "o Brasil vem, desde o ano de 1993, tentando implantar, através de projetos de lei, a disciplina Informática no contexto escolar. 0 que ainda não ocorreu." (Câmara dos deputados apud Lacerda, 2012).

Segundo consta no Projeto Pedagógico do Curso Superior de Licenciatura em Informática do IFRN:

0 ensino dos conceitos de Informática na educação básica fornece o conhecimento necessário à formação do cidadão, tirando, inclusive, o receio e o ar misterioso que rodeia o computador. A introdução desses conceitos básicos nas escolas diminui a carga de ensino em Informática na educação superior. [...] Aliado aos conhecimentos pedagógicos, o conhecimento de Informática faz do professor um profissional muito relevante para o desenvolvimento de tecnologias da educação (IFRN, 2012).

Assim, podemos evidenciar a importância do profissional licenciado em Informática nas escolas públicas (Cysneiros, 2000 apud Borges, 2006), não apenas para ministrar as aulas de conhecimentos específicos da área, mas também para auxiliar os demais professores no uso desta tecnologia em suas aulas (Borges, 2006) tendo em vista que a Informática dispõe de diversos softwares educacionais que são ferramentas facilitadoras do aprendizado em todas as disciplinas. Além disso, esse profissional pode utilizar os laboratórios de Informática dessas escolas em sua totalidade, explorando da melhor forma possível todos os recursos disponíveis. Aproveitamento que geralmente não acontece pela falta de preparação e desmotivação dos professores presentes nas escolas (BORGES, 2006).

Com base na experiência vivenciada, percebe-se que um meio fundamental para que a escola e o governo valorizem esse profissional são as ações de transformações que os graduandos em Licenciatura em Informática desenvolvem nas escolas públicas através do subprojeto Informática do Programa Institucional de Bolsa de Iniciação à Docência (PIBID), de acordo com os proclames do Edital no 01/2014 MEC/CAPES/061/2013.

Com o relato e as interpretações de experiências vividas pelos graduandos da Licenciatura em Informática do Instituto Federal de Educação, Ciência e Tecnologia do Rio Grande do Norte (IFRN), Campus Natal Zona Norte, o objetivo é compreender a importância e conhecer como se dá a valorização do profissional licenciado em Informática na rede pública de ensino, por meio de ações desenvolvidas na escola, enquanto participantes do PIBID.

Este artigo está subdivido da seguinte maneira: a Seção 2 contém uma breve explicação do que se trata o PIBID. A Seção 3 é referente ao ambiente da experiência, ou seja, nela é feita a apresentação da escola pública onde ocorre a vivência relatada. Na Seção 4 está descrita a metodologia que foi utilizada para a realização de toda a experiência nesta escola. A Seção 5 evidencia a importância do licenciado em informática na escola pública. A Seção 6 trata-se de uma reflexão de como esse profissional é valorizado por meio do PIBID. Na Seção 7 estão as conclusões obtidas com a vivencia dessa experiência. Finalmente, na Seção 8 estão as referências bibliográficas.

\section{PIBID: FORMAÇÃO PRÁTICA DE LICENCIADOS}

O PIBID tem por finalidade o fomento da iniciação à docência, contribuindo para o aperfeiçoamento da formação de docentes em nível superior e para a melhoria da qualidade da educação básica pública brasileira, de acordo com a Portaria no 096, de 18 de julho de 2013, Anexo I, Art. 2o․ Ele oferece bolsas aos 
alunos de cursos presenciais que se dediquem ao estágio nas escolas públicas e que, quando graduados, se comprometam com o exercício do magistério na rede pública.

Com essa iniciativa, o PIBID faz uma articulação entre a educação superior (por meio das licenciaturas), a escola e os sistemas estaduais e municipais. A intenção do programa é unir as secretarias estaduais e municipais de educação e as universidades públicas, a favor da melhoria do ensino nas escolas públicas em que o Índice de Desenvolvimento da Educação Básica (IDEB) esteja abaixo da média nacional. Entre as propostas do PIBID, está o incentivo à carreira do magistério nas áreas da educação básica com maior carência de professores com formação específica (MEC, 2017).

No Campus Natal - Zona Norte do IFRN o PIBID foi inserido no curso de Licenciatura em Informática no ano de 2012. 0 subprojeto intitulado "Proposta de Formação Docente Integradora: A Práxis Pedagógica no IFRN / Natal - Zona Norte e nas Escolas Parceiras" conta com a coordenação de 2 (dois) professores do curso de Licenciatura, 30 (trinta) alunos bolsistas de iniciação à docência e 2 (dois) professores supervisores sendo um em cada escola participante do projeto. Foram selecionadas 3 (três) escolas públicas da esfera estadual, localizadas na Zona Norte de Natal, são elas: a Escola Estadual Ana Júlia de Carvalho Mousinho (Escola 1), a Escola Estadual Walter Duarte Pereira. (Escola 2) e a Escola Estadual Antônio Fagundes (Escola 3).

\section{AMBIENTE DA EXPERIÊNCIA}

A experiência relatada neste artigo aconteceu na escola Estadual Walter Duarte Pereira, que está localizada na Avenida Blumenau, S/N - Potengi, 59112-410, Zona Norte da cidade de Natal/RN. Funciona em três turnos: matutino, vespertino e noturno, oferecendo o Nível Fundamental, Médio e Educação de Jovens e adultos (EJA). Esta escola enfrenta uma realidade crítica quanto ao Índice de Desenvolvimento da Educação Básica (IDEB), apresentando nos últimos anos uma média abaixo da nacional.

A escola participa do PIBID recebendo os subprojetos de informática, Matemática e Geografia, em cada um atuam dez bolsistas do programa estudantes de licenciatura na área respectiva ao subprojeto no Instituto Federal de Educação, Ciência e Tecnologia do Rio Grande do Norte. Dessa forma, totalizando trinta bolsistas do PIBID em atuação na escola Estadual Walter Duarte Pereira.

\section{METODOLOGIA DE ATUAÇÃO}

No primeiro contato com a Escola Estadual Walter Duarte Pereira, houve a apresentação dos graduandos bolsistas do PIBID, assim como do espaço físico geral da escola e também do laboratório de Informática. Foram enviados dez bolsistas do PIBID para atuar nesta escola, estes formaram duplas para realizar as atividades docentes. No total formaram-se cinco duplas que trabalham em horários e dias diferentes em todos os turnos atendendo a todos os públicos da escola, visto que a escola atua no Ensino Fundamental, Médio e Educação de Jovens e Adultos.

Nas primeiras etapas foram realizados pelos bolsistas os diagnósticos de software, hardware e da estrutura física do laboratório. No diagnóstico de hardware foi feito o levantamento de quantos computadores estavam instalados no laboratório e se apresentavam defeitos que impedissem as atividades que futuramente seriam desenvolvidas utilizando essas máquinas, além do levantamento das condições de uso dos periféricos, como teclado, mouse, etc. No diagnóstico de software foi feito o levantamento de quais softwares estavam instalados nas máquinas.

Como resultado do diagnóstico de hardware, o laboratório possui 10 computadores multiterminais, permitindo que 20 alunos participem das atividades desenvolvidas. A solução multiterminal funciona da seguinte maneira:

0 multiterminal consiste em ligar vários terminais compostos por monitores e seus respectivos teclados e mouses em um único gabinete. Assim, o conjunto de terminal ou multiterminal pode ser utilizado por inúmeras pessoas simultaneamente e independentemente. 0 multiterminal funciona da seguinte maneira: através de um programa de computador que foi baseado em uma função do GNU/Linux, todos os monitores, teclados e mouses são ligados ao gabinete e configurados de modo que possam ser usados independentemente e simultaneamente por inúmeras pessoas.

Com o diagnóstico, foi identificado nas máquinas o sistema operacional Linux Educacional na versão 4.0 e os diversos softwares educacionais que vem em seu pacote de instalação. 
Tendo os diagnósticos das condições do laboratório da escola em mãos, partiu-se para o planejamento das aulas. Foi elaborado por cada dupla um plano de curso que estabelecia os conteúdos que seriam ministrados em aula, o público alvo, ou seja, se seriam os alunos da escola, os professores e demais servidores ou se estaria aberto para a comunidade. Este definia também a carga horária dos cursos, os dias da semana e o horário que seriam ministrados. Os planos de cursos foram apresentados aos coordenadores de área do subprojeto Informática do PIBID do IFRN - Campus Zona Norte para obter aprovação. Em seguida, estes planos foram submetidos também à aprovação da direção da escola.

Terminado todo o processo de diagnóstico dos laboratórios, de elaboração e aprovação dos planos de cursos, deu-se início ao processo de matrículas para preenchimento das vagas dos cursos que se iniciariam. Logo em seguida, foram iniciadas as aulas de Informática Básica.

\section{A IMPORTÂNCIA DO PROFISSIONAL LICENCIADO EM INFORMÁTICA NA ESCOLA PÚBLICA}

No quadro de professores da escola Walter Duarte Pereira não há um profissional licenciado em Informática ou em Computação. Logo, não foi possível contar com um professor com esta formação para supervisionar o trabalho dos bolsistas na escola. Sendo assim, um professor com formação em Língua Portuguesa que também é o atual diretor da escola assumiu o cargo de supervisor do PIBID. Este ocorrido é uma exceção, pois para cada subprojeto é imprescindível a supervisão de um professor da escola com formação especifica, como ocorre com os demais subprojetos (Geografia, História, Matemática, etc.), inclusive nesta escola.

Isso gera uma dificuldade para o andamento das atividades desenvolvidas pelo o fato do diretor não ter tempo para atender as necessidades dos bolsistas em atividade na escola, já que suas responsabilidades são vastas e também não dispor de conhecimentos da formação especifica para que possa sanar qualquer dificuldade ou dúvidas dos bolsistas, tendo em vista que estes estão de forma prática estagiando na escola e ainda não são profissionais formados. Apesar de dificultar, esse contratempo não impediu que o trabalho fosse realizado da melhor maneira possível e que apresentasse resultados satisfatórios.

Ao chegar ao laboratório da escola, foi constatado que este raramente era utilizado pelos professores e quando isso não acontecia encontrava-se fechado e empoeirado. Quando os professores chegavam a esse ambiente da escola, não faziam uso em sua totalidade dos recursos educacionais que o laboratório dispõe, chegando a utilizar apenas o projetor multimídia para assistir algum vídeo, descartando completamente o uso do computador e de outros recursos da informática que são ferramentas poderosas para auxílio do aprendizado.

Com o diagnóstico de software realizado pelos bolsistas, vários softwares educacionais desenvolvidos para todas as disciplinas no ensino básico foram encontrados instalados nos computadores. Além disso, tem-se o uso da Internet que é uma ferramenta de pesquisa muito vasta, onde se pode encontrar livros gratuitos, artigos científicos, etc. Esses recursos educacionais ficavam obsoletos pela falta de conhecimento por parte dos professores da existência desses e também por não saberem utilizar o computador, em grande parte nem mesmo no que diz respeito à informática básica.

A escola necessita de profissionais preparados e capacitados no domínio do uso da tecnologia para favorecer o processo de ensino-aprendizagem, Moura e Brandão (2013). Nesse contexto pode-se enxergar como é necessária a presença do licenciado em Informática/Computação na escola pública. Esse profissional possui o domínio da técnica necessária para a utilização de maneira correta das ferramentas pedagógicas disponíveis nos computadores e no laboratório em geral. Isso permite que ocorra uma mudança na situação atual de inutilização deste laboratório, tornando as ferramentas e o ambiente favoráveis para o processo de ensino-aprendizagem, tanto para os alunos quanto para o corpo docente.

0 trabalho do licenciado em Informática/Computação em parceria com os professores das demais áreas do ensino básico promove a interdisciplinaridade que nos dias de hoje é condição fundamental do ensino (THIESEN, 2008) e auxilia esses professores quanto ao uso dos softwares educacionais em suas respectivas áreas, abrindo um novo leque de possibilidades utilizando essas ferramentas que podem atrair e prender a atenção dos alunos e melhorando a qualidade de suas aulas.

Além da parceria com os demais professores, o licenciado em informática está bem preparado no campo didático-pedagógico para a atuação docente efetiva na escola. Na realidade desta escola, poucos são os alunos que têm conhecimentos no campo da Informática que possam vir a trazer mudanças significativas em suas vidas, e a falta das aulas de Informática nas escolas prejudica os alunos tanto na formação crítica e empreendedora do cidadão (Unibrasil, 2008), quanto profissional, pois eles ficam muito aquém dos 
demais que possuem conhecimento (Schena e Cruz, 2013). Essas considerações ressaltam mais ainda a necessidade desse profissional na escola pública, sendo que este "[...] Aliado aos conhecimentos pedagógicos, o conhecimento de Informática faz do professor um profissional muito relevante para o desenvolvimento de tecnologias da educação" IFRN (2012).

\section{VALORIZAÇÃO DO LICENCIADO EM INFORMÁTICA POR MEIO DO PIBID}

Com a chegada dos bolsistas do PIBID na escola Walter Duarte Pereira já é possível observar transformações da situação encontrada no do laboratório da escola, situação essa já discutida na sessão anterior deste artigo. No momento que estavam sendo realizados os diagnósticos referentes às condições do laboratório, os bolsistas organizaram o ambiente detectando as máquinas, demais dispositivos e outros materiais que não estavam em condições de uso e em seguida separando-os dos demais facilitando posteriormente uma análise mais completa. Após isso foi feita uma reorganização da disposição dos computadores, armários e demais materiais em boas condições, isso proporcionou um melhor aproveitamento de espaço no ambiente. Por não existir um profissional responsável pelo laboratório, este se encontrava inadequado para exercer práticas docentes, além de estar sendo como dispensa para guardar materiais sem uso da escola.

Com essa atividade inicial dos bolsistas do PIBID, os funcionários e principalmente os alunos começaram a expressar curiosidade e desejo de utilizar o laboratório. Esse ambiente começou a ser enxergado pela escola e seus alunos como um ambiente com potencial para ser melhor aproveitado. Isso nos mostra que por meio do PIBID a escola começa a enxergar a necessidade do profissional capacitado para organizar e manter o laboratório em condições apropriadas de uso e a valorização deste profissional, visto que além de exercer a prática docente, "os licenciados em Informática poderão também atuar no planejamento e execução de currículos e programas de capacitação profissional, no desenvolvimento de materiais educacionais através do emprego da Informática e na organização e administração de laboratórios de Informática" (IFRN, 2012).

Com o início das matrículas para o preenchimento das vagas para formação das turmas dos cursos de informática básica, ministrados pelos bolsistas do PIBID, notou-se um grande interesse por parte dos alunos da escola em participar e todas as vagas foram preenchidas de imediato. Com o início das aulas era possível perceber a enorme curiosidade que os alunos demonstravam em aprender sobre esse universo da informática que tanto é falado nas mídias e na sociedade, mas que eles não tinham conhecimento suficiente para entender como funciona e de como utilizar essa tecnologia de forma a promover mudanças significativas em suas vidas, seja no âmbito profissional ou social. Mas para que isso ocorra é necessário que exista a oportunidade de acesso ao conhecimento, que na realidade desta escola os alunos não têm condições financeiras de pagar para adquiri-lo.

Contudo, para promover a inclusão digital e social não basta apenas democratizar os meios de acesso, saber utilizar a informação é um fator determinante no exercício da cidadania e da inclusão social (Borges, 2006). Com essa experiência proporcionada aos bolsistas e a escola pelo PIBID fica evidente a importância do papel que o licenciado em informática/computação exerce como mediador do conhecimento na escola pública, visto que, como já foi discutido neste artigo, este é capacitado em todos os aspectos para esta função.

Com o movimento de transformação que os bolsistas estavam realizando, o andamento dos cursos de Informática e o entusiasmo dos alunos em continuar participando do projeto e aprendendo mais a cada aula, a direção da escola demonstrou interesse em melhorar a infraestrutura do laboratório que, mesmo tendo sido melhorada com as atividades inicias dos bolsistas, ainda não é totalmente favorável ás atividades do projeto devido à climatização e instalação elétrica estarem ambas muito precárias.

\section{CONSIDERAÇÕES FINAIS}

Com esta experiência vivenciada como bolsistas do PIBID, conclui-se que o programa é essencial para a formação a docente, pois deixa os seus bolsistas de frente com a realidade das dificuldades enfrentadas na escola pública, de maneira a promover a reflexão sobre a responsabilidade de ser um profissional comprometido com sua missão.

Na escola onde é vivida a experiência, o subprojeto informática deste programa promoveu mudanças na organização de seu laboratório de informática, favorecendo que ocorra a aprendizagem significativa na área da informática fator primordial para que ocorra a inclusão digital e social, o que atraiu o interesse dos 
alunos em frequentar esse ambiente e participar dos cursos, além de despertar a direção da escola para a necessidade de melhorar a estrutura física do laboratório.

Conclui-se também o quão é importante que os futuros licenciados em Informática se dediquem também depois de formados a promover a inclusão digital e social na escola pública, visto que esta apresenta uma grande carência da presença deste profissional atuando e modificando essa realidade, dessa maneira contribuindo de forma significativa com a educação básica do nosso país.

\section{REFERÊNCIAS}

[1] BORGES, M. F. V. Inserção da informática no ambiente escolar: inclusão digital e laboratórios de informática numa rede municipal de ensino. In: Anais do IV Seminário Internacional Sociedade Inclusiva, p. 1-16, 2006.

[2] CAPES. Portaria № 096, de 18 de Julho de 2013. Disponível em: < https://www.capes.gov.br/images/stories/download/legislacao/Portaria_096_18jul13_A provaRegulamentoPIBID.pdf >. Acesso em: 10 mai. 2017.

[3] FRANÇA, R. S., et al. Disseminação do pensamento computacional na educação básica: lições aprendidas com experiências de licenciandos em computação. In: Anais do XXXIV Congresso da Sociedade Brasileira de Computação, p. 1473-1482, 2014.

[4] IFRN. Projeto Pedagógico do Curso Superior de Licenciatura Plena em Informática. Disponível em: <http://portal.ifrn.edu.br/ensino/cursos/cursos-de-graduacao/licenciatura/licenciatura-plena-eminformatica/view>. Acesso em: 24 abr. 2017.

[5] LACERDA, M. Informática como disciplina obrigatória na educação básica. In: Anais do IX encontro virtual de documentação em software livre e VII Congresso internacional de linguagem e tecnologia online, p. 1-10, 2012.

[6] MEC. PIBID - Apresentação. Disponível em: < http://portal.mec.gov.br/pibid>. Acesso em 16 abr. 2017.

[7] MOURA, E.; BRANDÃO, E. O uso das tecnologias digitais na modificação da prática educativa escolar. Revista Fazer, v.1, p. 1-17, 2013.

[8] SCHENA, E. C.; MARCIA, E. J. K. A importância da disciplina de informática nas escolas públicas. In: Anais do IV Salão de Ensino e de Extensão, $2013 . \quad$ Disponível em: < http://online.unisc.br/acadnet/anais/index.php/salao_ensino_extensao/article/view/1123 6>. Acesso em: 10 jun. 2017.

[9] THIESEN, J. S. A interdisciplinaridade como um movimento articulador no processo ensino- aprendizagem. Rev. Bras. Educ. Med., v. 13, p. 1-12, 2008.

[10] UNIBRASIL. Projeto Informática Cidadã. Disponível <http://www.unibrasil.com.br/detalhe_categoria.asp?id=1095>. Acesso em: 13 abr. 2017.

em: 


\section{Capítulo 7}

Concepção de infância e as aulas de artes: reflexões a partir da experiência do Programa Institucional de Bolsas de Iniciação à Docência (PIBID) Artes Visuais UNESC/2012-2013

Juliana Pereira Guimarães

Silemar Maria de Medeiros da Silva

Resumo: 0 presente artigo faz-se a partir da pesquisa desenvolvida como Trabalho de Conclusão de Curso que teve como objetivo: Refletir sobre a concepção de infância e de que forma ela auxilia no trabalho de artes com crianças, a partir das experiências do Pibid de Artes Visuais da UNESC. A investigação aconteceu com os acadêmicos bolsistas do Pibid de Artes visuais que estavam cursando diferentes fases do curso e a partir de estudos dirigidos dentro do programa fomentaram a necessidade de compreender as questões que permeiam a criança/infância. Como problema tem-se: investigar sobre o que dizem os acadêmicos bolsistas do Pibid de Artes Visuais sobre concepção de infância e de que forma esse dizer auxilia no trabalho de artes com crianças. Para elucidar melhor o problema o diálogo acontece a partir de um referencial teórico pertinente o qual dialoga com Kramer (2006), Leite (2007), PCNs (BRASIL,1998a), Ariés (1981), Pilloto (2007), entre outros. Abordando temas como formação dos professores de artes visuais, ensino da arte e seu percurso, a criança e a concepção de infância. As experiências do Pibid de Artes Visuais que contam da infância serão contempladas no exercício da reflexão pontuadas no problema dessa pesquisa. Trata-se de uma pesquisa qualitativa, somada a um estudo de caso que estuda profundamente um objeto permitindo seu amplo e detalhado conhecimento. Durante a análise dos dados a evidência fica por conta da reflexão sobre as contribuições do Pibid, em específico as discussões sobre concepção de infância na formação dos licenciandos, como um saber importante para a qualidade das aulas de artes com crianças.

Palavras-chave: Pibid de Artes Visuais. Ensino da Arte. Formação de Professores. Infância. Artes Visuais. 


\section{INTRODUÇÃO}

O presente texto tem origem no Trabalho de Conclusão de Curso apresentado em 2013 no Curso de Artes Visuais Unesc por Juliana Guimarães. Pesquisa orientada pela professora Silemar Silva. 0 título desse texto é o título do TCC. Portanto trata-se de uma pesquisa concluída que será aqui apresentada em quatro mãos.

Participamos de uma experiência bastante significativa juntas, que ampliou nosso repertório de conhecimento sobre arte e seu ensino, falamos aqui do Programa Institucional de Bolsa de Iniciação à Docência - Pibid, programa que tem como proposta estreitar cada vez mais a relação entre a Universidade e a escola. Esse programa é desenvolvido nas Universidades do Brasil desde 2007, na UNESC iniciou suas atividades no segundo semestre de 2012, com a aprovação no Edital Pibid no. 11/2012 CAPES Coordenação de Aperfeiçoamento de Pessoal de Nível Superior (BRASIL,2012). A atuação da área de artes aconteceu no período de 2012 e 2013, na Escola Municipal de Ensino Fundamental Dionizio Milioli no bairro Ana Maria na cidade de Criciúma - SC. E é sobre essa experiência que esse texto se concentra.

O Pibid de Artes Visuais, em seu formato possui um coordenador institucional, um coordenador de área, um professor supervisor e dez bolsistas do Curso de Artes Visuais. Um programa que proporcionou o contato com planejamentos das aulas de artes nos permitindo a reelaboração dos mesmos com constantes reflexões evidenciando a situação da escola. Os encontros do grupo do Pibid foram provocando mudanças no olhar também sobre as crianças e sua forma de se relacionar com o outro, com o mundo e com a arte. Essas mudanças desencadearam o interesse em realizar um estudo mais aprofundado sobre a experiência que é a participação no cotidiano escolar, à relação das múltiplas infâncias e as práticas docentes do professor de artes, neste caso, com as crianças. 0 interesse por esse tema começou em uma das atividades do Programa, momento em que o grupo escreveu sobre o que entendiam por concepção de infância. Ao analisar as respostas, constatamos que havia ainda, uma visão distorcida sobre essa concepção. Algumas ações foram realizadas nesse sentido e ampliaram-se os conceitos do grupo, mas ainda com questionamentos pertinentes.

A partir dessas questões, o problema de pesquisa se desenhou como: investigar sobre o que dizem os acadêmicos bolsistas do Pibid de Artes Visuais sobre concepção de infância e de que forma esse dizer auxilia no trabalho de artes com crianças. O desafio se amplia fomentando alguns questionamentos como: o professor de Artes Visuais está preparado para receber as crianças? Como a compreensão da concepção de infância pode influenciar no planejamento das propostas pedagógicas do professor de Arte? Qual a importância do conhecimento sobre as concepções de infância para o professor de Arte?

Com o objetivo de: Refletir sobre a concepção de infância e de que forma ela auxilia no trabalho de arte com crianças, a partir das experiências do Pibid de Artes Visuais da UNESC. A pesquisa é um instrumento indispensável para construção do saber, neste sentido, encontramos assim, a relevância desta proposta, ou seja, ampliar olhares sobre a infância para assim poder melhor trabalhar com ela, no sentido de contribuir cada vez mais para a qualidade da educação sendo ela de arte ou não.

\section{PERCURSO PERCORRIDO}

Para tratar das questões metodológicas dessa investigação, tomamos como referência o conceito de pesquisa pontuado por Zamboni (1998, p. 43), qual seja: "A busca sistemática de soluções, com o fim de descobrir ou estabelecer fatos ou princípios relativos a qualquer área do conhecimento humano". Esta busca fica evidente através do interesse em ampliarmos o conhecimento sobre este tema. Sendo assim, a partir da atitude de investigação foi necessário realizarmos um levantamento bibliográfico, somado a um estudo de caso que consiste segundo Gil (2002, p. 59) como sendo “[...] caracterizado pelo estudo profundo e exaustivo de um ou de poucos objetos, de maneira que permita o seu amplo e detalhado conhecimento, tarefa praticamente impossível mediante os delineamentos considerados".

Esta proposta envolveu a escrita e a fala dos acadêmicos bolsistas sobre concepção de infância ${ }^{4}$. E está inserida na linha de pesquisa do Curso de Artes Visuais: Educação e Arte. Linha esta, que traz como ementa "os princípios teóricos metodológicos sobre educação e arte, estudos sobre estética, semiótica, identidade, cultura e suas implicações sobre arte educação" (UNESC,2012a, p.38).

\footnotetext{
${ }^{4}$ A pesquisa foi realizada com os nove bolsistas, que estavam no programa na data da pesquisa, Juliana era a de número dez que não participou pois se colocou como pesquisadora, participaram também cinco bolsistas que foram substituídos somando então quatorze participantes.
} 
Como instrumento de coleta de dados foi aplicado um questionário com os acadêmicos bolsistas do Pibid. Para tratar das questões metodológicas dessa investigação, tomamos como referência o conceito de pesquisa pontuado por Zamboni (1998, p. 43), qual seja: "A busca sistemática de soluções, com o fim de descobrir ou estabelecer fatos ou princípios relativos a qualquer área do conhecimento humano". Esta busca fica evidente através do interesse em ampliar o conhecimento sobre este tema. Foram 14 bolsistas que, com a aplicação de um questionário, atenderam à uma entrevista semiestruturada, pois a pesquisadora se fez presente nos momentos em que aplicava o questionário. Hora no próprio encontro do grupo, hora nos corredores da instituição (em específico com os que já haviam saído do grupo).

\section{PIBID, A ARTE E A SUA RELAÇÃO COM A CRIANÇA/INFÂNCIA}

A relação da arte com a capacidade de comunicação do ser humano é bastante estreita, uma vez que, o homem conquistou a capacidade de se comunicar, inicialmente com sons, gestos e a fala. Criou um conjunto de signos e símbolos, os quais formaram as linguagens. Falamos da arte como uma dessas linguagens, como afirma Martins, Picosque e Guerra (1998, p. 34) “[...] Antes mesmo de saber escrever, o homem expressou e interpretou o mundo em que vivia pela linguagem da arte". Desde os seus primórdios o homem produz arte, as diversas civilizações produziram códigos para se comunicar através das manifestações artísticas, seja por meio do grafite ou manifestações corporais. Sobre os desenhos dos homens primitivos, Vasconcellos (2006, p. 41) afirma que "[...] 0 esforço humano para ordenar e dar sentido ao universo encontrou nesta arte-magia primitiva um poderoso meio de ação. Por meio dela a imaginação humana podia se tornar concreta". Nesse sentido, a imaginação se torna uma característica humana e o homem então percebe uma tentativa de encontrar formas de se relacionar com o universo, de se comunicar.

De acordo com os Parâmetros Curriculares Nacionais (BRASIL, 1998a, p. 19) "Arte tem uma função tão importante quanto a dos outros conhecimentos no processo de ensino e aprendizagem. A área de Arte está relacionada com as demais áreas e tem suas especificidades". O desenvolvimento do conhecimento estético sofre constante transformação na forma do homem se relacionar com o mundo, possibilitando a criação de símbolos para representar, uma característica humana. A partir da ideia de que arte é linguagem. Martins, Picosque e Guerra (1998, p. 37) afirmam que "[...] Pode-se dizer que linguagem é um sistema simbólico e toda linguagem é um sistema de signos". Essas linguagens são verbais e não -verbais. As linguagens artísticas: dança música, teatro, artes visuais, entre outras, possuem sistemas de signos que são meios de expressão e comunicação.

Como uma das possibilidades de comunicação está o exercício da construção do olhar que promove a ampliação do repertório imagético. Funciona como uma janela ao qual o conhecimento sensível se amplia. Os estudantes ao se apropriarem desses conhecimentos desenvolvem a alfabetização estética, sendo assim, sobre a educação do olhar comungo com Ganzer (2005, p. 85) no dizer que "[...] uma construção na qual, a percepção e a sensibilidade estão imbricadas na produção do conhecimento. Tornar visível o que se olha é uma concepção da sensível". É no sentido de melhor compreender o ensino da arte na contemporaneidade que o Pibid planeja suas atividades, proporcionando a ampliação de conhecimento em diferentes lugares e espaços em que a arte se apresenta. Nesse cenário considera a criança como principal protagonista.

Na sequência evidenciamos o percurso do ensino da arte, o qual, se transformou conquistando seu espaço assegurado pelas leis, às inquietações de professores e pesquisadores da área são uma constante na busca de contribuir com a qualidade do ensino da arte e é com base nesse dizer que o Pibid de Artes Visuais constrói suas práticas. Partirmos assim, da ideia de que, quando a escolha profissional é a de ser professor, este é responsável pela construção do conhecimento, que ensina e aprende. Sendo que, nesta troca de saberes, a profissão vai se consolidando, porque por trás daquele que ensina tem um eterno aprendiz que constrói diariamente a sua carreira. Ao acessarmos nossa memória facilmente trazemos a lembrança dos professores pelos quais passamos, por exemplo.

É necessário, o conhecimento das competências e habilidades da área que escolhemos, construindo, assim, uma identidade profissional que não é fixa, que se constrói a cada experiência, através da sua relação com o mundo e com a construção do conhecimento. Comungando com Hall (2002, p. 13), ou seja, "[...] 0 sujeito assume identidades diferentes em momentos diferentes [...] de tal forma que nossas identificações estão sendo continuamente deslocadas". Sendo então, a identidade móvel, nesse sentido, o professor está em constantemente formação construindo suas práticas através das competências aliado a experiência e da relação com o outro. 
O professor não é o dono das verdades absolutas, o conhecimento no mundo contemporâneo muitas vezes é acessível através das tecnologias. Os desafios existem como em qualquer profissão, a desvalorização da classe além de um maior investimento nas políticas públicas em questões salariais é um problema que o país tem enfrentado. A valorização passa por buscar a realização de um trabalho de qualidade, os resultados são observados através da fala dos alunos, suas produções e desenvolvimento. 0 professor nunca estará pronto ou completo, sendo que o conhecimento é algo constante e contínuo na vida. A formação continuada é uma necessidade para que possamos estar sempre em contato com novas pesquisas da área, com trocas de experiências proporcionando aos estudantes sempre novos desafios. Nesse sentido os encontros de formação no Pibid têm proporcionado uma possibilidade de formação paralela à graduação -, fortalecendo assim, caminhos para um ensino da arte cada vez mais significativo que, entre outras coisas, toma a criança e (o adolescente) como centro dessa história.

A concepção de criança é, na maioria das vezes, cultivada no imaginário das pessoas como um ser humano que possui somente ingenuidade, que não consegue entender muitas coisas, e que sempre precisa de alguém, neste caso, o adulto para se expressar, cultivando um modelo ideal de infância a ser seguido. Existem características singulares de cada criança, conhecimentos produzidos sobre e para a infância desvelando os múltiplos olhares dessa condição de ser criança, e viver a infância. Encontramos nas Diretrizes Curriculares Nacionais para a Educação Infantil - DCNEI, uma definição de criança com o qual comungamos, qual seja:

Sujeito histórico e de direitos que, nas interações, relações e práticas cotidianas que vivencia, constrói sua identidade pessoal e coletiva, brinca, imagina, fantasia, deseja, aprende, observa, experimenta, narra, questiona e constrói sentidos sobre a natureza e a sociedade, produzindo cultura (BRASIL, 2010, p. 12).

Partimos desta definição sobre a criança que a evidencia enquanto sujeito que produz cultura e é produzido por ela, possuindo direito de escolha, fala e produção de ideias, que muitas vezes, o adulto, por não compreender, ignora-a impondo limites, induzindo o seu pensamento, reduzindo a sua possibilidade de autonomia. Encontramos em Cohn (2005, p. 19) uma questão importante que é a visão universal que se tem sobre a infância, ou seja, "[...] falamos aqui de uma antropologia da criança e não da infância. Isso porque a infância é um modo particular, e não universal, de pensar da criança".

Nas relações de transformações e dualidades nos estudos de Ariès (1981) sobre a ideia de infância comungo com Kramer (2006, p. 15), quando a mesma afirma que a infância "[...] foi marcada por um duplo modo de ver as crianças, pela contradição entre moralizar (treinar, conduzir, controlar a criança) e paparicar (achá-la engraçadinha, ingênua, pura, querer mantê-la como criança)". Muitas vezes, ainda está dualidade se coloca na fala de muitos professores quando se referem à criança. Sendo esta, considerada como categoria da história cidadã de direitos. No Brasil, a partir da Constituição Federal de 1988, a criança começa a ter a garantia dos direitos fundamentais de cidadãos assegurados como afirma no capítulo VII no artigo 227:

É dever da família, da sociedade e do Estado assegurar a criança e o adolescente com absoluta prioridade o direito à vida, à saúde, à alimentação, à educação, ao lazer, a profissionalização, à cultura, a dignidade, ao respeito, à liberdade e a convivência familiar e comunitária, além de colocá-los a salvos de toda forma de negligência, discriminação, exploração, violência, crueldade e opressão (BRASIL, 1988).

Em 1990, é criado o ECA (lei no. 8.069) que afirma os direitos da criança e as protege como consta no capítulo IV Art. 58: "No processo educacional respeitar-se-ão os valores culturais, artísticos e históricos próprios do contexto social da criança e do adolescente, garantindo-se a estes a liberdade da criação e o acesso às fontes de cultura" (BRASIL, 1990a).

A Lei de Diretrizes e Bases 9394/96 (BRASIL, 1996) no título III, artigo 4, reconhece a educação infantil como à primeira etapa da Educação Básica, sendo a mesma, direito da criança e dever do Estado. A Convenção sobre os Direitos da Criança, aprovada pela Organização das Nações Unidas (ONU) em decreto no. 99.710 de 1990, art.13, afirma que:

A criança terá direito à liberdade de expressão. Esse direito incluirá a liberdade de procurar, receber e divulgar informações e ideias de todo tipo, independentemente de fronteiras, de forma oral, escrita ou 
impressa, por meio das artes ou por qualquer outro meio escolhido pela criança (BRASIL, 1990b).

Assim, a criança tem seus direitos assegurados pelas leis. Compreendendo que a concepção de infância é uma construção social, pois não há um único modelo familiar e de sociedade, então a ideia que associamos a criança somente com o brincar, liberdade, estudar, estar com a família, é um direito seu, mas nem sempre é dessa maneira em que ela se configura. De acordo com Kramer (2006, p. 15), faz-se necessário reconhecer o que é específico da criança, uma vez que:

A criança não se resume a ser alguém que não é, mas que se tornará (adulto, no dia em que deixar de ser criança). Reconhecemos o que é específico da infância: seu poder de imaginação, a fantasia, a criação, a brincadeira entendida como experiência de cultura. Crianças são cidadãs, pessoas detentoras de direitos, que produzem cultura e são nela produzidas. Esse modo de ver as crianças favorece entendê-las e também ver o mundo a partir de seu ponto de vista. A infância, mais que estágio, é categoria da história: existe uma história humana porque o homem tem infância.

Quando falamos de criança, compreendemo-la enquanto alguém com a idade de 0 a 12 anos de acordo com o ECA - Estatuto da Criança e do Adolescente (BRASIL,1990a) sendo algumas características inerentes a cada faixa etária. Partindo da ideia de que cada um possui seu desenvolvimento e formas de se comunicar com o mundo, com o outro e com a arte, defendemos aulas de arte que se façam enquanto um convite à imaginação. Muitos dos elementos ou códigos das artes visuais estão presentes no cotidiano da vida infantil, como afirma o Referencial Curricular Nacional para a Educação Infantil - RCNEI (BRASIL, 1998b, p. 85) a criança experimenta elementos da arte para expressar experiências sensíveis "[...] ao rabiscar e desenhar no chão, na areia e nos muros, ao utilizar materiais encontrados ao acaso, como gravetos, pedras, carvão, ao pintar objetos e até mesmo seu próprio corpo".

Nesta perspectiva, partimos da compreensão sobre as questões que permeiam o cotidiano infantil é que as aulas de arte devem ser construídas com as crianças, sendo a participação uma característica efetiva proporcionando autonomia, criatividade e expressão. 0 relacionamento da criança com as linguagens além de ampliar o seu conhecimento consequentemente desenvolve a sua relação com o outro e com o mundo.

Diante disto, as aulas de Arte com crianças devem ser construídas com experiências vivenciais, de forma lúdica, envolvendo a brincadeira, propiciando às crianças criar e recriar suas percepções através da imaginação, representando e se comunicando. A proposta de um ambiente de ensino interessante para elas é importante para iniciar um diálogo significativo com as crianças. A expressão e a sensibilização contribuem, através da experimentação artística, no desenvolvimento do potencial criador. Comungamos com Pilloto $(2007$, p. 24) sobre o fazer criativo das crianças, "[...] sempre se desdobra numa simultânea exteriorização e interiorização das suas experiências, numa compreensão cada vez maior de si própria e numa constante abertura de novas perspectivas do ser".

Para que o fazer criativo aconteça de forma significativa, é necessário, oportunizar diferentes espaços e também materiais, proporcionando o acesso às diferentes linguagens em que a arte se apresenta, o professor deve planejar propostas metodológicas com fundamentos envolvendo os pressupostos como afirma Pilloto, Pereira e Ropelato (2009, p. 75) "[...] ludicidade, jogos e brincadeiras, articulação entre as linguagens e expressões artísticas, processos de leituras, vivências com diferentes suportes e materiais [...] contextualização histórico-cultural e produção de sentidos".

Não há uma receita para lecionar arte com crianças, porém, é necessário além de saber arte, compreender características peculiares de cada faixa etária, conhecer o perfil da turma, prestar atenção na fala das crianças que evidenciam os seus interesses, é necessário provocar o olhar, o gosto, o cheiro, a percepção, partir de propostas dinâmicas com experiências vivenciais. Desta forma, o Pibid propõe em suas discussões reflexões acerca da prática do ensino de arte com crianças. 0 Pibid de Artes Visuais de que narramos fez-se enquanto um subprojeto do Pibid da UNESC e iniciou suas atividades com o objetivo assim traçado:

Este subprojeto Pibid pretende oportunizar aos licenciandos do curso de Artes Visuais sua inserção no cotidiano das escolas públicas da cidade de Criciúma/SC integrantes deste projeto, afim de que possam aproximar as ênfases dadas no curso com as necessidades da escola, em termos de ensino, por meio de ações que os insiram/envolvam no universo da 
docência. Assim como contribuir para a reflexão crítica das práticas dos professores das escolas envolvidas (UNESC, 2012b, p.1).

Foi nesta perspectiva, que o grupo com os dez bolsistas aprovados por meio de entrevista iniciaram suas atividades no programa. As atividades se iniciaram com reuniões para definição das propostas a serem desenvolvidas na E.M;E.I.E.F. Dionízio Milioli. Nossa ação envolveu realizar o trabalho junto a crianças de 1 o ao $5^{0}$ ano levando em conta que algumas atividades envolvem a participação de toda a escola. Em função do trabalho com essa faixa etária, o programa proporcionou aos licenciandos várias experiências em que leituras, pesquisas e discussões sobre a infância se fizeram necessário uma vez que o desafio era a participação, ação e autonomia das mesmas e que as aulas de arte se tornassem cada vez mais dinâmica e produtiva promovendo através do lúdico, imaginação, criação e expressão uma estreita relação entre a criança e a arte. A pesquisa se propõe a ouvir esses bolsistas, nesse sentido. Sobre a pesquisa de campo, conforme mencionado no início do texto, quatorze bolsistas foram entrevistadas, nove que estão atualmente no programa e cinco que já saíram, sendo que estes são de fases diferentes ( $88^{a}, 7 \underline{a}$, 4 a e $3^{a}$ a fase $)$ do Curso de Artes Visuais - UNESC. O intuito aqui, é analisar os dados coletados, com o objetivo de investigar o que dizem os acadêmicos bolsistas sobre a concepção de infância para então refletir sobre a importância desse tema na formação do professor, em específico do professor de arte. Todos os acadêmicos autorizaram a utilização dos seus nomes e a partir do que foi acordado com eles, as respostas foram mantidas conforme a escrita de cada um.

A criança é um ser em pleno desenvolvimento e a escola precisa assumir um papel mediador no progresso intelectual da mesma, portanto, nós professores, ao optarmos por uma concepção pedagógica que norteia a nossa prática, assumimos o compromisso com a construção da sociedade. 0 conhecimento constitui-se das produções humanas, histórica e culturalmente produzidas, através das interações sociais, dessa forma, o conhecimento não é pronto e acabado, mas que constantemente se transforma. A concepção de infância é uma noção historicamente constituída, ou seja, o sentimento de criança e infância, que é determinado pelas interações sociais, vem mudando ao longo dos tempos. Precisamos conhecer a criança com quem trabalhamos, compreendendo-a como um ser social e histórico e que tem diversas realidades, econômicas, culturais e raciais. Esta concepção de infância contrapõe-se à ideia muito presente no senso comum de que a criança pode ser manipulada, pois não possui opinião própria, ou mesmo ser incompleto que deve ser preparado para se tornar adulto.

A criança age no mundo sempre de forma mediada pelos instrumentos materiais e pelos significados que os adultos fornecem as suas ações. As atividades desenvolvidas pelas crianças são quase sempre compartilhadas pelos adultos, que interagem com elas. Trata-se, de um processo construído através da mediação de seres mais experientes da sua cultura, permitindo que a criança ao longo do seu desenvolvimento, transforme funções que realizava inconscientemente em funções operacionalizadas de forma autônoma ao longo do seu desenvolvimento até a vida adulta.

Com o objetivo de investigar o que dizem os acadêmicos bolsistas sobre a concepção de infância para então refletir sobre a importância desse tema na formação do professor, a classificação das respostas foram apresentadas por grupos sendo que o A representa os que participaram do programa deste o seu início - incluindo os que foram substituídos, com relação a esse grupo, considero as respostas da pergunta formulada pela coordenadora de área, ainda em 2012, referente ao que é ser criança para eles? Além de considerar também o questionário que apliquei com todos que participam atualmente. Neste caso faz-se uma análise comparativa entre a primeira resposta e a segunda, o que não foi possível fazer com o grupo B. 0 qual representa os que entraram no decorrer do programa. Com relação a esse grupo, só foi analisado as respostas das questões para essa pesquisa.

No questionário haviam as seguintes questões: Para você o que é ser criança? Como podemos conceituar a infância nos dias de hoje? Como você percebe o trabalho do Pibid com relação a criança/infância? 0 grupo A ao responder a primeira pergunta apresenta dois tipos de resposta: Com relação ao primeiro bolsista, o mesmo respondeu (em 2012): "Ser criança é viver intensamente, sem malícia com a vida com as coisas do cotidiano. É brincar, criar, inventar, imaginar e assim fazer do dia a dia uma enorme brincadeira". Quando retomada a pergunta no questionário (em 2013), ele respondeu:

É imaginar, brincar, ser limpo nos pensamentos, livre no corpo. É questionar o mundo e ser tocado pelas respostas. Lembro das aulas onde ensaiamos o canto do boi, a empolgação em conhecer as músicas, e lembro também do quanto foi mágico ver as crianças brincando com os bichos, e assim vivenciando um momento de descoberta. 
Na primeira resposta o bolsista descreve um conceito de criança idealizado, quando a questão é retomada a fala ainda persiste, a criança com pensamentos ingênuos e muita liberdade, porém menciona as aulas de arte e a participação das crianças em uma das atividades propostas pelo Pibid que foi a restauração do Boi de Mamão como um momento no qual chamou a sua atenção para a manifestação e entusiasmo das crianças. O que comunga com o dizer de Pilloto (2007, p. 26) quando afirma que "[...] as crianças se desvelam e revelam-se por meio das manifestações expressivas. Materializam em formas, movimentos, sons os repertórios que vão se apropriando de um universo de histórias, situações e percepções". Sendo assim, na segunda resposta, a expressão revelou o entusiasmo e o modo singular como cada criança se expressou quando foi permitido brincar com os personagens do Boi de mamão.

O segundo bolsista respondeu (em 2012):

Ser criança é entender tudo de um modo simplificado sem confusão, É ser sincero. Ser criança é brincar de ser gente grande e às vezes viver isso, prestar atenção nos adultos e imitar, hoje até pode ser que as crianças brincam menos na rua, mas era tão bom brincar de se esconder, pega - pega, casinha. Ser criança é ter direitos e deveres.

Quando retomada a pergunta no questionário aplicado recentemente (2013), respondeu: "Percebo que a infância está em extinção, à inocência foi embora, o ser infantil está acabando aos poucos".

Na primeira resposta o bolsista descreve a criança como alguém que entende tudo e é sincera, que vive uma vida de adulto, neste sentido encontro em Cohn $(2005$, p. 28) razões para compreender melhor o papel social da criança "[...] Reconhecê-lo é assumir que ela não é um adulto em miniatura, ou alguém que treina para a vida adulta". A lembrança da infância é descrita como um momento bom, há uma compreensão que a criança possui direitos e deveres, porém na segunda resposta, coloca a infância como algo que está acabando, fica claro uma comparação com a infância vivida, porém não há como comparar os contextos e as questões sociais em que cada criança vive.

Respondendo a primeira pergunta o grupo B dos bolsistas que entraram no decorrer do programa e que não participaram das primeiras discussões trazem suas contribuições a partir das seguintes respostas:

A primeira bolsista respondeu que:

Ser criança é desenvolver-se em seu caráter e seu psicológico, é produzir conhecimento e aprender ao mesmo tempo. A criança hoje é diferente da criança de 20 anos atrás, ela vive em um tempo diferente, cultura diferente, portanto são crianças tornando-se adultas em menos tempo e com menos responsabilidades ou com diferentes responsabilidades, que as crianças de 20 anos atrás vivenciaram.

A bolsista descreve a criança como produtora de conhecimento, compara a criança de hoje com há de vinte anos atrás, sendo que nenhuma criança é igual à outra. Encontro em Leite (2007, p. 49) razões para compreender sobre as diferentes infâncias:

Além de Expresso em verso e prosa, tintas, sons imagens, vem sendo pesquisado/pensado por muitos teóricos que certamente contribuem para a compreensão da criança como sujeito histórico, cultural e social que transforma e se transforma ao longo dos tempos; que se apropria criticamente de cultura e é também produtora de cultura.

O segundo bolsista respondeu que: "Ser criança é brincar, imaginar ser um super herói, nos dias de hoje a infância, vem trazendo conceitos diferentes de algum tempo atrás, pois a infância trazia a inocência de uma criança".

A resposta da segunda bolsista fica confusa, pois primeiro define criança e após compara a infância atual com a de tempos atrás, provavelmente a que ele viveu que em sua opinião trazia uma inocência que hoje parece não ter, fica nesta resposta evidente uma distorção e mistura de conceitos idealizados.

Na resposta da segunda pergunta o grupo A e B contribuem com os seguintes apontamentos:

Com relação ao primeiro bolsista, o mesmo respondeu (em 2012): “Ser criança é viver intensamente, sem malícia com a vida com as coisas do cotidiano. É brincar, criar, inventar, imaginar e assim fazer do dia a dia uma enorme brincadeira". Quando retomada a pergunta no questionário aplicado recentemente (2013), ele respondeu: 
É imaginar, brincar, ser limpo nos pensamentos, livre no corpo. É questionar o mundo e ser tocado pelas respostas. Lembro das aulas onde ensaiamos o canto do boi, a empolgação em conhecer as músicas, e lembro também do quanto foi mágico ver as crianças brincando com os bichos, e assim vivenciando um momento de descoberta.

Na primeira resposta o bolsista descreve um conceito de criança idealizado, sendo que remete a esta categoria somente a brincar e viver intensamente, quando a questão é retomada a fala ainda persiste, a criança com pensamentos ingênuos e muita liberdade, porém menciona as aulas de arte e a participação das crianças em uma das atividades propostas pelo Pibid que foi a restauração do Boi de Mamão como um momento no qual chamou a sua atenção para a manifestação e entusiasmo das crianças, comungo com o dizer de Pilloto $(2007$, p. 26) quando afirma que "[...] as crianças se desvelam e revelam-se por meio das manifestações expressivas. Materializam em formas, movimentos, sons os repertórios que vão se apropriando de um universo de histórias, situações e percepções".

Sendo assim, a expressão revelou o entusiasmo e o modo singular como cada criança se expressou quando foi permitido brincar com os personagens do Boi de mamão.

O quarto bolsista (grupo B) respondeu que: "A infância trazia momentos de lembranças, com brincadeiras sem responsabilidade, nos dias de hoje a infância traz momentos que muitos não querem lembrar, como a violência, a responsabilidade de trabalhar não existe no olhar de uma criança a inocência que deveria ter".

Nesta resposta há uma comparação de uma infância provavelmente a sua, no qual ficou marcada na lembrança, ao mesmo tempo, em que coloca a infância como passível de qualquer tipo de acontecimento até os mais negativos, ainda perpetua aquele ideal de ingenuidade no qual ele acredita que uma criança deveria ter.

Respondendo a terceira pergunta o grupo A e B os bolsistas trazem as seguintes respostas:

O primeiro bolsista (grupo A) respondeu que: "O trabalho do Pibid é importante, pois além de trabalharmos a arte em sala de aula, contribuindo positivamente para as aulas, nós fazemos isso pensando sempre no lúdico, na brincadeira, no resgate do comportamento de criança". O bolsista entende a importância dos trabalhos realizados em sala de aula juntamente com o professor de arte na escola.

O segundo bolsista (grupo B) respondeu que: "O Pibid desenvolve o projeto de iniciação à docência visando reconhecer a criança e suas diversas fases e em diferentes culturas". A fala do segundo bolsista é relevante uma vez que seus dizeres fizeram parte de leituras e discussões para a elaboração das atividades propostas.

A pesquisa contemplou outras falas que analisadas foram pontuando um parecer que auxilia direta ou indiretamente na resposta ao problema inicial. As considerações finais foram traçadas a partir do que foi possível perceber no desenrolar desse desafio.

\section{CONSIDERAÇÕES FINAIS}

Após a realização da análise das escritas dos bolsistas foi possível constatar algumas considerações sendo que por fim, mas não por último, a pesquisa não alcança uma resposta concreta e sua problemática não se esgota, mas propõe reflexões acerca do tema, no qual se torna relevante no desenvolvimento da prática educacional nas aulas de arte com crianças.

As questões analisadas, referente ao conceito de criança, do grupo A quando a pergunta foi realizada a primeira vez em 2012 pela coordenadora, havia uma confusão entre o conceito criança e infância uma vez que não desvinculavam uma da outra, sendo que na segunda resposta alguns conseguiram já compreender melhor as questões que permeiam os conceitos. Sobre infância na primeira vez que foram entrevistados relatavam uma visão idealizada, muitos deles se reportaram a sua infância como um modelo, no qual ao olharem para as que se configuram nos dias atuais, analisam os meios de comunicação e o mundo digital como influências negativas, sendo que este acaba impedindo a criança de viver a infância. As respostas foram escritas de acordo com o conhecimento empírico de cada bolsista. Quando responderam pela segunda vez traziam falas mais embasadas, alguns se reportaram a autores e entenderam a infância como uma construção social, porém em algumas respostas ainda ficou confuso o conceito de criança não se diferindo de infância. 
O grupo B dos bolsistas que entraram no decorrer do programa participaram de várias atividades, leituras e escritas sobre o tema, alguns demonstraram uma maior compreensão e outros ainda estavam confusos, lembrando, porém que o grupo é composto por bolsistas de diversas fases do curso de Artes Visuais, sendo que somente alguns haviam estudado as disciplinas de metodologias no qual trazem muitos conhecimentos, sobre o tema.

Na segunda questão quando todos os bolsistas responderam sobre o conceito de infância nos dias atuais, ficou evidente em suas escritas às lembranças que trazem da sua infância como momentos significativos, novamente falam em perda da infância, atribuindo negativa a disseminação da tecnologia, sendo algo que impede a criança de ter infância, porém a dinâmica da sociedade se modifica constantemente assim como o mundo e as questões que permeiam a família, a escola e a comunicação, desta forma, um modelo de infância ou uma comparação não cabe quando se entende os diferentes tipos de crianças, diferentes meios sociais e diversos modelos familiares.

Na terceira questão os bolsistas analisam as atividades realizadas no Pibid e sua influência quanto à concepção de infância, a maioria deles afirmou que a participação no programa foi muito importante e estar inserido no ambiente escolar antes mesmo da formação é uma oportunidade de conhecer o futuro ambiente de trabalho e seus desafios. Estar em contato com as crianças conhecendo esta categoria em seus aspectos e individualidades, o conhecimento sobre este tema contribuiu para a ampliação do repertório de experiências e vivências, uma vez que o programa elabora suas propostas de atividades dinâmicas estreitando cada vez mais a relação das crianças com a arte, pensando na criança atuante que se manifesta com autonomia, sendo assim, as aulas de arte contaram com sua participação.

A partir da ampliação de saberes através de filmes, leituras, escritas, discussões, elaboração de planejamentos, participação das atividades propostas pelo programa e o próprio contato com as crianças, acabou sendo modificada e melhor compreendida a visão dos bolsistas sobre criança e infância, sendo que este dizer se torna importante na construção das aulas de arte.

O professor de arte desempenhará bem seu papel, na medida em que, partindo daquilo que a criança já sabe (o conhecimento que ela traz de seu cotidiano, suas ideias a respeito dos objetos, fatos e fenômenos, suas "teorias" acerca do que observa o mundo), ele for capaz de ampliar e desafiar a construção de novos conhecimentos. 0 importante não é saber em qual idade se deve começar o ensino, mas em se conhecer o que a criança já sabe e dar continuidade ao processo, não desprezando seus conhecimentos adquiridos desde pequenos através de informações variadas, como as veiculadas em letreiros, revistas, comerciais de televisão, jornais, cartazes, livros e outros meios. 0 papel essencial do professor consiste em ser o mediador, o instrumento de união entre acriança e o objeto de estudo. É através dele que se dá a construção do conhecimento.

\section{REFERÊNCIAS}

[1] ARIÈS, Philippe. História social da criança e da família. 2.ed. Rio de Janeiro: Zahar, 1981.

[2] BRASIL. Constituição (1988). Constituição da República Federativa do Brasil. Brasília, DF: Senado Federal, 1988. Disponível em: <http://www.planalto.gov.br/ccivil_03/constituicao/constituicao>. Acesso em: 21 out. 2013.

[3] ___ Lei n. 8.069, de 13 de julho de 1990. Dispõe sobre o Estatuto da Criança e do Adolescente e dá outras providências. Diário Oficial da União, Brasília, DF, 16 jul. 1990a. Disponível em: <http://www.planalto.gov.br/ccivil_03/leis/18069.htm>. Acesso em: 21 de outubro de 2013.

[4] _. Decreto n. 99.710, de 21 de novembro de 1990. Promulga a Convenção sobre os Direitos da Criança. Diário Oficial da União, Brasília, DF, 22 nov. 1990b. Disponível em: <http://www.planalto.gov.br/ccivil_03/decreto/1990-1994/D99710.htm>. Acesso em: 21 out. 2013.

[5] __ Lei n. 9.394, de 20 de dezembro de 1996. Estabelece as diretrizes e bases da educação nacional. Diário Oficial da União, Brasília, DF, 23 dez. 1996. Disponível em: <http://www.planalto.gov.br/ccivil_03/leis/19394.htm>. Acesso em: 21 out. 2013.

[6] __. Ministério da Educação. Parâmetros curriculares nacionais: arte. 3.ed. Brasília, DF: MEC, 1998a.

[7] _. Ministério da Educação. Referencial curricular nacional para a educação infantil. Brasília, DF: MEC, 1998b. v.3.

[8] _. Ministério da Educação. Diretrizes nacionais curriculares para a educação infantil. Brasília, DF: MEC, 2010.

[9] _. Ministério da Educação. Coordenação de Aperfeiçoamento de Pessoal de Nível Superior. Edital Pibid n. 11/2012. Disponível em: 
[10] <http://www.capes.gov.br/images/stories/download/bolsas/Edital_011_Pibid-2012.pdf>. Acesso em: 28 ago. 2012.

[11] COHN, Clarice. Antropologia da criança. Rio de Janeiro: Jorge Zahar, 2005.

[12] GANZER, Adriana Aparecida. Turbilhão de sentimentos e imaginações: as crianças vão ao museu, ou ao castelo... In: LEITE, Maria Isabel; OSTETTO, Luciana E. Museu, educação e cultura: encontros de crianças e professores de com arte. Campinas: Papirus, 2005.

[13] GIL, Antonio Carlos. Como elaborar projetos de pesquisa. 4.ed. São Paulo: Atlas, 2002.

[14] HALL, Stuart. A identidade cultural na pós-modernidade. Tradução de Tadeu da Silva e Guaracira Lopes Louro. 7.ed. Rio de Janeiro: [s.n.], 2002.

[15] KRAMER, Sônia. A Infância e sua singularidade. In: BRASIL. Ministério da Educação. Ensino fundamental de nove anos: orientações para a inclusão da criança de seis anos de idade. Brasília, DF: MEC, 2006.

[16] LEITE, Maria Isabel. Tudo para criança deve ser infantil.In: PILLOTO, Silvia Sell Duarte (Org.). Linguagens da arte na infância. Joinville: Univille, 2007.

[17] MARTINS, Miriam Celeste; PICOSQUE, Gisa; GUERRA, Maria Terezinha Telles. Didática do ensino de arte: a língua do mundo: poetizar, fruir e conhecer arte. São Paulo: [s.n.], 1998.

[18] PILLOTO, Silvia Sell Duarte (Org.). Linguagens da arte na infância. Joinville: Univille, 2007.

[19] PILlOTO, Silvia Sell Duarte; PEREIRA, Leda T. C.; ROPELATO, Carla C. da S. Uma educação pela infância: diálogo com o currículo do 1o ano do ensino fundamental. Joinville: Univille, 2009.

[20] UNIVERSIDADE DO EXTREMO SUL CATARINENSE (UNESC). Normas para elaboração e apresentação do TCC do curso de Artes Visuais - licenciatura. Criciúma, 2012a. Disponível em: <http://www.unesc.net/portal/resources/files/42/normas_tcc_licenciatura.pdf>. Acesso em :11 set. 2012.

[21] _ _. Pibid educação básica: a intertextualidade de formação docente inicial e continuada. Criciúma, 2012b. Disponível em: <http://www.unesc.net/portal/capa/index/391/7216>. Acesso em: 10 set. 2012.

[22] VASCONCELLOS, Marcya. A arte entra em cena na escola. In: SILVA, Ângela Carrancho da; ROBERTO, Frank Wilson (Org.). Escola com arte: multicaminhos para a transformação. Porto Alegre: Mediação, 2006.

[23] ZAMBONI, Silvio. A pesquisa em arte: um paralelo entre arte e ciência. Campinas: Autores Associados, 1998. 


\section{Capítulo 8}

\section{As tensões presentes na formação docente: Práticas de estágio como matizes da construção dos saberes dos professores}

\section{Janaina Boniatti Bolson}

Resumo: 0 presente trabalho busca verificar, por meio da intervenção e atuação no espaço de práticas de estágio, as tensões presentes na formação docente, bem como compreender a influência dessas práticas como matizes da construção dos saberes dos professores no contexto atual. Para tanto, metodologicamente, o trabalho pautou-se pela análise de relatórios de estágios (análise documental) das alunas do $4 \stackrel{0}{ }$ semestre no componente curricular Estágio supervisionado II: intervenções pedagógicas nos anos iniciais do ensino fundamental do Curso de Pedagogia Parfor - Plano Nacional de Formação de Professores da Educação Básica. Foram utilizados para o processo da pesquisa autores como: Libâneo, Gatti, Chevallard, entre outros. Nesse espaço, verificouse, por intermédio dos relatos presentes nesses relatórios, como as alunas do curso percebem a necessidade da compreensão do sentido da didática como fundamento de ensino (teoria e prática) na formação de professores. Ainda é importante ressaltar que se torna essencial essa perspectiva para que ocorra a valorização dos docentes na sua profissão. Conclui-se que investir em processos de formação sustentados na constante relação entre conteúdos e métodos é fundamental. Na sociedade, em geral, como também no que se refere à formação de professores, não há como recusar a realidade de contextos sociais e culturais que marcam a contemporaneidade. Locais estes permeados por contradições que envolvem a cultura universal e o conhecimento local. Entretanto, embora existam essas configurações no modo de vida dos indivíduos, temos que estar cientes de que esses não podem ser ou vir a ser elementos que venham a negligenciar ou obstaculizar o acesso ao conhecimento. Essa clareza de conceitos é imprescindível na elaboração e execução de programas de formação de profissionais do Curso de Pedagogia, bem como dos demais cursos de licenciatura.

Palavras-chave: Didática. Formação de professores. Práticas de estágio. 


\section{INTRODUÇÃO}

A afirmativa de Simon Schwartzmann: "A qualidade de um sistema de educação não pode ser melhor que a qualidade de seus professores"(2011), proferida em um encontro de professores na cidade de Caxias do Sul, foi uma das nuances (entre outras tantas) responsáveis para a realização e relato da presente pesquisa. (GRIFO DO AUTOR). Ao ouvi- lo afirmar que os fatores que fazem uma boa educação não se referem, em um primeiro momento, ao que se investe financeiramente; ao formato da instituição (privada ou pública), ao número de alunos em sala de aula; às tecnologias usadas ou ao currículo adotado, e sim, dizem respeito à qualidade do professor e, como consequência disto, seu processo de formação; pude perceber que há futuro para este ofício se houver um resgate da profissão docente. Estes fatores reiteram a convicção de que a chave para uma educação eficaz e eficiente dá-se na qualidade da formação docente.

Partindo dessas ideias iniciais, é importante dizer que o cotidiano das escolas vem agregando aos docentes um crescente processo de afastamento de políticas e práticas de formação docente, uma vez que muitos professores vêm exercendo sua docência de modo individualista e pouco cooperativo, o que também gera uma defasagem nos processos formativos. Existem aspectos da formação inicial que contribuem para que ela seja um lócus privilegiado no desenvolvimento integrado de saberes e formas de atuar, de inserção na profissão e de desenvolvimento de uma identidade profissional. Sendo assim, acredita-se em um processo coletivo de formação, em que está presente uma multiplicidade de experiências profissionais. Contudo, é necessário que ela se torne o espaço também para a experiência, para a insegurança, para os anseios profissionais e as ansiedades em relação à prática docente trazidos pelo cotidiano da profissão. Pensar a formação inicial de professores implica perceber qual qualidade do ensino perpassa, especificamente, por uma formação adequada, ou seja, compreender que teoria e prática são processos indissociáveis.

A atual conjuntura aponta para o fato de que temos que rever a formação docente, já que algumas situações atende somente às necessidades do contexto econômico. Valorizar a experiência do professor é de especial importância; porém, deixando claro que suas concepções são voláteis e sempre passíveis de novas problematizações na busca de ideias e soluções para aquilo que se apresenta no cotidiano escolar e em sua profissão.

Na profissão docente, é essencial considerar a importância da criatividade na solução de cada nova situação vivenciada. Portanto, atuar na profissão considerando que há respostas previsíveis a todo tempo para as demandas impostas é algo, no mínimo, a se desconsiderar. Sabemos que há uma complexidade das práticas profissionais no trabalho docente, o qual enfrenta situações ambíguas que, por essa natureza, não se resolvem com as transposições de regras de decisão e modelos. Entretanto, algumas características são indispensáveis à profissão docente, dentre elas: a imprevisibilidade, a singularidade, a incerteza, a novidade, o dilema, o conflito e a instabilidade que nos levam a um necessário enfrentamento da racionalidade técnica.

No intuito do resgate ou implantação de práticas sugeridas como mais cooperativas para o exercício da docência, há, sem dúvida, a necessidade de uma reconfiguração da profissão docente que prevê uma espécie de novo associativismo docente, em que a ação coletiva do poder deste profissional não resida apenas em uma delegação de competências por parte do Estado.

Estes apontamentos feitos anteriormente vêm ao encontro do que pretendo apresentar na escrita do presente artigo. A pesquisa foi realizada em um Curso de Formação Continuada de Professores - o Parfor (Plano Nacional de Formação de Professores da Educação Básica) - Curso de Pedagogia com alunas do 4o semestre no componente curricular Estágio supervisionado II: intervenções pedagógicas nos anos iniciais do ensino fundamental desenvolvido no $2^{\circ}$ semestre do ano de 2012, no Instituto Federal do Rio Grande do Sul - Campus Bento Gonçalves.

O estágio apresentou-se sob a seguinte configuração durante o semestre:

- dez aulas presenciais que consistiram na fundamentação teórica da área de conhecimento da Educação nos Anos Iniciais; orientações e organização dos campos de estágio; prática no campo de estágio escolhido e avaliação e autoavaliação da prática exercida;

- duas aulas à distância para observações do campo de estágio; elaboração de relatório da referida observação e de pré-planejamento de atividades/ações para a prática no campo escolhido.

No transcorrer das aulas, os textos selecionados, para estudo, foram evidenciando a necessidade de esclarecimento e de discussões sobre o tema do exercício docente nos anos iniciais e a constante complexidade que vem sendo agregada ao papel docente no decorrer dos últimos anos. Essa afirmativa é producente nesse contexto uma vez que muitas das alunas desse curso de formação (Parfor) já atuam na 
docência em escolas públicas municipais e/ou estaduais (critério necessário para serem integrantes desse curso de formação). Eis, aqui, o foco da pesquisa desenvolvida: verificar por meio da intervenção e atuação, nesse espaço, quais as tensões presentes na formação docente, como também buscar a compreensão da influência das práticas de estágio como matizes da construção dos saberes dos professores no contexto atual.

A metodologia utilizada para o desenvolvimento da pesquisa foi desenvolvida em uma abordagem qualitativa por meio da análise de relatório de estágio das alunas do Curso de Pedagogia Parfor - Plano Nacional de Formação de Professores da Educação Básica - IFRS - Bento Gonçalves, na qual exerço docência. Os sujeitos envolvidos no processo investigativo constituíram um universo de 15 alunas, em que destaco, no decorrer da escrita, algumas das análises mais importantes, com vistas a uma condição mais significativa de compreensão do leitor. Para garantir a confiabilidade e a validação dos resultados de estudos qualitativos, Bradley (1993, p.436) sugere:

[...]o uso de quatro critérios para os atenuar,a saber: conferir a credibilidade do material utilizado, zelar pela fidelidade no processo de transcrição que antecede a análise, considerar os elementos que compõem o contexto e assegurar a possibilidade de confirmar posteriormente os dados pesquisados.

A pesquisa, com o uso de documentos, potencializa uma riqueza de informações que deles podemos extrair, já que possibilita ampliar o entendimento de objetos cuja compreensão necessita de contextualização histórica e sociocultural. Sendo assim, participaram da análise dos relatórios o grupo de alunas do programa Parfor do $4^{\circ}$ semestre. Lembrando que, a análise documental favorece a observação do processo de maturação de indivíduos, grupos, como também conceitos, conhecimentos, comportamentos, mentalidades, práticas, entre outros tantos aspectos a serem explorados pelo pesquisador (CELLARD, 2008). 0 referido autor afirma a existência de cinco dimensões presentes na utilização do método de análise documental, sendo estes: o conhecimento do contexto histórico, político e social de produção das informações (as quais favorecem sobremaneira ao pesquisador a compreensão e interpretação do conteúdo do documento); o conhecimento prévio do autor das informações, para apresentar como tal o entendimento da identidade, das razões e seus interesses que o levaram a escrever; a autenticidade e confiabilidade do texto, ou seja, sua procedência; a natureza do texto, verificar o suporte em que está escrito (contexto); e, por fim, os conceitos- chave e a lógica interna do texto, isto é, estar atento aos conceitos-chave presentes em um texto e avaliar sua importância e seu sentido, segundo o contexto preciso em que eles são empregados. Ao concluir, afirma ser útil examinar a lógica interna, o esquema ou o plano do texto. Eis o desafio presente para o processo investigativo no qual estou inserida.

\section{A DIDÁTICA NO CAMPO DA FORMAÇÃO DE PROFESSORES}

Quando estudamos o campo da formação de professores e, em especial, as práticas de estágio presentes nos cursos de formação, uma das vertentes a serem discutidas recaem sobre o lugar da didática, das didáticas disciplinares e das metodologias de ensino utilizadas nos cursos de formação de professores. Segundo Gatti e Nunes (2009), Libâneo $(2011,2013)$, entre outros pesquisadores da área, predomina, nos cursos superiores, a presença da didática instrumental aprisionada a aspectos prescritivos e pragmáticos e a um entendimento de metodologia simplório que não alcança o conhecimento necessário e instigador para a compreensão do desenvolvimento do processo ensino-aprendizagem. Nessa direção, Libâneo (2013, p.157) afirma que: "A separação entre conteúdo e método de ciência, entre conteúdos e metodologia de ensino, talvez seja a mais importante lacuna tanto nos estudos teóricos quanto nos formatos curriculares de formação de professores".

Enfim, observa-se que há a constituição de uma fragmentação entre o conhecimento do conteúdo (conhecimento disciplinar) e o conhecimento pedagógico do conteúdo (didática e didáticas disciplinares); aspectos os quais sabemos que são indissociáveis na formação docente. Aqui, aparece outra situação que merece destaque na constituição do docente em seus processos de formação: o fato de que a didática dos professores e as metodologias de ensino precisam compreender aprofundadamente a complexidade do processo ensino- aprendizagem e todas as implicações presentes na relação do aluno com um objeto de conhecimento. Em outras palavras, ao docente é requerida a competência em propor tarefas com base em conteúdos que possibilitem a atividade mental dos alunos para a operacionalização de conceitos.

A partir desses pressupostos, apontados para o ensino da didática nos cursos de formação de professores, não há como negar que pensamos a educação como uma prática social, materializada em ações efetivas, 
voltadas para a formação e desenvolvimento dos seres humanos, envoltas em condições culturais e sociais, com vistas à expressão das aprendizagens efetivamente realizadas. Há que se ressaltar nessa relação de ensino-aprendizagem: as aprendizagens efetuadas dão-se no âmbito docente e discente. E, sendo assim, podemos visualizar as práticas de estágios e a prática docente no exercício da profissão como processos constantes de aprendizado na formação docente. Na esteira das afirmativas acima, torna-se fundamental tratarmos de outro termo/ conceito reiteradamente mencionado ao referirmo-nos à formação de professores, o fato destes (os docentes) serem os mediadores do conhecimento. A partir disso, faz-se importante mencionar o que Libâneo (2012) denomina de mediação didática, a qual supõe que, para que ocorra, é necessário existirem os conteúdos e os métodos inerentes a esses conteúdos, que são referências, ponto de partida para a construção do processo de ensino-aprendizagem. Dito de outra forma:

[...] não há conteúdos fora dos métodos que levaram à constituição de um objeto de conhecimento. Também não há didática fora da relação do aluno com o conteúdo (fora da transformação das relações do aluno com o conteúdo), como não há didática separada das práticas socioculturais e institucionais em que os alunos estão envolvidos (LIBÂNEO, 2013, p.162).

Por fim, contextualizar a didática nas dimensões dos sujeitos envolvidos no processo de ensino aprendizagem, parece-me crucial para que possamos perceber e aprofundar os estudos sobre formação docente. E, nesse estudo em especial, discutir em bases teórico- metodológicas das práticas de estágio como matizes da construção dos saberes dos professores no contexto atual. A didática, portanto, articula simultaneamente a lógica dos saberes a ensinar, a lógica dos modos de aprender, os contextos socioculturais e institucionais que envolvem a aprendizagem.

\section{DESCOBERTAS DA PESQUISA}

Por meio da abordagem qualitativa utilizada para investigação, é importante ressaltar que as análises realizadas foram pertinentes ao objeto em questão e articuladas para a possibilidade de construir categorizações significativas sobre a problemática desenvolvida.

Para tanto, seguem algumas falas integrantes dos relatórios de estágio em Anos Iniciais que proporcionaram a análise de dados, conforme a metodologia já descrita anteriormente. Segundo o relato de uma das alunas, A12: "O estágio docente sempre faz parte das práticas dos cursos de formação para professores, sendo assim, é na prática que se aprende e não só na teoria, visto que, juntas elas se completam. 0 estágio é o momento em que se fica próximo à realidade escolar, na qual a estagiária vai poder praticar as teorias que aprendeu ao longo do curso." Por intermédio dessa fala, fica clara a necessidade da compreensão da didática como processo instrucional que orienta e assegura a unidade entre o aprender e o ensinar na relação com um saber, ou seja, sua especificidade epistemológica (LIBÂNEO, 2013). Como o próprio autor afirma (p.152): “[...] a didática assegura a unidade entre o ensino e a aprendizagem, articulando dialeticamente condicionantes socioculturais da atividade de ensino e processos internos da atividade de aprendizagem."

A fala de A2 apresenta um caráter instigante: "O estágio serve para que o aluno se localize e reconheça o espaço escolar e para que o professor forme sua identidade docente com as experiências adquiridas ao longo do curso, a partir da aproximação com os alunos." Nesse relato, surge um aspecto hoje muito em voga nos cursos de formação, inclusive nas políticas públicas sobre estes; a inserção do professor em formação no estágio desde a metade do curso, que segundo Fernandes (2008, p.239): “[...] rompe com uma visão de que a teoria antecede à prática e esta, a prática, reduz-se à aplicação de teorias, compreensão de conhecimento e de ciência arraigada em nossos currículos e em nossas concepções."

Ainda referente às práticas de estágios, há outras falas significativas, como o relato de A3: "É nessa trajetória que os saberes são colocados na prática, fazendo relação, estabelecendo o aprender para a futura profissão. É um desafio necessário do ensinar/aprender que o Curso proporciona. O professor em estágio exerce a ação docente ampliando as possibilidades de contribuir para o processo de formação imprescindível para o desenvolvimento profissional articulando teoria e prática. É nesta articulação que se constrói a identidade do professor." É interessante observar como o binômio - teoria e prática - surge, e junto a ele, a menção ao termo articulação (GRIFO DO AUTOR). Nesse sentido, são importantes os argumentos de Charlot (2000, p.63) com referência ao cuidado epistemológico e ontológico para trabalhar a prática e os saberes que dela fazem parte: "A prática não é cega, ela tem ferramentas e organiza seu mundo; ela supõe e produz o aprender. Mas esse aprender, que é o domínio de uma situação, não é da 
mesma natureza, nem em seu processo, nem em seu produto, que é o saber enunciável como saber objeto".

A fala de A3 remete-nos a conceitos e ideias que mais recentemente vêm sendo incorporadas ao âmbito da formação de professores: "Também é necessário que nos preocupemos com a metodologia, para que o aluno se aproprie do conhecimento e não apenas o memorize sem lhe fazer sentido. Muito mais do que assistir às aulas, podemos "fazer aulas", havendo assim troca de ideias. 0 professor atuando com seus alunos sobre o objeto de estudo que está sendo visto." Embora saibamos que, atualmente, diferentemente do passado, estejamos na busca da instalação de um modelo profissionalizante ou profissional voltado para a prática, em oposição ao modelo acadêmico tradicional (que visa, sobretudo, à produção de conhecimento) vigente nas instituições de ensino superior (BORGES, 2008), a fala de A3 remete-nos, sobremaneira, aos fatores relacionais inerentes ao processo de ensino- aprendizagem, configuradas nesse relato na expressão "fazer aulas"; a partir de um objeto de estudo apropriado por intermédio de uma ação pedagógica que prescinde de um método que proporcione o conhecimento.

O relato de A5 trata do conceito de educação e, por conseguinte, a atuação do docente. Segundo a aluna: “A educação precisa ainda perder muito conceitos estipulados pelo senso comum, pois só assim, teremos a possibilidade de oferecer um ensino visando à qualidade do aprendizado que o aluno adquire. Ensinar é muito mais que só passar conteúdos, pensando na futura profissão, ou no mercado de trabalho. Ensinar é ir além. Envolvem conhecimentos, informações, valores, crenças, ciência, arte, tecnologia, filosofia, direito, costumes; tudo de que o ser humano precisa para constituir sua cultura." Ao analisar a presente afirmativa, o que me move, inicialmente, é o que Schneuwly (1995) e Chevallard (1985) denominam de transposição didática (GRIFO DO AUTOR) que nada mais é do que a retirada de um objeto que funciona dentro de um contexto, exterior ao sistema de ensino-aprendizagem, para torná- lo objeto de ensino. Dito de outra forma:

"[...] a cada momento, quando o objeto de saber constitui-se em objeto de ensino e, em seguida, em objeto ensinado, o conteúdo é trabalhado por adaptações sucessivas, ou seja, o trabalho de transposição é um trabalho que continua após a introdução didática do objeto de saber" (BARROSMENDES, 2008, p.68).

Sendo assim, ao afirmar que a educação precisa ser pautada por conhecimentos técnico-científicos, ao invés de estar sendo (em muitos momentos) gerenciada por mecanismos presentes no senso comum (GRIFO DO AUTOR), é visível atentarmos para o fato de que essa necessidade é apontada pelas docentes em formação e atuantes na profissão (sujeitos dessa pesquisa), uma vez que os saberes são transformados para serem ensinados. Concomitante a isso, necessitam ser didatizados, ou seja, apresentados como saberes a serem ensinados e aprendidos.

Foram aqui destacadas falas que denotam a presença de concepções referentes ao ensino-aprendizagem no imaginário dos docentes que vão ao encontro de conceitos essenciais do campo pedagógico da formação de professores. São eles: didática, ensinar, aprender, mediação, entre outros abordados e mencionados. Sabemos que o ensino acontece no contexto social, e fica claro que as atividades de uma disciplina (nesse caso no componente curricular Estágio supervisionado II: intervenções pedagógicas nos anos iniciais do ensino fundamental) orientadas para a formação de processos mentais dos alunos, por meio dos conteúdos científicos, tornam-se interessantes se articuladas com as formas de conhecimento cotidiano dos alunos. Enfim, as práticas pedagógico-didáticas, estando integradas às práticas socioculturais e institucionais, fomentam os processos de ensino-aprendizagem (LIBÂNEO, 2013).

Percebe-se que, para assumir-se como professor é requisitada a clareza de muitos aspectos constituintes da função a ser realizada. É preciso, sim, ter metas e objetivos, saber sobre o que se vai ensinar, mas não se pode perder de vista, um segundo sequer, para quem se está ensinando e é disso que decorre o como realizar. 0 processo de ensino-aprendizagem está imerso em diversas facetas, ou seja, das condições do aluno, sua capacidade de aprendizagem, as estratégias de ensino, o contexto cultural e histórico em que se situam todas essas características. Conjugar essas variáveis exige compromisso e responsabilidade com o aluno, o que permite avançar nos processos de ensino-aprendizagem.

Daí, o aspecto relatado pelas alunas reiterando que não há como formar professores sustentados somente numa perspectiva de um desenvolvimento profissional de caráter meramente técnico ou instrumental. É preciso promover também a sensibilidade política e ética; condição para que se perceba que o mundo docente ultrapassa, em muito, as dimensões dos muros da escola. Conhecer de perto o macro-contexto em que se atua, significa perceber que as iniquidades e as disfunções presentes na escola fazem parte da sociedade mais ampla e são dela apenas manifestações. Conhecer as vicissitudes da escola - e empreender 
nela as mudanças necessárias - pode levar os professores a combater também os problemas da sociedade, sua injusta distribuição de riquezas e de poder.

\section{CONSIDERAÇÕES FINAIS}

Um dos aspectos importantes a serem destacados para a reflexão referida à formação e ao exercício docente é o que Nóvoa (2003) aponta, de maneira significativa, como a necessidade de conseguirmos estabelecer um novo contrato pedagógico com os alunos o qual exclua a possibilidade de continuarmos a alimentar as ilusões com urgência, sendo uma delas o fato de que a escola pode algumas coisas, porém, não tudo. E, é esta consciência que deve ser desenvolvida nas famílias, dos limites e das possibilidades. Neste sentido, o docente, enquanto agente habilitado a ensinar, deve constantemente apontar, no seu cotidiano de trabalho, estas situações. Nóvoa $(2003$, p.5) assim discorre:

o pior de tudo são as ilusões. Elas provocam a decepção e, a prazo, a demissão. Os educadores deixam-se tentar, muitas vezes, por discursos miríficos de uma escola que iria transformar o mundo ou salvar as pessoas. Não vai. Temos de ter uma consciência mais terrena das nossas possibilidades de intervenção. E, com base nesta consciência, consolidar novos laços e compromissos pedagógicos.

Nessa dimensão, e com base na análise de dados da referida pesquisa, a formação do educador - inicial e, por conseguinte, continuada - necessita apresentar-se, a partir de múltiplas configurações, que não estejam reduzidas à reprodução das informações, à memorização de dados, passando a promover as condições necessárias para superar uma visão sincrética - percepção ingênua da realidade, fundamentada no senso comum - para alcançar uma visão sintética - concepção clara e unificada dessa mesma realidade, mas, fundamentada no senso crítico - através da mediação decorrente de análise baseada no saber elaborado.

Para tanto, na sociedade, em geral, e também com referência à formação de professores, não há como recusar a realidade dos contextos sociais e culturais que marcam a contemporaneidade; locais estes permeados por contradições que envolvem a cultura universal e o conhecimento local. Entretanto, embora existam essas configurações no modo de vida dos indivíduos, temos que estar cientes de que esses não podem ser ou vir a ser elementos que venham a negligenciar ou obstaculizar o acesso ao conhecimento, e, por conseguinte, do processo ensino-aprendizagem.

Ao refletirmos sobre a formação inicial dos profissionais da educação, temos que considerar as profundas transformações sociais, culturais, tecnológicas que influenciam nossa maneira de conceber e nos relacionarmos com o mundo e conosco. Percebe-se que tais mudanças atravessam a universidade, e mobilizam-nos a atuar em um contexto multifacetado. A educação, fruto da realidade complexa da qual somos parte, deve perpassar pelas expectativas de um sujeito que deve circular em contornos mutáveis e incertos, mediados por novas tecnologias e em constante produção e renovação do conhecimento.

Para tanto, é pertinente que nos questionemos para que possamos retomar um processo de refazer nossas identidades como docentes. E, de certo modo, reduzir a profissão docente das ambiguidades, que estão entranhadas no dia a dia da docência. Ou seja, se não investirmos nessas ações, urgentemente, cada vez mais outras instâncias (Estado, Universidades, etc.) ocuparão e, já estão ocupando, de certa forma, o território deixado livre por nós mesmos, do qual este será palco de um processo cada vez mais intenso de desprofissionalização e desqualificação docente. 0 sentido da didática, como fundamento de ensino (teoria e prática) na formação de professores, é essencial para que ocorra a valorização dos docentes na sua profissão, como bem afirma Libâneo (2013,p.161): “A inseparabilidade [...] entre didática e didáticas disciplinares parece ser a questão crucial dos formatos curriculares de formação de professores." 0 autor (LIBÂNEO, 2013) prossegue afirmando que há a necessidade de uma unidade do processo formativo, a qual:

[...] implica reconhecer que a formação inicial e continuada de professores precisa estabelecer relações teóricas e práticas mais sólidas entre a didática e a epistemologia das ciências, a fim de romper com a separação entre conhecimentos disciplinares e conhecimentos pedagógico-didáticos (LIBÂNEO, 2013, p.161). 
Conclui-se que investir em processos de formação sustentados na constante relação entre conteúdos e métodos é fundamental. Essa clareza é essencial na elaboração de programas de formação de profissionais do Curso de Pedagogia, bem como dos demais cursos de licenciatura.

\section{REFERÊNCIAS}

[1] BARROS-MENDES, A. das N. N. A língua portuguesa e seu ensino hoje: desafios em didatizá-la. In: TRAVERSINI, C.; EGGERT, E.; PERES, E.;BONIN, Iara. (Org.).

[2] Trajetórias e processos de ensinar e aprender: práticas e didáticas. 1. ed. Porto Alegre: EDIPUCRS, 2008, p.59-83.

[3] BORGES, C.. A formação docente em Educação Física em Quebec: saberes espaços, culturas e agentes. In: TRAVERSINI, C.; EGGERT, E.; PERES, E..;BONIN, I. (Org.). Trajetórias e processos de ensinar e aprender: práticas e didáticas. 1. ed. Porto Alegre: EDIPUCRS, 2008, p.147-174.

[4] BRADLEY, J. Methodological issues and practices in qualitative research. Library Quarterly, v. 63, n. 4, Oct. 1993, p. 431-449.

[5] CELLARD, A. A análise documental. In: POUPART, J. et al. A pesquisa qualitativa: enfoques epistemológicos e metodológicos. 1. ed. Petrópolis: Vozes, 2008, p.29-42.

[6] CHARLOT, B. Da relação com o saber: elementos para uma teoria. Porto Alegre: Artmed Editora, 2000.

[7] CHEVALLARD, Y. La transposição didactique, du savoir savant au savoir enseigné. Suvie de Un exemple de La trasposition didactique -de Ivey Chavallard et Marie- Albert Johsua - Paris: La pensée Sauvage Editions, 1985.

[8] FERNANDES, C. M. B.. O espaço-tempo do estágio nos movimentos do curso: interrogantes, desafios e construção de territorialidades. In: TRAVERSINI, C.; EGGERT, E.; PERES, E.;BONIN, I. (Orgs.). Trajetórias e processos de ensinar e aprender: práticas e didáticas. 1. ed. Porto Alegre: EDIPUCRS, 2008, p.231-248.

[9] GATTI, B. A.; NUNES, M.M.R. (Orgs.) Formação de professores para o ensino fundamental: Estudo de currículos das licenciaturas em pedagogia, língua portuguesa, matemática e ciências biológicas. São Paulo: Fundação Carlos Chagas/DPE, 2009.

[10] LIBÂNEO, J. C. Didática como campo investigativo e disciplinar e seu lugar na formação de professores no Brasil. In: OLIVEIRA, M. R. N. S.;PACHECO, J. A. (Orgs.).Currículo, Didática e Formação de professores (Série Prática Pedagógica),1.ed. Campinas, São Paulo:Ed. Papirus, 2013, p. 131- 166.

[11] LIBÂNEO,J. C. Educação Escolar Políticas, Estrutura e Organização. São Paulo:Cortez, 10. ed. 2012.

[12] LIBÂNEO,J. C. Que destino os educadores darão à Pedagogia? In: PIMENTA, S. G. (Coord.)

[13] Pedagogia, ciência da educação ? 2. ed. São Paulo: Cortez, 2011, p. 107-134. NÓVOA, A. Dicionário de educadores portugueses. Porto:ASA, 2003.

[14] SCHNEUWLY, B. Comment faire de la didactique du français langue maternelle aujourd'hui? Transcrição remaiée d' une intervention orale faite le 26 juin 1995 à Bordeaux, à L'IUFM. - 1. ed. Paris,1995, Digitado- Circulação restrita. 


\section{Capítulo 9}

\section{Experiência de estágio curricular: Contribuição aos saberes e formação docente}

\section{Isabel de Carvalho Paiva \\ Rozilda Pereira Barbosa}

Resumo: 0 estágio é o laboratório do curso de Pedagogia, o contato mais próximo e real com a docência, espaço de correlacionar teorias e práticas educativas. 0 estudo em foco desenvolveu-se a partir das experiências obtidas no Estágio Curricular dos Anos Iniciais do Ensino Fundamental, sob a metodologia de observações, coparticipações e regência no processo didático-pedagógico, configurando-se como uma pesquisa de cunho qualitativo engendra análises sobre as contribuições do estágio para a formação docente mediante os desafios da sala de aula nos dias de hoje. Fundamenta-se nos estudos de Libâneo (2006), Pimenta (1997), Saviani (1991), Nóvoa (1992), Oliveira (1997), Wallon (1979) e Souza (2011), teorias que norteiam práticas pedagógicas de ressignificação à formação docente e acompanhamento ao desenvolvimento integral da criança. Concluise que o estágio permite a junção de técnicas e vivências que não se limitam a instrumentação, mas interação entre o fazer pedagógico e a indissociação entre teoria e prática.

Palavras-chave: Estágio Curricular. Prática Pedagógica. Formação Docente. 


\section{INTRODUCĈ̃O}

A formação docente é fator determinante na qualidade do ensino e o estágio curricular essencial à formação docente, o referido possibilita uma aproximação do formando com o seu futuro campo de trabalho, no qual a partir de um contexto prático, real, depara-se com os desafios da profissão, é levado a refletir e buscar estratégias que possibilitem os processos de ensino e de aprendizagem.

Considerando o acima exposto apresentamos no decorrer deste trabalho reflexões, saberes engendrados a partir da experiência de estágio curricular nos Anos Iniciais do Ensino Fundamental, realizado em uma instituição pública no município de Crateús-Ceará. Foram levados em consideração as observações do espaço pedagógico, a estrutura física da escola, atendimento da direção, a relação interpessoal do grupo gestor e educadores, a práticas dos planos de aula e o mais importante o fazer pedagógico mediante os novos desafios da sala de aula.

Durante o tempo em campo, verificou-se a importância que o estágio possui, possibilita um contato real das funções da docência e o funcionamento do sistema educacional, assim como permitiu enxergar os anos iniciais como campo de pesquisa para temas mais ligados a formação do pedagogo e sua saúde psicológica e física.

A pesquisa no estágio, como método de formação dos estagiários futuros professores, se traduz, de um lado, na mobilização de pesquisas que permitam a ampliação e análise dos contextos onde os estágios se realizam; por outro, e em especial, se traduz na possibilidade de os estagiários desenvolverem postura e habilidades de pesquisador a partir das situações de estágio, elaborando projetos que lhes permitam ao mesmo tempo compreender e problematizar as situações que observam. (PIMENTA; LIMA 2004, p. 46)

Em conformidade com as orientações da disciplina de Estágio, as atividades ocorreram seguindo uma organização, foram realizados estudos teóricos sobre as bases filosóficas e legislação do estágio curricular, procedimentos em sala de aula, encontros para planejamento das ações durante o estágio, observações na instituição, coparticipações e regências no processo pedagógico.

\section{DIALOGANDO COM OS TEÓRICOS DE ESTÁGIO E CONHECENDO O CAMPO DAS PRÁTICAS DE ENSINO.}

A junção de teoria e prática no percurso do estágio demostraram a articulação, sistematização da pedagogia, a interdisciplinaridade dos conhecimentos e como o profissional se constrói também em seu dia a dia. Para Pimenta (1997, p. 69) "Teoria e prática são indissociáveis. A prática [...] é o ponto de partida e de chegada. A consequência disso é que ninguém se tornará profissional apenas porque "sabe sobre" os problemas da profissão, por ter estudado algumas teorias a respeito".

Para Pimenta, o cerne da docência é o ensino-aprendizagem que envolve todos os aspectos educacional e sociais:

A essência da atividade (prática) do professor é o ensino-aprendizagem. Ou seja, é o conhecimento técnico prático de como garantir que a aprendizagem se realize como conseqüência da atividade de ensinar. Envolve, portanto, o conhecimento do objeto, o estabelecimento de finalidades e a intervenção no objeto para que a realidade (nãoaprendizagem) seja transformada, enquanto realidade social. Ou seja, a aprendizagem (ou não-aprendizagem) precisa ser compreendida enquanto determinada em uma realidade histórica-social. (PIMENTA, 1997. p.83)

No decorrer das observações do Estágio Curricular foram constatados que o ensino tradicional é optado por gestores e docentes com o argumento de que é o que causa resultados na disciplina e aprendizado do aluno. Segundo Saviani (1991. p.54) "Esse ensino tradicional que ainda predomina hoje nas escolas se constituiu após a revolução industrial e se implantou nos chamados sistemas nacionais de ensino, [...]". Na rigidez dos espaços escolares e a urgência de se transmitir conhecimentos nos dias de hoje, não se garante ao aluno o respeito ao seu tempo de aprendizado e desenvolvimento de habilidades essenciais para a vida, pois no ensino tradicional como afirma Libâneo (2006 p. 22), " [...] o aluno é educado para atingir, pelo próprio esforço, sua plena realização como pessoa". 
Com estrutura física consideravelmente apropriada, embora tenha reservas quanto a isso, a instituição observada se destaca por ter em seu exterior um amplo espaço e paisagem agradável, porém parece não ser visto sob o viés pedagógico, o que o torna inútil no dia a dia. No interior corredores estreitos, escuros, salas pequenas e superlotadas dificultam as atividades pedagógicas. No que se refere a acessibilidade, a escola ainda não atende aos requisitos necessários para melhor locomoção de pessoas com limitações físicas.

Conforme afirmam Barbosa e Horn (2007, p.73) "[...] o espaço físico é fundamental para o desenvolvimento das crianças, na medida em que ajuda a estruturar as funções motoras, sensoriais, simbólicas, lúdicas e relacionais". Nesse sentido pela limitação estrutural as ações pedagógicas tornam-se fragmentadas a um ensino focado na sala de aula onde o alunato se sujeita apenas ao conteúdo exposto.

A escola neste ano de 2019 aderiu o paradigma de tempo integral do 1o ao 5o ano do Ensino Fundamental, todavia a estrutura é limita para tal façanha, por não ter ainda realizado a licitação de alimentação referente ao almoço das crianças, estas devem ir em busca da refeição em seus lares e depois retornarem para as aulas no turno da tarde, este fato evidencia a fragilidade do modelo educativo, o que se torna penoso e injusto à infância, considerando que muitas dessas crianças vivem em situação de vulnerabilidade social, retornam para a escola sem a refeição principal e tem que aguardar o horário da merenda. 0 ensino em tempo integral que deveria garantir a criança as alimentações básicas e necessárias ao seu desenvolvimento físico e intelectual, inicia-se enviesado.

\section{A SALA DE AULA: CONSIDERAÇõES ACERCA DO PROCESSO DIDÁTICO- PEDAGÓGICO}

Em sala de aula foi possível perceber que o espaço não permite uma diversificação das atividades pedagógicas devido a sala ser pequena. Sem muito destaque de cores que atraia atenção das crianças, a decoração está limitada à cartazes com boas vindas, dia da semana, data e combinados, quadro do alfabeto e um adesivo da "princesa Sofia" não se relacionando ao contexto social e cultural no qual a escola está inserida. É importante destacar que a organização do espaço pedagógico influencia também na aprendizagem da criança e a imagem que tem de si, ainda ressaltamos que diz muito sobre o educador e a importância que aquele local desempenha para ele.

No primeiro dia de observação em sala acompanhando o trabalho pedagógico da professora Aurora 5 , houve aplicação de uma prova da Secretaria de Educação. 0 Diagnóstico Inicial - Português e Matemática serve como triagem e detecção das habilidades adquiridas ou deficiências no ensino. A referida atividade demandaria a organização da sala, instruções aos alunos, leitura das questões e acompanhamento para que não houvesse tumultuo e fosse garantida a participação dos alunos ativamente na prova. Como as crianças não foram preparadas para realização de provas, pois era a primeira vez delas, demanda tempo para entenderem e consequentemente por não saberem escrever e ler tudo é complexo para as crianças. Muitas solicitavam reexplicação, outras se desesperavam por não compreenderem as instruções da professora.

No que concerne a prática pedagógica, o observado confirma a predominância de traços da corrente tradicional. Para Libâneo (2006. p. 22) no modelo em discussão "Os conteúdos, os procedimentos didáticos, a relação professor-aluno não tem nenhuma relação com o cotidiano do aluno e muito menos com as realidades sociais. É a predominância da palavra do professor, das regras impostas, do cultivo exclusivamente intelectual".

A metodologia tradicional e rígida do educador não aproximava a criança do conteúdo repassado, criando um ambiente hostil, gostaria de pensar que tudo aquilo fosse situações circunstanciais, mas a reação da turma conota que é rotineiro. Ouvir frases do tipo "tenho até dezembro pra ensinar vocês a serem gente! ", e "não vou aceitar menino que não quer estudar! ", "você não aprende porque não quer, eu estou ensinando, porque não aprende? ", "mulher, a gente se mata aqui e menino não aprende", "vocês é que fazem a gente gritar?".

As frases de efeito intimidadores foram referidas em vários momentos de uma aula de 40 minutos. Em dados momentos eu mesma tive que engolir o choro por relembrar tantas vezes em que tive isso em sala de aula durante minha infância, quantas vezes fui instigada a duvidar de me

\footnotetext{
${ }^{5}$ Nome fictício para preservar a identidade da docente
} 
porque o professor não aceitava respostas erradas, por julgar como incivilidade todo argumento e locomoção em sala de aula, por julgar que não saber ler aquela palavra era sinal de "burrice"! (DIÁRIO DE CAMPO, 2019)

As observações fizeram surgir a inquietude pedagógica em notar deficiências na aprendizagem dos alunos, em 9 deles, para ser mais exata: não decodificação dos signos; raciocínio lento; não desenvolvimento da coordenação motora fina.

Ainda durante o período de observação percebeu-se que as inquietações das crianças resultam em constantes conflitos em sala de aula, alguns casos de incivilidades são preocupantes para o contexto escolar. Algumas crianças chegam à escola cheias de energia, outras cansadas, irritadas, sonolentas para acompanhar atentamente as aulas. Com tudo a aula seguiu como planejado, conteúdo de Geografia e atividade esportiva, ambos trabalharam com a identidade da criança, nome e o jeito de ser, foram trabalhados o nome e escrita, houve a roda de conversa com música na área externa da escola.

$\mathrm{Na}$ observação do trabalho da professora Flor ${ }^{6}$ notou-se a fragilidade das ações didáticas onde a ludicidade é pouco explorada como ferramenta pedagógica, o uso da referida unindo o conteúdo e jogos promoveria melhor assimilação e dinamismo em sala, por ser um ensino em tempo integral, a proposta lúdica faria o período menos desgastante para professor e aluno. Guillarme (1983, apud OLIVEIRA 1997, p. 22) " ressalta a importância das experiências motoras no processo de maturação e acredita que uma experiência pobre pode retardar essa maturação".

Diferente de Aurora, Flor tem uma linguagem de fácil compreensão pelas crianças, consegue acalmar e aconselhar com brandura no falar, dirige de forma respeitosa e mantém diálogo com os alunos. Aceitando sugestões e busca criar nos espaços da escola melhores experiências para os alunos sem se perder do seu plano de aula.

As observações foram decisivas na elaboração das possíveis atividades para as regências, assim como apuraram o olhar sobre a relação professor-aluno, a relação professor-gestores e a comunicação entre os colegas educadores que podem contribuir no melhor desenvolvimento da profissão de forma a ter em sala de aula a soma de tudo isso para práticas pedagógicas que contribuam no desenvolvimento integral da criança.

Durante a coparticipação com a professora Aurora, a sala foi organizada em 5 (cinco) filas para controle aos alunos, ou nas palavras da referida "querendo ou não o que funciona mesmo é o tradicional". Um aluno foi nomeado para ser o auxiliar da professora, tem a tarefa de buscar material, vigiar a sala e lhe é exigido um comportamento impecável para permanência na função.

O conteúdo de português foi focado na escrita do nome e leitura do alfabeto, com atividade do livro didático. A contribuição das estagiárias se deu no acompanhamento às crianças mais vulneráveis em sala, a maioria não sabe nem decodificar os signos, não compreendem os comandos e com visíveis receios quanto a expressar que não entendem o que é ensinado, no decorrer da aula há frequente inquietação das crianças, choro e irritação.

O espaço em sala de aula limita não apenas a movimentação, mas a própria construção das aulas e a interação do aluno com o conteúdo. Constatando que as crianças não entendem porque não compreendem o som e forma das letras, procurou-se na coparticipação do estágio ensinar por meio dos sons as vogais e consoantes, simultaneamente procurávamos assimilar figuras do próprio livro da criança.

Realizada a leitura do texto do livro, notou-se que as crianças ficam calmas quando se cria um ambiente calmo, leitura branda e acompanhamento individual. É claro que essas impressões estão sujeitas ao erro, pois as estagiárias são naquele momento a novidade em sala, de certo todas as suas ações terão um impacto nas crianças.

Na coparticipação ao trabalho da professora Flor, a rotina iniciou com um diálogo sobre o horário de almoço, oração, chamada indicando letra inicial do nome e do sobrenome. Leitura dos combinados e informes sobre a aula da tarde. Foi percebido um ambiente mais leve e com domínio de sala, as crianças evidentemente retornam cansadas e sonolentas. Algumas crianças não se alimentaram em seus lares ${ }^{7}$ e

\footnotetext{
${ }^{6}$ Nome fictício para preservar a identidade da docente

7 A escola em 2019 aderiu ao Ensino em tempo integral, porém a licitação referente ao almoço ainda corre em tramitação, nesse período as crianças vão almoçar as 11 h00min em seus lares e retornam as $13 \mathrm{~h} 00 \mathrm{~min}$.
} 
perguntam insistentemente sobre o horário do recreio (o lanche é distribuído simultaneamente ao intervalo).

Na aula de ciências, conduzimos as crianças até o laboratório, onde receberam do professor de ciências orientações sobre seres vivos abióticos e bióticos, o processo de decomposição de elementos que se renovam no ciclo da vida.

Das coparticipações foram notadas as deficiências em sala de aula, seus desafios quanto ao comportamento dos alunos, a valorização dos conhecimentos sobre psicologia da aprendizagem, currículo e psicomotricidade, essenciais para práticas pedagógicas de valorização ao profissional e alunato.

\section{EM SALA DE AULA É CHEGADA A HORA DA REGÊNCIA: É POSSÍVEL FAZER DIFERENTE?}

As regências ocorreram de 12 de março a 04 de abril de 2019 nos turnos tarde, com as disciplinas de História, Geografia, Reforço de matemática, artes e Atividade Esportiva. 0 processo de regência demandou além de conhecimentos da psicologia da aprendizagem, currículo e da psicomotricidade, tempo e recurso financeiro para produção de material de apoio pedagógico e lúdico para as crianças.

Para a regência considerou-se as aprendizagens construídas nas observações e coparticipações acerca dos alunos, assim procurou-se reajustar as ações didáticas levando em consideração a existência na turma de um aluno com laudo de hiperatividade emitido por psicólogo, outro com comportamento semelhante, porém sem laudo que confirme necessidade especifica, bem como 9 alunos que não possuíam bases para inserção no processo de alfabetização, devendo-se trabalhar a coordenação motora fina e grossa, introduzir eles ao grupo e buscar alternativas para desenvolver esperançosamente as habilidades básicas necessárias a alfabetização e letramento.

No primeiro dia de regência recebemos os alunos com diálogo aberto, repassamos a rotina com: data e dia da semana, requisitando a participação de 3 alunos para indicar e relatar um pouco do seu dia, repassamos os combinados e organizamos a sala de aula para que todos conseguissem visualizar o quadro e ter movimentação em sala.

\subsection{CONTEÚDOS DE MATEMÁTICA}

No conteúdo de matemática, trabalhamos os números de 11 a 20, a ordem e forma como juntamos os números. Para a explicação ser mais fixada e houvesse a memorização, utilizou-se dos números afixados separadamente e juntos construímos de 11-20. Para instigar a turma a aprender propôs-se o jogo da memória, produzido com bandeja de ovos e papel, usou-se tampinhas de garrafa para tornar mais prático e visível o jogo, visando a memorização dos números e sequencia, foi de fácil compreensão, porém assegurar a gestão de sala foi um desafio ante o comportamento dos alunos.
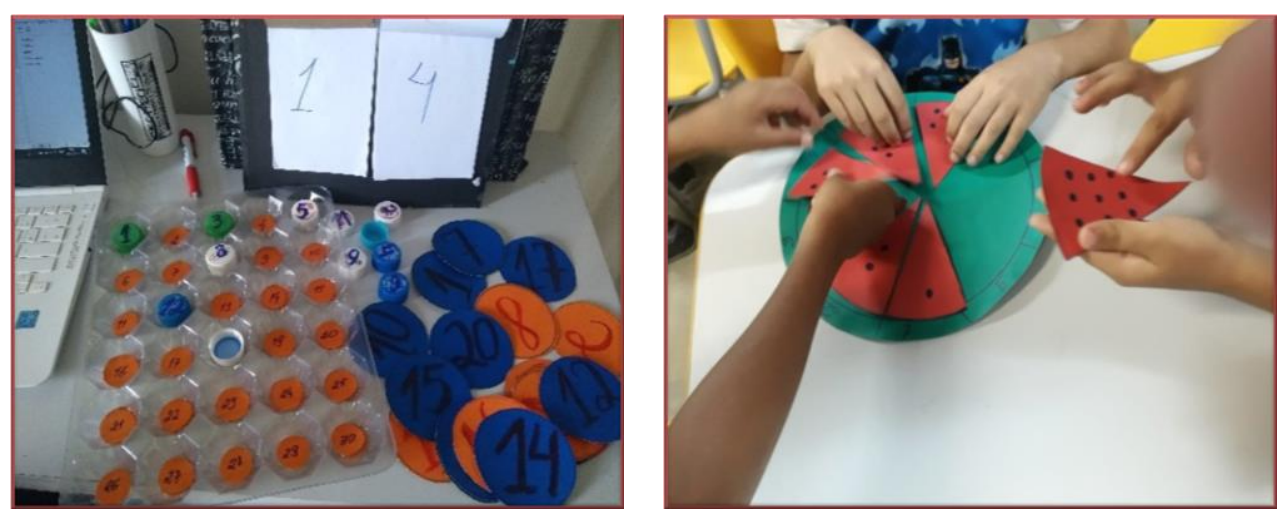

Fonte: arquivo da autora

No reforço de matemática, foi notado que havia alunos que não sabiam escrever os números, trabalhamos como escrever, posição de 1-10, para aperfeiçoar o aprendizado, usando a metodologia do jogo da 
melancia, as crianças deveriam preencher os espaços dos números conforme a quantidade de sementes desenhadas, divididas em equipes para melhor desenvolvimento da atividade. A dinâmica da aula foi prazerosa a professores e alunos, as respostas foram tão positivas que foi pedido mais jogos, foi bom ver os alunos interagindo e respondendo às perguntas que se faziam no decorrer da montagem da melancia. Objetivo: trabalhar com o concreto para maior assimilação.

Por decisão do colegiado foram fixados o reforço de matemática, assim continuamos realizando, de forma lúdica foi promovido o uso de plaquinhas de verdadeiro e falso para as questões de matemática que envolvia exemplos, problemas e reconhecimento dos números trabalhados 1-20. A participação foi ativa e criavam suas próprias perguntas, claro que houve inicialmente dificuldade de se concentrarem, a sala estava com 20 alunos e estavam bem agitados.

Foi realizado a revisão de todo o conteúdo de forma lúdica que objetivava a quantificação e identificação dos numerais. Usado para tal, feltro, linha, cabide e canudinhos plásticos. Houve interação entre as crianças que correspondiam os comandos e questões feitas. Embora a turma estivesse agitada além do cotidiano deles.

Ensinou-se como somar e as formas de organizar a mente para realizar somas e pensar mais prático além de contar nos dedinhos. A metodologia de chamar ao quadro e revisar no caderno se deu de aluno a aluno e de acordo com nível de compreensão desses. A maioria ainda precisa do concreto para assimilar e as operações matemáticas em sua estrutura ainda é muito complexa para eles. Porém Flor afirma que alguns avançaram e antes do tempo previsto, fato atribuído pela docente as intervenções lúdicas realizadas nas atividades de estágio.

Figura 3 - Caixa de continhas

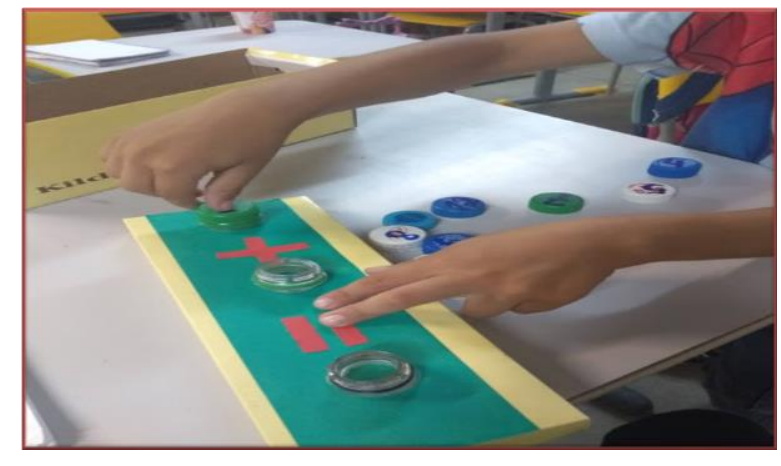

Fonte: arquivo da autora

Para rever o conteúdo de forma lúdica criou-se a "caixa das continhas", útil para montar as continhas e tornar a aula mais leve. Em seguida foi distribuída nova atividade impressa com contas e probleminhas. Correção no quadro do exercício e resolução coletiva.

\subsection{CONTEÚDOS DE GEOGRAFIA}

Nas aulas de Geografia, trabalhou-se lugar de moradias; os arredores da casa e da escola. A metodologia consistiu em: levar as crianças a um ponto da escola ao ar livre e observar os arredores; realizou-se uma conversa sobre suas moradias; o que percebem? Como parecem? Objetivando mostrar os diferentes tipos de moradias e identificar seus espaços em casa. Para fixar conteúdo a atividade foi escrita, que demandaria organizar os desenhos, identificar no desenho a moradia que mais parecia com a deles em seguida compartilhar em grupo.

Continuando o conteúdo sobre o lugar de moradia, o foco ampliou-se para minha cidade, estado e país. Trabalhou-se com auxílio do globo mundial e desenhos caracterizando a criança dentro desses espaços, objetivando mostrar que a geografia está em todo lugar; dentro de casa, nas diversas moradias de cada lugar, fala quem somos e como vivemos.

No conteúdo sobre lugares e paisagens, desenvolvemos mostrando diversas paisagens, ensinando sobre as regiões e diferenciações que se tem de lugar a outro, foi construído no quadro o desenho de uma paisagem com a participação dos alunos. 


\subsection{AS AULAS ESPORTIVAS}

Na aula Esportiva, trabalhou-se os membros superiores e inferiores; alto e baixo. Levou-se as crianças ao pátio da escola para realização de jogo de comando, usando balões passando e repassando com níveis de dificuldades entre os membros. As habilidades foram trabalhar as percepções de espaço; identificar direito e esquerdo do corpo; alto e baixo; membros superiores e inferiores; desenvolver a sociabilidade, entender comandos e regras.

Outra atividade esportiva trabalhou o raciocínio lógico, sociabilidade e aceitação de regras. De modo interdisciplinar utilizamos a matemática como recurso pedagógico que chamamos de varal dos números. O desenvolvimento se deu em dividir duas equipes, escolher um representante de cada, a equipe auxilia na resolução da atividade apoiando sem entrar no espaço do jogador. Seguindo o comando dado pela professora, o representante corre procurando o número e com um pregador fixa no varal. Ganha quem acerta mais números. 0 objetivo foi que compreendessem os comandos, interação entre eles de forma voluntaria e respeitosa.

Em outro momento idealizamos trabalhar direção esquerda e direta, lateralidade, permanecendo dentro da sala de aula pois o pátio já estava agendado para outra turma, a realização da atividade não teve tanto sucesso devido à falta de concentração das crianças, retornando do intervalo agitadas e a falta de espaço torna toda e qualquer proposta complexa.

\subsection{CONTEÚDOS DE HISTÓRIA}

Em História explicou-se a árvore genealógica, mostrando que cada um tem sua história. A estagiaria criou uma narrativa e contou um pouco da sua história e como é formado a família, para que entendessem o significado da árvore. 0 objetivo foi perceberem como é a formação da família (membros) e diferentes formações familiares; identificação da sua trajetória: bebê, criança, adultos e idoso. Com metodologia: Expositiva; material de apoio Árvore genealógica em papelão e cartolina; contação de história. Cada aluno foi convidado a fazer a própria arvore genealógica com nomes: avós, pais, irmãos, tios, em seguida responder o Caça-palavra. Ao fim como reforço promovemos segunda atividade para percepção de tempo: bebê, criança, adulto e idoso.

Discorreu-se sobre identidade e construção da autoimagem, objetivando com esse conteúdo da disciplina de história instigar a percepção de si e do outro; identificação das características de cada um, semelhanças e diferenças. Para o desenvolvimento desse conteúdo houve o uso de um espelho pequeno para cada aluno olhar-se e falar um pouco de si. Como atividade, dividiu-se os alunos em duplas e distribuído folhas a todos, foi pedido que observassem o rosto do colega e desenhassem as características. Foi uma tarefa complexa pois mexe com a autoimagem da criança, notou-se que as crianças não descrevem suas reais características, mas os traços do que é considerado bonito, tais como pele branca, nariz fino, cabelo liso, causou surpresa as respostas por exemplo do Aluno $\mathrm{Mel}^{8}$, que afirmou não gostar de se olhar, porque era feio. Mel é negro, com cabelo crespo, uma criança encantadora, inteligente, mas não é de sorrir e conversar com seus colegas.

Ao final das atividades do estágio, fizemos uma roda de conversa como nossa despedida, falamos sobre a importância que foram os dias que passamos com a turma. Esse momento foi como gratidão pelo espaço cedido pela professora, sua colaboração e compromisso de acompanhar cada uma de nossas ações. Para as crianças proporcionamos um momento de festa, para nós o momento foi de avaliar o trabalho feito, refletir sobre os desafios da docência e as aprendizagens construídas na aproximação com o campo de trabalho.

\section{REFLEXÕES SOBRE O ESTÁGIO CURRICULAR - ANOS INICIAIS DO ENSINO FUNDAMENTAL}

O Estágio nos Anos Iniciais do Ensino Fundamental foi essencial para distinção prática das metodologias, junção dos conhecimentos teórico-práticos obtidos durante o curso em Pedagogia, rompendo o discurso fragmentado que "só se aprende pedagogia na prática". Esse estágio foi um dos momentos mais importantes durante o curso, por permitir o encontro com a prática, saindo, portanto, da zona de conforto para os desafios do ato de planejar, dedicar tempo na confecção de material de apoio, correlacionar o planejamento docente as reais necessidades dos alunos e o planejamento da instituição.

${ }^{8}$ Nome fictício para preservar a identidade da criança 
Foi desafiador ao mesmo tempo que um alento por saber que as múltiplas habilidades facilitam a prática da pedagogia, percebidos com clareza no que discorreremos a seguir.

\subsection{A PSCICOMOTRICIDADE COMO BASE}

Durante o estágio estivemos dando continuidade as observações sobre como nossas ações pedagógicas influem no desenvolvimento ou o atraso intelectual da criança, considerando as intervenções em sala de aula de acordo com os conhecimentos obtidos da psicomotricidade.

A escolha da turma e faixa etária se deu por saber que o $1^{\circ}$ ano do Fundamental é um período de transição e amadurecimento das funções cognitivas, nessa maturação faz-se necessário um conhecimento pautado na promoção do desenvolvimento integral da criança. Muitas vezes em nossas escolas a promoção do desenvolvimento da criança fragmenta-se na alfabetização e na busca por melhor pontuação da instituição nos programas do governo Federal, atingir metas da Secretaria de Educação e até a busca de reconhecimento do profissional, esquecem o quão importante é a relação do corpo e mente para um processo de ensino-aprendizado que considere as necessidades individuais, assim como suas potencialidades, tudo para promoção do desenvolvimento integral da criança.

A psicomotricidade é um trabalho conjunto entre mente e corpo, proporcionando uma escolarização ampla e responsável, que enxerga a criança em sua singularidade e dispõe-se em práticas de valorização e respeito a cada etapa de seu desenvolvimento. 0 movimento é uma expressão da personalidade, resultante do que o indivíduo aprendeu do meio em que está inserido, não se restringe a um método ou uma técnica, mas um constante acompanhar educativo por meio do movimento. Mais usado durante a Educação Infantil, mas podendo influir na educação em diversas etapas do ensino de crianças, adultos e até idosos. Para a criança, abrange etapas importantes no desenvolvimento intelectual, social e psicomotor por meio de ações que auxiliam seu crescimento.

Durante o estágio foram pautados o despreparo dos profissionais observados acerca da definição dos elementos norteadores que ressaltam a importância da psicomotricidade para o desenvolvimento integral da criança, bem como as vantagens de aulas personalizadas às necessidades das crianças e melhor desenvolvimento das aulas e evidente que menos desgastes emocional e físico da árdua rotina nas salas de aula.

A Psicomotricidade é importante para o desenvolvimento físico e intelectual da criança no processo ensino-aprendizagem, objetiva a prática da pedagogia que traga significação a aprendizagem de forma que limites emocionais e físicos sejam diminuídos ou reeducados para uma evolução pessoal a longo prazo, nada mais é que o uso da ciência e suas técnicas para maior capacitação e desenvolver de novas ferramentas para que criança tenha maior desenvoltura intelectual e respeito as suas particularidades.

Não podemos fingir não perceber ou saber das dificuldades que muitos pedagogos possuem nas escolas, como falta de recursos financeiro para materiais na produção de jogos por exemplo, ou a falta de apoio de seus coordenadores para desenvolverem aulas que considerem o corpo, espaços e a pluralidade presente em sala. $\mathrm{O}$ fato é que ainda é um sonho ter a psicomotricidade como coluna nas ações pedagógicas, pois o dia a dia em sala de aula é regado de tantos desafios, tais como incivilidades que tomam boa parte do tempo das aulas, superlotação e os diversos projetos governamentais que o professor deve incluir em seus planos.

Tudo parece não funcionar quando se olha uma sala sem vida, sem produção, sem identificar seus sujeitos, por isso procurou-se apurar o olhar pedagógico e mediante os desafios vislumbrar e realizar o diferencial em sala de aula. Vê-se nos conhecimentos da psicomotricidade a junção dos conhecimentos práticos sobre o desenvolver de cada etapa de vida do indivíduo autores como: Piaget (1987), Wallon (1979), Dantas (1992), Oliveira (1997), Fonseca (1995) e Negrine (1995) demonstram a importância da Psicomotricidade para um fazer pedagógico em valorização das ações do profissional da educação que venha proporcionar desenvolvimento físico e intelectual da criança, assim como perceber as possibilidades e os limites da pedagogia no acompanhamento das crianças em suas especificidades.

\subsection{DESAFIOS QUE PERMANECEM NA SALA DE AULA}

No percurso das observações, coparticipações e regências foram certificados dois maiores desafios que influenciam diretamente nas ações pedagógicas: a não comunicação entre gestão e professores; incivilidades dos alunos. 
Todo esse itinerário dia após dia reflete diretamente na saúde mental e física do profissional, que se agrava pelo isolamento por não ter o apoio necessário do próprio sistema educacional (não se trabalha a saúde do profissional da educação) que não enxerga o professor como pessoa, coluna de sustentação desse processo de ensino aprendizado, para tanto necessita ser fortalecido e ter suas necessidades atendidas e consideradas. Referimo-nos à saúde física mesmo, pois há um desgaste não apenas na voz, mas em toda estrutura física.

A falta de comunicação entre gestão e professores, dificulta a rotina em sala de aula, as mudanças de horários e as circunstâncias do dia a dia quando não são repassados devidamente ao professor causam transtornos e desencontros de informações que acarretam em constrangimentos, ansiedade e insegurança. A escola é um sistema que só funciona se a comunicação for exercida constantemente, um trabalho de equipe, onde um depende diretamente do outro.

Essas questões acima refletem tanto na vida do docente como em sua prática e formação. A falta de diálogo, confiança no profissional e convivência, criam inseguranças e até dependência do professor, como se o seu papel estivesse restrito a receber por exemplo as informações e trabalhar apenas o que foi repassado. Cria-se mecanismo tanto de individualismo, como depreciação das potencialidades dos profissionais. 0 fato é que se tem visto um processo de formação mecânica tanto do docente quanto do conteúdo, visando uma organização e a busca por melhores resultados para a instituição.

Conforme Nóvoa (1992, p. 12) “ a formação de professores tem ignorado, sistematicamente, o desenvolvimento pessoal, confundindo "formar" e "formar-se", não compreendendo que a lógica da actividade educativa nem sempre coincide com as dinâmicas próprias da formação".

Essa linha de fazer do docente uma espécie de profissional dependente de formações ou indicações, de comandos de outros especialistas para realizar suas práticas distanciam do seu objetivo de ensinar, experimentar, de propor e ter sua autonomia dentro e fora de sala de aula. Para Apple e Jungck (1990, p. 156) apud Nóvoa (1992, p. 12)

A intensificação leva os professores a seguir por atalhos, a economizar esforços, a realizar apenas o essencial para cumprir a tarefa que têm entre mãos; obriga os professores a apoiar-se cada vez mais nos especialistas, a esperar que lhes digam o que fazer, iniciando-se um processo de depreciação da experiência e das capacidades adquiridas ao longo dos anos. A qualidade cede o lugar à quantidade. [...] Perdem-se competências colectivas à medida que se conquistam competências administrativas. Finalmente, é a estima profissional que está em jogo, quando o próprio trabalho se encontra dominado por outros actores.

Essa dinâmica também reflete nas crianças que não recebem devida atenção no espaço escolar, recebem um ensino mecânico, atropelando suas fases de desenvolvimento, que não considera a individualidade e perdem obviamente oportunidades de construírem elos entre o que se aprende na escola com suas outras vivências.

Nessa configuração a criança perde mais que o professor, pois seu tempo de desenvolvimento é comprometido de forma a seguir sempre correndo atrás do prejuízo. Aos docentes fica o apelo para se enxergarem como sujeitos com potencial de transformação da escola. Aos futuros professores a reflexão crítica para que não venham a replicar os erros notados e dispor-se a fazer a diferença dentro e fora dos muros das escolas!

\section{CONSIDERAÇÕES FINAIS}

O estágio angariou conhecimentos incalculáveis à formação da estagiária na profissão docente, permitindo uma ampla visão das funções do pedagogo no processo de ensino e aprendizado, oportunizou maior organização e segurança do fazer pedagógico, assim como foram proporcionadas situações desafiantes para uma vivência ampla no que se refere ao ensino nos anos iniciais e a promoção de uma educação que considere a criança em suas necessidades e potencialidades, e atendendo o papel do docente na construção de cidadãos, pois a educação vai além do alfabetizar.

Ressaltamos a importância de conhecimentos baseados na psicologia e da psicomotricidade que habilitaram práticas mais condizentes as reais necessidades da sala de aula atualmente, para uma atuação competente e respeitosa ao desenvolvimento integral da criança.

Reconhecemos as dificuldades de atuar nesta área, pois as experiências também mostram a quão árdua, estressante e mal remunerada é a profissão, requer sim muito conhecimento, condicionamento físico, 
aptidão para ensinar, ponderação, coordenação, pensar coletivamente e ter extinto de liderança. Embora tenha visto de perto o lado negativo, ressaltamos a satisfação de ser professora, o ato de ensinar vai além do domínio de conteúdo, mas quando se ensina, se reinventa, cria, molda e muda vidas, a educação tem potencial de transformar os sujeitos!

\section{REFERÊNCIAS}

[1] DANTAS, H. In: LA TAILLE, Y. e outros. "Do ato motor ao ato mental: a gênese da inteligência segundo Wallon", Piaget, Vygotsky, Wallon: teorias psicogenéticas em discussão. São Paulo, SUMMUS, 1992.

[2] FONSECA, Vitor da. Manual de observação psicomotora: Significação Psiconeurológica dos Fatores Psicomotores. Porto Alegre: Artes Médicas, 1995.

[3] BARBOZA, HORN. Organização do Espaço e do Tempo na Escola Infantil. In: CRAIDY, C. M. e KAERCHER, G. E. P. da S. (org). Educação infantil: pra que te quero? Porto Alegre: Artmed Editora, 2007. p. 67-80.

[4] LIBÂNEO, José Carlos. Democratização da escola pública: A pedagogia crítico-social dos conteúdos. 21a‥ ed. São Paulo: Loyola, 2006.

[5] NEGRINE, Airton. Aprendizagem e desenvolvimento infantil: psicomotricidade: alternativas pedagógicas. Porto alegre: Prodil, 1995.

[6] NÓVOA, António. - "Os professores e a sua formação". Lisboa : Dom Quixote, 1992. pp. 13-33

[7] OLIVEIRA, G.C. Psicomotricidade: educação e reeducação num enfoque psicopedagógico. Petrópolis, Vozes, 1997.

[8] PIAGET, Jean, 1896 - 1980. A formação do símbolo na criança: imitação, jogo e sonho, imagem e representação; tradução de Álvaro Cabral e Christiano Monteiro Oiticica. 4 ed. Rio de Janeiro; LTC, 2013.

[9] PIMENTA, Selma Garrido; LIMA, Maria Socorro Lucena. Estágio e docência. SP: Cortez 2004.

[10] PIMENTA, Selma Garrido. O estágio de professores: unidade teoria e prática? 3. ed. São Pauaio: Cortez, 1997.

[11] SAVIANI, Demerval. Escola e democracia. 24. ed. São Paulo: Cortez, 1991.

[12] SOUZA, Alexandra Fátima Lopes de. 0 espaço físico da educação infantil e o disciplinamento da criança. Atos de pesquisas em educação - PPGE/ME FURB. V. 6, n. 3, p. 797- 822, set/dez. 2011. TUSSI, Dorcas. Universidade Federal de Santa Maria,2011. Disponível: http://proxy.furb.br/ojs/index.php/atosdepesquisa/article/download/1568/1834.

[13] WALLON, Henri. Do ato ao pensamento - ensaio de psicologia comparada. Trad. De J. Seabra Dinis, Lisboa, Moraes Editores, 1979. 


\section{Capítulo 10}

O início de uma trajetória: A escolha profissional do curso de pedagogia e as representações sociais dos estudantes

\section{Thamyris Mariana Camarote Mandú \\ Maria da Conceição Carrilho de Aguiar}

Resumo: 0 objetivo deste estudo foi analisar os motivos de escolha do curso de Pedagogia pelos estudantes, buscando identificar as representações sociais atribuídas ao curso no momento de sua entrada na formação. Participaram da pesquisa 103 estudantes concluintes do curso de Pedagogia da UFPE, utilizando-nos do questionário como instrumento de coleta nessa fase da pesquisa. A análise dos dados foi realizada a partir da técnica de análise de conteúdo de Bardin. A partir dos resultados apresentados, foi-nos possível identificar uma grande diversidade de fatores e aspectos que influenciaram na opção pelo curso de Pedagogia, que nos auxiliaram a compreender que o processo de escolha do curso superior é permeado de características sociais, culturais, econômicas, de questões subjetivas, associadas às representações sociais da carreira profissional. 0 motivo de escolha do curso mais evidenciado pelos estudantes foi a identificação com a área de educação e com o curso de Pedagogia, sendo elencados outros fatores como, facilidade de entrada, influência familiar, complementar a formação inicial do curso Normal Médio, experiência na área de educação e de ensino, ampla área de atuação profissional, desejo de ensinar, entre outros. Consideramos que esses aspectos se combinam para formar um conjunto de valores, autoconceito, identificação, interesses e expectativas acerca do curso superior que se está escolhendo e de sua inserção profissional futura. Compreendemos, portanto, que a opção pelo curso superior é impulsionada por uma diversidade de fatores, de ordem pessoal, social e cultural, que podem influenciar na maneira como os estudantes concebem e vivenciam seu curso, constroem um sentimento de pertença àquela categoria profissional, criam expectativas (positivas ou negativas) acerca de sua profissão. Identificar as motivações dos sujeitos na escolha do curso permite uma aproximação ao entendimento das representações sociais compartilhadas por eles.

Palavras-chave: Curso de Pedagogia. Estudantes. Escolha profissional. Representações sociais. 


\section{INTRODUÇÃO}

Analisar os motivos e as condições determinantes do processo de decisão sobre o curso superior compreende levar em conta que tal processo não acontece de forma neutra e aleatória, mais que isso, torna-se fundamental a compreensão de que essa escolha pode ser determinada por fatores socioeconômicos, níveis e tipos de escolarização precedentes, práticas sociais e culturais compartilhadas, experiências profissionais anteriores, fontes e tipos de informações veiculadas na sociedade sobre o curso e seu campo profissional, influência de amigos e familiares, entre outros.

É importante destacar que esses fatores não irão influenciar de forma determinista a decisão sobre um curso universitário, entretanto considera-se que "as atitudes e escolhas dos indivíduos são tencionadas por saberes, valores e práticas socioculturais representativas de seus universos simbólicos" (SARAIVA \& FERENC, 2010, p. 3). Ou seja, essa escolha compreende um processo de tomada de posição guiado pelo sentimento de pertença social, pelos sistemas de referência sociais e simbólicos constitutivos do sujeito.

Segundo Moscovici (1978), as representações sociais guiam as ações, justificam as condutas e fornecem as noções teóricas sobre o objeto. As representações sociais que os futuros pedagogos têm de si, de sua futura inserção no mercado de trabalho e de sua função social podem ter orientado sua escolha pelo curso.

Ao longo do curso, no entanto, as representações socioprofissionais vão sendo delineadas, incorporarando as concepções prévias (do momento da escolha) e os valores e significados construídos durante a formação (JODELET, 2011).

Compreender a dinâmica que permeia a escolha profissional dos estudantes é levar em conta que sua inserção no mundo do trabalho é influenciada por fatores intrínsecos e extrínsecos, refletindo a atual realidade social, econômica, política e cultural da sociedade em que estão inseridos. Ao analisarmos a realidade brasileira, constatamos que a necessidade de rápida inserção no mercado de trabalho, assim como o desejo por melhores salários, ascensão social e estabilidade, é fator determinante na escolha de um curso de nível superior. As representações sociais sobre o curso e a profissão, por vezes, norteia os indivíduos nessa escolha, uma vez que estes possuem concepções quanto ao status da profissão, às condições de trabalho, às ocupações atribuídas àquela formação, à facilidade ou dificuldade de inserção no mercado de trabalho, etc.

A necessidade de identificar os motivos que levaram os participantes da pesquisa a escolher o curso de Pedagogia decorre do fato de que se configura de suma importância contextualizar o ingresso dos estudantes no curso, especificamente os motivos que os levaram a escolher esse curso como um dado essencial de análise e de auxílio no estudo de suas representações sociais acerca do campo de atuação do pedagogo, uma vez que essas representações não são apenas construídas durante o curso, ao contrário, muitas vezes a escolha baseia-se em representações já compartilhadas na sociedade, envolvendo também a definição sobre quem e o que o sujeito quer ser profissionalmente.

Jodelet (2011) entende que as representações sociais constituem fator importante no momento da escolha da formação acadêmica e profissional pelo indivíduo, podendo ser decisivas para o modo como os estudantes concebem seu curso, guiando também suas práticas. A referida autora ainda afirma que o estudo das escolhas profissionais ajudaria a compreender a dinâmica social e simbólica que sustenta a tomada de posição dos sujeitos, levando em conta sistemas de valores e ideologias específicas dos diversos campos; nesse sentido seria possível uma comparação intercultural e o conhecimento dos processos de gênese dessas representações.

Assim, a identificação dos motivos que levaram os estudantes a escolher o curso de Pedagogia apresentase como mais um fator que auxiliará na compreensão das atitudes e julgamentos de valor assumidos pelos sujeitos no processo de socialização e na construção de suas representações sociais sobre sua profissão e formação profissional.

Sendo assim, tivemos como objetivo, nesse recorte de pesquisa, analisar os motivos de escolha do curso de Pedagogia pelos estudantes, buscando identificar as representações sociais do curso no momento de sua entrada na formação, as fontes e os tipos de informações recebidas, as influências na escolha, bem como realizar um mapeamento dos fatores sociais, culturais e econômicos que perpassaram essa decisão. 


\section{METODOLOGIA}

Entendendo que, para a delimitação da metodologia a ser utilizada, o pesquisador deve levar em conta a especificidade de seu objeto, seus objetivos e seus pressupostos teóricos, a presente pesquisa orienta-se por um enfoque qualitativo fundamentado na teoria das representações sociais.

Participaram da pesquisa 103 estudantes concluintes ( $8^{\circ}$ e e 9o períodos) do curso de Pedagogia do Centro de Educação da Universidade Federal de Pernambuco, matriculados nos três turnos oferecidos (manhã, tarde e noite).

A coleta de dados foi realizada no primeiro semestre letivo do ano de 2012, sendo iniciada no mês de maio. 0 instrumento de coleta de dados utilizados nessa primeira fase da pesquisa foi o questionário, por possibilitar atingir um grande número de sujeitos e apresentar facilidade de aplicação, processo e análise. O questionário foi organizado em duas partes: a primeira visava traçar o perfil socioeconômico e cultural dos sujeitos investigados e a segunda tratava de questões referentes ao curso de Pedagogia, suas representações, motivos de escolha, fontes de informação sobre o curso, etc. Responderam ao questionário todos os estudantes que estavam presentes nas aulas em que foram aplicados.

A primeira parte do questionário permitiu realizar uma análise do perfil socioeconômico e cultural dos estudantes, com o intuito de conhecer melhor os estudantes que estão no curso de Pedagogia, caracterizando-os segundo gênero, faixa etária, turma, renda mensal, etc. Nessa etapa das análises utilizamos métodos estatísticos de cálculo de frequência e confecção de gráficos e tabelas que auxiliaram na interpretação dos dados, que foram categorizados e tratados com o auxílio do software Excel.

As demais questões dos questionários foram analisadas consoante a técnica de análise de conteúdo (BARDIN, 2009).

\section{A ESCOLHA PROFISSIONAL DO CURSO DE PEDAGOGIA E AS REPRESENTAÇõES SOCIAIS DOS ESTUDANTES}

\subsection{PERFIL DOS PARTICIPANTES}

Os estudantes pesquisados estavam matriculados no $8^{\circ}$ e 9 o períodos do curso de Pedagogia quando da coleta dos dados (período letivo de 2012.1). Dos 103 alunos, 60 cursavam o 8o período e 43, o 9o, distribuídos entre os três turnos oferecidos. 0 turno da noite apresenta maior quantitativo de estudantes matriculados $(44,7 \%)$, em seguida vem o turno da manhã $(37,8 \%)$ e, por último, o turno da tarde $(17,5 \%)$. É importante esclarecer que o turno da tarde só é ofertado em uma entrada por ano, enquanto os da manhã e noite são oferecidos nas duas entradas no momento do vestibular, ou seja, na primeira entrada são oferecidas duas turmas, uma no turno da manhã e uma no da noite, e na segunda entrada, há três turmas, manhã, tarde e noite. Por isso é possível perceber na tabela abaixo que só existem estudantes do 9o período nas turmas da manhã e da noite. Esse dado nos revela que a maior procura pelo turno noturno acontece pelo fato de possibilitar aos alunos exercerem outras atividades, principalmente trabalhar, durante os turnos da manhã e da tarde.

Os dados revelam uma predominância do gênero feminino entre os participantes, sendo 96 (93,2\%) estudantes do gênero feminino e apenas $7(6,8 \%)$ do gênero masculino. Os dados obtidos a respeito da faixa etária dos estudantes revelam que estes estão concentrados majoritariamente entre 20 e 29 anos, sendo constatado um quantitativo de $37,9 \%$ tanto na faixa etária compreendida entre 20 e 24 anos quanto na faixa etária de 25 a 29 anos. Se levarmos em consideração, que os estudantes participantes da presente pesquisa encontram-se nos períodos finais do curso e que seu ingresso aconteceu no ano de 2008, verificaremos que $23 \%$ dos ingressantes tinham entre 18 e 19 anos de idade no momento de sua entrada no curso, caracterizando uma entrada imediata ou quase imediata no Ensino Superior após a conclusão do Ensino Médio.

No que concerne ao tipo de escola que os estudantes frequentaram na educação básica, constatamos que há certo equilíbrio entre a quantidade de alunos que provêm de escola pública (40\%) e a dos que são provenientes de instituições privadas (39\%); o restante (22\%) teve uma formação mista, frequentando tanto escolas públicas como privadas.

Para complementar a discussão anterior, realizamos uma análise da renda familiar dos participantes da pesquisa, visto que são dados que nos dão subsídios para identificar a condição socioeconômica dos sujeitos. A maior parte dos estudantes possui renda familiar de 1 a 5 salários mínimos (69\%), em seguida vêm os alunos que se situam na faixa de renda de 6 a 10 salários mínimos (22\%); apenas 7\% dos discentes 
possuem renda familiar acima de 11 salários mínimos (sendo 5\% situados no intervalo de 11 a 20 e apenas $2 \%$ tendo renda maior que 21 salários mínimos).

Estudos de Monteiro (2005) e Braúna (2009) apontam que é possível perceber algumas mudanças no perfil do estudante de Pedagogia, indicando que, apesar de a classe social da maioria dos estudantes que procuram o curso de Pedagogia permanecer inalterada (classe baixa a média), está havendo um aumento de alunos provenientes de instituições privadas de ensino, embora reconheçam que tal fato causa certa estranheza quando se pensa que muitas vezes as escolas privadas, são consideradas para a elite, classe que não costuma procurar o curso de Pedagogia como opção de formação superior.

\subsection{A ESCOLHA DO CURSO DE PEDAGOGIA}

Ao procedermos à análise das motivações que levaram os estudantes a escolher o curso de Pedagogia, foinos possível identificar uma diversidade de fatores elencados, conforme podemos identificar, a seguir. A identificação com a área de educação ou com o curso de Pedagogia foi o motivo de escolha para 15\% dos estudantes, ao passo que $13 \%$ dos alunos disseram ter escolhido o curso no momento do vestibular pela facilidade de entrada (nota de entrada baixa, grande quantidade de vagas, baixa concorrência), a decisão sobre curso, decorrente da influência familiar, foi listada por $12 \%$ dos alunos; outros $11 \%$ afirmaram ter escolhido o curso de Pedagogia para complementar sua formação em Magistério (Normal Médio); 9\% dos participantes da pesquisa disseram que a experiência na área de educação e de ensino foi a causa da escolha pelo curso, a ampla área de atuação profissional foi citada por $7 \%$ dos estudantes; enquanto outros 6\% elencaram o desejo de ensinar como fator, as tentativas frustradas para outros cursos juntamente com o sentimento de despreparo para passar no vestibular para outras áreas foi o que justificou a escolha de $5 \%$ dos alunos.

Os restantes $22 \%$ dos estudantes citaram outros fatores que motivaram sua opção pelo curso, porém a frequência com que foram citados não obteve um quantitativo significativo dentro do universo dos participantes. Dentre os motivos categorizados como outros, merecem destaque as seguintes justificativas de escolha: o fato de o curso ser da área de humanas, o reconhecimento da importância social do pedagogo, a possibilidade de estudar no horário noturno, a possibilidade de rápida inserção no mercado de trabalho, ter uma formação de nível superior, gostar de crianças e vocação.

Observa-se que o motivo de escolha do curso mais evidenciado pelos participantes da pesquisa foi a identificação com a área de educação e com o curso de Pedagogia, como pode ser verificado nas falas das estudantes:

- Me identificar com a área educacional desde cedo e não queria focar em uma única área (História, Matemática, por exemplo) por isto optei por Pedagogia por abarcar todas essas áreas (A72);

- Porque era o curso com o qual eu tinha afinidade, o único que eu realmente queria (A65).

Estudos de Saraiva e Ferenc (2010), Braúna (2009) e Aquino (2011) apresentam resultados consonantes com os aqui apresentados, identificando a afinidade com a área de educação e com o curso de Pedagogia como fator decisivo na escolha do mesmo. Essa afinidade, nas pesquisas citadas, foi justificada pelos estudantes por já terem contato com a área, seja por formação inicial em curso Normal Médio ou por experiências na área de educação. Nossos achados aproximam-se dos dados apresentados, uma vez que 9\% dos sujeitos afirmaram ter experiência na área de educação, quer em atividades administrativas ou, especificamente, na docência, e 11\% explicitaram desejar complementar a formação do Magistério.

A facilidade de entrada foi relacionada como motivação de $13 \%$ dos discentes, que a atribuíram à baixa nota de ingresso no vestibular, à grande quantidade de vagas ofertadas e à baixa concorrência. É necessário salientar que o curso de Pedagogia da UFPE oferta, para o Campus de Recife, 250 vagas anuais no momento do exame vestibular, divididas igualmente em 5 turmas ( 2 na primeira entrada - manhã e noite; e 3 na segunda entrada - manhã, tarde e noite), constituindo-se no curso com maior quantidade de vagas, seguido pelos cursos de Direito (250 vagas), Ciências Contábeis (220 vagas) e Administração (200 vagas), todos no Campus Recife (MANUAL DO CANDIDATO, 2012). A baixa concorrência também é decorrente da vasta oferta de vagas, sendo essas duas variáveis diretamente relacionadas.

As falas de dois estudantes retratam essa realidade:

- Devido a quantidade de vagas que esse curso oferece (A26). 
- Quantidade de vagas, pouca concorrência, horário adequado, conhecimento da profissão (A48).

Gatti et al (2009) afirmam que os cursos de Licenciatura apresentam menor relação candidato/vaga em decorrência de uma não valorização e de um baixo prestígio social da carreira docente e do próprio curso de Licenciatura, bem como que os estudantes que optam por cursos de Licenciatura são, em sua maioria, oriundos de classes sociais de menor prestígio. Saraiva e Ferenc (2010) atribuem a essa decisão o fato de muitos dos discentes não terem sido aprovados em outros cursos que eram sua primeira opção, decidindo pelo curso de Pedagogia em virtude da facilidade de entrada.

Esses dados precisam também ser analisados levando em consideração o perfil socioeconômico dos participantes da pesquisa, já que foi constatado que a maior parte dos estudantes está situada numa classe social considerada baixa a média. Saraiva (2005), Aquino (2011) e Nogueira e Nogueira (2004) afirmam haver uma correlação entre a escolha pelo curso superior derivada da facilidade de acesso e o perfil socioeconômico dos estudantes, visto que pessoas oriundas de camadas sociais menos favorecidas tendem a realizar uma "autosseleção" no momento de escolher o curso de graduação que querem (e que podem) seguir. Essa autosseleção pode acontecer à medida que são escolhidos cursos que oferecem maior facilidade de ingresso, pois estes sentem-se despreparados para passar no vestibular de outros cursos mais valorizados socialmente que têm uma grande concorrência e necessitam de uma nota mais alta para entrada; além de que pessoas de classes sociais e econômicas mais baixas tendem a depositar no curso superior uma esperança de ascensão social e econômica e em decorrência disso não querem esperar muito para entrar na faculdade pública, razão por que procuram cursos com maior facilidade de ingresso que lhes permitem uma entrada quase que imediata no ensino superior público.

Esse dado apresenta grande relação com outro motivo de escolha citado pelos estudantes: tentativas frustradas e despreparo para outros cursos, conforme podemos identificar na fala de um dos participantes da pesquisa que diz que sua opção por Pedagogia aconteceu "porque a minha outra opção era na área de saúde e eu não me sentia preparada para o vestibular nesta área" (A27).

Assim, verificamos que a escolha do curso está inserida num contexto social de necessidade de uma formação de nível superior, mas que agregue características de possibilidade de acesso à universidade pública, rápida inserção no mercado de trabalho (uma vez que a inserção no curso permite a atuação profissional já nos primeiros períodos em atividades de estágio), alta taxa de empregabilidade, possibilidade de aprovação em concurso público que exija formação em nível superior, como observamos na fala de um dos estudantes quando inquirido sobre o motivo de ter escolhido o curso de Pedagogia: "Porque quero fazer concurso público que exige qualquer graduação" (A43).

Dentro desse contexto, destacamos outro condicionante de escolha valorizado pelos estudantes, a ampla área de atuação do pedagogo. $7 \%$ dos participantes da pesquisa relataram terem se motivado a escolher o curso de Pedagogia por julgarem amplas suas possibilidades de atuação profissional, como percebemos nas falas de alguns entrevistados:

- Por gostar de educação, e por perceber que a pedagogia oferece um campo amplo para atuação do profissional da educação (A70);

- Pela amplitude da atuação do pedagogo em atuar em outros espaços de trabalho, que não seja escolar (A75);

- Por ser um curso com uma amplitude de atuação (A23).

A concepção de uma ampla área de atuação como motivo de escolha está diretamente relacionada com o desejo de alguns estudantes de não seguir carreira docente, justificando sua escolha do curso de Pedagogia, um curso de licenciatura que tem como base a docência, pelo fato de lhes possibilitar a atuação em outros âmbitos que não a sala de aula ou a própria escola. Assim, o processo de escolha, mais uma vez, apresenta-se permeado de características sociais e individuais, porque os estudantes utilizam a graduação em Pedagogia como trampolim para a inserção profissional em outros âmbitos além da escola.

A não atratividade da carreira docente é tratada em alguns estudos (GATTI,1997; AQUINO, 2011; GATTI et al, 2009) e relacionada às condições salariais e de trabalho do professor da educação básica, ao status associado à profissão, à sua desvalorização, à carga excessiva de trabalho, quando se leva em conta o tempo despendido em planejamento, confecção e correção de atividades e provas, além da dupla jornada de trabalho que muitos professores enfrentam para complementar sua renda, trabalhando em dois ou mais turnos. 
Porém, em contrapartida, identificamos que para 6\% dos estudantes, o que influenciou sua escolha da graduação em Pedagogia foi o desejo de ensinar. Essa concepção deriva de um entendimento mais aprofundado acerca dos objetivos principais do curso e de seu funcionamento, assim como da referência social e histórica de que o curso de Pedagogia se destina a formar para a profissão docente, como também está diretamente relacionado a experiências profissionais prévias dos estudantes.

Constatamos que $52 \%$ dos discentes investigados exerciam atividade profissional no período em que prestaram vestibular para o curso de Pedagogia. Dentre os estudantes que trabalhavam, $39 \%$ realizavam atividades diretamente relacionadas à área educacional, como docentes, auxiliares de ensino, coordenação, e todos eles afirmaram que a atividade profissional realizada no momento de prestar vestibular influenciou em sua escolha do curso de Pedagogia. 0 restante dos estudante dedicava-se a outras profissões, como: atendentes de call center, auxiliares administrativos, secretárias, comércio, entre outros.

Percebemos que são ocupações um pouco distantes da área educacional, que não exige conhecimentos específicos da área, e também que, em geral, trata-se de atividades de baixo prestígio social e que não costumam ter uma remuneração elevada, o que indica uma relação com a classe socioeconômica em que esses estudantes estão inseridos e a necessidade de inserção no mercado de trabalho mesmo antes de uma formação em nível superior, para, muitas vezes, ajudar na renda da família. Esses resultados indicam a necessidade de os sujeitos ingressarem numa graduação e, ao mesmo tempo, a relação entre sua situação socioeconômica e a escolha de um curso de menor prestígio, mas que proporcione uma garantia maior de ingresso do que outros cursos de maior prestígio que tendem a apresentar maior concorrência, maiores notas de entrada e maiores dificuldades de ingresso.

A influência familiar foi citada por $12 \%$ dos estudantes como motivação para escolher o curso, conforme revelam os fragmentos a seguir:

- Essa área está em minha família em muitas gerações: minha mãe é professora (pedagoga), minha avó foi professora (formada em história) e minha bisavó foi normalista (A2);

- Por já possuir pedagogos na família, além de ter uma escola da minha mãe considerei importante continuar na área de atuação da família e me aperfeiçoar (A12);

- Influência da família. Pai professor universitário, mãe psicopedagoga (A18).

Consideramos, dessa forma, que a escolha profissional do sujeito é perpassada também pelos modelos familiares, que exercem uma grande carga de influência nessa escolha, permeada por valores e perspectivas acerca das profissões, articuladas também com a atuação desses familiares na área de educação.

Dentro desse processo de escolha do curso de Pedagogia, é importante apreender as fontes de que os estudantes se utilizaram para obter informações acerca do referido curso. As principais fontes de informação sobre o curso foram os familiares e amigos (26\%), vindo depois internet (22\%), escola ou professores do Ensino Médio (13\%), estudantes ou egressos do curso (9\%), manual do vestibular (5\%), jornais e revistas (4\%), curso de Magistério (4\%), livros (2\%), feira de profissões (1\%), além de uma quantidade significativa de estudantes que afirmaram não ter qualquer tipo de informação sobre o curso $(14 \%)$.

Percebemos a extrema ligação entre a predominância da família e de amigos como fonte de informações sobre o curso e a já discutida influência familiar na escolha da graduação em Pedagogia. Percebemos uma certa orientação vocacional dos estudantes que citam a escola e professores do Ensino Médio como fonte de informação. A formação no Magistério pode ser relacionada à discussão anterior que realizamos sobre a influência da formação anterior ao curso no processo de escolha.

Corroborando nossos dados, encontramos o estudo de Saraiva e Ferenc (2010) que citam como fonte de informação principal dos sujeitos a família e amigos, identificando outras fontes, como revistas, jornais, orientação vocacional.

Além dessas fontes, alguns estudantes citaram que tipo de informações receberam sobre o curso, como podemos verificar nos enunciados dos estudantes: 
- Tinha muitas vagas e era um curso pra ser professora (A5);

- Não tinha muitas informações, mas sabia que era para desenvolver atividades com educação (A10);

- As piores possíveis. 1- Grande carga horária de trabalho. 2- Baixo salário (A42).

Esses aspectos podem ser diretamente relacionados com os motivos de escolha já citados e explorados ao longo de nossas análises, e retratam o tipo de informação que permeia o pensamento social acerca do curso de Pedagogia: voltado para a formação docente, com muitas vagas, mas, ao mesmo tempo, que a atuação profissional demanda uma grande carga de trabalho e que é pouco remunerada.

Outro aspecto que merece ser destacado é que para $82 \%$ das estudantes o curso de pedagogia não foi sua única ou primeira opção de escolha no momento de prestar vestibular. Alguns estudantes afirmaram ter prestado vestibular anteriormente e, por não terem conseguido aprovação em outros cursos, resolveram tentar a graduação em Pedagogia no vestibular seguinte; outros disseram que, no momento do vestibular, tinham interesse em outro curso, mas optaram por Pedagogia. Os principais cursos citados foram Psicologia (20\%), História (19\%), Serviço Social (12\%), Letras (9\%), Direito (7\%), Jornalismo (7\%), Geografia (6\%) e Administração (5\%). Os demais cursos elencados pelos estudantes foram categorizados como outros por terem, individualmente, baixas frequências, representando, no total, $33 \%$ dos estudantes. No geral foram cursos das áreas de saúde, de exatas e de ciências sociais aplicadas (segundo categorização de áreas da CAPES e do CNPQ).

Esses dados ratificam nossas análises sobre a escolha do curso de Pedagogia, articulando-se com vários aspectos já destacados na presente pesquisa, como o sentimento de despreparo para prestar vestibular para outros cursos, a facilidade de ingresso no curso, o desejo de atuar em outros âmbitos que não o escolar. As tentativas frustradas e o próprio sentimento de despreparo para ingressar em outros cursos através de exame vestibular constituem-se como grande influência na escolha do curso de maneira secundária, relacionando-se diretamente com motivos já citados pelos estudantes para a escolha do curso.

\section{CONSIDERAÇõES FINAIS}

A partir dos resultados apresentados, foi-nos possível identificar uma grande diversidade de fatores e aspectos que influenciaram na opção pelo curso de Pedagogia, que nos auxiliaram a compreender que o processo de escolha do curso superior é permeado de características sociais, culturais, econômicas, de questões subjetivas, associadas às representações sociais da carreira profissional. Segundo Saraiva e Ferenc (2010), tais fatores "são esclarecedores no entendimento de que as RS articulam várias funções nos grupos sociais, como a função de saber, a identitária, a avaliativa e a reguladora das práticas sociais" (p. 9). Portanto, consideramos que esses aspectos se combinam para formar um conjunto de valores, autoconceito, identificação, interesses e expectativas acerca do curso superior que se está escolhendo e de sua inserção profissional futura.

Entendemos, então, que as representações sociais constituem-se dentro de um contexto social permeado por valores, práticas sociais, experiências prévias, processos comunicativos que irão formar o conjunto de saberes relacionados a determinado objeto social que permite ao grupo compreender a realidade a partir de um sistema de referência próprio, atribuindo sentido às suas condutas, definindo sua identidade e legitimando as tomadas de posição e os comportamentos adotados (MOSCOVICI, 1978).

Compreendemos, portanto, que a opção pelo curso superior é impulsionada por uma diversidade de fatores, de ordem pessoal, social e cultural, que podem influenciar na maneira como os estudantes concebem e vivenciam seu curso, constroem um sentimento de pertença àquela categoria profissional, criam expectativas (positivas ou negativas) acerca de sua profissão, bem como vão retratar os valores, os significados, os julgamentos e a identificação dos sujeitos com o curso escolhido (SARAIVA \& FERENC, 2010; BASíLIO, 2012). Identificar as motivações dos sujeitos na escolha do curso permite uma aproximação ao entendimento das representações sociais compartilhadas por eles.

\section{REFERÊNCIAS}

[1] AQUINO, S. L. de. O pedagogo e seus espaços de atuação nas representações sociais de egressos do curso de Pedagogia. Dissertação de Mestrado, Universidade Federal de Viçosa, Programa de Pós-Graduação em Educação, Minas Gerais. 2011

[2] BARDIN, L. Análise de Conteúdo. 4.ed. Lisboa: Edições 70, 2009. 
[3] BASÍLIO, M. A. T. O curso de Pedagogia nas representações sociais dos seus estudantes. Dissertação de Mestrado, Universidade Federal de Pernambuco, CE, Programa de Pós-Graduação em Educação, Recife. 2012.

[4] BRAÚNA, R. C. A. A construção de identidades profissionais de estudantes de Pedagogia. In: 32a Reunião Anual da ANPEd, 2009, Caxambu. Sociedade, Cultura e Educação: Novas Regulações?. GT-08. Disponível em: <http://www.anped.org.br/reunioes/32ra/arquivos/posteres/GT08-5280--Int.pdf >. Acesso em: 21/07/2010.

[5] GATTI, B. A. Formação de professores e carreira: problemas e movimentos de renovação. Campinas, SP: Autores Associados, 1997.

[6] GATTI, A. B. et al. A atratividade da carreira docente no Brasil. In: Estudos \& Pesquisas EducacionaisRelatório Final - São Paulo: Fundação Victor Civita, 2009. (Relatório de Pesquisa).

[7] JODELET, D. Ponto de vista: Sobre o movimento das representações sociais na comunidade científica brasileira. Temas em Psicologia, v. 19, n. 1, pp. 19 - 26, 2011.

[8] MONTEIRO, I. A. Formação inicial de profissão docente: as Representações Sociais dos alunos do curso de Pedagogia da Universidade Federal de Pernambuco. Recife: Editora Universitária da UFPE, 2005.

[9] MOSCOVICI, S. A representação Social da Psicanálise. Rio de Janeiro: Zahar Editores, 1978. Trad. Álvaro Cabral.

[10] NOGUEIRA, M. A.; NOGUEIRA, C. M. Bourdieu \& a Educação. Belo Horizonte: Autêntica, 2004.

[11] SARAIVA, A. C. L. C. Representações sociais da aprendizagem docente de professores universitários em suas trajetórias de formação. Tese de doutoramento. Universidade Federal de Minas Gerais, 2005.

[12] SARAIVA, A. C. L. C; FERENC, A. V. F. A escolha profissional do curso de Pedagogia: análise das representações sociais de discentes. In: 33ª Reunião Anual da ANPEd, 2010, Caxambu. Educação no Brasil: O Balanço de uma Década. GT-08.

[13] SARAIVA, A. C. L. C.; REIS, C. L.; OLIVEIRA, M. A. As representações sociais dos discentes do curso de pedagogia de uma instituição de minas gerais: fatores de influência no processo de escolha profissional. In: XV ENCONTRO NACIONAL DA ASSOCIAÇÃO BRASILEIRA DE PSICOLOGIA SOCIAL, 2009, Maceió. Disponível em: <http://www.abrapso.org.br/siteprincipal/images/Anais_XVENABRAPSO/395.\%20as\%20representa\%C7\%D5es\%2 0sociais\%20dos\%20discentes\%20do\%20curso\%20de\%20pedagogia\%20de\%20uma\%20institui\%C7\%C3o.pdf>. Acesso em: 21/07/2010. 


\section{Capítulo 11}

\section{Inclusão em educação na formação docente em biologia}

\section{André Fillipe de Freitas Fernandes \\ Débora de Aguiar Lage}

Resumo: A inclusão escolar dos alunos com deficiência envolve o emprego de diferentes práticas pedagógicas, a fim de favorecer o processo de ensino-aprendizagem. Neste contexto, na busca por uma educação realmente inclusiva, torna-se urgente o desenvolvimento de estratégias didáticas especializadas, capazes de contribuir para a construção do conhecimento de todos os estudantes, sem distinção. Este artigo apresenta um trabalho no qual foram adotadas diferentes modalidades didáticas, buscando articular a aprendizagem teórica e prática à perspectiva inclusiva. 0 estudo foi desenvolvido com cerca de 20 estudantes do ensino médio de um colégio estadual do Rio de Janeiro com deficiências intelectual, visual e com alunos surdos. Considerando as diferenças e especificidades de cada deficiência, foi necessário adaptar a metodologia de acordo com a melhor forma de aprendizado peculiar à cada grupo. Diferentes tipos de materiais didáticos foram elaborados e/ou adaptados a fim de atender as especificidades de aprendizagem desses estudantes. Além disso, durante os encontros semanais, estratégias de abordagem diversificadas foram empregadas, visando favorecer a construção de conceitos e contribuir para o processo de aprendizagem. Neste sentido, a verdadeira inclusão em educação implica no rompimento de paradigmas, a fim de assegurar a equidade nos métodos de ensino, aprendizagem e avaliação. Acreditamos que as experiências vivenciadas pelos licenciandos favoreçam a formação de um professor comprometido com a sua função social de educar igualmente todos os estudantes, promovendo uma educação de qualidade e com respeito às diferenças.

Palavras-chave: Atendimento educacional especializado. Educação especial. Inclusão em educação. 


\section{INTRODUÇÃO}

A discussão sobre a inclusão educacional ganhou maior repercussão a partir da década de 1990, principalmente na área da educação, no campo das Ciências Humanas, devido à pressão dos movimentos sociais em defesa das pessoas com deficiência e a publicação de alguns documentos internacionais e nacionais de Políticas Públicas de Educação Inclusiva. Neste sentido, as práticas escolares inclusivas aqui discutidas têm como objetivo a construção de uma escola acolhedora, onde não existam critérios ou exigências de natureza alguma, nem mecanismos de seleção ou discriminação para o acesso e a permanência com sucesso de todos os estudantes.

Para discutir tais questões faz-se premente apresentar, ainda que brevemente, o papel que a escola desempenha hoje na sociedade no âmbito da inclusão escolar. Compreendemos que a escola, como parte constituinte da sociedade moderna, assume papel relevante na consolidação de determinados "traços" sociais, na qual gestores e professores devem propiciar a inclusão de minorias, historicamente excluídas (CROCHÍK, 2015). Nessa perspectiva, a inclusão aparece como propulsora de uma nova visão de escola, na qual, sob a narrativa do respeito às diferenças, oportuniza-se uma democratização da educação (ROCHAOLIVEIRA; MACHADO; SIQUEIRA, 2017).

Neste contexto, nos últimos anos, mudanças significativas foram observadas no âmbito educacional, especialmente no que se refere à inclusão de pessoas com deficiência, que por muito tempo não possuíam o direito garantido de frequentar o ensino regular. No Brasil, dentre os alunos com deficiência que passaram a ter acesso à escola, destacamos os estudantes com diferentes tipos de deficiências, transtornos globais de desenvolvimento e altas habilidades (BRASIL, 2008).

Segundo Bueno (2008, p.49), "a inclusão escolar refere-se a uma proposição política em ação, de incorporação dos alunos que tradicionalmente têm sido excluídos da escola, enquanto que a inclusão na educação se refere a um objetivo político a ser alcançado". Neste contexto, Breitenbach (2016, p. 366) ressalta que a "Educação Especial enquanto área de conhecimento e modalidade de ensino não se restringe aos processos de inclusão escolar do seu público na escola comum". Deste modo, a educação inclusiva é objetivo político para ser alcançado a curto, médio e longo prazo, por meio de inúmeras ações que favoreçam as diferentes formas de aprendizado, assegurem o respeito às diferenças e valorizem a diversidade humana (BUENO, 2008).

Do ponto de vista da legislação, diversos documentos foram produzidos a fim de estabelecer os princípios básicos de como a educação inclusiva deveria ser trabalhada nas escolas (VAZ et al., 2012). Dentre estes, destaca-se a Declaração de Salamanca, de 1994, um importante marco legal, político e pedagógico, que assegura, entre outras particularidades, que a matrícula de todas as crianças com deficiência deva ser realizada em escolas regulares e propõe as escolas o desafio de promoverem um ensino de qualidade, desenvolvendo um planejamento centrado nas necessidades da criança, a fim de educar a todos (UNESCO, 1994).

Complementar à Declaração de Salamanca, a constituição federal a partir da Lei 13.146 Institui a Lei Brasileira de Inclusão da Pessoa com Deficiência de 2015, destinada a assegurar e a promover, em condições de igualdade, o exercício dos direitos e das liberdades fundamentais por pessoa com deficiência, visando à sua inclusão social e cidadania. Em seu artigo 27 a lei destaca que:

A educação constitui direito da pessoa com deficiência, assegurados sistema educacional inclusivo em todos os níveis e aprendizado ao longo de toda a vida, de forma a alcançar o máximo desenvolvimento possível de seus talentos e habilidades físicas, sensoriais, intelectuais e sociais, segundo suas características, interesses e necessidades de aprendizagem (BRASIL, 2015).

Em seu artigo 28, a mesma lei incumbe ao poder público assegurar, criar, desenvolver, implementar, incentivar, acompanhar e avaliar o sistema educacional.

Para a construção de uma escola efetivamente inclusiva, é fundamental que haja um processo de ressignificação de concepções e práticas no ambiente escolar, na qual os educadores e os que estão em formação, passem a compreender a diferença humana em sua complexidade (FONSECA-JANES, 2010). Para tal, a escola precisa romper com certos paradigmas, uma vez que os métodos tradicionais de ensino, aprendizagem e avaliação dos estudantes não contribuem para assegurar uma educação para todos (FERREIRA, 2015). 
Diante das diversas dificuldades encontradas no cotidiano escolar, torna-se um desafio promover um ensino de qualidade para os estudantes com deficiência, onde a maioria dos docentes relata não ter capacitação para oferecer um atendimento educacional especializado para estes alunos (ROCHAOLIVEIRA; MACHADO; SIQUEIRA, 2017). Sem formação adequada, muitos professores não conseguem vislumbrar as potencialidades dos alunos com deficiência, o que resulta em baixa expectativa em relação a estes educandos (PIETRO, 2006; NUNES e LOMÔNACO, 2010).

Com efeito, para que a inclusão se torne uma realidade nas escolas brasileiras, é fundamental que haja uma mudança de perspectiva na formação inicial de professores, a fim de garantir a inserção de conteúdos e de práticas pedagógicas inclusivas no currículo dos cursos de licenciatura (OLIVEIRA et al., 2011; PEREIRA et al., 2018; SANTOS, 2018). No que tange ao ensino de Ciências e Biologia, diversos autores destacam a dificuldade dos professores na condução de atividades pedagógicas com estudantes com deficiência (PEDROSO; CAMPOS; DUARTE, 2013; ROCHA-OLIVEIRA; MACHADO; SIQUEIRA, 2017; LIMA e SILVA, 2018), especialmente nos primeiros anos de profissão.

Neste sentido, o presente artigo apresenta um trabalho de caráter multidisciplinar, de relevância para educador e educando, no qual foram adotadas diferentes modalidades didáticas, especializadas ou adaptadas, buscando articular a aprendizagem teórica e prática à perspectiva inclusiva. 0 estudo foi desenvolvido pelos licenciandos bolsistas do subprojeto de Ciências Biológicas, do Instituto de Aplicação Fernando Rodrigues da Silveira (CAp-UERJ), do Programa Institucional de Bolsas de Iniciação à Docência (PIBID/Capes/UERJ).

\section{METODOLOGIA}

A metodologia descrita nesta pesquisa apresenta um caráter qualitativo, na qual os pesquisadores buscam realizar uma abordagem voltada para o comportamento, a interpretação, as experiências vividas e a relação com o ambiente das pessoas que estão sendo estudadas (MINAYO, 2012). Desta forma, buscou-se melhorar a qualidade do ensino para estudantes com deficiência, a partir da confecção e da adaptação de diferentes materiais didáticos.

0 estudo foi desenvolvido na sala de recursos e nas salas de aulas de um colégio da rede pública estadual do Rio de Janeiro com cerca de vinte estudantes do ensino médio com deficiências intelectual, visual e com alunos surdos. As atividades foram realizadas em encontros semanais, algumas no contra turno e outras em horários vagos, as quais ocorreram em parceria com todos os professores que repassam para a sala de recursos o conteúdo aplicado em sala de aula, bem como os deveres e as revisões a serem conduzidas com os estudantes.

\section{RESULTADOS E DISCUSSÃO}

A inclusão pode ser descrita como um fenômeno social complexo, resultado de ações que são estabelecidas e mantidas por diferentes instituições, entre elas o governo, as instituições formadoras de educadores, as escolas, as pessoas com deficiências e suas famílias (SCHIMIDT, 2001). 0 conjunto de algumas dessas ações, principalmente as apresentadas pelos segmentos escolares, podem possibilitar o desenvolvimento pleno de crianças com deficiência, dependendo diretamente da oportunidade de acesso à informação, orientação e suporte que o professor e a escola oferecem (PICCOLO, 2009; PIMENTEL, 2013; SANTOS, 2018; ROCHA-OLIVEIRA; DIAS; SIQUEIRA, 2019). Neste estudo, a inclusão passou a se tornar passível de discussão a partir do planejamento de atitudes a serem apresentadas por todas as pessoas que compõem o contexto escolar.

Como consequência das ações implementadas foi possível estabelecer condições para que fossem observadas mudanças nas atitudes da comunidade escolar. Os resultados registrados a partir desta situação demonstram que, embora a inclusão de pessoas com deficiência seja apresentada enquanto lei, a capacitação docente assim como o suporte de estrutura e de materiais adequados que essa prática demanda, ainda são insuficientes (FERREIRA, 2015).

A partir disso, é importante destacar que inclusão não se faz dando somente acessibilidade, mas as condições de amparo, logística e aperfeiçoamento, as quais complementam e realizam a verdadeira inclusão. Em outras palavras, Neri e colaboradores (2003) relataram que:

A educação especial [...] visa oferecer escolaridade, apesar de segregar os indivíduos com necessidades educativas especiais. Já a educação 
inclusiva, não é apenas a simples colocação em sala de aula, significa a criação de uma escola onde pessoas com e sem deficiência possam conviver e estudar em ambientes onde os indivíduos aprendam a lidar com a diversidade e com a diferença [...] A educação inclusiva não deve ser confundida com a proposta de integração na rede regular quando apto para isso. É sim a inserção em uma escola ou classe que reconhece e valoriza a heterogeneidade dos alunos procurando desenvolver as suas diferentes potencialidades, através de uma prática de ensino flexível e diferenciada que busca o que há de melhor em cada um, suas aptidões, independente da condição portador ou não de deficiência, sem fórmulas de ensino ou propostas pedagógicas de ensino apartado (NERI et al., 2003, p 81).

Deste modo, propõe-se que as práticas desenvolvidas pelos licenciandos sejam capazes de aprimorar a aprendizagem para os alunos com deficiência, partindo do princípio que estas ferramentas aproximam o conteúdo da imaginação destes alunos, tornando a aprendizagem significativa para ambas as partes, alunos e licenciandos.

Uma vez que na sala de recursos e na escola existe uma grande diversidade de alunos, é fundamental haver uma pluralidade nas estratégias de abordagens. Vale lembrar, que mesmo a sala de recurso sendo um dos poucos espaços a trabalhar em cima da deficiência, a inclusão de cada um faz parte do processo, como afirma (MANTOAN, 1998, p. 30-32): "A meta da inclusão é, desde o início, não deixar ninguém fora do sistema escolar, que, por sua vez, terá de se adaptar às particularidades de todos os alunos". Essa inserção deve garantir o respeito às diferenças, saber que as pessoas aprendem de forma diferente. Assim, o processo ensino-aprendizagem com a educação inclusiva precisa estar aberto a mudanças (ROCHAOLIVEIRA; DIAS; SIQUEIRA, 2019). Desta forma, diversos autores têm reportado que a ausência de formação especializada e de materiais didáticos adaptados para alunos com deficiência constituem os principais obstáculos enfrentados pelos professores (GOLÇALVES et al., 2013; CARNEIRO e UEHARA, 2016; ROCHA-OLIVEIRA; DIAS; SIQUEIRA, 2017; LIMA e SILVA, 2018).

\subsection{PRODUÇÃO E ADAPTAÇÃO DE MATERIAIS DIDÁTICOS}

Diferentes materiais didáticos adaptados para alunos com deficiência visual e surdos foram confeccionados, a fim de atender as especificidades de aprendizagem desses estudantes. Segundo Brasil (2008), a elaboração de recursos pedagógicos para os alunos com deficiência é essencial para que o conteúdo apresentado se enquadre às necessidades específicas da deficiência do estudante. Assim, todos os materiais didáticos adaptados produzidos, foram confeccionados com materiais de baixo custo e de fácil percepção para estudantes com deficiência visual e auditiva. Entretanto, é importante destacar que muitas vezes, ao buscar ferramentas para a adaptação de materiais, o professor propicia um ambiente inclusivo que favorece a construção de conceitos de todos os estudantes, com deficiência ou não (BERTALLI, 2010; GONÇALVES, 2013).

Para os alunos com deficiência visual foi confeccionado um material didático com o auxílio de uma máquina thermoform, a qual emprega calor e vácuo para produzir relevo em uma película de policloreto de vinila (PVC). 0 material confeccionado representou uma árvore, seus respectivos órgãos e o solo onde se encontra, utilizando diferentes formas e texturas, a fim de favorecer o reconhecimento e a percepção tátil do aluno com deficiência visual. Neste caso, para sua composição foram empregadas miçangas do tipo canudinhos para caracterizar as raízes, papel corrugado para representar o caule, tecido liso para retratar as folhas, florzinha de borracha para simbolizar as flores, miçangas arredondadas para os frutos, linha de lã para delimitar a copa da árvore e papel de lixa para simbolizar um solo arenoso (Figura 1A).

A diversidade do grupo dos artrópodes foi representada a partir da adaptação de modelos didáticos comercializados, os quais apresentavam características fundamentais para a compreensão deste grupo, como estruturas proporcionais, com formas e texturas diversificadas, representando as distintas partes do corpo do animal. Contudo, a fim de promover a autonomia do estudante na percepção e no pleno entendimento sobre o material analisado, os modelos foram apoiados sobre placas feitas com papel cartolina contendo a classificação taxonômica do animal impressa em BRAILLE e em língua portuguesa com fonte ampliada, para atender os alunos de baixa visão (Figura 1B).

Para os alunos surdos, foi elaborado uma espécie de cartilha impressa para favorecer o estudo sobre os insetos. Neste material, foram inseridas algumas imagens de insetos, seus respectivos nomes populares 
escritos em língua portuguesa, além de diversas imagens caracterizando os insetos representados, a partir da Língua Brasileira de Sinais (LIBRAS), considerada a primeira língua de um grande grupo de surdos. As imagens com a língua de sinais foram obtidas a partir do aplicativo Hand talk (https://handtalk.me/), disponível gratuitamente para o sistema operacional iOS e Android. Além disso, foi adicionado à cartilha um pequeno texto escrito de forma simples e objetiva, a fim de aprofundar o conteúdo sobre os insetos e facilitar o aprendizado dos estudantes, que estarão interpretando a língua portuguesa, considerada L2 para a maioria dos alunos surdos (Figura 1C).

Um modelo de biscuit representando a genitália interna feminina também foi elaborado para os estudantes surdos. Neste caso, foi produzido um útero em corte longitudinal, mostrando o endométrio desenvolvido com a presença de um embrião em processo de nidação. Adicionalmente, foram modeladas as tubas uterinas, os ovários e seus ligamentos, onde um dos ovários também foi representado em corte longitudinal, exibindo os folículos ovarianos (Figura 1D). É importante destacar que para os estudantes surdos, a diversidade de formas e cores é fundamental para a compreensão dos modelos didáticos, uma vez que informações textuais, principalmente utilizando termos técnicos, não contribuem para o entendimento do objeto de estudo.

Entretanto, na contramão da necessidade de adaptação de materiais didáticos, está a ausência de formação especializada da maioria dos professores atuantes no ensino regular. Sobre a falta de capacitação dos docentes, Gonçalves e colaboradores (2013, p. 265) destacam que "a formação clássica do professor pressupõe a existência de uma metodologia de ensino universal para esses alunos considerados ideais ou normais". Assim, para que haja uma consolidação do que estabelece as leis, é essencial que os educadores estejam preparados para uma nova realidade, que é a de lidar com as diferenças e, principalmente, as limitações e singularidades de cada estudante, uma vez que a maioria dos docentes são formados para atuar de forma excludente (REIS e SILVA, 2012; PLETSCH, 2014).

Sobre a falta de capacitação docente, Freire (1996, p. 23) faz uma interessante reflexão a partir de um jogo de palavras, dizendo que "[...] quem forma se forma e re-forma ao formar e quem é formado forma-se e forma ao ser formado". Em outras palavras, Freire (1996) considera a formação continuada como elemento integrante da vida profissional do educador, daquele que forma, pois ao se re-formar encontrase em um novo processo da prática escolar e de si mesmo.

Figura 1 - Materiais didáticos adaptados para estudantes com deficiência visual e auditiva.

Legenda: A- Árvore e seus órgãos produzidos em thermoform; B- Modelos de artrópodes adaptados com legenda em

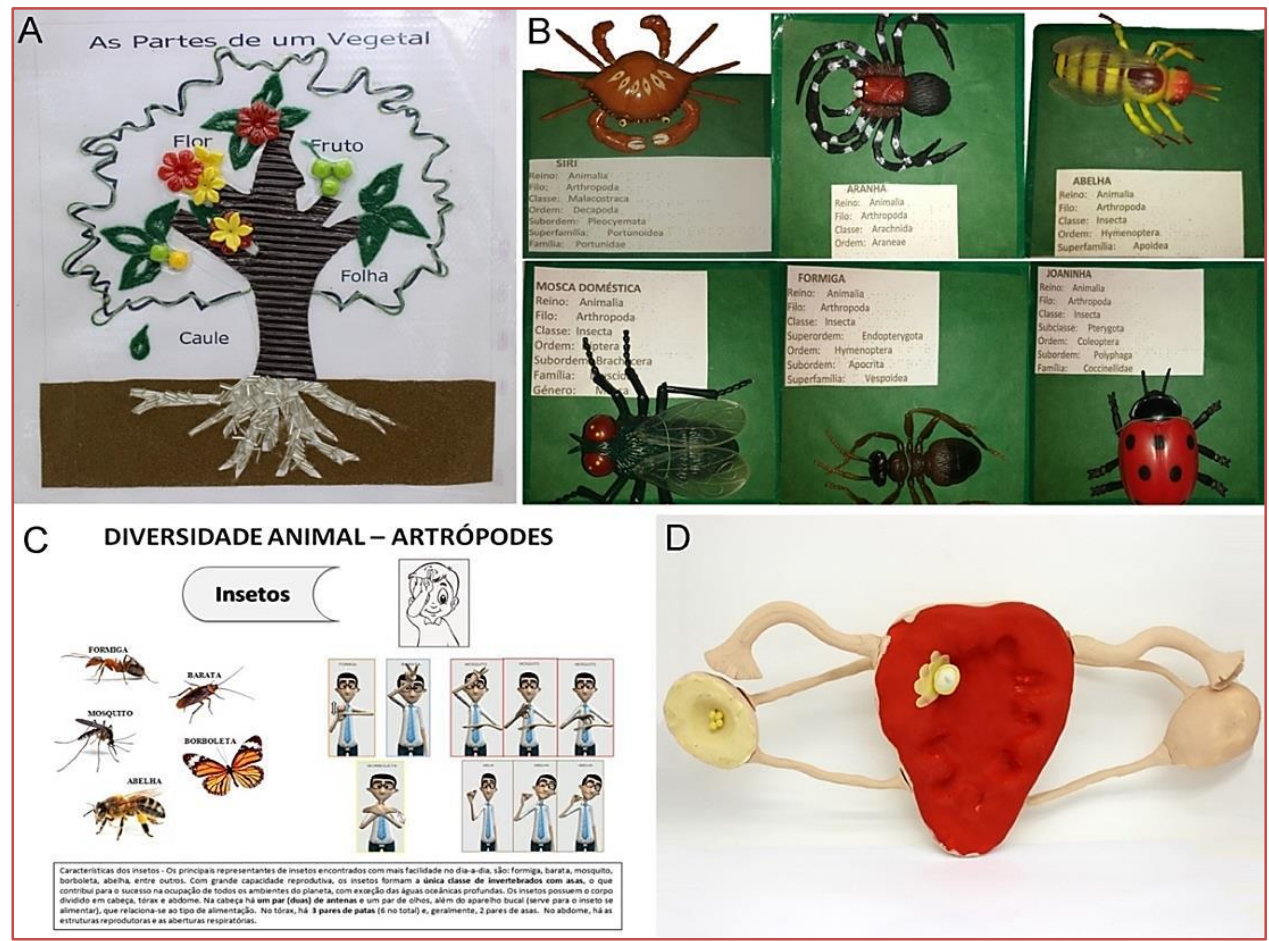

LIBRAS; C- Material sobre artrópodes para alunos surdos; Modelo de genitália interna de biscuit. 


\subsection{ESTRATÉGIAS DE ABORDAGEM}

No ensino de Biotecnologia para os estudantes com deficiência visual foram empregadas diferentes abordagens para melhor compreensão do tema, tentando ao máximo aproximar os métodos e recursos às necessidades destes. Diante disso, esta aula foi dividida em três etapas: vídeo com especialistas na área de Biotecnologia, discussão dos assuntos abordados no vídeo e análise tátil de diferentes modelos didáticos, que propiciaram a imaginação dos objetos utilizados no campo da biotecnologia (Figura 2A). Estes modelos foram de fundamental importância para compreensão e reflexão daquilo que foi ensinado. Adicionalmente, na rotina de aprendizagem com estes alunos outras práticas foram desenvolvidas e estimuladas, como por exemplo: réplicas de peças de arte, textos em braile, mapas em relevo, informações gravadas em $\mathrm{mp} 3$, réplicas de animais e plantas, dentre outros.

No ensino de Biologia com alunos surdos foi utilizada a metodologia que melhor contribuiu para a compreensão destes. Em grande parte dos encontros foi utilizada a língua de sinais como forma de comunicação associado aos conteúdos imagéticos e esquemáticos que contribuem para o entendimento dos alunos surdos. Neste caso, livros e apostilas com muitos textos não são instrumentos adequados uma vez que a língua portuguesa pode ser caracterizada como segunda língua (L2) para a comunidade surda (Figura 2B).

Neste caso, vale ressaltar que a Língua Brasileira de Sinais - LIBRAS foi inserida como disciplina obrigatória nos cursos de licenciatura a partir do a partir do Decreto no. 5.626, de 22 de dezembro de 2005. Desta forma, segundo Santos (2015, p. 108), "[...] a obrigatoriedade de [LIBRAS] um componente curricular em cursos de formação de professores pode configurar-se em um espaço/tempo de possibilidades de desconstruções de ideologias opressoras homogeneizadas". Contudo, para além de propiciar uma comunicação com o aluno surdo, é fundamental que haja preocupação com o processo de ensino-aprendizagem desses estudantes (ROCHA-OLIVEIRA; DIAS; SIQUEIRA, 2019).

0 aluno com deficiência intelectual precisa desenvolver a habilidade de prestar atenção com estratégias diferenciadas, para que depois, este possa compreender o conteúdo ensinado. São três as principais dificuldades enfrentadas por estes alunos: (1) falta de concentração, (2) entraves na comunicação e na interação, e (3) menor capacidade para entender a lógica de funcionamento das línguas, por não compreender a representação escrita ou necessitar de um sistema de aprendizado diferente (FLETCHER et al., 2009; BRASIL, 2010; CASTRO; ALMEIDA; FERREIRA, 2010). Por isso, durante os encontros procuramos desenvolver atividades que estimulassem a concentração, a interação e a capacidade cognitiva, partindo do princípio que estas ações tivessem um início prático e instrumentalizado (Figura 2C).

Para tal, faz-se necessário o emprego de estratégias diferenciadas tanto pelo licenciando/mediador, como pelo professor regente, o qual deve procurar diversificar os modos de exposição durante as aulas, relacionando os conteúdos curriculares a situações do cotidiano, apresentando exemplos concretos para ilustrar ideias mais complexas. Além disso, para o sucesso do processo de aprendizagem é importante adequar a proposta metodológica à idade dos discentes, considerando suas particularidades.

Figura 2 - Estratégias de abordagem para alunos com deficiência visual (A), auditiva (B) e intelectual (C).

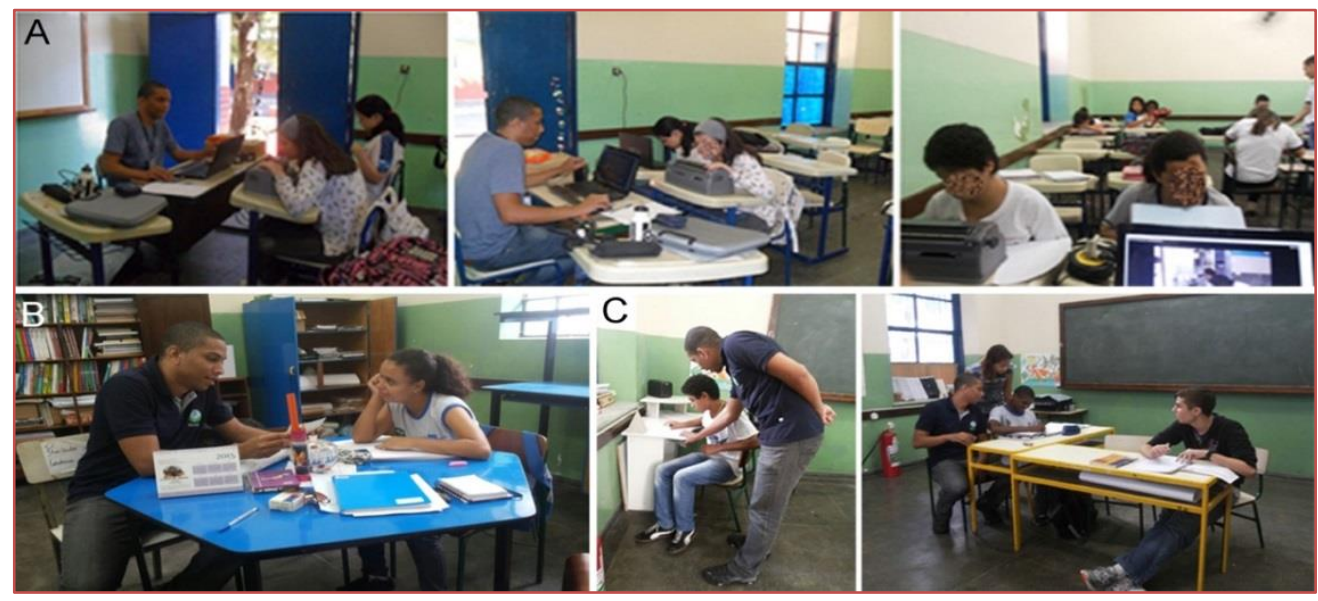


A deficiência intelectual apresenta inúmeras concepções desde a perspectiva histórico-cultural ao modelo médico de caracterização da deficiência. Neste contexto, concorda-se que:

Comparada às deficiências motoras, sensoriais e de comunicação, a deficiência intelectual encontra-se em situação peculiar, tanto devido à invisibilidade inerente ao indivíduo não sindrômico, como pelas representações sociais dominantes que, ao passo que atribuem à pessoa com deficiência intelectual uma cognição infantil, contribuem para lhes excluir do direito a uma vida adulta autônoma e cidadã (DIAS e LOPES DE OLIVEIRA, 2013, p. 170).

No Brasil, a utilização do QI como critério para o diagnóstico desses indivíduos é criticada pelo Ministério da Educação quando este afirma que a deficiência "não se esclarece por uma causa orgânica, nem tão pouco pela inteligência, sua quantidade, supostas categorias e tipos" (BRASIL, 2006, p. 10). Desta forma, é de suma importância considerar não apenas o diagnóstico, mas suas singularidades, formas de socialização e de relação com a aprendizagem. De acordo com Oliveira (2009):

A educação na área da deficiência intelectual deve atender às suas necessidades educacionais especiais sem se desviar dos princípios básicos da educação proposta às demais pessoas, assim sendo, os princípios inclusivistas apontam que elas devem frequentar desde cedo a escola, a qual deve valorizar, sobretudo os acertos da criança, trabalhando sobre suas potencialidades para vencer as dificuldades (OLIVEIRA, 2009, p. 73-74).

Deste modo, é importante destacar que a proposta deste trabalho não foi realizar uma discussão da política a respeito da viabilização da inclusão, mas sim mostrar o que tem sido feito para melhorar a vida escolar dos alunos do colégio em estudo. Assim, acreditamos em uma inclusão que vai além da inserção de alunos com deficiência em classes regulares, mas que conceba a inclusão enquanto um processo que depende de planejamento e capacitação dos segmentos que compõem a comunidade escolar.

Neste sentido, acredita-se que a possibilidade de refletir criticamente sobre si mesmo e sobre o outro deveria ser estimulada desde a primeira infância. Todavia, para que isso ocorra, faz-se necessário pensar sobre os significados da formação na contemporaneidade: como formação interfere na constituição de valores? Em que medida a formação se encontra comprometida com a "emancipação dos homens"? Como se justificam as desigualdades sociais em sociedades que já produziram conhecimentos e tecnologias suficientes para superá-las? Qual é o papel de uma formação que convive com a injustiça social e, paralelamente, não admite a manifestação das diferenças pertinentes à diversidade humana?

Para incentivar permanentemente o desenvolvimento de valores humanos pautados na justiça social, na solidariedade, na paz, na cooperação e na ética, a formação precisa urgentemente se contrapor ao modelo social que a produz. Esses questionamentos evidenciam como estamos distantes de uma verdadeira formação e denunciam a necessidade urgente de uma formação que nos estimule, ao máximo, a estranhar e, principalmente, nos indignar diante das condições que dificultam a equidade no aprendizado e, consequentemente, inviabiliza a inclusão educacional (LIMA e SILVA, 2018).

\section{CONSIDERAÇõES FINAIS}

Estudar a temática da inclusão de alunos com deficiência na prática da educação é introduzir-se em um espaço que ainda dá os seus primeiros passos rumo à qualificação nesse processo. Descrevemos assim, porque já percebemos compreensões de sensibilidade em relação ao tema da inclusão, bem como já são manifestadas experiências que permitem aos professores pensarem nessa perspectiva. As experiências relacionais destacam uma boa relação no âmbito escolar, a qual se amparada em esforços dos professores para possibilitar aos alunos sua participação nas aulas. Entretanto, destaca-se neste processo, o fato dos professores atuarem com base em experiências pessoais ou aplicando seus conhecimentos prévios acerca das necessidades especiais. Deste modo, observa-se que tanto a formação inicial como a formação continuada dos professores não se ocupa de estudos sistemáticos acerca da prática pedagógica da educação que inclui alunos com deficiência.

Neste sentido, assim como os demais profissionais do ensino, a maior dificuldade de um professor de Biologia em trabalhar com alunos com deficiência, é a falta de capacitação especializada, somada à infraestrutura precária das escolas públicas, a escassez de materiais didáticos, além da escassez de 
métodos adequados de avaliação dos estudantes com uma ou múltiplas deficiências. Assim, a inclusão não deve ser vista como um simples acontecimento, mas como um processo, que necessita ser constantemente analisado e avaliado durante o seu desenvolvimento, com responsabilidade e compromisso de todas as esferas da sociedade.

Neste contexto, desejamos refletir à luz do referencial teórico de Vygotsky (1997), que ensina que antes de buscarmos saber quais especificidades a criança possui, é necessário saber que criança possui especificidades. É a partir dessa compreensão que podemos destacar que a escola é o ambiente que pode favorecer possibilidades para a criança, independentemente de suas limitações biológicas.

Romper com essas representações, discutir as questões relativas à função social da escola e à importância de seu trabalho, considerar a diversidade e a heterogeneidade dos alunos e a complexidade da prática pedagógica são dimensões essenciais a serem garantidas na formação do professor. Importa, neste momento histórico de educação para todos, que a formação seja de um professor comprometido com a sua função social de educar igualmente todos os alunos. Por isso, cada experiência vivida dentro dessa perspectiva por um aluno de iniciação à docência, significa um preparo para aquilo que vos espera, pois, a conquista de uma inclusão educacional digna exige a luta permanente por uma formação capaz de se contrapor, ao máximo, às determinações psíquicas e sociais que impedem e/ou limitam a manifestação das diferenças presentes na diversidade humana. Senão, estaremos condenados a cair na trama da inclusão idealizada, que insiste em ameaçar as possibilidades de existência dos valores humanos e/ou inclusivos.

\section{REFERÊNCIAS}

[1] BERTALLI, J. G. Ensino de geometria molecular, para alunos com e sem deficiência visual, por meio de modelo atômico alternativo. 2010. Dissertação (Mestrado em Ensino de Ciências) - Centro de Ciências Exatas e Tecnologia, Universidade Federal do Mato Grosso do Sul. Campo Grande, 2010.

[2] BRASIL. Educação inclusiva: atendimento educacional especializado para a deficiência mental. 2. ed. Brasília, DF: MEC, SEESP, 2006.

[3] Lei no 13.146, de 6 de julho de 2015. Institui a Lei Brasileira de Inclusão da Pessoa com Deficiência. Brasília, 2015. Disponível em: http://www.planalto.gov.br/cci-vil_03/_ato2015-2018/2015/Lei/L13146.htm. Acesso em: Jun. 2018.

[4] _ Ministério da Educação. Secretaria de Educação Especial. A educação especial na perspectiva da inclusão escolar: o atendimento educacional especializado para alunos com deficiência intelectual. Elaboração de Adriana L. Lima Verde Gomes, Jean-Robert Poulin e Rita Vieira de Figueiredo. Brasília: MEC/SEESP; Fortaleza: UFCE, 2010

[5] _ _ Política Nacional de Educação Especial na Perspectiva da Educação Inclusiva. Brasília: Ministério da Educação, Secretaria de Educação $2008 . \quad$ Especial, 2015 . <http://portal.mec.gov.br/arquivos/pdf/politicaeducespecial.pdf>. Acesso em: Jun. 2015.

[6] BREITENBACH, F. V.; HONNEF, C.; COSTAS, F.A.T. Educação inclusiva: as implicações das traduções e das interpretações da Declaração de Salamanca no Brasil. Ensaio: Avaliação e Políticas Públicas em Educação, Rio de Janeiro. [online] v. 24, n. 90, p. 359-379, 2016.

[7] BUENO, J. G. S. A política de inclusão escolar: uma prerrogativa da educação especial? In: BUENO, J. G. S.; MENDES, G. M. L.; SANTOS, R. A. (Orgs). Deficiência e escolarização: novas perspectivas de análises. Araraquara: Junqueira \& Marin; Brasília: CAPES, 2008. p. 43-63.

[8] CARNEIRO, R. U. C.; UEHARA, F. A inclusão de alunos público alvo da educação especial no ensino fundamental I através do olhar dos professores. Revista Ibero-Americana de Estudos em Educação, v. 11, n. esp. 2, p. 911-934, 2016.

[9] CASTRO, J. C. V.; ALMEIDA, M. J. M.; FERREIRA, V. Q. Os benefícios das intervenções pedagógicas para o desenvolvimento cognitivo do estudante com déficit intelectual. In: Anais das Jornadas de Pós-Graduação da Faculdade Integrada Brasil Amazônia - FIBRA, Belém, n. 3, p. 21-33, set. 2010.

[10] CROCHÍK, J. L. Educação inclusiva, subjetividade, preconceito e direitos humanos: qual sua relação? In: SILVA, A. M. M.; COSTA, V. A. (Orgs.). Educação inclusiva e direitos humanos: perspectivas contemporâneas. São Paulo: Cortez, 2015, p. 23-53.

[11] DIAS, S. S.; LOPES DE OLIVEIRA, M. C. S. Deficiência Intelectual na Perspectiva Histórico-Cultural: Contribuições ao Estudo do Desenvolvimento Adulto. Revista Brasileira de Educação Especial, v. 19, n. 2, p. 169-182, 2013. 
[12] FERREIRA, W. B. 20 anos depois de Salamanca... onde estamos e para onde vamos? Poíesis Pedagógica, v. 13, n. 1, p. 87-106, 2015.

[13] FLETCHER, J. M.; LYONS, G. R.; FUCHS, L. S.; BARNES, M. A. Transtornos de aprendizagem. Porto Alegre: Artmed, 2009.

[14] FONSECA-JANES, C. R. X. A formação de estudantes de pedagogia para a educação inclusiva: estudo das atividades sociais e do currículo. (Tese de Doutorado em Educação). Programa de Pós-Graduação em Educação, Universidade Estadual Paulista, Marília. 2010.

[15] FREIRE, P. Pedagogia da Autonomia: saberes necessários à prática educativa. São Paulo: Paz e Terra, 1996.

[16] GONÇALVES, F. P.; REGIANI, A. M.; AURAS, S. R.; SILVEIRA, T. S.; COELHO, J. C.; HOBMEIR, A. K. T. A educação inclusiva na formação de professores e no ensino de Química: a deficiência visual em debate. Química Nova na Escola, v. 35 , n. 4 , p. 264-271, 2013.

[17] LIMA, M.C.; SILVA, D. G. A formação inicial de professores em Ciências Biológicas na perspectiva da Educação Inclusiva: uma análise da literatura. Revista Diálogos e Perspectivas em Educação Especial, v. 5, n.1, p. 67-82, 2018.

[18] MANTOAN, M. T. E. Ensino Inclusivo/Educação (de qualidade) para todos. In. Revista Integração, Ministério da Educação e do Desporto, SEESP, ano 8, n. 20. p. 30-32, 1998.

[19] MATOS, C.; OLIVEIRA, C. R. F.; SANTOS, M. P. F.; FERRAZ, C. S. Utilização de modelos didáticos no ensino de entomologia. Revista de Biologia e Ciências da Terra, v. 9, n. 1, p. 19-23, 2009.

[20] MINAYO, M. C. S. O desafio da pesquisa social. In M. C. S. Minayo (Org.), Pesquisa social: teoria, método e criatividade (pp. 9-29). Petrópolis, RJ: Vozes. 2012.

[21] NERI, M.; PINTO, A.; SOARES, W.; COSTILLA H. Retratos de deficiência no Brasil (PPD). Fundação Banco do Brasil. Rio de Janeiro: FGV/IBRE, CPS, 2003. p. 81.

[22] NUNES, S.; LOMÔNACO, J. F. B. 0 aluno cego: preconceitos e potencialidades. Revista Semestral da Associação Brasileira de Psicologia Escolar e Educacional, v. 14, n. 1, p. 55-64, 2010.

[23] OLIVEIRA, A.A. A célula ao alcance das mãos: construindo modelos didáticos para o ensino de citologia para deficientes visuais. 2014. 100f. Monografia (Graduação em Ciências Biológicas). Centro Universitário Norte do Espirito Santo, Universidade Federal do Espirito Santo, São Mateus, 2014.

[24] OLIVEIRA, A. A. S. Estratégias para o ensino inclusivo na área da deficiência intelectual: alguns apontamentos. In: MARQUEZINE, M.C.; MANZINI, E.J.; BUSTO, R.M.; TANAKA, E.D.O.; FUJISAWA, D.S. (Org.). Políticas públicas de formação de recursos humanos em educação especial. Londrina: ABPEE, p. 69-82, 2009.

[25] OLIVEIRA, F. I. W.; BIZ, V. A.; FREIRE, M. Processo de inclusão de alunos deficientes visuais na rede regular de ensino: Confecção e utilização de recursos didáticos adaptados. Marília, SP: Unesp, 2002. Disponível em: <http://www.unesp.br/prograd/PDFNE2003/Processo\%20de\%20inclusao\%20de\%20alunos\%20deficientes\%20vis uais.pdf $>$. Acesso em: Jun. 2016.

[26] OLIVEIRA, M. L.; ANTUNES, A. M.; ROCHA, T. L.; TEIXEIRA, S. M. Educação inclusiva e a formação de professores de ciências: o papel das universidades federais na capacitação de futuros educadores. Revista Ensaio, v. 13, n. 3, p. 99-117, 2011.

[27] PEDROSO, C. C. A.; CAMPOS, J. A. P. P.; DUARTE, M. Formação de professores e educação inclusiva: análise das matrizes curriculares dos cursos de licenciatura. Educação Unisinos, v. 17, n. 1, p. 40-47, 2013.

[28] PEREIRA, A. R.; PEREIRA, M. R.; VIRGENS, K. L.; RIBEIRO, S. D. Formação dos professores de ciências naturais: reflexões sobre inclusão escolar. Brazilian Applied Science Review, v. 2, n. 2, p. 697-711, 2018.

[29] PICCOLO, G. M. As bases do processo de formação docente voltado à inclusão. Revista Educação Especial, v. 22, n. 35, p. 363-374, 2009.

[30] PIETRO, R. G. Atendimento escolar de alunos com necessidades educacionais especiais: um olhar sobre as políticas públicas de educação no Brasil. In: MANTOAN, T. E.; PIETRO, R. G.; ARANTES, V. A. (Org.). Inclusão escolar: pontos e contrapontos. São Paulo: Summus, 2006. p. 31-69.

[31] PIMENTEL, S. C. Adaptações curriculares com deficiência intelectual na escola regular: proposta para inclusão ou para segregação? Cadernos de Educação, n. 45, p. 44-50, 2013.

[32] PLETSCH, M. D. Educação especial e inclusão escolar: políticas, práticas curriculares e processos de ensino e aprendizagem. Poíesis Pedagógica, v. 12, n. 1, p. 7-26, 2014.

[33] REIS, S. E.; SILVA, P. L. O ensino das ciências naturais para alunos surdos: concepções e dificuldades dos professores da escola Aloysio Chaves. Revista do EDICC (Encontro de Divulgação de Ciência e Cultura), v. 1, 2012. 
[34] ROCHA-OLIVEIRA, R.; DIAS, V. B.; SIQUEIRA, M. Formação de Professores de Biologia e Educação Inclusiva: Indícios do Projeto Acadêmico Curricular. Revista Brasileira de Pesquisa em Educação em Ciências, v. 19, p. 225-250, 2019.

[35] ROCHA-OLIVEIRA, R.; MACHADO, M. S.; SIQUEIRA, M. Formamos professores para a educação inclusiva? Análise de publicações sobre formação de professores de Ciências/ Biologia. Revista Brasileira de Ensino de Ciência e Tecnologia, v. 10, n. 2, p. 1-23, 2017.

[36] SANTOS, E. F. O ensino de libras na formação do professor: um estudo de caso nas licenciaturas da Universidade Estadual de Feira de Santana. (Dissertação de Mestrado em Educação). Programa de Pós-Graduação em Educação, UEFS, Feira de Santana. 2015.

[37] SANTOS, M. L. O. Inclusão escolar e a formação de professores de ciências da natureza. Trabalho de conclusão de curso de Licenciatura em Ciências Biológicas (Monografia), Universidade Federal da Fronteira Sul, campus Cerro Largo - RS. 2018, 43f.

[38] SCHIMIDT, A. Metacontingências na escola inclusiva. Resumos do X Encontro Brasileiro de Psicoterapia e Medicina Comportamental, p. 165, 2001.

[39] UNESCO. Declaração de Salamanca: sobre princípios, políticas e práticas na área das necessidades educativas. Especiais. Brasília, DF: Ministério da Educação. 1994.

[40] VAZ, J. M. C.; PAULINO, A. L. S.; BAZON, F. V. M.; KIILL, K. B.; ORLANDO, T. C.; REIS, M. X.; MELLO, C. Material Didático para Ensino de Biologia: Possibilidades de Inclusão. Revista Brasileira de Pesquisa em Educação em Ciências, v. 12, n. 3, 2012.

[41] VERASZTO, E. V.; VICENTE, N. E. F. Desenvolvimento de atividades de ensino de citologia para alunos com deficiências visuais: ações de educação inclusiva a partir da Teoria dos Contextos Comunicacionais. Revista de Estudos Aplicados em Educação, v. 2, n. 4, 2017.

[42] VYGOTSKY, L.S. Obras escogidas: fundamentos de defectología. Tomo V. Madrid: Visor, 1997. 


\section{Capítulo 12}

\section{Alfabetização científica na formação de professores: Indicadores do processo em registros escritos de licenciandos em biologia}

\section{Karla Jeane Coqueiro Bezerra Soares \\ Mariana Guelero do Valle}

Resumo: 0 processo de Alfabetização Científica (AC) vem ganhando grandes destaques, pois permite que cada indivíduo disponha de informações para que possa dialogar e argumentar acerca de temas que ultrapassam o senso comum. Concomitantemente, pretende-se que o ensino de Ciências/Biologia assuma uma forma mais crítica, e embora se reconheça o papel dos demais componentes no processo de ensino-aprendizagem, cabe ao professor grande parte dessa responsabilidade. Assim, este trabalho tem como objetivo principal investigar a presença da AC em um curso de formação de professores de biologia, através da identificação de indicadores desse processo presentes nos discursos escritos de licenciados. Os sujeitos desta pesquisa são alunos matriculados no estágio supervisionado I e II e cursavam períodos finais do curso. Nossas coletas se deram por meio de um questionário com perguntas adaptadas do ENEM. Por meio dos dados obtidos obtivemos evidências da presença do processo de AC nos alunos em questão, bem como identificamos aspectos importantes de como diferentes alunos mobilizam algumas competências próprias das ciências e do fazer científico. Portanto, acreditamos que a formação de professores de ciências/biologia da educação básica para uma prática docente voltada a AC, também precisa ter uma formação sob essa perspectiva, e este trabalho nos permitiu inferir que o curso de Ciências Biológicas da UFMA está criando tais oportunidades.

Palavras-chave: Alfabetização científica, formação de professores, ensino de ciências e biologia. 


\section{INTRODUÇÃO}

O processo de Alfabetização Científica é um campo no qual vamos encontrar a existência de diferentes concepções e orientações, abrangendo um espectro amplo de significados. Assim, conceber uma significação para Alfabetização Científica, também implica reconhecer a polissemia que envolve o próprio termo alfabetizar. Por sugestão da Organização das Nações Unidas para a Educação, a Ciência e a Cultura o termo alfabetizar ganha um sentido bem amplo e define como alfabetizado aquele que tem a "Capacidade de identificar, compreender, interpretar, criar, comunicar, calcular e utilizar materiais impressos e escritos relacionados com contextos variados" (2011, p. 297). Da mesma forma, Paulo Freire também considera que alfabetizar não seria sinônimo de "ler" e "escrever" apenas "É o domínio destas técnicas em termos conscientes. [...] Implica numa autoformação de que possa resultar uma postura interferente do homem sobre seu contexto". (FREIRE, 2011, p.111)

Assim, neste trabalho se utilizará o termo "Alfabetização Científica" apoiado pela visão de Paulo Freire (2005, p.19), no qual considera que a "alfabetização não é um jogo de palavras; é a consciência reflexiva da cultura, a reconstrução crítica do mundo humano, a abertura de novos caminhos". Nesse contexto, ser alfabetizado cientificamente significa ser capaz de realizar uma leitura do mundo ao nosso redor, além de permitir ao indivíduo a compreensão de conhecimentos, procedimentos e valores que o tornam crítico em relação ao desenvolvimento e às múltiplas aplicações da ciência (CHASSOT, 2003).

Krasilchik e Marandino (2011, p. 26) comentam que a alfabetização científica é a "capacidade de ler, compreender e expressar opiniões sobre ciência e tecnologia", enquanto Furió et al. (2001) explicam que $\mathrm{AC}$ é a forma pela qual a população toma consciência das relações entre ciência e sociedade e utiliza-se desses conhecimentos como suporte na sua vida, por exemplo, ajudando a resolver os problemas e as necessidades de saúde e sobrevivência básica. Segundo Sasseron e Carvalho (2011) o que se observa é que, embora haja vários questionamentos acerca da significação da AC nota-se que o âmago destas discussões vigora muitas vezes por um mesmo objetivo: preparar os alunos para a vida em sociedade, levando em conta sua atuação cidadã, crítica e responsável. Assim, a AC é importante, pois dá consistência e fundamentação aos conhecimentos de cada um e permite que cada indivíduo disponha de informações sólidas para que possam dialogar e argumentar acerca de temas que ultrapassam o senso comum

Portanto, no que tange à clientela à qual a $\mathrm{AC}$ está destinada, ainda que muitos autores (SANTOS; MORTIMER, 2001; LORENZETTI E DELIZOICOV 2001; SASSERON; CARVALHO, 2008; TRAJANO, 2011) enfatizem sua importância nas séries iniciais para que desde cedo à criança desenvolva conceitos e adquira conhecimentos relacionados aos fenômenos que acerca, os mesmos explicam que somente os anos iniciais frequentados pelos alunos não são suficientes para a Alfabetização Científica integralmente, pois a Ciência não pode ser vista como algo estático, ela é dinâmica e o próprio processo de amadurecimento humano, assim como seus objetivos, requer tempo. Desse modo, o público-alvo a que se destina a Alfabetização Científica, percorre desde as crianças nas séries iniciais (ensino fundamental I e II), inclui também aqueles que se encontram no ensino médio, educação de jovens e adultos, ensino técnico, ensino superior e até mesmo professores.

Assim, no que tange a formação docente, este contexto particular de ensino ganha um importante papel, no qual não pode ser vista apenas em sua extensão técnica e centrada na perspectiva da instituição formadora, mas deve estar pautado numa visão holística formando pessoas autônomas, que extrapolem a visão historicamente técnica do ensino e visem à formação integral do ser humano. Candau (2010), afirma que, a formação de professores, no modelo tradicional, separada da realidade cultural, social e política, transforma o professor em um reprodutor de conteúdos e desse modo, a formação inicial deste futuro professor precisa prover um profissional não somente de conhecimentos científicos, mas também de criticidade, habilidades e atitude reflexiva sobre sua prática ou a prática que vai exercer.

Desse mesmo modo, contemporaneamente pretende-se que o ensino de Ciências/Biologia também assuma uma forma mais crítica, procurando formar cidadãos conscientes de seu papel social e político, capazes de falar e usar as ciências. E embora se reconheça o papel dos demais componentes humanos no processo de ensino-aprendizagem, cabe ao professor grande parte dessa responsabilidade. Em suma, a formação de professores críticos e reflexivos, de profissionais engajados e capacitados para promover AC é desafio emergente e imprescindível em qualquer tentativa consequente de transformação da escola.

A partir dessa visão, faz necessário voltarmos nossos olhares para a formação dos professores, que serão mediadores deste processo de $\mathrm{AC}$ na educação básica, que precisam ter uma formação inicial também baseada na perspectiva da $\mathrm{AC}$ para que, os futuros professores não sejam apenas reprodutores de currículos. 
Dessa forma, neste capítulo abordaremos uma pesquisa apresentada no I Congresso Nacional de Pesquisa e Ensino de Ciências cujo objetivo foi investigar o processo de Alfabetização Científica em um contexto particular de formação de professores: o curso de Ciências Biológicas, da Universidade Federal do Maranhão (UFMA), campus Dom Delgado- São luís, por meio da identificação de indicadores nos discursos escritos de licenciados pertencentes ao estágio final do curso em questão.

\section{PROCEDIMENTOS METODOLÓGICOS}

A presente pesquisa é de natureza qualitativa, na qual foram avaliadas as produções escritas de alunos que estavam inscritos no componente curricular Estágio Licenciatura I e II no $2^{\circ}$ semestres de 2014 e, a qual contava com um total de 16 alunos do estágio I, referente ao ensino fundamental e 02 alunos do estágio II, referente ao ensino médio. A fim de preservar o anonimato dos participantes, foram usados códigos para referirmos aos alunos: a letra E seguida de um número, como E1, E2, E3, representarão estes estudantes.

Optamos por estes sujeitos por acreditarmos que o Estágio Supervisionado é um momento importante e fundamental para oportunizar ao estagiário a possibilidade da imersão no contexto escolar. As atividades realizadas durante os estágios, como as observações dos intervalos, das aulas, das reuniões, bem como, as regências e participação em outras atividades do ambiente escolar, oportunizam ao licenciando elaborar e internalizar ações pedagógicas, incluindo aquelas relacionadas ao processo de AC.

A situação investigada refere-se à análise de produções escritas obtidas a partir de um questionário, em que os alunos responderam questões de conhecimentos gerais e específicos do programa avaliativo "Exame Nacional do Ensino Médio" (ENEM). Entendemos, que o ENEM embora seja um exame destinado aos alunos do ensino médio, apresentam questões contextualizadas, que priorizam eixos cognitivos como enfrentar situações-problema, dominar linguagens, compreender fenômenos, construir argumentação, e dessa forma, espera-se que os professores em formação estejam preparados para responder questões dessas naturezas. 0 questionário trazia 04 perguntas correspondentes às provas de 2009, 2011, 2012 e 2013, entretanto, foi necessário realizar algumas adaptações com o objetivo de transformar as questões objetivas em discursivas de modo a obter dados suficientes para análise dos indicadores.

Assim, para análise dos dados foi utilizado como referencial teórico-metodológico os indicadores de alfabetização científica propostos por Sasseron e Carvalho $(2008,2011)$. Os indicadores estão divididos em três grupos. 0 primeiro relaciona-se especificamente às ações desempenhadas nas tarefas de seriação, organização e classificação de informações dos dados obtidos em uma investigação. No segundo grupo estão os indicadores relacionados ao entendimento do sujeito para situação analisada. Fazem parte desse grupo o levantamento e teste de hipóteses para a situação analisada; a justificativa e a explicação que fundamentam as ideias propostas; e a previsão de uma ação que pode ocorrer. E por fim, no terceiro grupo, estão os indicadores que estruturam e organizam as ideias construídas e apresentadas, sendo eles o raciocínio Lógico, que demonstram a coerência interna na estruturação das ideias seja falada ou escrita; e o raciocínio Proporcional, que permite demonstrar uma possível relação de proporcionalidades e de possível interdependência entre as variáveis envolvidas no problema.

Em suma, ainda que esta ferramenta de análise tenha sido proposta incialmente para outra modalidade de ensino, sendo este o ensino fundamental, tais indicadores representam, ações e habilidades desempenhadas nas construções mentais que levaram a resolução de um problema investigado durante o processo da AC. Portanto, acreditamos que buscar estes indicadores nos discursos escritos dos licenciandos pode fornecer evidencias fortes de que esses futuros professores também estão imersos no processo de AC.

\section{RESULTADOS E DISCUSSÃO}

Para esta análise foram usadas as respostas completas dos sujeitos, transcritas tal como foram elaboradas, e, portanto, erros ortográficos não foram corrigidos. Embora o questionário apresente quatro perguntas, aqui faremos um recorte selecionando dois exemplos bem representativos de respostas da questão 1 e 2 , no qual respectivamente, abordam um tema específico da área de biologia, sendo este genética e biologia molecular, e a outra aborda uma questão de caráter geral, que envolve aspectos relativos a biologia, geografia, entre outros.

\section{Questão 01}


A questão abordou o tema referente à engenharia genética e permitiu que os alunos além de demonstrarem conhecimento sobre o assunto, possam fornecer explicações na qual percebam os fatores éticos e políticos que envolvem o problema da questão. 0 enunciado traz um texto explicando a criação da "célula sintética". Ao final faz seguinte pergunta: "Qual (quais) a(s) importância(s) dessa inovação tecnológica tanto para a comunidade científica como para toda a sociedade? EXPLIQUE"

O sujeito E8 respondeu:

"Penso que a mais importante vantagem dessa técnica com células seria se conseguíssemos fazer a produção de substâncias obtidas a partir de organismos difíceis de serem cultivados. Recentemente, houve uma palestra aqui na UFMA de um professor alemão que afirmou que mais de $90 \%$ dos organismos microbianos não eram cultiváveis. Logo, conhecendo o gene que produz tal substância (mais maquinaria associada) seremos capazes de manipular organismos cultiváveis a produzir substâncias de organismos não cultiváveis". (E8)

Notamos que ele inicia levantando uma hipótese do que poderia ser feito com essas células sintéticas: "Penso que a mais importante vantagem dessa técnica com células seria se conseguíssemos fazer a produção de substâncias obtidas a partir de organismos difíceis de serem cultivados”. Em seguida o sujeito traz uma informação nova que advém de uma palestra que assistiu. Percebe-se que essa informação nova foi proferida no sentindo de organizar a informação que será utilizada posteriormente: "Recentemente, houve uma palestra aqui na UFMA de um professor alemão que afirmou que mais de $90 \%$ dos organismos microbianos não eram cultiváveis". Assim o sujeito finaliza sua resposta mostrando a relação entre uma hipótese e as informações que adquiriu na palestra assistida, fazendo uso então de explicação para fechar o seu pensamento: "Logo, conhecendo o gene que produz tal substância (mais maquinaria associada) seremos capazes de manipular organismos cultiváveis a produzir substâncias de organismos não cultiváveis". Junto à sua explicação podemos notar também uma previsão: "seremos capazes de manipular organismos cultiváveis a produzir substâncias de organismos não cultiváveis". Percebemos que o sujeito fez uso do raciocínio lógico na estrutura interna na sua explicação. Percebemos assim que a resposta do sujeito em sua totalidade é uma explicação bem construída, que apresenta início, meio e fim bem definidos e estruturado coerentemente.

O indivíduo E11 respondeu:

“A vista de coisas possíveis para produzirmos através de bactérias sintéticas é quase infinita: produção de drogas ou outras substâncias funcionais, tal como combustíveis, alimentos, destruição de materiais não decompostos ou decompostos vagarosamente, como plástico, assim como utilizadas para guerra biológica, destruição da CO2 na atmosfera. " (E11).

O sujeito E11 começa fazendo uma afirmação com o sentido de organizar informação para as próximas observações feitas: "A vista de coisas possíveis para produzirmos através de bactérias sintéticas é quase infinita". Em seguida o sujeito continua fazendo uma lista de todas as possibilidades com a produção da referida célula sintética: fazendo então uma seriação de informação: "produção de drogas ou outras substâncias funcionais, tal como combustíveis, alimentos, destruição de materiais não decompostos ou decompostos vagarosamente, como plástico, assim como utilizadas para guerra biológica, destruição da CO2 na atmosfera".

Nessa questão conseguimos notar nas respostas dos sujeitos que os indicadores apareceram de forma variada. Tiveram respostas em que o sujeito usou poucos indicadores, com organização e seriação de informação ao elencar uma série de possíveis usos para a célula sintética, como podemos notar. Às vezes apareceram como levantamento de hipótese, e assim consideramos quando o sujeito apresentou suas respostas utilizando de verbos como "poderia", "pode vir a ser", "seria". E outras vezes apareceram como uma previsão, quando o aluno afirmou uma ação. Percebemos também que nesta turma houve muitas respostas que continham o raciocínio lógico, utilizado para dar uma estrutura coerente a sua explicação. Sendo que foram dez respostas que utilizaram esse indicador.

\section{Questão 02}

0 assunto principal da questão refere-se ao tema geração de energia. Primeiramente contém um enunciado que introduz o tema. Em seguida são apresentadas as perguntas que estão divididas em letra a e b.

\section{Letra a}

Em uma situação hipotética, optou-se por construir uma usina hidrelétrica em região que abrange diversas quedas d'água em rios cercados por mata, alegando-se que causaria impacto ambiental muito 
menor que uma usina termelétrica. Cite pelo menos 02 possíveis impactos da instalação de uma usina hidrelétrica nessa região para justificar que tal empreendimento também terá seus efeitos negativos.

O sujeito E5 apresentou a seguinte ideia:

"Afeta a população de organismos que vivem no local, perturbando o equilíbrio ecológico e desregulando toda a cadeia trófica daquela região, pois partes da mata que cerca as quedas d'água seriam perdidas para construção da hidrelétrica. Isto poderia ter graves consequências, uma vez que, partes dessa vegetação protegem o leito do rio e impendem possíveis enchentes, erosão e soterramento." (E5)

Percebe-se que a resposta do sujeito em sua totalidade foi fornecida para além de citar os impactos, explicar suas consequências e implicações. 0 sujeito E5 faz uso de seriação de informação ao indicar um impacto que ocorre com a instalação da usina: "Afeta a população de organismos que vivem no local". Mas atrelado a isso vem uma série de consequências, e então o sujeito faz uso de previsões associadas ao impacto que elencou: "perturbando o equilíbrio ecológico e desregulando toda a cadeia trófica daquela região"; e usa de uma garantia que forneça aval a sua previsão, usando de justificativa: "pois partes da mata que cerca as quedas d'água seriam perdidas para construção da hidrelétrica". E dessa forma ele finaliza fazendo uma explicação: "Isto poderia ter graves consequências, uma vez que, partes dessa vegetação protegem o leito do rio e impendem possíveis enchentes, erosão e soterramento". Percebemos também que o sujeito faz uso de raciocínio lógico para dar uma estrutura coerente para sua explicação.

O sujeito E9 explica que:

"O primeiro impacto é o impacto local que a construção de usina hidrelétrica gera. A mata ao redor das áreas será desmatada, poluentes serão lançados no rio e estradas serão abertas. 0 segundo impacto é mais abrangente, pois pode significar a mudanças de áreas enormes de mata e esse impacto é extremamente grave por afetar uma quantidade imensurável de organismos e relações ecológicas. " (E9)

O sujeito identifica dois impactos iniciais na instalação de uma usina hidroelétrica. E para tal usa de seriação de informação ao elencar dois impactos: "O primeiro impacto é o impacto local que a construção de usina hidrelétrica gera" e "O segundo impacto é mais abrangente, pois pode significar a mudanças de áreas enormes de mata". E faz várias previsões sobre as consequências causadas por esses dois impactos: "A mata ao redor das áreas será desmatada, poluentes serão lançados no rio e estradas serão abertas" e "esse impacto é extremamente grave por afetar uma quantidade imensurável de organismos e relações ecológicas", respectivamente. Percebemos o cuidado de elencar os impactos e mostrar suas consequências, dessa forma a resposta do sujeito em sua totalidade é uma explicação para o problema. Utilizou-se também de raciocínio lógico na estruturação de sua explicação.

A partir da totalidade das respostas, podemos inferir que existem certas perguntas ou situaçõesproblemas, que condiciona um padrão de aparecimento de determinados indicadores, seja isolado ou acompanhado de outros indicadores. Nesta questão podemos observar que ao solicitar que os indivíduos indicassem dois possíveis impactos e não solicitar que os mesmos fornecessem nenhuma explicação ou justificativa, isso condicionou as respostas dos alunos a usar o indicador seriação de informação com mais frequência, listando os impactos que julgaram poder ocorrer com a implantação de uma usina hidroelétrica. Notamos que das respostas analisadas, três delas o indicador seriação de informação apareceu isolado, seis respostas em que este mesmo indicador estava acompanhado do indicador previsão, uma resposta que além de seriação e previsão continha justificativa e explicação como notado na resposta do sujeito E5, uma resposta continha além de seriação e previsão também o indicador explicação como observado na resposta do aluno E9. Em relação aos indicadores que moldam a estruturação do pensamento, quatro alunos usaram este indicador.

\section{Letra b}

Suponha que você seja um consultor e foi contratado para assessorar a implantação de uma matriz energética em um pequeno país com as seguintes características: região plana, chuvosa e com ventos constantes, dispondo de poucos recursos hídricos e sem reservatórios de combustíveis fósseis. De acordo com as características desse país, aponte a matriz energética de menor impacto e risco ambientais baseada nas características do lugar. Justifique a escolha.

O aluno E8 explicou que:

"Escolheria a energia eólica, devido aos ventos e as chuvas (a solar que seria a melhor, não é uma opção). Mas, é preciso fazer um levantamento faunístico para possível manejo de algumas espécies que podem ser afetas pelas turbinas (ex: morcegos), embora ainda não se saiba ao certo qual seria a influência. " (E8) 
O sujeito classifica uma informação, categorizando o tipo de matriz que escolheria: "Escolheria a energia eólica". E justifica sua escolha: "devido aos ventos e as chuvas". Baseado na sua escolha ele faz uma previsão ao dizer que "a solar que seria a melhor, não é uma opção". E finaliza explicando que mesmo esse tipo de energia tem seus impactos: "Mas, é preciso fazer um levantamento faunístico para possível manejo de algumas espécies que podem ser afetas pelas turbinas (ex: morcegos), embora ainda não se saiba ao certo qual seria a influência". Conseguimos ver também o uso do raciocínio lógico para estruturar sua resposta de forma coerente para leitor.

\section{O sujeito E7 explicou que:}

"Matriz energética de produção de energia eólica já que os poucos recursos hídricos não permite a construção de uma usina hidrelétrica, e o grande número de chuvas prejudicaria uma produção de energia solar." (E7)

Percebemos o uso de classificação de informação: "Matriz energética de produção de energia eólica"; e justifica sua escolha: "já que os poucos recursos hídricos não permite a construção de uma usina hidrelétrica, e o grande número de chuvas prejudicaria uma produção de energia solar". E observamos o uso do raciocínio proporcional na estrutura do seu pensamento, uma vez que além de ter demonstrado que o uso da energia eólica precisa da presença de ventos constantes, mostrou também que para o uso da energia solar não ficaria viável devido as constantes chuvas, e dessa forma demostrando a relação de interdependência que há entre o tipo de matriz e o tipo de ambiente.

Assim como na letra a podemos observar nesta pergunta, que a natureza da questão e o modo em que a pergunta é feita, influencia diretamente no aparecimento de indicadores específicos, mesmo que eles venham acompanhados de outros indicadores. Nesta pergunta, o indicador que apareceu em todas as respostas foi classificação de informação, servindo para categorizar o tipo de matriz energética que poderia ser utilizado no país indicado na situação-problema. Nas respostas, associados a este indicador vieram à justificativa, em maior frequência, explicação ou previsão. Em relação aos indicadores que estruturam as ideias, percebemos o uso do raciocínio lógico em cinco respostas e o raciocínio proporcional apareceu duas vezes. Ressalvamos que o uso do raciocínio proporcional, só foi considerado nas respostas quando o sujeito demostrava que o tipo de matriz estava diretamente relacionado com o tipo de ambiente, demostrando a relação de interdependência entre essas duas variáveis.

\section{CONCLUSÃO}

Acreditamos que a formação de professores de ciências/biologia da educação básica para uma prática docente voltada a Alfabetização Científica, também precisa ter uma formação sob essa perspectiva. Assim consideramos importante investigar se os licenciados de biologia matriculados nos estágios supervisados estavam imersos nesse processo de AC, tendo em vista que se trata do primeiro contato destes com a sala de aula. Por meio dos dados obtidos obtivemos evidências da presença do processo de AC nos alunos em questão, bem como identificamos aspectos importantes de como diferentes alunos mobilizam algumas competências próprias das ciências e do fazer científico.

Em suma, nossos dados revelam, portanto que indicadores estão condicionados a dois aspectos diferentes: 1) o enunciado da pergunta; 2) a natureza da pergunta. Em relação ao enunciado observamos que dependendo dos dados que a pergunta traz, como por exemplo, um texto, uma figura, determinados indicadores podem aparecer e outros não, uma vez que os alunos podem interpretar que explicação já estejam implícitas no texto fornecido e não considerarem necessário expressá-los, enquanto que outros alunos podem se utilizar desses dados para compor suas respostas. No que tange a natureza de pergunta, conseguimos perceber que perguntas "abertas" que solicitam aos sujeitos interpretar ou fornecerem explicações, possibilita que para uma única resposta apareçam diferentes indicadores. Em contraposição, perguntas "fechadas", ou seja, mais objetivas, que não pedem explicações ou justificativas, pode condicionar o aparecimento de diversidade menor de indicadores para uma mesma resposta, e, portanto, diferentes alunos podem elaborar respostas com o uso dos mesmos indicadores.

Por fim, gostaríamos de ressaltar que foi possível identificar, que os alunos conseguiram tecer explicações para além dos conceitos, utilizando de experiências próprias para compor suas explicações ou mostrando a relação que possa haver entre CTSA. Segundo diversos estudiosos (JIMÉNEZ-ALEIXANDRE et al., 2000, FOUREZ, 2003, LEMKE, 2006) um dos objetivos da AC é oportunizar a formação de cidadãos que saibam sobre Ciência e suas tecnologias e consigam compreender as relações e implicações entre essas duas esferas e a sociedade e o ambiente. Assim poder identificar que os alunos forneceram explicações 
contextualizando a partir de relação entre CTSA, nos proporciona indícios importantes de que o processo da AC está ocorrendo no nosso curso.

Contudo, não podemos afirmar que, alunos que deram explicações mais contextualizadas e/ou ainda forneceram respostas com uma quantidade expressiva de indicadores, são mais alfabetizados cientificamente do que os que não teceram explicações nessas perspectivas, pois como já vimos, o enunciado e natureza da pergunta tem influência nas respostas, e consequentemente no aparecimento de menos ou mais indicadores, e as explicações fornecidas podem depender dessas características. Portanto, os indicadores apenas nos fornecem evidências de que o processo de AC está em desenvolvimento e não que um indivíduo seria mais ou menos alfabetizado que outro.

Assim, acreditamos que os cursos de formação precisam promover oportunidades de que esses indicadores e os pressupostos da AC se desenvolvam, seja direta ou indiretamente, tanto na escrita quanto na oralidade, desde os períodos iniciais até os períodos finais, para que esses alunos utilizem dessa alfabetização científica tanto para si, quanto para promover um ensino pautado nessa perspectiva, quando chegar o momento desses alunos exercerem o ofício docente.

É importante ressaltarmos também, que estudos envolvendo o tema alfabetização científica no ensino superior ainda são relativamente escassos na literatura, dos quais a maioria se destina à educação básica. Assim, partindo dessa perspectiva consideramos de suma importância desenvolver um estudo buscando a identificação desse processo nesse contexto de ensino, em especial aqueles referentes à formação de licenciados, pois cabe a esse profissional a escolha de perpetuar um ensino tecnicista ou se aventurar na formação de cidadão críticos reflexivos, capazes de realizar essa leitura do mundo.

\section{REFERÊNCIAS}

[1] CANDAU, V. M. (Org.). Rumo a uma nova didática. 20 ed. Petrópolis: Vozes, 2010.

[2] CHASSOT, A. Alfabetização Científica: uma possibilidade para a inclusão social. Revista Brasileira de Educação, n. 22, p. 89-100, 2003.

[3] FREIRE, P. Pedagogia do oprimido. 45 ed. São Paulo: Paz e Terra, 2005.

[4] ___. Educação como prática da liberdade, 34 ed. São Paulo: Paz e Terra, 2011.

[5] FOUREZ, G. Crise no ensino de ciências? Investigações em Ensino de Ciências, v. 8, n. 2, p. 109-123, ago. 2003.

[6] FURIÓ, C.,VILVHES, A., GUISASOLA, J.; ROMO, V. Finalidades de la enseñanza de lãs ciencias em la secundaria obligatoria. ¿Alfabetización científica o preparación propedéutica? Enseñanza de las ciencias, v. 19, n. 3, p. 365-376, 2001.

[7] JIMÉNEZ-ALEIXANDRE, M.P., BUGALlO RODRÍGUEZ, A. e DUSCHL, R.A. "Doing the Lesson" or "Doing Science": argument in high school genetics", Science Education, v.84, 757-792, 2000.

[8] KRASILCHIK, M.; MARANDINO, M. Ensino de ciências e cidadania. 2 ed. São Paulo: Moderna, 2011.

[9] LEMKE, J.L., Investigar para el Futuro de la Educación Científica: Nuevas Formas de Aprender, Nuevas Formas de Vivir, Enseñanza de las Ciencias, v.24, n.1, 5-12, 2006.

[10] LORENZETTI, L.; DELIZOICOV, D. Alfabetização Científica no contexto das séries inicias. Ensaio - Pesquisa em Educação em Ciências, v. 3, n. 1, p. 1-17, jun. 2001.

[11] SANTOS, W. L. P.; MORTIMER, E. F. Tomada de decisão para ação responsável no ensino de ciências. Ciência \& Educação, v. 7, n. 1, 95-111, 2001.

[12] SASSERON; CARVALHO, A. M. P. Almejando a alfabetização científica no ensino fundamental: a proposição e a procura de indicadores do processo. Investigações em Ensino de Ciências, Porto Alegre, v. 13, n. 3, p. 333-352, dez. 2008.

[13] ________ Alfabetização científica: uma revisão bibliográfica. Investigações em Ensino de Ciências - v. 16, n.1, p. 59-77, mar. 2011.

[14] TRAJANO, S. C. S. Alfabetização científica na formação de professores a distância: ideais comuns da prática de ensino em Ciências, uma proposta metodológica. Nilópolis, 2011. 112 f.. Dissertação (Mestrado em Ensino de Ciências) - Instituto Federal de Educação, Ciência e Tecnologia do Rio de Janeiro.

[15] UNESCO. The Plurality of Literacy and its implications for Policies and Programs: Position Paper. Paris: United National Educational, Scientific and Cultural Organization, 2011. Disponível em: <http://unesdoc.unesco.org/images/0013/001362/136246e.pdf.>. Acesso em 21 de jan. de 2016. 


\section{Capítulo 13}

\section{A docência na educação infantil: A constituição de uma docente de bebês}

\section{Maria Paula Ferreira Maia da Silva \\ Celi da Costa Bahia}

Resumo: No decorrer da história, uma nova concepção de Educação Infantil vem se consolidando e em se tratando, especificamente, do trabalho docente na creche surge a necessidade de romper com as marcas deixadas pelo assistencialismo. Neste contexto, as novas concepções de criança e da instituição escolar exigem a construção de uma identidade para atuação docente com os bebês e com as crianças pequenas. 0 objetivo deste trabalho é buscar refletir acerca da constituição de uma docente de bebês destacando o início da sua profissionalidade, marcado por muitas dúvidas, angústias e inseguranças, próprias de uma docente iniciante que encontrou nas relações estabelecidas - particularmente com os bebês, suas famílias e com os pares - dentro da Unidade de Educação Infantil as bases para construir uma prática educativa mais segura e intencional. A pesquisa realizada caracteriza-se por uma pesquisaação em que, conforme o processo de coleta das informações, as análises preliminares deram condições para ressignificar a prática docente a partir da compreensão das especificidades do processo de aprendizagem e desenvolvimento dos bebês. Utilizou-se para a coleta das informações a observação participante com registros no diário de aula, no qual as experiências da docente foram grafadas de forma descritiva duas vezes por semana. Os resultados da pesquisa apontaram à importância das relações estabelecias quer sejam com os pequeninos, quer sejam com as suas famílias, mas também com os pares no processo de aprendizagem sobre o trabalho docente com bebês em ambientes coletivos. Assim, o ser docente de bebês foi se constituindo nas relações formadas ao longo da trajetória profissional com os bebês e suas famílias, sobretudo com os pares dentro da instituição onde se exerce a docência.

Palavras-chave: Bebês. Prática docente. Reflexão da prática. 


\section{INTRODUÇÃO}

Historicamente, o trabalho em creches com as crianças pequenas foi marcado pelo assistencialismo, sendo prioridade a preocupação com o cuidado e a guarda das crianças de pais trabalhadores, porém, ao passar dos anos, uma nova concepção de creche vem se constituindo, entendida agora com função educativa. 0 que incidiu na necessidade do professor se dedicar aos estudos voltados aos bebês, que abordam como eles aprendem e se desenvolvem. Visto que é essencial ir além das marcas deixadas pela história e construir uma identidade para o professor de bebês, o qual ainda é classificado como um "cuidador", como alguém que simplesmente "repara" e "olha" os bebês das mães que trabalham. Contudo, destaca-se que os conhecimentos ligados à docência com bebês nem sempre são obtidos em cursos de formação de professores.

A partir disso, este trabalho busca refletir sobre a constituição de uma docente de bebês à luz das relações estabelecidas no contexto da Instituição de Educação Infantil, além do que se procura ainda discutir a respeito das dúvidas de uma docente iniciante e a construção de certezas aproximadas.

Para o alcance dos objetivos propostos utilizou-se como metodologia a pesquisa-ação, pois oportuniza, além de conhecer, ressignificar a prática docente no decorrer do processo de coleta e análise das informações registradas. E, a coleta das informações foi intercambiada pela observação participante, e para o registro delas utilizou-se o diário de aula, no qual, de forma descritiva e com riqueza de detalhes, durante duas vezes por semana, a professora fazia os registros que, sem dúvida alguma, subsidiaram a análise e discussão de sua prática pedagógica.

No decorrer do processo de pesquisa, foi possível perceber como a docente se constituía a partir da compreensão concernente ao processo de aprendizagem e desenvolvimento dos bebês, ocorrida por meio da relação com os mesmos, da relação com suas famílias e da partilha com os pares dentro da instituição. Essa compreensão se traduziu em uma prática educativa marcada pela intencionalidade, confiança e segurança, o que se traduzia na autoestima da docente.

\section{A DOCÊNCIA NA EDUCAÇÃO INFANTIL: A CONSTITUIÇÃO DE UMA DOCENTE DE BEBÊS}

A preocupação com a formação do docente que irá atuar na Educação Infantil assume um caráter legal a partir da Lei de Diretrizes e Bases da Educação Nacional (LBD) que define uma formação mínima, entendendo também a Educação Infantil como primeira etapa da Educação Básica.

Art. 62. A formação de docentes para atuar na educação básica far-se-á em nível superior, em curso de licenciatura, de graduação plena, em universidades e institutos superiores de educação, admitida, como formação mínima para o exercício do magistério na educação infantil e nos cinco primeiros anos do ensino fundamental, a oferecida em nível médio na modalidade normal. (BRASIL, 1996)

A priori, a compreensão acerca da necessidade de formação docente é ampliada pelas Diretrizes Curriculares Nacionais para Educação Infantil - DCMEI (resolução n. 05/09), quando tendo por base a LDB, responsável pela definição da finalidade da instituição que cuida e educa as crianças em idade inferior a seis anos e as concepções de criança e Educação Infantil, delineiam orientações para o trabalho educativo com as crianças pequenas.

0 reconhecimento de uma formação definida pela LDB e DCMEI se deve ao entendimento que a docência na Educação Infantil possui singularidades, que exigem bases teóricas e práticas, que possam oferecer fundamentação para o desenvolvimento intencional da prática pedagógica em ambientes coletivos. Pautada nesta compreensão no trabalho docente com bebês, é justificável promover uma profissionalidade, entendida como:

[...] um processo de constituição e identificação profissional, desenvolvido pelos professores ao longo de sua trajetória, nos diferentes espaços de socialização, desde a escolarização básica, a formação profissional, e, principalmente a organização escolar, onde os professores exercem e aprendem a profissão nesse exercício profissional. (AMBROSETTI; ALMEIDA, 2007, p. 4).

Tendo por base as ideias acima, a constituição da identidade do professor de Educação Infantil é um processo contínuo que, portanto, prolonga-se por toda a vida. No exercício profissional destacam-se as relações que ocorrem cotidianamente no contexto de trabalho como possibilidade de aprendizagem da docência com bebês. 
Desse modo, o primeiro passo é compreender que o ato educativo com os bebês acontece por meio das relações, pois eles têm um modo singular de se relacionar, sendo importante para o docente se despir da ideia de que eles precisam apenas de cuidado para sobreviver. Pelo contrário, eles possuem uma forma particular de expressar seus desejos e emoções, mas, tal relação somente é possível se o professor estiver aberto para estar e aprender com eles. Entende-se que "estar com os bebês significa colocar-se intencionalmente disponível para a relação" (COUTINHO, 2013, p. 9), dando sentido as suas falas, seus choros, balbucios, gestos, expressões, olhares, de modo a aguçar sua curiosidade e, assim, oportunizar novas descobertas, criações, curiosidades, necessidades e interesses.

0 que é óbvio para o adulto nem sempre o é para os pequeninos dai porque a relação com os bebês é indispensável para o seu processo educativo. Desde cedo, eles demonstram interesse de conhecer o mundo a sua volta e é claro que ao se relacionar com as pessoas e com os objetos eles se apropriam dos mesmos. Segundo Mello (2007, p. 90), a criança "é desde muito pequena, capaz de explorar os espaços e os objetos que encontra ao seu redor, de estabelecer relações com as pessoas, de elaborar explicações sobre os fatos e fenômenos que vivencia". Por isso, é necessário respeitar as crianças no tempo em que vivem dando espaço para suas formas típicas de exploração como: tatear, cheirar, tocar, sentir, ouvir.

Considerando que as relações ocorrem por meio das práticas sociais, o processo educativo ocorre por meio da indissociabilidade entre cuidado e educação. Para Guimarães cuidado envolve uma qualidade relacional, uma disposição para estar com os bebês. Neste sentido, os docentes de Educação Infantil tornam-se "mestres" do cuidar do cuidado das crianças.

Quando escutam, observam, dão visibilidade ou dialogam com os movimentos das crianças (em especial quando as crianças não se expressam verbalmente), indicam que seus gestos e expressões têm um valor. Não dirigir as crianças, mas incentiválas a se dirigirem, desenvolvendo autonomia, escolha e iniciativa é uma forma de cuidarem do cuidado da criança sobre si, desenvolver uma atenção da criança sobre si. (GUIMARÃES, 2011, p. 67).

Na essência, cuidado é entendido como a relação de escuta, de entrega, de atenção ao outro que se cuida. Assim, pode-se perceber que todos os momentos dentro da instituição são ricos em aprendizado para os pequeninos, como "os cuidados com higiene, alimentação, sono, proteção, amparo e aconchego podem ser ricos espaços de trocas afetivas, inserção social e estimulação" (TRISTÃO, 2008). Estes momentos tão simples da rotina revelam a sutileza da prática docente com bebês, determinantes para a caracterização desta profissão (TRISTÃO, 2004). Deste modo, o professor sensível e disponível para uma relação próxima com os bebês percebe a riqueza presente nas mais sutis e simples ações cotidianas de cuidado e educação que vivencia com cada bebê dentro da instituição.

Para além da relação com os bebês no trabalho desenvolvido para eles faz-se necessário estabelecer relações com as famílias, pelo fato delas poderem oferecer detalhes das necessidades, desejos e preferências de seus filhos, mas também apresentarem suas expectativas acerca do trabalho da instituição. Essa relação possibilita ao docente conhecer melhor os pequeninos e, consequentemente, cuidar e educá-los de modo compartilhado com as famílias.

Ainda que a compreensão do ser bebê e do seu processo de aprendizagem e desenvolvimento esteja claro na literatura, no cotidiano da instituição educativa a docência para eles ainda se encontra em construção. Nesse sentido, necessário se faz tempo e espaço para a reflexão partilhada com os pares no contexto da instituição com a finalidade de compreender o que é próprio da educação de bebês e da docência desenvolvida com eles.

Segundo Paige-Smith e Craft (2010), a prática reflexiva é vital para que os docentes da Educação Infantil possam ampliar seu desenvolvimento profissional, pois conduz o docente a tornar-se pesquisador de sua própria prática, construindo um conhecimento a partir de situações concretas, sustentado em teorias construídas. Certamente, todos os momentos de partilha permitem o encontro dos profissionais da instituição para que os mesmos reflitam acerca dos bebês concretos que estão no espaço, levando-os a assumirem uma prática reflexiva que possibilita o diálogo para além da teoria pela teoria, reconhecendo-a nas situações concretas que se vivencia no cotidiano das instituições. "Essencialmente, na prática reflexiva, tornamo-nos pesquisadores que se voltam ao próprio trabalho a fim de desenvolvêlo e melhorá-lo" (PAIGE-SMITH; CRAFT, 2010, p. 43).

Neste contexto, para que o docente de bebês torne-se pesquisador de sua prática e reflita sobre as situações concretas vivenciadas cotidianamente precisa adquirir elementos e fatos para alimentar a 
discussão, por isso, a importância da observação e do registro das interações e sinalizações dos bebês. Assim, é fundamental estar próximo aos bebês observando suas interações, ações, reações, falas, gestos, tendo em vista um olhar sensível, desabituado que perceba para além do habitual, do corriqueiro (OSTETO, 2008). 0 olhar atento permite perceber o que os bebês fazem e como eles sorriem, as suas falas, as suas insatisfações, os seus desejos e a sua vontade de aprender sobre o mundo que lhe cerca.

A partir das reflexões realizadas não se exclui a ideia de quanto o docente aprende nas relações que estabelece no contexto de trabalho. Este cenário, afirma que as relações influenciam na constituição do docente, especificamente, os que trabalham com bebês. Nessa perspectiva, este estudo pretende investigar o processo de constituição de uma docente de bebês à luz das relações que estabelece no contexto da instituição de Educação Infantil.

\section{PROCEDIMENTOS METODOLÓGICOS}

Para o alcance dos objetivos propostos utilizou-se como metodologia a pesquisa-ação, pois "a pesquisaação educacional é principalmente uma estratégia para o desenvolvimento de professores e pesquisadores de modo que eles possam utilizar suas pesquisas para aprimorar seu ensino" (TRIPP, 2005, p. 445).

A pesquisa foi realizada no ano de 2013 até 2014 , na UEI ${ }^{9}$ Wilson Bahia de Souza, que atende crianças na faixa etária entre zero e três anos em período integral. 0 número de crianças por turma varia conforme a idade. Especialmente, na turma do berçário que a pesquisadora desenvolvia seu trabalho docente, eram matriculados 15 bebês com idade entre 5 e 10 meses e era composta por seis professoras (três pela manhã e três pela tarde) com a tarefa de cuidar e educar os pequeninos. Em consonância com os pressupostos da pesquisaação, a pesquisadora foi o sujeito principal desta investigação.

Utilizou-se como procedimento de coleta de informações a observação participante, cujos registros das experiências da docente estavam grafados no diário de aula proposto por Zabalza (1994). Assim, duas vezes por semana registrava-se de forma descritiva e com riqueza de detalhes as vivências da professora destacando as relações por ela estabelecidas com os bebês, com suas famílias e com os pares dentro da instituição. Os registros feitos pela pesquisadora deram suporte à reflexão a respeito do processo de constituição da professora/pesquisadora, em que o mesmo foi marcado por dúvidas e inseguranças, mas também pela construção de certezas aproximadas do ser docente de bebês.

\subsection{DÚVIDAS E INCERTEZAS DE UMA DOCENTE INICIANTE}

Inicialmente, a análise dos registros revelou que as situações de aprendizagem estavam restritas ao cuidado, portanto, limitadas à exploração dos objetos existentes na sala. E, nas poucas tentativas de levar os bebês para a área externa, a preocupação central era garantir a segurança deles, dessa forma, tentavase reproduzir a estrutura existente em sala, como consequência poucas eram as possibilidades de exploração dos bebês. Nesse sentido, a reflexão de como a docente conduzia seu trabalho mostra o quanto a sua insegurança influenciava a sua prática pedagógica.

Ao lado da insegurança da professora, os bebês estavam cheios de necessidades para "curiosear" (DOOWBOR, 2007) o mundo, tentando sair do espaço definido por ela, contudo, eram interditados pelo seu atendo cuidado. Perante essa interdição lhes restavam possibilidades de explorar o mundo com seu olhar e gestos, que revelavam seus desejos de conhecer, sentir, cheirar, tocar. Mesmo assim, a professora não percebia o que os bebês lhes diziam com seus olhares, sorrisos e gestos, e se questionava acerca do que fazer com eles quando se encontravam sonolentos, porém, quando despertos demonstravam seu desejo de explorar o ambiente em suas diversas possibilidades.

0 caminho encontrado foi estudar sobre o processo de aprendizagem e desenvolvimento dos bebês, bem como sobre o trabalho a ser desenvolvido com e para eles. O que a princípio pode-se compreender, de acordo com o plano teórico, que para educar bebês em ambientes coletivos é fundamental que a professora esteja disponível para a relação com eles (COUTINHO, 2013), de modo a conhecê-los e dar sentido as suas sinalizações, pois cada pequeno gesto diz muito de seus desejos, suas insatisfações e sua forma de ser. Em razão disso, é importante estar disposto para a relação em todos os momentos: no banho, na alimentação, nas brincadeiras, nas situações de aprendizagem, na acolhida, os quais são ricos de aprendizado para os bebês.

\footnotetext{
${ }^{9}$ UEI - Unidade de Educação Infantil.
} 
A partir dessa compreensão, percebemos o quanto na docência com bebês a observação é indispensável. Ela permite conhecê-los e trabalhar na perspectiva de atender suas necessidades e potencialidades. Para tanto, é imprescindível desabituar o olhar (OSTETO, 2008) para compreender as sinalizações dos bebês, as vozes de quem ainda não fala, todavia, expressam-se por meio de seus olhares, de seus gestos, de seus balbucios e de seus sorrisos.

Ainda que a observação representasse a possibilidade de conhecer as singularidades de cada bebê integrante do grupo, ela apresentava limites em virtude dos pequeninos não dominarem a linguagem oral. Nesse sentido, a relação com as famílias tornou-se indispensável para ampliar o conhecimento da professora a respeito de os bebês e de suas famílias. Nesta perspectiva, buscou-se trazer as famílias para o espaço da UEI, seja nos momentos de reunião, seja participando de situações de aprendizagem com o intuito de criar laços de confiança e parceria. Esse processo desempenha um papel crucial para a docente compreender que a relação com as famílias é própria da docência com bebês, uma vez que não é possível educá-los sem o envolvimento das mesmas.

Aprender que a relação com os bebês e seus familiares é indispensável no processo educativo dos pequeninos foi fundamental, contudo, não suficiente. 0 tempo e espaço para a partilha entre os pares são necessários, pois favoreceram a discussão acerca de situações concretas da prática pedagógica com os bebês e possibilitou a segurança na tomada de decisões.

O processo de reflexão coletiva oportuniza a partilha de inseguranças e incertezas, mas também a ressignificação da prática docente, revelando que na relação dialógica o docente se abre para o novo, para a criação de possibilidades que fogem ao esperado (PAIGE-SMITH E CRAFT, 2010). Assim, quão importante significou a partilha com os pares no processo de aprender intercalado ao educar e ao cuidar de bebês em ambientes coletivos, o que demonstra que este trabalho é permeado pela ação coletiva, haja vista que:

Quando a troca de experiências ocorre no espaço institucional, permeada pela discussão teórica e alimentada pela riqueza das experiências cotidianas como fonte de estudo e reflexão, a escola se torna um contexto privilegiado de trabalho e formação, essencial na constituição da profissionalidade docente. (AMBROSETTI; ALMEIDA, 2007, p. 14).

Conforme compreendia o que é específico na docência com bebês, a professora oportunizava experiências mais ricas e desafiadoras para eles que ampliavam seus conhecimentos sobre o mundo e aguçavam sua curiosidade para continuar conhecendo. Essa percepção permitia que a professora fosse desenvolvendo seu trabalho com mais tranquilidade e segurança, o que gerava sentido para o que é ser docente de bebês. No entanto, o processo permanece porque outros saberes são construídos e mediados pelas relações estabelecidas no contexto da instituição, aproximando a docente de algumas certezas inerentes ao trabalho com bebês em ambientes coletivos.

\subsection{DAS DÚVIDAS AS CERTEZAS APROXIMADAS}

O processo de aprendizagem do professor caminhou ao lado do desenvolvimento do grupo de bebês, que ao longo do tempo iam se tornando mais independentes, espertos e seguros no espaço. Assim, a partir das aprendizagens construídas pela professora, o planejamento foi elaborado e balizado nas observações dos interesses dos bebês em manusear os livros e escutar histórias. Interesses que foram construídos pelo contato que os bebês tinham com os livros e pela presença da contação de histórias na rotina da UEI. Isto permitiu à professora compreender que no processo de aprendizagem e desenvolvimento dos bebês é importante explorar os livros e ouvir histórias. O que revelou quão importante é organizar o espaço para que os bebês possam agir sobre ele. Essa aprendizagem apenas foi possível pelo fato de que a docente se permitiu observar o quê e como os bebês faziam, suas preferências, desejos e interesses.

Aos poucos, observar as interações que os bebês estabeleciam se constituía em uma prática que alimentava o planejamento. As observações davam suporte significativo para os encaminhamentos pedagógicos e argumentos consistentes para justificar as escolhas que orientavam o trabalho desenvolvido com e para eles. Nesse processo, a docente pôde compreender que observar ultrapassa o simples olhar, é perceber os bebês em suas relações cotidianas dentro da instituição, desabituando o olhar livrando-se do "eu já vi isso", ou seja, é antes de tudo ter um "[...] olhar aberto, sensível, acolhedor" (OSTETO, 2008, p. 22).

A observação fornecia elementos para a discussão com os pares que, por sua vez, fundamentava o planejamento das ações, o que permitiu a ampliação das experiências dos pequeninos. De fato, o 
movimento de observar, discutir e planejar consentiu compreender que o trabalho com os bebês não apresenta resultado imediato, mas, cria possibilidades para que continuem aprendendo e se desenvolvendo.

Neste sentido, concorda-se com Tristão (2004) ao afirmar que a docência com bebês é uma profissão marcada pela sutileza das ações do docente que repensa seu planejamento para estar com os bebês, estabelecendo com eles relações de qualidade e percebendo suas mais simples manifestações. Tal sutileza está presente nos diálogos, nos choros, nos sorrisos e balbucios, nos gestos, nas expressões, assim como nas respostas dadas pela professora atenta que percebe com o seu olhar sensível os desejos dos bebês.

Portanto, estar com os bebês é compartilhar o protagonismo das escolhas em sala e dar espaço para o novo. É incluir o que não foi planejado inicialmente, é mudar os caminhos e abrir-se para a construção de novos saberes. E, no decorrer do processo de constituição da docente, as observações dos bebês ensinam que eles têm singularidades, tempo próprio, um modo de ser e estar, de viver a sua infância e de ser criança.

Outro aspecto que permeou o processo de constituição da docente foi a compreensão da importância da relação com as famílias. Ao acolher os bebês, a docente ia percebendo a cordialidade das famílias que chegavam para deixar seus filhos na unidade, isto revela que este processo é contínuo, ocorrendo durante o tempo em que os bebês frequentam o espaço da instituição.

Contudo, é necessário apresentar continuamente o papel da UEI para as famílias, especialmente, em virtude das marcas deixadas pelo assistencialismo, posto que os pais esperavam do espaço educativo ações voltadas ao cuidado com seus filhos, à prevenção contínua de acidentes, ao cuidado com as roupas, entre outras demandas constantes para as professoras. Para dar resposta às demandas apresentadas pelas famílias, a professora investiu em muito diálogo durante a entrada e saída dos bebês, bem como em reuniões com as famílias com o objetivo de explicitar o trabalho da instituição e construir uma relação de confiança e parceria na educação dos bebês.

À medida que se consolidava a compreensão sobre a importância da relação com as famílias, as ações com e para elas foram ampliadas passando a fazer parte das situações de aprendizagem que eram oportunizadas aos bebês, como exemplo os passeios pelo bairro que favoreceram aos pequeninos conhecer o mundo além dos muros da UEI, deste modo, eles andaram pelas ruas próximas da UEI, falaram com as pessoas que encontravam, participaram de um piquenique em área próxima da unidade e ainda foram convidados para conhecer um jardim.

Neste contexto, foi possível compreender que a acolhida das famílias é um processo que se dá em todos os momentos e de modo diversificado: ouvindo as famílias, partilhando informações sobre a instituição e promovendo a participação delas nas diversas experiências que são oportunizadas aos bebês. A exemplo dos professores é importante que a família participe e acompanhe o processo educativo dos seus filhos.

\section{CONSIDERAÇÕES FINAIS}

A partir das reflexões realizadas durante a pesquisa foi possível compreender que o processo de constituição docente não é uma linha reta. Ao contrário, ele é permeado por muitas dúvidas no processo de desenvolvimento do trabalho. Para tanto, o profissional precisa estar aberto para conhecer o que as pesquisas estão indicando e, além disso, permitir-se aprender com aqueles, independente da idade e do grau de escolaridade que venham a ter, que estão no cotidiano da instituição educativa, pois muito se pode aprender por meio das relações estabelecidas com eles.

Por meio da decisão de aprender com os bebês, enquanto docente, entendemos que os pequeninos não necessitam apenas de cuidados. Eles são seres com muito potencial para aprender, mas no seu processo educativo a observação é condição sine-qua-non, tendo em vista que eles muito nos dizem das suas necessidades, mas acima de tudo, das suas possibilidades, interesses e desejos também, sendo importante assimilar que eles têm uma forma singular de se expressar, razão pela qual o olhar sensível do docente é indispensável.

Apesar da relevância da observação dos bebês para o docente compreender a sua profissionalidade, ela não é suficiente. Assim, por meio da relação com as famílias tornou-se realidade a apreensão de que para educar bebês é indispensável trabalhar junto com as famílias. É, portanto, necessário construir com elas laços de confiança e parceria no cuidado e na educação dos bebês oferecendo para a família um espaço para ouvir, expressar seus pensamentos, desejos e anseios. 
Destaca-se ainda que a pesquisa permitiu a compreensão sobre a necessidade da reflexão. Entretanto, em virtude das especificidades do trabalho com bebês, ela é eminentemente coletiva, não abrindo mão de prover meios para assegurar o espaço para a reflexão com o coletivo de professores.

Em síntese, é possível afirmar que, por meio das relações estabelecidas na UEI, a docente foi se constituindo professora de bebê à medida que superava muitas dúvidas e se aproximava de algumas certezas. Nesse processo, compreendemos que sempre haverá dúvidas porque sempre surgirão demandas novas que exigem a resposta do docente. Por fim, acreditamos que a observação atenta e sensível aos bebês, o diálogo com as famílias e o processo de reflexão partilhada entre os pares darão condições para a construção de uma prática docente segura e intencional.

\section{REFERÊNCIAS}

[1] AMBrosetTi, N. B.; ALMEIDA, P.C.A. de. A Constituição da Profissionalidade Docente: Tornar-se Professora de Educação Infantil. In: ANPED, 30, 2007, Minas Gerais. 30 anos de pesquisa e compromisso social (Anais). Minas Gerais: 2007, p. 1-16. Disponível em: <http://30reuniao.anped.org.br/trabalhos/GT08-3027--Int.pdf.> Acesso em: 25 jul.2014.

[2] BRASIL. Lei de Diretrizes e Bases da Educação Nacional. Lei número 9394, 20 de

[3] dezembro de 1996. 8 ed. Brasília, 2013. Disponível em: < http://portal.mec.gov.br/arquivos/pdf/ldb.pdf> Acesso em: 20 jul. 2015.

[4] Coutinho, A. S. A. A prática docente com bebês. Revista Pátio-Educação Infantil. Ano XI, n. 35, abr/jun. 2013.

[5] CRAFT, A; PAIGE-SMITH, A. O que é refletir sobre a prática. In: O desenvolvimento da prática reflexiva na Educação Infantil. Porto alegre: Artmed, 2010. Cap. 1, p. 33-46.

[6] DOWBOR, F. F. Sobre "curiosear". In: Quem educar marca o corpo do outro. São Paulo: Cortez, 2007, p. 26-28.

[7] GUIMARÃES, D. Creche no Brasil: entre o higienismo e o cuidado. In: . Relações entre bebês e adultos na creche: o cuidado como ética. Cortez: São Paulo, 2011. P 27-54.

[8] MELLO, S. A. Infância e humanização: algumas considerações na perspectiva históricocultural. Florianópolis: Perspectiva. v. 25, n. 1, p. 83-104, jan/jun.2007.

[9] OSTETO, L. E. Observação, registro, documentação: nomear e significar as experiências. In:

[10] ___ (Org.). Educação Infantil: saberes e fazeres da formação de professores. Campinas: Papirus, 2008, p.1332.

[11] TRIPP, D. Pesquisa-ação: uma introdução metodológica. Educação e Pesquisa. São Paulo, v.

[12] 31, n. 3, p. 443-466, set./dez. 2005. Disponível em:< http://www.scielo.br/pdf/ep/v31n3/a09v31n3.pdf> Acesso em: 20 jul. 2015.

[13] TRISTÃO, F. C. D. Ser professora de bebês: uma profissão marcada pela sutileza. Zero a Seis. v. 6. n. 9. jan/jun. 2004. Disponível em:

[14] <https://periodicos.ufsc.br/index.php/zeroseis/article/view/9360> Acesso em: 3 jun. 2014.

[15] _ _. Cuidado é Educação: o trabalho com bebês. Avisa Lá. n.33, jan 2008. Disponível em: < http://avisala.org.br/index.php/assunto/jeitos-de-cuidar/cuidado-e-educacao-o-trabalhocom-bebes/> Acesso em: 8 dez. 2014.

[16] ZABALZA, A.M. Diários de aula- contributo para o estudo dos dilemas práticos dos professores. Portugal, Porto Editora, 1994. 


\section{Capítulo 14}

\section{A formação do (a) professor (a) alfabetizador (a): Um olhar crítico para a sua prática}

\section{Amanda Tayse de Sena Silva Santos \\ Manuella Patricio Menezes \\ Maria do Socorro Moura Montenegro}

Resumo: Sabemos que nos dias de hoje é desafio de, enquanto professoraalfabetizadora, ter a uma prática de ensino mais diversificada, mais singular, seja com intervenções coletivas e/ou individuais. Esta é uma reflexão que se deve considerar no processo de alfabetização, desde que entendamos a criança como sujeito que pensa e reflete sobre aquilo que aprende e sobre o que lhe é ensinado, a partir do momento em que elabora hipóteses e reflete sobre as mesmas. É com base nisso, que o objetivo geral desse artigo é refletir acerca da valorização dos saberes produzido a partir da ação pedagógica do professor alfabetizador, compreendendo que a concepção da prática pedagógica como fonte de saberes não supervaloriza a prática, mas reconhece que as ações dos professores, de modo geral, são alicerçadas em suas crenças e teorias acerca da educação, do ensino e do ser professor. Percebemos, assim, que a formação inicial dos professores alfabetizadores não é suficiente para o exercício de uma prática docente com eficiência, pois deixa lacunas na formação, não atendendo totalmente às necessidades dos docentes. Partindo dessas abordagens, o presente artigo trata-se de estudo de uma abordagem qualitativa, do tipo pesquisa exploratória, tendo sido utilizado como instrumento para coleta de dados uma entrevista com perguntas abertas, realizada com uma professora do $1^{o}$ ano do Ensino Fundamental da rede pública de ensino do município de Queimadas-PB.Vale ressaltar que esse artigo resultou de estudos, em sala de aula, no componente curricular: Alfabetização e Letramento no curso de Pedagogia, semestre 2017.2.

Palavras - chave: Alfabetização. Prática pedagógica. Saberes docente 


\section{INTRODUÇÃO}

0 processo de alfabetização no contexto brasileiro tem sido objeto de muitas reflexões, revelando a necessidade de superação de práticas mecanicistas que situam o professor como um tecnólogo. Essas reflexões indicam a necessidade de pensarmos e de efetivarmos a alfabetização de crianças como um processo articulado ao letramento, às práticas sociais de usos da língua escrita. Para tanto, requer um professor como mediador das aprendizagens no processo de aquisição da leitura e da escrita.

Os estudos acerca da prática pedagógica alfabetizadora, no sentido de compreendê-la como prática sociocultural, postulam a viabilização de práticas leitoras e escritoras reais, contextualizadas. É importante, pois, compreender o processo de aquisição da língua escrita articulando-o aos processos de letramento.

Assim, o presente artigo teve a necessidade de demonstrar a partir de uma revisão bibliográfica de como se dá a prática do professor (a) alfabetizador (a). Destaca-se ainda que se faz necessário discutir os desafios e perspectivas além de analisar a narrativa da professora entrevistada dentro da realidade atual. Tivemos como objetivos específicos (1) refletir sobre a formação do professor (a) alfabetizador (a), (2) analisar através de uma entrevista semi estruturada o modo de como a professora entrevistada foi se construindo alfabetizadora no exercício da docência e (3) abordar os desafios enfrentados pela mesma.

\section{REFLEXÃO SOBRE A FORMAÇÃO DA PROFESSORA ALFABETIZADORA}

Durante muito tempo pensou-se que para ensinar bastava saber. Vemos aí uma grande idéia de utopia inserida. Vemos uma humanidade aparentemente perdida. Podemos analisar que essa complexidade das relações vividas no trabalho docente tem alterado significativamente essa visão.

Mas vemos ainda uma situação muito distante do que podemos considerar o ideal. A educação sempre fica com o pior, com o último. 0 município, estado ou país não visualiza a educação como uma prioridade. Vemos sim nas TV's falas de grande importância, mas quando olhamos o real podemos notar que nada é como deveria ser.

Espera-se que a educação no Brasil resolva, sozinha, os problemas sociais do país. No entanto, é preciso primeiro melhorar a formação dos docentes, visto que o desenvolvimento dos professores implica no desenvolvimento dos alunos e da escola.

Certamente, os professores não podem ser tomados como atores únicos nesse cenário. Podemos concordar que tal situação também é resultado de pouco engajamento e pressão por parte da população como um todo, que contribui à lentidão. Ainda sem citar o corporativismo das instâncias responsáveis pela gestão não só do sistema de ensino, mas também das unidades escolares.

Os aspectos moldados no trabalho docente vêm ao encontro do conhecimento posto em ação, das decisões tomadas no momento da ação educativa, das pequenas escolhas, da postura e dos argumentos que o professor faz uso para validar as suas ações frente a seus pares.

A atitude de tolerância está longe de guardar o ranço de um populismo sempre autoritário, tenta romper com uma postura iluminista igualmente autoritária.

Com o ritmo acelerado de mudanças na educação, pensar na formação inicial do professor, ofertada nos cursos de graduação, como suficiente para todas as demandas que a escola apresenta não é mais possível. 0 aprender mais sobre a sua profissão durante a prática educativa e o desenvolvimento profissional atrelado à formação continuada são requisitos cada vez mais exigidos dos professores.

Segundo García (1996), para José de Souza Martins, Carlos Ginzburg, e o sempre atual Paulo Freire todos ele tem ajudado a buscar uma compreensão do conhecimento produzido pelas professoras e crianças. Essa tal conhecimento tão essencial para nosso crescimento como pessoa e aluno. Conhecimento qual muitas vezes não é valorizado previamente.

Conseqüentemente a sala de aula se torna um espaço de produção de uma teoria prática a partir da visão da professora com visão para criança como ela aprende. Tem que existir uma preparação, uma capacitação para o professor, pois se torna indispensável.

A sala de aula é um espaço de construção, desconstrução e reconstrução de conhecimento. A professora é portadora de uma teoria adquirida em seu curso de formação inicial. Teoria que a levara para sala de aula onde ela colocara em prática tudo que foi aprendido mais claro com a visualização do novo que o aluno trará com sigo. Também poderá ter um conhecimento mais amplo em reuniões pedagógicas com outras 
professoras e experiências trazidas de fora da sala de aula vivenciadas, leituras que fez ao longo do curso e reflexões. Para assim observa o que não observava mais, aprender a ver com outros olhos a educação para assim acreditar na sua capacidade e mostra em sala de aula o que é capaz para ajudar seus alunos.

Mesmo nos conteúdos mais estanques, sobre os quais o professor já tem um repertório de conhecimentos bem fundamentado, novas questões, dúvidas dos alunos e pequenos desentendimentos podem levar o professor à reflexão, à pesquisa e a uma nova compreensão da matéria ensinada, portanto, ocorre aprendizagem pela prática profissional e/ou durante ela.

0 conhecimento que o professor já dispõe e o conhecimento que ele produzira a partir das pesquisas e estudos. Como Vigotsky (1984) fala que os professores em seu cotidiano podem mostrar seus brotos que um dia poderão reproduzir frutos suculentos.

A alfabetização é um direito humano e as bases para a aprendizagem ao longo da vida. Capacita indivíduos, famílias e comunidades e melhora a sua qualidade de vida. Por causa de seu "efeito multiplicador", a alfabetização ajuda a erradicar a pobreza, reduzir a mortalidade infantil, conter o crescimento populacional, a alcançar a igualdade de gênero e assegurar o desenvolvimento sustentável, a paz e a democracia. A educação é para todos independente de classe social, raça ou gênero.

Por isso, devemos proporcionar um ambiente educacional que privilegie o diálogo onde existe aluno professor. Os desafios educativos colocados pela sociedade atual e pelo trabalho docente são cada vez mais exigentes e estão em constante mutação e podemos ver como cresce em grande escala os desafios em sala de aula

Abordando a questão histórica, por muitos anos a educação estruturava-se colocando o professor como centralizador do conhecimento e o aluno como uma tabula rasa que deveria ser preenchida com informações que seriam transmitidas pelos docentes. Podemos ver a importância do professor pesquisador. Tanto ele aprendera com os alunos como o poderá procura cursos que poderão ajudar em seus dia a dia.

Mas para termos a educação como fonte transformadora do ser humano e da sociedade é preciso que o professor se coloque como mediador e em contínuo processo de formação, e essa não é uma tarefa fácil. Para ver coisas novas é necessário renovar o olhar e desprender-se das antigas idéias. 0 desejo do professor terá sempre que ser melhorar a sua prática pedagógica.

O professor é uma pessoa em construção, portador de um nó formativo central e contínuo, sincronizado com o seu tempo. Ser professor hoje implica assumir uma profissão que está em constante processo de redefinição e ressignificação.

Desse modo, o ato de ensinar e aprender são de pura criatividade. E é com esse diálogo e trocas que o professor auxilia seus alunos na aprendizagem, assim também se aproxima por meio da afetividade.

\section{ANÁLISE E DISCUSSÃO DE RESULTADOS}

Hoje em dia, ser alfabetizado, no sentido amplo de saber ler e escrever, tem se mostrado uma condição insuficiente para responder adequadamente às demandas da sociedade, já que a alfabetização deve se desenvolver em um contexto de letramento como processo da aprendizagem da escrita, como desenvolvimento de habilidades de uso da leitura e da escrita das práticas sociais que envolvem a língua escrita, e de atitudes de caráter prático em relação a esse aprendizado.

Desse modo, trazemos as questões referentes à entrevista e análise realizada com a professora entrevistada, sendo esta alfabetizadora do $1^{\circ}$ ano do Ensino Fundamental, no município de Queimadas-PB.

\subsection{QUE SERIA ALFABETIZAÇÃO?}

Para mim, é a capacidade e habilidade de uma criança ler e escrever de forma adequada, onde estará desenvolvendo suas capacidades diariamente (RESPOSTA DA PROFESSORA).

Através da resposta da professora é possível refletir que forma adequada seria essa? 0 que é o certo e o que é errado na perspectiva da professora? 0 professor deve criar as condições necessárias para a alfabetização, pois temos consciência de que ela não forma leitores sozinha, mas sabemos também que a mediação e é fundamental para ajudar nessa formação já que as crianças muitas vezes aprendem o código, a mecânica, mas depois não aprendem a usar. 
Assim sendo, a tarefa de alfabetizar significa dar subsídios aos alunos, e o mais importante: de acordo com suas necessidades e realidade, para que estejam preparados, havendo assim uma escolarização real e efetiva, desenvolvendo nos alunos um conjunto de habilidades e comportamentos de escrita e leitura que lhes permitam fazer uso, de modo que não fiquem tão presos aos conhecimentos especificamente lingüísticos.

É preciso que o professor conheça a realidade de cada aluno sem exclusões, conheça sua prática e não desconsiderem o que os mesmos já trazem de conhecimentos prévios, a partir do cotidiano e suas relações sociais. É necessário também que a professora reflita sobre sua prática para que não caia na "mesmice" não se limitando apenas à codificar e decodificar textos.

\subsection{DISCUSSÃO SOBRE SUA CONSTRUÇÃO E HISTÓRIA COMO PROFESSORA}

Bom, sempre quis ser professora desde minha infância, ingressei na escola normal e os 17 anos, passei no vestibular para Pedagogia (UEPB) paralelamente ao curso lecionava. Desde sempre a profissão de professora me cativou e se tornou um desejo, e cada vez mais mim (sic) identificava o prazer de ver as crianças se descobrindo e descobrindo o mundo é algo fantástico e que me encanta e me motiva cada dia é ter o incentivo para continuar e acreditar que a educação é a porta aberta para um futuro brilhante (RESPOSTA PROFESSORA).

Nessa resposta a professora expressa, de fato, amor pela profissão. E mesmo com os desafios na educação, ela demonstrou que não podemos desistir nunca e acreditar sim a educação é a chave para um futuro melhor. Esperança é o sentimento que devem seguir e perseguir os professores para que a educação seja transformadora da sociedade.

Portanto, não está tão claro o que significa que "a educação é uma porta aberta para p futuro", embora dê a entender que, sem educação, teremos um futuro promissor.

\subsection{SOBRE DIFICULDADES E PROVIDÊNCIAS PARA ALFABETIZAR}

Busco nas estratégias para que todos os objetivos almejados sejam alcançados (REPOSTA PROFESSORA).

A resposta da professora foi de certa maneira um pouco "vaga". Fica a dúvida de que estratégias são essas? De fato, cabe aos professores instigar seus alunos para a prática tanto da leitura, como da escrita, e isso se dá através de incentivos variados, no que diz respeito a diversos tipos de escrita, utilização de exercícios de interpretação e compreensão, além de vários outros tipos de ferramentas como revistas, jornais, internet, etc..

O processo de ensino-aprendizagem de leitura e de escrita na escola não pode ser configurado como um mundo à parte e não ter a finalidade de preparar o sujeito para a realidade na qual se insere. Então, podemos dizer que, ensinar na perspectiva do letramento significa não somente levar o aluno a ser um analista de sua língua, mas, sobretudo um usuário consciente de que cada habilidade lingüística tem um espaço específico de uso, ocorre de forma diferenciada e deve estar adequada à situação de comunicação.

Segundo García (1996), o professor deve aprender a ver com outros olhos, escutar o que antes não prestava atenção e relacionar o que não lhe parecia ter nenhuma relação. E, de fato, o professor deve ser investigador, curioso a fim de buscar melhorias para seus alunos.

Contudo, essa melhoria pode se dá através da mediação. Para Vygotsky a mediação presente em toda a vida humana em que usamos técnicas e signos para fazermos mediação entre seres humanos e estes com o mundo. A linguagem é um signo mediador por excelência por isso Vygotsky a confere um papel de destaque no processo de pensamento e afirma que "aquilo que é zona de desenvolvimento proximal hoje será o nível de desenvolvimento real amanhã, ou seja, aquilo que uma criança pode fazer com assistência hoje, ela será capaz de fazer sozinha amanhã" (VYGOTSKY, 1984, p. 98).

Desse modo, é possível elaborar estratégias pedagógicas para que a criança possa evoluir no aprendizado. 0 mediador ou professor alfabetizador ajuda a criança a concretizar o desenvolvimento que está próximo, ou seja, ajuda a transformar o desenvolvimento potencial em desenvolvimento real.

\section{CONSIDERAÇÕES FINAIS}

Esse estudo resultou de um estudo desenvolvido no componente curricular: Alfabetização e Letramento, 
do curso de pedagogia, semestre 2017.2. Entre as reflexões desenvolvidas, aqui, está o fato de que, através de uma prática pedagógica que possibilite a construção de novos saberes, deve ser de extrema importância dos profissionais docentes. Os saberes docentes são componentes importantes na construção da profissão e da identidade da profissão, uma vez que estes vêm recebendo atenção por parte de inúmeros pesquisadores, evidenciando a singularidade dos mesmos, pois caracterizam o ser professor.

Portanto, percebemos que na prática pedagógica alfabetizadora, por apresentar-se uma prática complexa, os professores precisam apropriar-se de tais saberes para torná-las mais eficiente.

A formação deve ter como eixo referencial o desenvolvimento pessoal do professor alfabetizador, na dupla perspectiva do professor individual e do coletivo docente. Estar em formação significa investimento pessoal e que a formação pode estimular o processo de desenvolvimento profissional dos professores. Mas, não basta somente esta formação, mas também se deve investigar pesquisar métodos de cada criança necessita usar a criatividade e refletir sobre sua prática docente ocupando um papel de agente transformador na tomada de decisões.

Concluí-se sobre a relevância em aprofundar os estudos sobre a formação docente, contemplando os professores que atuam na alfabetização, no sentido de buscar ouvir seus percursos e trajetórias profissionais, além de levantar suas dificuldades e providências.

\section{REFERÊNCIAS}

[1] GARCIA, Regina Leite. A Formação da Professora Alfabetizadora. São Paulo: Cortez, 1996.

[2] PIMENTA, S. G. Saberes pedagógicos e atividade docente. São Paulo: Cortez, 1999.

[3] VIEIRA, H. M. Prática pedagógica do professor alfabetizador: a reflexão crítica como mediador do saber, do saber-ser e do saber-fazer. Campus Ministro Petrônio Portella Teresina - PI. Dissertação de Mestrado. Teresina: UFPI, 2007.

[4] VYGOTSKY, Lev S. A formação social da mente. São Paulo: Martins Fontes, 1984. 


\section{Capítulo 15}

Necessidades formativas docentes para alfabetizar letrando em salas multisseriadas: 0 estabelecido nos documentos oficiais e a perspectiva de professoras

\section{Telma Maria de Freitas Araújo \\ Maria Estela Costa Holanda Campelo}

Resumo: Este estudo, parte de uma pesquisa de Mestrado em andamento, analisou necessidades de formação de professoras alfabetizadoras que atuam em salas multisseriadas do Ciclo de alfabetização de escolas rurais, em Espírito Santo/RN, no contexto dos conteúdos transversais para alfabetizar letrando. Como principais autores: Soares (2003); Campelo (2001); Rodrigues (2006); Rodrigues e Esteves (1993); Antunes-Rocha e Hage (2010) e documentos oficiais. A metodologia é de um estudo do tipo etnográfico, de abordagem qualitativa, tendo como procedimentos metodológicos: questionário; observação participante; entrevista semiestruturada; análise documental e a técnica balanço do saber. Os campos empíricos foram três escolas municipais rurais, cujos sujeitos foram três professoras de salas multisseriadas do Ciclo de Alfabetização. Os resultados preliminares têm nos permitindo refletir sobre a importância de estudos relativos às necessidades de formação dos professores.

Palavras-chave: Alfabetização e Letramento. Necessidades Formativas. Salas Multisseriadas da Educação do Campo. Conteúdos Transversais. 


\section{INTRODUÇÃO}

O estudo é parte da nossa pesquisa de Mestrado - Projeto aprovado pelo Comitê de Ética em Pesquisa (HUOL/UFRN), sob o Parecer n. 2.247.175. A investigação se originou de preocupações com o insucesso escolar na alfabetização de crianças do sistema público de educação, direcionando nosso olhar para a formação do professor alfabetizador que atua em classes multisseriadas da Educação do Campo, no município de Espírito Santo/RN.

Frente aos novos desafios que vive a educação, estudiosos da área, governos e gestores reconhecem que a formação contínua de professores é o caminho viável e possível na contribuição para a melhoria na qualidade de ensino. Entretanto, o que percebemos é que há um número razoável de professores que dominam os conteúdos a serem ministrados, mas, por outro lado, evidenciamos grande desconhecimento dos aspectos pedagógicos essenciais no processo de ensinar, tais como: estratégias diferenciadas de trabalhar os conteúdos; gestão da sala e da disciplina; avaliação dos alunos; planejamento da ação docente, dentre outros. (GHEDIN; ALMEIDA; LEITE, 2008).

Assim sendo, pelo fato desses professores não compreenderem como tais aspectos pedagógicos precisam estar articulados, emerge a necessidade de uma formação contínua que leve em conta as reais necessidades formativas destes professores, para que possam combater as desigualdades escolares e o baixo desempenho na aprendizagem dos alunos. Consideramos que o professor é um dos elementos mais importantes na busca de uma educação de qualidade, ressaltando que a tão discutida excelência profissional encontra-se vinculada às condições de trabalho e à formação inicial e continuada desse profissional.

Justificamos o estudo na medida em que a análise de necessidades de formação contínua de professores alfabetizadores que atuam em salas multisseriadas, sobretudo na perspectiva de alfabetizar letrando, constitui-se em uma área de pesquisa fértil. Ademais, as pesquisas no âmbito desta temática valorizam a perspectiva dos professores que, na qualidade de sujeitos e não de objetos da pesquisa, são convidados a refletirem sobre a própria prática pedagógica e a nos dizerem acerca de suas necessidades de formação docente.

Nesse contexto, definimos como objeto de estudo do nosso trabalho - necessidades da formação docente de professores para alfabetizar letrando alunos no contexto de salas multisseriadas da Educação do Campo. Nesse sentido, objetivamos investigar necessidades formativas que têm se evidenciado no exercício docente de alfabetizar letrando alunos do Ciclo de Alfabetização de salas multisseriadas de Escolas do Campo.

\section{ALFABETIZAÇÃO, LETRAMENTO E ALFABETIZAR LETRANDO NO CICLO DE ALFABETIZAÇÃO}

Na discussão que segue, emerge a necessidade de abordar como o processo de alfabetizar no contexto do letramento ocorre na Educação do Campo, suas aproximações e distanciamentos, sobretudo em salas multisseriadas. Em nível nacional e regional, o desafio de promover a escolarização desses alunos tem como principais entraves as desigualdades aparentes que apontam a necessidade de implementação de políticas educacionais no sentido de reverter o quadro de analfabetismo que predomina no país.

Segundo Carvalho (2005), sobre a inserção do sujeito na sociedade e conquista da cidadania, exige-se que este esteja alfabetizado e domine as habilidades da linguagem por meio de práticas sociais que envolvam a leitura e a escrita, considerando o sujeito letrado - aquele que consegue utilizar, no seu cotidiano, estas habilidades, sendo capaz de modificar sua realidade. Para a autora, "a alfabetização e o letramento são questões emblemáticas que se referem a problemas de ordem social e educacional resistentes às inúmeras tentativas de solucioná-los na sociedade brasileira". (CARVALHO, 2005, p. 45).

No Brasil, por muitos anos, ser alfabetizado correspondia a simples capacidade de a pessoa escrever o próprio nome (MACIEL, 1999).

Na década de 1940, o conceito de alfabetização se restringia à habilidade de codificar (escrever) e de decodificar (ler). Ainda no nosso país, a superação de uma economia agrária por um modelo mais urbano e industrial de organização social converteu em necessidade premente o acesso à educação e à alfabetização. Essa transformação impulsionou mudanças na forma de se conceituar a alfabetização.

Nos anos de 1950, a alfabetização passou a ser conceituada com base na capacidade de se compreender o que lia e se expressar através do que escrevia. Nas décadas de 1960 e 1970, passou a abranger a capacidade de leitura e escrita - agora, já envolvendo a compreensão -, além do preparo para o 
desempenho dos papéis social, cívico e econômico, que deveria contribuir para a libertação e o desenvolvimento das pessoas (MACIEL, 1999).

Mesmo que consideremos os dois conceitos, ou seja, alfabetização como o domínio do código de transcrição de fonemas em grafemas e alfabetização como processo de compreensão e expressão de significados, estas concepções podem ser consideradas incompletas, uma vez que não contemplam a total complexidade da alfabetização e se detêm, apenas, nos aspectos individuais das aquisições advindas da alfabetização (SOARES, 2003).

Nessa perspectiva, é importante lembrar que um conceito mais abrangente de alfabetização, que compreenda também os usos e funções sociais da língua escrita, remete a outro conceito - o letramento, que "tem suas origens na palavra inglesa literacy, que designa o processo de inserção no mundo da escrita" (SOARES, 2003, p. 91).

Maciel (1999, p. 22) explica que é preciso ser e estar alfabetizado. Para isto, “[...] não basta saber ler e escrever; é preciso igualmente ser competente para utilizar as habilidades de ler e escrever, atendendo às exigências de leitura e escrita que a sociedade faz continuamente".

Carvalho (2005, p. 66) explica que uma pessoa letrada “[...] é alguém que se apropriou suficientemente da escrita e da leitura, a ponto de usá-las com desenvoltura, com propriedade, para dar conta de suas atribuições sociais e profissionais".

Nesse sentido, percebemos que os conceitos de alfabetização e letramento são processos simultâneos e interdependentes. Soares (2003, p.16) enfatiza que "[...] Não se trata de primeiro aprender a ler e escrever para só depois usar a leitura e a escrita, mas aprende-se a escrever por meio do uso da leitura e escrita em práticas reais de interação com a escrita". Entretanto, é possível que uma pessoa seja alfabetizada, mas não seja capaz de fazer uso da língua escrita no seu dia a dia; ou que uma pessoa que não domina o sistema alfabético, consiga fazer este uso, nem que seja por intermédio de uma pessoa alfabetizada. Assim, nos fala Soares (2003, p. 92):

A alfabetização - a aquisição da tecnologia da escrita - não precede nem é pré-requisito para o letramento, isto é, para a participação em práticas sociais de escrita, tanto assim que analfabetos podem ter um certo nível de letramento: não tendo adquirido a tecnologia da escrita, utilizam-se de quem a tem para fazer uso da leitura e da escrita.

Dessa forma, é interessante enfatizar que, considerando um contexto social em que é constante o uso cotidiano da língua escrita e da leitura, ou seja, numa sociedade letrada, não podemos falar num grau zero de letramento, ou iletrados absolutos, visto que, de alguma forma - seja com mais autonomia, ou menos autonomia - o indivíduo participa dessas práticas (MORTATTI, 2004).

Assim, para se efetivar a alfabetização no contexto do letramento é necessário que o professor oportunize contextos significativos. Para isso, é essencial conhecer as especificidades e relações entre os conceitos de alfabetização e letramento. A perspectiva de 'alfabetizar letrando' aparece nos estudos de autores como Soares $(2000,2003)$, Leite $(2001,2006)$, Albuquerque $(2005)$, bem como vem "sendo incorporada pelos programas oficiais e instrumentos de avaliação do MEC utilizados nos anos iniciais do Ensino Fundamental para diagnosticar a situação de alfabetização das crianças brasileiras". (VIEIRA, 2010, p. 124).

Nesta direção, garantindo a autonomia e respeitando as especificidades do sujeito do campo, faz-se necessário também respeitar o saber linguístico de cada indivíduo. Portanto, para Cagliari (2001, p. 81), o professor não pode desconsiderar que:

[...] os modos diferentes de falar acontecem porque as línguas se transformam ao longo do tempo, assumindo peculiaridades características de grupos sociais diferentes, e os indivíduos aprendem a língua ou dialeto da comunidade em que vive.

Em práticas pedagógicas existentes, o professor alfabetizador ainda desconhece a realidade linguística do aluno do campo, bem como todos os conhecimentos que ele adquire durante sua vida e acaba rotulando-o por não usar a língua padrão.

Nesse contexto, Soares (2003) afirma que a escola que alfabetiza letrando é aquela que organiza situações de aprendizagem em que a apropriação dos gêneros textuais é o eixo central do ensino, garantindo o 
domínio do funcionamento do sistema alfabético com vistas ao engajamento autônomo do aluno nos eventos sociais mediados pela escrita.

\subsection{O CONTEXTO DA SALA MULTISSERIADA NA EDUCAÇÃO DO CAMPO: NECESSIDADES FORMATIVAS PARA ALFABETIZAR LETRANDO}

A discussão e o debate em relação às especificidades do homem do campo surgem em um contexto marcado por avanços e reivindicações dos movimentos sociais na luta pela garantia dos direitos, materializada, sobretudo pelo acesso à terra.

Nesse sentido, Fernandes et al (2004, p. 137) definem o campo como:

[...] lugar de vida, onde as pessoas podem morar, trabalhar, estudar com dignidade de quem tem o seu lugar, a sua identidade cultural. 0 campo não é só o lugar da produção agropecuária e agroindustrial, do latifúndio e da grilagem de terra. 0 campo é espaço e território dos camponeses e dos quilombolas [...].

Em conformidade com as Diretrizes Operacionais para Educação Básica nas Escolas do Campo (BRASIL, 2013, p. 5), a Educação do Campo, também denominada educação rural, tem um significado "que incorpora os espaços da floresta, da pecuária, das minas e da agricultura, mas os ultrapassa ao acolher em si os espaços pesqueiros, caiçaras, ribeirinhos e extrativistas". Assim, mais do que um perímetro não urbano, o campo é visto como espaço de possibilidades que "dinamizam a ligação dos seres humanos com a própria produção das condições da existência social e com as realizações da sociedade humana".

Contudo, as políticas educacionais implantadas e implementadas no Brasil continuam a ignorar as necessidades e especificidades da escola do campo, tratando-a como extensão da escola urbana.

E as salas multisseriadas? 0 que são? Estas são uma forma de organização escolar em que alunos de diferentes idades e tempo ou níveis de escolarização (o que se conhece por série) ocupam uma mesma sala de aula, sob a responsabilidade de um mesmo professor. Presentes no contexto do campo, as escolas multisseriadas são frutos de um período histórico que nos remete ao Brasil colônia, com professoras leigas e ambulantes que davam aulas aos filhos dos donos das terras e, por consequência, aos filhos dos seus trabalhadores, após a expulsão dos jesuítas do país em 1759. (ANTUNES-ROCHA; HAGE, 2010).

No Brasil, como explicam Azevedo e Queiroz (2010), a escola do campo traz como característica marcante um modelo submisso aos conteúdos ministrados e aprendidos nas cidades, partindo do princípio do atraso das culturas e da falta de perspectivas desse meio. Essa perspectiva de subordinação está retratada nas Diretrizes Operacionais para Educação Básica nas Escolas do Campo, que reconstrói a concepção de descaso com a educação nesse contexto. Uma educação "no campo e do campo" irá legitimar a educação como um direito social, segundo Arroyo, Caldart e Molina (2004, p. 15).

Essa perspectiva de subordinação aos conteúdos do contexto urbano ainda se encontra muito presente nas práticas pedagógicas desenvolvidas nas escolas rurais, sobretudo em relação aos conteúdos elencados nas propostas pedagógicas.

Segundo dados da Secretaria de Educação Continuada, Alfabetização, Diversidade e Inclusão-SECADI (BRASIL, 2013), mesmo com o intenso processo de nucleação vivido nesse período, ainda existe no território nacional mais de 50 mil escolas multisseriadas no campo. Essa expressiva quantidade traz à tona a necessidade de estabelecerem políticas de formação de professores voltadas ao atendimento dessa especificidade pedagógica.

Para tanto, os princípios fundamentais para a formação de professores que atuam em escolas/classes multisseriadas do campo precisam articular-se com a Educação do Campo, compreendendo-a como acúmulo da luta dos trabalhadores do campo, que percebem a importância e a necessidade de ampliá-la para além do acesso à terra. Segundo Caldart (2008) e Molina (2009), a educação vai sendo incorporada, gradativamente, como fundamental nesse processo. Coloca-se na agenda nacional o 'campo brasileiro' em seus diferentes aspectos, com ênfase na educação e na discussão de um projeto de sociedade, denunciando a precariedade das escolas do campo e a necessidade de formação para os professores que atuam nas mesmas.

D’Agostini, Taffarel e Santos Júnior (2012, p. 320) afirmam a necessidade de uma fundamentação teóricocrítica da educação, que permita "[...] alterações na prática pedagógica e para a elevação do padrão cultural 
de professores e estudantes no Brasil", no sentido de que o professor se aproprie de uma teoria aliada à prática, cuja concepção subjaz aos estudos de Vygotsky (1991).

Nesse contexto e em concordância com os autores (2012), um dos conceitos que consideramos essencial para contribuir com a discussão sobre a formação docente e a organização do trabalho pedagógico nas salas multisseriadas da Educação do Campo é o de nível de desenvolvimento efetivo, aquele que indica o domínio da criança, demonstrando o que ela já conhece e realiza sozinha. (VYGOTSKY, 1991).

0 complexo trabalho docente em salas multisseriadas, principalmente quando se refere à alfabetização e ao letramento, fica por conta da ausência de formação inicial e contínua dos professores, considerando que nesses espaços são várias as funções assumidas por esses profissionais, implicando a organização do processo pedagógico. Como resultado "esses sujeitos se sentem angustiados e ansiosos ao pretenderem realizar o trabalho da melhor forma possível, visto que se sentem perdidos, necessitando de apoio para organizar o tempo, espaço e conhecimento escolar [...]" (BARROS et al, 2010, p. 28).

\section{METODOLOGIA}

O trabalho se inscreve na Abordagem Qualitativa de Pesquisa (LUDKE; ANDRÉ, 1986; FLICK, 2009; AMADO; 2014; BOGDAN; BIKLEN, 1994), considerando que os métodos qualitativos são relevantes porque possibilitam ao pesquisador envolver-se na vida dos sujeitos, ancorados em ações como ouvir, conversar, permitir a expressão livre dos interlocutores. Isso nos direcionou ao 'Estudo do tipo etnográfico' que, segundo André (1995), é adequado para que o pesquisador realize uma conversão do olhar, no qual tudo o que se verá seja como se nunca tivesse sido visto. Um estudo que requer maior tempo de permanência do pesquisador no campo, sem que se transforme, necessariamente, em um nativo.

Como procedimentos para construção dos dados, utilizamos o Questionário (RICHARDSON et al, 1999), a Entrevista Semiestruturada (LUDKE; ANDRÉ, 1986), a Análise Documental (AMADO, 2014), a Observação Participante (LUDKE; ANDRÉ, 1986; AMADO, 2014; FLICK, 2009) e a Técnica Balanço do Saber (CHARLOT, 2006; DIEB, 2010; ALMEIDA, 2011; ALMEIDA, 2014).

Nosso campo empírico está formado por três escolas municipais rurais, em Espírito Santo/RN. Os sujeitos são três professoras alfabetizadoras que atuam nas turmas multisseriadas do Ciclo de Alfabetização.

Após realizarmos todos os procedimentos para a construção do corpus da pesquisa e da sua validação pelos seus participantes, optamos pela triangulação metodológica dando mais credibilidade ao estudo, cujo princípio é a construção e análise de dados advindos de fontes múltiplas com o intuito de confrontálos e interpretá-los. (FLICK, 2009).

Nesse caminho, para avaliar os conteúdos das fontes trianguladas, nos inspiramos na Análise de Conteúdo (BARDIN, 2010), sem seguir todo o seu rigor, mas norteada por seus princípios, buscando transformar os conteúdos de suas falas em unidades de significação, reorganizando-os, em seguida, em um conjunto de categorias que possibilitou compreender com mais profundidade o objeto de estudo da pesquisa.

Na primeira fase, a pré-análise, realizamos a constituição do corpus documental, formado pelo material construído na pesquisa (transcrições e registros). Na segunda, a análise do corpus documental, após realizarmos inúmeras leituras dos dados, agrupamos aqueles semelhantes, surgindo daí a unidade temática organizada, seguida das respectivas categorias, subcategorias e indicadores, elaborados a posteriori.

Este momento do recorte do corpus exigiu grande atenção e muita paciência para inúmeras e constantes revisões, sempre atentas ao objeto da investigação. Para isso, seguimos as recomendações de Amado (2014) quanto aos critérios de exaustividade; exclusividade mútua; homogeneidade, pertinência; objetividade; produtividade e adequação.

Por último, a fase da interpretação, que consistiu das inferências realizadas a partir das teorias que alicerçam esse estudo. Da análise dos dados, emergiu o tema "Docência em Alfabetização/Letramento na Educação do Campo (EC)"; a categoria "Necessidades da Formação Docente para alfabetizar letrando em Classes Multisseriadas da EC", com três subcategorias "Conteúdos Programáticos Transversais à Alfabetização/Letramento; Conteúdos Programáticos Específicos da Alfabetização/Letramento e Princípios/Procedimentos teórico-metodológicos na Alfabetização/Letramento da EC" - cada uma delas com seus respectivos indicadores de análise. 
Para a elaboração deste artigo, que se configura como um recorte da pesquisa referida, estudamos, apenas, o $1^{\mathrm{a}}$ Indicador da subcategoria "Conteúdos Programáticos Transversais à Alfabetização/Letramento". Para maior clareza do nosso leitor, sublinhamos que o referido Indicador se constituiu de "Documentos Oficiais referentes à EC", quais sejam: LDB 9.394/1996; DCN Educação Básica; DCN Ensino Fundamental de nove anos; DOEBEC; PNAIC/EC; BNCC.

\section{RESULTADOS E DISCUSSÃO}

Para desenvolver uma prática docente na perspectiva de alfabetizar letrando, faz-se necessário que os professores alfabetizadores deem conta dos conteúdos programáticos transversais constituídos como lacunas da formação docente para essa prática. A sua compreensão é necessária, mas não suficiente para que se instale um ambiente favorável nesse contexto. Se o fato de compreender esses conteúdos não garante uma prática exitosa para alfabetizar na perspectiva do letramento, ignorá-los, portanto, "não ensejará uma ação pedagógica bem sucedida", se considerarmos que são inúmeros os fatores que a determinam. (CAMPELO, 2001, p. xx).

Na Tabela 1, apresentamos os conteúdos programáticos transversais à alfabetização/letramento na Educação do Campo que foram referendados pela prática pedagógica das professoras investigadas.

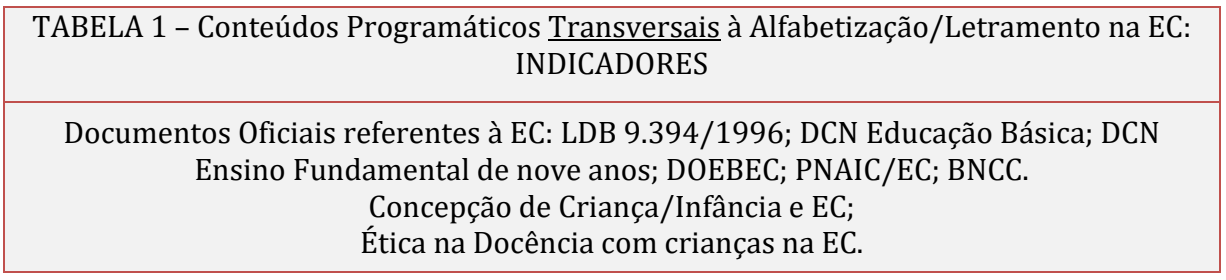

Em se tratando da Educação do Campo, a Lei de Diretrizes e Bases da Educação Nacional, n. 9.394/96, em seu artigo 28, garante que "Na oferta da educação básica para a população rural, os sistemas de ensino promoverão as adaptações necessárias à sua adequação, às peculiaridades da vida rural e de cada região, especialmente". (BRASIL, 1996, p. 11). No entanto, no cenário atual, ainda não visualizamos a inclusão da população rural na condição de protagonista de um projeto social global, considerando que o direito à educação prevalece, cabendo ao poder público garantir o acesso e a permanência bem sucedida dos alunos no ensino obrigatório.

Documentos importantíssimos e ainda pouco conhecidos pelas professoras, as Diretrizes Curriculares Nacionais da Educação Básica (BRASIL, 2013) e as Diretrizes Curriculares Nacionais do Ensino Fundamental de Nove Anos (BRASIL, 2009), trazem em seu bojo orientações para uma prática bem sucedida na alfabetização dos alunos.

Apesar dos avanços e conquistas implementados pelos documentos oficiais que direcionam a Educação do Campo no cenário brasileiro, muitos desafios continuam presentes no contexto das escolas rurais. Dentre eles, o desafio enfrentado pelos docentes quanto à prática de alfabetizar letrando em turmas multisseriadas na busca de uma ação formativa que os "habilite" a desenvolver uma ação pedagógica exitosa.

As pesquisas e até documentos legais (como o Decreto no 8.752, de maio de 2016) têm apontado que os cursos de formação contínua devem estar amparados nas necessidades formativas dos professores, a partir de seu local de trabalho (BRASIL, 2016), pois a eficácia das ações nessa área possui uma relação intrínseca e singular com a análise de necessidades, conforme afirmam Rodrigues e Esteves (1993).

Para compreender melhor como alfabetizar seus alunos na perspectiva do letramento, garantindo-lhes a permanência bem sucedida de que trata a LDB n. 9.394/96 e seguindo as recomendações das DCNEF, as professoras entrevistadas evidenciam a necessidade de conhecer com mais profundidade os documentos oficiais que tratam da Educação do Campo na tentativa de entender com mais clareza as diretrizes e orientações para uma ação pedagógica mais eficaz. Elas sabem que os conhecimentos adquiridos para alfabetizar letrando são imprescindíveis, mas sabem também que apenas estes não dão conta dessa difícil e árdua tarefa - ensinar a ler e a escrever convencionalmente. 
Isso fica evidente na voz da professora A quando diz da necessidade de "Mais conhecimentos do campo com relação a: como é o campo, onde a criança convive, procurar assuntos mais relacionados ao convívio deles".

Esses conhecimentos necessários à prática pedagógica dos quais a professora fala estão claramente inseridos nas orientações das Diretrizes Operacionais da Educação Básica das Escolas do Campo (BRASIL, 2002), que sugerem, dentre outras, a necessidade de construção de uma memória coletiva, que privilegie a luta e o resgate da identidade do campo no sentido de desconstruir a concepção de escola marginalizada, como ainda é vista a escola multisseriada no campo. No entanto, a sua materialização em sala de aula é que se constitui no grande desafio de alfabetizar letrando.

Ao longo das nossas conversas durante as observações realizadas dentro e fora da sala de aula e nas entrevistas muitas eram as dúvidas e as incertezas sobre as práticas que estavam desenvolvendo, se estavam ou não alfabetizando na perspectiva do letramento. Todavia, a preocupação estava centrava em como fazer isso nas turmas multisseriadas, pois havia muito receio em exercer uma ação contrária ao que estava posto nos documentos oficiais, mas havia, também, a firmeza em atuar naquelas turmas, um compromisso assumido por elas com aquelas crianças, considerando as especificidades dessa modalidade de ensino.

As professoras entrevistadas reconhecem as dificuldades e os problemas para atuar nas turmas multisseriadas, mas com elas se identificam porque estão inseridas no contexto rural, vivem e conhecem o cotidiano das crianças, exceto a professora Aurelina que mora no perímetro urbano, mas não abre mão da sua escolha - ser professora de escola rural no contexto multisseriado.

Nesse cenário pouco animador, o complexo trabalho docente em salas multisseriadas, principalmente quando se refere à alfabetização e ao letramento, fica por conta da ausência de formação inicial e contínua dos professores, considerando que nesses espaços são várias as funções assumidas por esses profissionais, implicando a organização do processo pedagógico. Como resultado, "esses sujeitos se sentem angustiados e ansiosos ao pretenderem realizar o trabalho da melhor forma possível, visto que se sentem perdidos, necessitando de apoio para organizar o tempo, espaço e conhecimento escolar [...]", conforme afirma Barros et al (2010, p. 28).

Isso ficou evidente nas vozes das professoras sobre saberes necessários para uma prática exitosa de alfabetizar letrando os alunos que frequentam as turmas multisseriadas no Ciclo de Alfabetização.

Em práticas pedagógicas existentes, o professor alfabetizador ainda desconhece a realidade linguística do aluno do campo, bem como todos os conhecimentos que ele adquire durante sua vida e acaba rotulando-o por não usar a língua padrão.

Ao adotar a concepção de alfabetização na perspectiva do letramento, o Pacto Nacional pela Alfabetização na Idade Certa-PNAIC da Educação do Campo (BRASIL, 2015) concebe que a escola, ao alfabetizar o estudante, não favorece, apenas, a sua apropriação do Sistema de Escrita Alfabética, mas contribui para que ele possa, individual e coletivamente, atuar de forma autônoma em diferentes esferas sociais, produzindo e compreendendo textos de diferentes gêneros, ou seja, agindo por meio desses textos.

Para amenizar esse problema, o PNAIC da Educação do Campo (BRASIL, 2015) define formas de organização do trabalho pedagógico, discutindo sobre as especificidades do espaço escolar do campo e os modos como tais especificidades podem ser consideradas no planejamento da ação didática na alfabetização. Desse modo, a organização da prática pedagógica orientada por projetos didáticos e sequências didáticas é foco de debate, com o intuito de ilustrar como a articulação entre conhecimentos escolares e extraescolares e entre os diferentes componentes curriculares pode ser importante no processo de alfabetização das crianças.

- Compreender a concepção de alfabetização na perspectiva do letramento, a partir do aprofundamento de estudos baseados nas obras pedagógicas do PNBE do Professor e outros textos publicados pelo MEC;

- Refletir sobre o currículo nos anos iniciais do Ensino Fundamental e os direitos de aprendizagem;

- Conhecer os recursos didáticos distribuídos pelo Ministério da Educação e planejar projetos e sequências didáticas em que tais materiais sejam utilizados;

- Analisar projetos didáticos e sequências didáticas para turmas de alfabetização, integrando diferentes componentes curriculares (Língua Portuguesa, Matemática, Ciências, História, Geografia, Arte) e atividades voltadas para o desenvolvimento da oralidade, leitura, escrita e análise linguística. (PNAICBRASIL, 2015, p. 7). 
Ao adotar a concepção de alfabetização na perspectiva do letramento, os autores que integram o PNAIC (BRASIL, 2012) concebem que a escola, ao alfabetizar o estudante, não favorece, apenas, a sua apropriação do Sistema de Escrita Alfabética, mas contribui para que ele possa, individual e coletivamente, atuar de forma autônoma em diferentes esferas sociais, produzindo e compreendendo textos de diferentes gêneros, ou seja, agindo por meio desses textos.

Ainda em conformidade com o PNAIC, para que a alfabetização seja pensada como um processo em que os estudantes do campo possam desenvolver conhecimentos e habilidades para se constituírem como sujeitos coletivos, identificando-se com os anseios das comunidades, é preciso que o planejamento didático considere a construção de um ambiente escolar voltado às práticas políticas e culturais da comunidade.

A necessidade de conhecer mais profundamente os documentos oficiais orientadores para a prática pedagógica exercida na Educação do Campo está presente nas vozes das professoras. Sobretudo na discussão da Base Nacional Comum Curricular (BNCC), evidenciada pela professora AR ao reconhecer "de extrema urgência o estudo deste novo documento para desenvolver de forma mais efetiva a minha prática pedagógica como professora alfabetizadora de crianças do Ciclo de Alfabetização de turmas multisseriadas".

Os fundamentos descritos na introdução da Base Nacional Comum Curricular explicitam as competências a serem desenvolvidas pelos alunos ao longo de sua escolaridade. Na BNCC (BRASIL, 2017), a alfabetização é apresentada como uma questão importante. "[...] nos dois primeiros anos do Ensino Fundamental, a ação pedagógica deve ter como foco a alfabetização", a fim de oferecer amplas oportunidades para que os alunos se apropriem do sistema de escrita alfabética, associando as práticas diversas de letramento.

Nesse novo cenário, o Ciclo de Alfabetização que antes era de três anos, com o novo documento, passa a ser de apenas dois anos, considerando o terceiro ano como limite para o aluno ser alfabetizado. 0 documento traz em seu bojo, na área de Língua Portuguesa, os eixos de integração correspondentes às práticas de linguagem, já sinalizados em outros documentos:

[...] no eixo Oralidade, aprofundam- se o conhecimento e o uso da língua oral, as características de interações discursivas e as estratégias de fala e escuta em intercâmbios orais; no eixo Conhecimentos linguísticos e gramaticais, sistematiza - se a alfabetização, particularmente nos dois primeiros anos, e desenvolvem-se, ao longo dos três anos seguintes, a observação das regularidades da língua e a aprendizagem de regras e processos gramaticais básicos; no eixo Leitura, amplia-se o letramento, por meio da progressiva incorporação de estratégias de leitura em textos de nível de complexidade crescente, assim como no eixo Escrita, pela progressiva incorporação de estratégias de produção de textos de diferentes gêneros textuais; no eixo Educação literária, desenvolve-se a formação do aluno para conhecer e apreciar textos literários, orais e escritos, com textos e livros de crescente grau de literariedade. (BRASIL, 2017, p. 67).

Em conformidade com a BNCC, dentre outras competências, torna-se importante que o aluno diferencie as formas de escrita de outras formas gráficas, que tenha noção das convenções; que escreva de cima para baixo e da esquerda para direita; que compreenda as diferenças entre a fala e a escrita; que conheça o alfabeto para o reconhecimento das letras, suas formas gráficas e sons.

Diante da discussão, fica evidenciada a necessidade da aquisição dos conteúdos transversais para que as professoras investigadas possam alfabetizar seus alunos na perspectiva do letramento. Nesse cenário, compreendemos a formação contínua do profissional docente como o processo de 'formar em serviço' educadores, proporcionando-lhes um espaço de reflexão simultânea entre o que "estou fazendo" e "como posso fazer" - esta mesma ação de uma forma melhor. Assim, consideramos que a formação contínua é um ambiente onde os saberes e as práticas vão sendo ressignificados e recontextualizados, constituindo-se espaço de produção de novos conhecimentos, de troca de diferentes saberes, de repensar e refazer a prática do professor, da construção de novas competências docente.

Nessa perspectiva, recomendam Rodrigues e Esteves (1993) que a análise das necessidades de formação dos professores torna-se imprescindível, considerando a possibilidade de atender às expectativas destes a 
partir das suas vivências em sala de aula e na escola, espaço real onde desenvolvem sua prática profissional.

\section{CONSIDERAÇÕES FINAIS}

Para compreender melhor como alfabetizar seus alunos na perspectiva do letramento, garantindo-lhes a permanência bem sucedida de que trata a LDB n. 9.394/96 (BRASIL, 1996), seguindo as recomendações das DCNEF as professoras evidenciam a necessidade de conhecer com mais profundidade os documentos oficiais que tratam da Educação do Campo na tentativa de entender com mais clareza as diretrizes e orientações para uma ação pedagógica mais eficaz. Elas sabem que os conhecimentos adquiridos para alfabetizar letrando são imprescindíveis, mas sabem também que apenas estes não dão conta dessa difícil e árdua tarefa - ensinar a ler e a escrever convencionalmente.

Nesse sentido, reiteramos que as professoras investigadas nesse estudo têm ciência do seu compromisso com a educação dos alunos, sobretudo quando se trata de ensinar a ler e a escrever. Sabem que precisam entender o contexto no qual suas escolas estão inseridas, que políticas públicas se destinam aos processos de ensinar e de aprender, como deve ser ofertada a Educação do Campo para aqueles que vivem no/do campo, dentre outras especificidades dessa modalidade de ensino.

Além de resultados interessantes para a formação inicial e contínua de professores, nossa pesquisa tem nos permitindo refletir sobre a importância de estudos relativos às necessidades de formação dos professores. Nesse sentido, os resultados preliminares indicam que a análise de necessidades da formação docente poderá ensejar a construção de programas de formação mais significativos e pertinentes, porque sintonizados com necessidades reais dos professores cursistas.

\section{REFERÊNCIAS}

[1] ALBUQUERQUE, E. B. C. de. Conceituando Alfabetização e Letramento. In: SANTOS, C. F.; MENDONÇA, M. (Orgs.) Alfabetização e Letramento: conceitos e relações. Belo Horizonte: Autêntica, 2005, p. 11-21.

[2] ALMEIDA, M. J. P. Análise de Necessidades de Formação: uma Prática Reveladora de Objetivos da Formação Docente. Tese (Doutorado em Educação). Programa de Pós-Graduação em Educação da UFRN. Natal: UFRN, 2014.

[3] ALMEIDA, L. R. R. O saber e o aprender de professores da Educação de Jovens e Adultos de Assú, Rio Grande do Norte. Tese (Doutorado em Educação). Programa de Pós-Graduação em Educação da UFRN. Natal: UFRN, 2011.

[4] AMADO, J. Revista de Educação e Formação em Enfermagem (ESE-A.F). no 5, 2000, pp.53-63.

[5] ANDRÉ, M. E. D. A. de. Etnografia da prática escolar. Campinas: Papirus, 1995.

[6] ANTUNES-ROCHA, I.; HAGE, S. M. (Org.). Escola de Direito: reinventando a escola multisseriada. Belo Horizonte: Autêntica Editora, 2010.

[7] ARroyo, M. G; CALDART, R. S.; MOLiNA, M. C. (org.) Por uma educação do campo. Petrópolis, RJ: Vozes, 2004.

[8] AZEVEDo, M. A. de; QUEIROZ, M. A. de. Políticas de educação (a partir dos anos 1990) e trabalho docente em escolas do campo multisseriadas: experiência em munícipio do Rio Grande do Norte. In: ANTUNES-ROCHA, M. I.; HAGE, S. M. (org.). Escola de direito: reinventando a escola multisseriada. Belo Horizonte: Autêntica Editora, 2010. p. 61-72.

[9] BARDIN, L. Análise de conteúdo. Lisboa: Edições 70, 2010.

[10] BARROS, O. F. et al. Retratos de Realidade das Escolas do Campo: multissérie, precarização, diversidade e perspectivas. In: ANTUNES-ROCHA, I.; HAGE, S. M. (Org.). Escola de Direito: reinventando a escola multisseriada. Belo Horizonte: Autêntica Editora, 2010.p. 25-33.

[11] BOGDAN, R.; BIKLEN, S. K. Investigação Qualitativa em Educação: uma introdução à teoria e aos métodos. Porto: Porto, 1994.

[12] BRASIL. Ministério da Educação. Lei de Diretrizes e Bases da educação Nacional no 9.394/96, em 17 de dezembro de 1996. Brasília: MEC/SEF, 1996.

[13] _. Diretrizes Operacionais para a Educação Básica nas Escolas do Campo. Resolução CNE/CEB No 01/2002. Brasília: MEC, SEB, 2002.

[14] _. Conselho Nacional de Educação. Diretrizes Curriculares Nacionais Gerais da Educação Básica. Diretoria de Currículos e Educação Integral. Brasília: MEC, SEB, DICEI, 2013. 
[15] _. Secretaria de Educação Básica. Diretoria de Apoio à Gestão Educacional. Pacto Nacional pela Alfabetização na Idade Certa: projetos didáticos e sequências didáticas na educação do campo: a alfabetização nas diferentes áreas de conhecimento escolar: educação do campo: unidade 06. Brasília: MEC, SEB, 2015.

[16] _. Decreto no 8.752, de 9 de maio de 2016. Política Nacional de Formação de Profissionais da Educação Básica. Brasília: MEC, SEB, 2016.

[17] __. Resolução n. 02/2017. Base Nacional Comum Curricular. Brasília: MEC, SEB, 2017.

[18] CAGLIARI, L. C. Alfabetização e lingüística. 10 ed. São Paulo: Scipione, 2001.

[19] CALDART, R. S. Sobre Educação do Campo. In: SANTOS, C. A. dos (Org.). Educação do Campo: campo, políticas públicas, educação. Brasília: INCRA; MDA, 2008. p. 67-86.

[20] CAMPELO, M. E. C. H. Alfabetizar crianças: um ofício, múltiplos saberes. Tese (Doutorado em Educação) Natal, 2001, 257 p. Centro de Ciências Sociais Aplicadas, Universidade Federal do Rio Grande do Norte. Natal: UFRN, 2001.

[21] CARVALHO, M. Alfabetizar e letrar: um diálogo entre a teoria e a prática. Petrópolis, RJ. Vozes, 2005.

[22] CHARLOT, B. A pesquisa educacional entre conhecimentos, políticas e práticas: especificidades e desafios de uma área de saber. Revista Brasileira de Educação, s/l, v. 11, n. 31, p. 07-18, jan./abr. 2006.

[23] D'AGOSTINI, A.; TAFFAREL, C. N. Z.; SANTOS JÚNIOR, C. L. Escola Ativa. In: CALDART, R. S.; PEREIRA, I. B.; ALENTEJANO, P.; FRIGOTTO, G. (Org.). Dicionário da Educação do Campo. São Paulo: Expressão Popular, 2012. p. 313324.

[24] DIEB, M. H. Móbeis, sentidos e saberes: o professor da Educação Infantil e sua relação como saber. Tese (Doutorado em Educação). Universidade Federal do Ceará, Faculdade de Educação, Fortaleza, 2007.

[25] FERNANDES, B. M. et al. Primeira Conferência Nacional por uma Educação Básica do Campo. In: ARROYO, M. G.; CALDART, R. S.; MOLINA, M. C. Por uma educação do campo. Petrópolis: Vozes, 2004. p. 19-62.

[26] FLICK, U. Uma introdução à pesquisa qualitativa. São Paulo: Bookman, 2009.

[27] GHEDIN, E.; ALMEIDA, M. I. de; LEITE, Y. U. F. Formação de professores: caminhos e descaminhos da prática. Brasília: Líder Livro, 2008.

[28] LEITE, S. A. da S. Alfabetização e Letramento: contribuições para as práticas pedagógicas. Campinas: Komedi, 2001.

[29] _. O processo de alfabetização escolar: revendo algumas questões. Perspectiva. Florianópolis, v.24, n.2, p.449-474, jul/dez. 2006.

[30] LUDKE, M.; ANDRÉ, M. E. D. A. Pesquisa em Educação: abordagens qualitativas. São Paulo: EPU, 1986.

[31] MACIEL, F. I. P. Ser alfabetizado, estar alfabetizado: eis a questão. In: BRASIL. Ministério da Educação. Secretaria de Educação a Distância. Cadernos da TV Escola. Brasília, MEC/SED, 1999, p.17-25.

[32] MOLINA, M. C. Educação Popular e Movimentos Sociais: tensões e desafios para a América Latina. In: REUNIÃO ANUAL DA ANPED, 32, 2009, Caxambu. Anais... Caxambu, 2009.

[33] MORTATTI, M. do R. L. Educação e letramento. 2. ed. São Paulo: Editora UNESP, 2004.

[34] RICHARDSON, R. J. et al. Pesquisa social: métodos e técnicas. 3. Ed. São Paulo: Atlas, 1999.

[35] RODRIGUES, M. A. P.; ESTEVES, M. A análise de necessidades na formação de professores. Porto: Porto Editora, 1993.

[36] RODRIGUES, M. A. P. A análise de práticas e de necessidades de formação. Lisboa, 2006.

[37] SOARES, M. B. Letramento e Alfabetização. In: RIBEIRO, V. M. (org.) Letramento no Brasil. Reflexões a partir do INAF 2001. São Paulo: Global, 2003.

[38] __. Letramento: um tema em três gêneros. 2 ed. Belo Horizonte: Autêntica, 2000.

[39] VIEIRA, G. B. Alfabetizar Letrando: Investigação-ação fundada nas necessidades de formação docente. Tese (Doutorado em Educação). Programa de Pós-Graduação em Educação da UFRN. Natal: UFRN, 2010.

[40] VYGOTSKY, L. S. Aprendizagem e Desenvolvimento Intelectual na Idade Escolar. In: VIGOTSKI, L. S.; LURIA, A. R.; LEONTIEV, A. N. Linguagem, Desenvolvimento e Aprendizagem. São Paulo: Ícone, 1991. p. 80-97. 


\section{Capítulo 16}

\section{Formação de professores e trabalho docente no ensino médio: Uma análise dos trabalhos da ANPED ${ }_{10}$}

\section{Néryla Vayne Alves Dias}

Patrícia Regina de Souza

Renata Portela Rinaldi

Resumo: Apresentamos neste trabalho uma análise bibliográfica sobre o tema da formação de professores e do trabalho docente no ensino médio, a partir das produções da Associação Nacional de Pós-Graduação e Pesquisa em Educação (ANPED), no período de 2000 a 2016. 0 objetivo foi compreender o que tem sido produzido no campo da formação de professores e do trabalho docente neste nível de ensino. Os descritores que orientaram o levantamento bibliográfico foram: trabalho docente, formação docente, formação de professores, desenvolvimento profissional, educação básica, ensino médio e nível médio. Após uma criteriosa seleção encontramos 20 trabalhos completos que investigaram a temática. Elencamos os trabalhos em 6 categorias de análise: identidade docente, cursos de formação continuada, trabalhos teóricos, trabalhos do tipo estado da arte, professor do ensino médio e epistemologia da prática profissional. Nossas análises, evidenciamos a escassez de pesquisas sobre a temática neste nível de ensino considerando a periodicidade do evento e a quantidade de publicações nele apresentadas. As produções analisadas mostraram-se pontuais, como resultados de teses e dissertações e pesquisas individuais sem grande representatividade de grupos de pesquisas que consideram a temática e a investigam nos diferentes aspectos. A categoria mais representativa pelo número de trabalhos foi "cursos de formação continuada", reforçando a ideia de que a academia permanece na oferta e análise de cursos pontuais de capacitação, além disso, a reflexão acerca do trabalho docente do professor do ensino médio quase não comparece no universo das pesquisas. De um modo geral, apontamos que a área necessita de pesquisas aprofundadas, que tenham impacto real na formação do professor do ensino médio, por exemplo, parcerias entre universidade-escola que contribuam para o desenvolvimento de trabalhos coletivos e colaborativos visando o enfrentamento dos desafios contemporâneos nesse nível de ensino.

Palavras-chave: Formação de professores. Trabalho docente. Ensino médio. Pesquisa bibliográfica.

10 Texto apresentado e publicado nos Anais do|XIV EDUCERE - Congresso Nacional de Educação. 


\section{INTRODUÇÃO}

A formação e o desenvolvimento profissional tem sido alvo de inúmeras pesquisas no campo da formação de professores. Atualmente as investigações têm considerado a necessidade de dar voz aos docentes e conhecer de modo profundo o seu fazer em sala de aula. Porém, é preciso ir além, como ressalta André (2010), é necessário considerar o contexto em que o professor se insere e no qual ocorrem as práticas, já que esses são caminhos efetivos para alcançar um ensino de qualidade, o que envolve a necessidade de um trabalho colaborativo entre pesquisadores da universidade e professores das escolas.

Cunha (2013) aponta que as pesquisas sobre o professor e sua formação assumiram, ao longo da história, posições políticas e epistemológicas que definiram a formação do professor ao longo desta trajetória. A autora ressalta que o professor e seu contexto de trabalho estão intimamente ligados e não podem ser pensados separadamente. Porém, é possível evidenciar que ao longo da história ora as pesquisas focavam o olhar sobre o ensino e a escola e ora sobre o professor.

Diniz-Pereira (2013) ressalta que, a partir de 1980, houve um aumento significativo no número de trabalhos sobre formação de professores e os educadores passaram a ser o centro das investigações com foco principalmente na subjetividade e identidade docente. Nos EUA, nas décadas de 1980/1990 os estudos focalizaram o aprender a ensinar. Já no Brasil, a identidade e profissionalização docente começaram a serem temas frequentes no fim da década de 1990, não sendo muito exploradas anteriormente.

Ainda conforme Diniz-Pereira (2013) é possível identificar que nos trabalhos apresentados nas Reuniões da Associação Nacional de Pós-Graduação e Pesquisa em Educação (ANPED), as temáticas de identidade e profissionalização docente começaram a ganhar destaque e ser prioridade na década de 1990. Outras temáticas que começam a aparecer relacionadas à formação docente são as identidades culturais e étnicas e as identidades profissionais no campo do trabalho. Contudo, destaca que o número de pesquisas que focalizam a identidade docente é ainda muito pequeno.

Nessa perspectiva, apresentaremos os resultados de investigação e sistematização de um banco de dados sobre formação de professores e trabalho docente no Ensino Médio, no período de 2000-2016, centrandonos na análise dos artigos completos encontrados nos Grupos de Trabalho (GT) da ANPED. Tal atividade se constitui como parte integrante de uma disciplina do Programa de Pós-Graduação em Educação da FCT/UNESP, intitulada "Formação de professores: dimensão histórica, cognitiva, ética, afetiva e de desempenho" que prevê a criação de um banco de dados sobre Formação de professores e Trabalho docente nos diferentes níveis e modalidades de ensino, a saber: Educação infantil, Ensino fundamental, Ensino médio, Ensino superior, Educação profissionalizante e Educação à distância.

Dessa forma, objetivamos, neste artigo, compreender o que tem sido produzido no campo da formação de professores e trabalho docente no Ensino médio. Buscaremos analisar e discutir a frequência com que foram publicados artigos e quais as temáticas recorrentes relativas ao objeto de estudo nas bases de dados da ANPED, no período de 2000 a 2016. Tal reflexão surge como um exercício inicial da investigação e sistematização do levantamento bibliográfico, o qual ainda está em andamento.

\section{REFERENCIAL TEÓRICO}

\subsection{O CAMPO DA FORMAÇÃO DE PROFESSORES}

Conforme Marli André (2010), até a década de 90 a temática sobre formação docente não era alvo de muitas pesquisas. Tanto que ao analisar as publicações do ENDIPE (Encontro Nacional de Didática e Prática de Ensino), a autora evidencia que por muito tempo a temática de formação docente esteve incluída no campo da didática.

Entretanto, André (2010) aponta que atualmente, a formação de professores já se constituiu como um campo autônomo de estudos e tem crescido cada vez mais o interesse por parte dos pesquisadores, tanto acerca da formação de professores como quanto em relação ao trabalho docente, algo que pode ser evidenciado por meio de pesquisas e de eventos científicos que se debruçam sobre essa área.

Nessa perspectiva, Diniz-Pereira (2013) afirma que a formação de professores é um campo novo. 0 marco de seu surgimento se deu em 1973 com a publicação da revisão de literatura especializada, consolidandose em 1986 com uma nova revisão de literatura sobre o campo de pesquisa.

Conforme André (2010) existem alguns aspectos que delimitam o campo da formação docente como um campo próprio de estudos, quais sejam: 
- Ter um objeto próprio de pesquisa: Frutíferas discussões se consolidam acerca do objeto de pesquisa, porém os pesquisadores convergem no sentido de determinar o Desenvolvimento Profissional Docente (DPD) como o objeto de estudo da formação de professores.

Vale destacar que, conforme Vaillant e Marcelo (2012) existem muitos termos que se referem aos processos de aprendizagem pelos quais os docentes passam ao longo da vida. Os autores, ao abordar sobre tais processos, utilizam o termo Desenvolvimento Profissional Docente (DPD) que corresponde a outros termos (formação permanente, formação contínua, formação em serviço, desenvolvimento de recursos humanos, aprendizagem ao longo da vida, reciclagem ou capacitação) que frequentemente são utilizados. Para os autores, o desenvolvimento profissional docente é um processo sem fim, já que tem início na formação inicial e perpassa todos os processos de aprendizagem pelos quais os docentes passam.

- Metodologia dos estudos: quanto às metodologias sobre formação docente, André (2010) enfatiza que estas têm se constituído como metodologias próprias: depoimentos escritos e orais e histórias de vida; pesquisas colaborativas e pesquisa-ação. Ou seja, são metodologias com caminhos próprios.

- Criação de um grupo de cientistas com códigos e interesses comuns: Marli André (2010) aponta que a formação docente vem agregando grupos de pesquisadores em eventos, publicações e fóruns de debates (criação do GT- Formação de Professores na ANPED; I Encontro de grupos de pesquisa sobre formação de professores (2006); Revista Brasileira de Pesquisa sobre Formação de Professores).

- Incorporação ativa dos participantes na pesquisa: André (2010) esclarece que tem havido uma incorporação ativa dos próprios protagonistas nas pesquisas, além das devolutivas, da participação conjunta; pesquisa-ação e pesquisa colaborativa que contribuem nesse sentido; bem como a existência de projetos (Projeto Universidade-escola/FAPESP) que visam aproximar os pesquisadores e os pesquisados.

- Reconhecimento do papel fundamental da formação docente: em relação a esse aspecto, André (2010) afirma ser indiscutível que a temática da formação docente tem recebido grande atenção de políticos, administradores e investigadores. Podem ser destacadas as matérias em jornais e revistas, bem como os depoimentos políticos em virtude da preocupação centrada no papel da formação docente na qualidade da educação.

Dessa maneira, após abordar cada uma das características de um campo de estudos e inserir a formação docente nesses critérios, Marli André (2010) explicita que a formação de professores pode ser considerada como um campo próprio, uma vez que contempla todas as características necessárias a essa delimitação.

Nesse sentido, é importante considerar que nenhum campo é neutro e que a formação de professores é "[...] um campo de lutas e interesses em que se estabelecem relações de força e de poder e, por isso mesmo, dinâmico, movediço e inconstante" (DINIZ-PEREIRA, 2013, p. 146).

\subsection{FORMAÇÃO DE PROFESSORES E O TRABALHO DOCENTE}

Conforme o entendimento de Estevão, citado por Cunha (2013), a formação é uma prática social específica com funções sociais que celebra determinados valores. Ou seja, há que se considerar que a formação não é neutra.

É consenso entre muitos os autores (BELINTANE, 2002; IMBERNÓN, 2010; NÓVOA, 2009; NEZ; ZANOTTO, 2006; FUSARI; FRANCO, 2005) que a formação constante na profissão professor é um pilar central de seu trabalho, uma vez que as transformações da sociedade o levam à necessidade de estar sempre buscando um aprimoramento que subsidie suas práticas em sala de aula de modo a contribuir com a melhoria na qualidade educativa.

Muitos estudiosos (BRANCO, BRANCO, PETRILLI, 2010; SOUZA, 2012; VOGT, 2012) defendem que a formação continuada dos docentes deve ser centrada na realidade escolar e dão destaque ao HTPC (Horas de Trabalho Pedagógico Coletivo) como um espaço que pode ser muito significativo no que se refere à formação continuada e produção de saberes docentes para que os professores possam suprir as demandas que lhes são impostas cotidianamente. Para Souza (2012) os HTPCs são possibilidades para a formação continuada de docentes. Contudo, há muitas reflexões que demonstram as falhas que têm ocorrido e que tem impossibilitado que o HTPC seja considerado (e concretizado) como um espaço de formação.

No que se refere à formação, Vaillant e Marcelo (2012) acreditam que a autoformação é a chave. Eles relatam que este é o principal aspecto para que a formação não seja fadada ao fracasso, de nada adianta querer convencer o outro da sua necessidade de formação sem haver um comprometimento pessoal e 
profissional por parte do aprendiz. Para os autores, é fundamental que todas as pessoas, principalmente os docentes, desenvolvam essa capacidade de autoformação, assumam o seu próprio desenvolvimento, delineando procedimentos e técnicas necessárias para que o processo de aprendizagem ocorra. Nessa perspectiva, os autores enfatizam a importância da autonomia do sujeito adulto para aprender.

Perrenoud (2000) enfatiza a necessidade de dez novas competências necessárias aos docentes, quais sejam: organizar e dirigir situações de aprendizagem; administrar a progressão das aprendizagens; conceber e fazer evoluir os dispositivos de diferenciação; envolver os alunos em suas aprendizagens e em seu trabalho; trabalhar em equipe; participar da administração da escola; informar e envolver os pais; utilizar novas tecnologias; enfrentar os deveres e os dilemas éticos da profissão e administrar a sua própria formação contínua, a qual merece destaque, uma vez que ela condiciona o desenvolvimento e a atualização de todas as outras. Vale ressaltar que esta última vai ao encontro do que Vaillant e Marcelo (2012) definem como autoformação.

A autoformação se estabelece como algo fundamental no que se refere à melhoria da prática do professor, uma vez que os aspectos que permeiam tal prática são a criticidade e a reflexão sobre o trabalho docente. Essa postura se estabelece como algo fundamental, uma vez que o professor tem a capacidade de buscar aperfeiçoamento em um aspecto que realmente necessite, diferentemente de quando participa de formações advindas de políticas públicas, as quais, muitas vezes, são uniformes e não levam em consideração as necessidades formativas próprias de cada realidade de sala de aula.

São inúmeros os autores (SCHÖN, 1992; DE PAULA, 2009; ZEICHNER, 1993; ALARCÃO, 1996; HYPOLITTO, 1999) que partilham da posição de que atualmente se faz necessário que o professor atue como um profissional crítico e reflexivo e, que, a partir de tais características, saiba atuar sobre o seu contexto de trabalho, superando os desafios e solucionando possíveis problemas que surjam em sua prática cotidiana.

Nesse sentido, existem muitos desafios impostos aos docentes e, consequentemente, a necessidade de mais pesquisas sobre formação que contemplem novas temáticas que abordem toda a complexidade da área. Vale destacar que conforme André (2010) os estudos necessitam contemplar múltiplas dimensões e enfoques e uma variedade de temáticas porque existem temas (condições de trabalho, dimensão política da formação etc.) que estão sendo silenciados nas pesquisas. Dessa maneira, conforme é ressaltado por Cunha (2013), o campo de formação de professores apresenta-se como um tema inesgotável, além disso, enfatiza que sempre haverá desafios no campo da formação porque esta se modifica em virtude dos desafios e das mudanças advindas do tempo e do espaço em que a sociedade se situa.

Além da preocupação em compreender os processos de formação do professor, alguns autores investigam o trabalho docente, que diz respeito às tarefas relacionadas à profissão, ao seu fazer, ao seu espaço de trabalho e às intensas relações que ali se travam. Nesse sentido, existem autores (LOPES, 2001; LAPO; BUENO, 2003) que apontam que o ambiente de trabalho docente, reconhecido como complexo e imprevisível, impõem ao professor uma série de "obrigações", atividades e relações que muitas vezes podem desencadear o mal-estar docente. 0 mal-estar docente pode ser entendido como o ápice do esgotamento profissional, relacionado a fatores emocionais e que podem implicar no abandono da carreira.

Diante do que fora mencionado anteriormente, outros autores (JESUS, 2002; REBOLO; BUENO, 2014) acrescentam que a forma como o professor lida com os fatores de ordem objetiva, por exemplo: relações interpessoais com alunos, direção, coordenação, pais e comunidade; ampla diversidade de tarefas e atribuições; condições precárias de trabalho; baixos salários; falta de apoio das políticas públicas para modificação desse cenário; e de ordem subjetiva, relacionada às características pessoais do professor, como: habilidades, competências, valores e crenças, etc. podem gerar situação de mal-estar, ou quando ele reconhece a dimensão do problema e estabelece situações de enfretamento desses problemas podem gerar situações de bem-estar. Esse cenário de precarização do trabalho docente, o qual se tem conhecimento no nosso país, acompanha o desenvolvimento do Capitalismo e das políticas neoliberais em contexto nacional. Desse modo, tais aspectos também devem ser considerados tanto nas políticas de formação inicial e continuada como nas pesquisas relacionadas à temática.

\section{METODOLOGIA}

Esse estudo caracteriza-se com uma pesquisa de natureza bibliográfica, no qual utilizamos como estratégia de coleta de dados o levantamento bibliográfico de artigos científicos e trabalhos completos publicados em eventos nacionais com foco na abordagem da formação de professores e do trabalho docente considerando o nível do Ensino Médio. 
Para o levantamento e a sistematização do banco de dados sobre o campo de estudo foram delimitadas seis bases de dados on-line: Encontro Nacional de Didática e Prática de Ensino (ENDIPE), Associação Nacional de Pós-Graduação e Pesquisa em Educação (ANPED), Associação Nacional de Política e Administração da Educação (ANPAE), Biblioteca Digital Brasileira de Teses e Dissertações (BDTD), Revista Brasileira de Educação (RBE) e Caderno CEDES.

As buscas foram realizadas com o uso de diferentes palavras-chave: trabalho docente, formação docente, formação de professores, desenvolvimento profissional, educação básica, ensino médio e nível médio. Os trabalhos foram delimitados com base nas temáticas de formação de professores e trabalho docente no Ensino Médio e a partir de um recorte temporal de 16 anos, ou seja, priorizamos as publicações no período de 2000 a $2016^{11 .}$.

A investigação ainda se encontra em andamento, pois pretendemos concluir esse trabalho ao término da disciplina cursada. Nesse sentido, apresentamos, no presente artigo, um recorte dessa sistematização em que objetivamos analisar e discutir a respeito dos trabalhos encontrados na ANPED no período delimitado (2000 a 2016). Nessa base de dados, a organização do levantamento bibliográfico foi realizada por Grupos de Trabalho (GT) e foram encontrados 20 artigos.

É importante ressaltar que as produções de todos os GTs foram consultadas, mas os trabalhos sobre formação e trabalho docente foram encontrados apenas nos GT 4 (Didática) e GT 8 (Formação de Professores), respectivamente.

Os dados foram analisados levando-se em consideração a quantidade de trabalhos publicados no período ora delimitado e a recorrência das temáticas considerando o foco do estudo. Para a discussão e análise dos dados, nos pautamos em autores que tratam a respeito de formação de professores e trabalho docente a partir dos elementos que orientam a análise de conteúdo. Mais especificamente, a análise dos dados foi realizada a partir da criação de categorias que objetivaram responder: Quais os problemas de pesquisas encontrados? Quais os objetivos propostos? Quem são os autores e qual a vinculação institucional? Quais as principais metodologias utilizadas? Quais os principais referenciais teóricos que orientaram a investigação? Em que direções apontam seus resultados?

As respostas a estas questões nos permitiram delinear um panorama da área, evidenciando as temáticas recorrentes; as técnicas e análises de dados mais utilizadas; como essa produção caminhou ao longo do tempo, em que momento foi mais ou menos investigada; quais os referenciais mais utilizados. Estes dados nos permitem fazer inferências e proposições a respeito deste campo de pesquisa, apresentando as possíveis lacunas e os caminhos mais trilhados. Tendo essas perspectivas como premissas que apresentamos nossos dados a seguir.

\section{RESULTADOS E DISCUSSÃO}

Como acima descrevemos, nosso trabalho buscou compreender como está sendo tratada pelas pesquisas a temática da formação de professores e o trabalho docente no Ensino Médio publicados nas Reuniões Anuais da ANPED. Definindo formação de professores como: o espaço de formação inicial, continuada, desenvolvimento profissional e autoformação, e o trabalho docente como as inúmeras atividades que envolvem o fazer do professor.

O recorte do nível de ensino demonstra algumas de suas particularidades. A primeira, é que é responsável por uma formação de múltiplas áreas do conhecimento: Língua portuguesa, Matemática, História, Geografia, Biologia, Física, Química, Sociologia, Filosofia, Arte e Educação física. A segunda advém da relação com o ensino médio técnico e com o mundo do trabalho. Estes foram fatores marcantes e que restringiram o número de trabalhos considerados para a pesquisa.

Inicialmente, consideramos todos os trabalhos dos GTs da base de dados da ANPED no período de 2000 a 2016, a partir das palavras-chaves supramencionadas. Desse levantamento resultaram 132 trabalhos que foram lidos e refinados novamente com o foco na formação do professor e trabalho docente no Ensino Médio. Tratando especificamente desta temática, encontramos 20 trabalhos agrupados em dois GTs: 2 trabalhos apresentados no GT da Didática e 18 trabalhos apresentados no GT de Formação de Professores.

Dentre os trabalhos que versam sobre o nível médio, encontramos diversos que investigaram as seguintes temáticas: o impacto das políticas públicas no desenvolvimento deste nível de ensino na Educação Básica;

11 Os anos pesquisados foram: 2000, 2001, 2002, 2003, 2004, 2005, 2006, 2007, 2008, 2009, 2010, 2011, 2012, 2013, 2015. Isso porque os eventos da ANPED eram anuais e a partir de 2013 passaram a ocorrer a cada dois anos. 
que tratam do ensino técnico; que relacionam o jovem, a formação do nível médio e o mundo do trabalho; que envolvem questões sociais; e tratavam de situações de ensino-aprendizagem com os alunos do ensino médio, sejam em disciplinas específicas ou envolvendo as tecnologias. Entretanto, todas estas temáticas extrapolam nosso objeto de estudo que se volta para a formação do professor e o trabalho docente que leciona para o Ensino Médio.

Nesse contexto, tivemos a seguinte ocorrência de publicações ao longo dos anos:

Tabela 1 - Formação de professores e trabalho docente no ensino médio a partir das publicações da ANPED do período de 2000-2016

\begin{tabular}{|c|c|c|}
\hline Anos do Evento & $\begin{array}{c}\text { Quantidade de trabalhos } \\
\text { publicados por ano }\end{array}$ & $\begin{array}{c}\text { Total de Artigos } \\
\text { Publicados }\end{array}$ \\
\hline $2000,2007,2009$ & 3 & 9 \\
\hline $2001,2002,2003,2004,2006$ & 2 & 10 \\
\hline 2008 & 1 & 0 \\
\hline $2005,2010,2011,2012,2013,2015$ & 0 & 20 \\
\hline TOTAL & & 1 \\
\hline
\end{tabular}

Fonte: Dados organizados pelas autoras, com base no levantamento bibliográfico.

A primeira análise que fizemos foi referente aos períodos de publicações dos anos 2000 a 2009 . Observamos que houve publicações anuais envolvendo a temática, com exceção do ano de 2005 no qual não foi encontrado nenhum artigo sobre nosso tema. A partir de 2010 não encontramos mais nenhum trabalho que tratasse com primazia a formação dos professores no nível médio. Esses resultados podem nos indicar a consolidação dos grupos de pesquisas e das publicações em eventos específicos das áreas do conhecimento, já que como apontamos anteriormente, o ensino médio apresenta características distintas da Educação Infantil e do Ensino Fundamental, tendo em vista que é formada pelo professor especialista das diferentes áreas do conhecimento.

Outro aspecto que nos chamou a atenção refere-se à organização metodológica dos trabalhos no início dos anos 2000, estes não apresentaram com profunda clareza os problemas de pesquisa, objetivos, metodologia e os resultados da investigação; apresentavam-se mais como relatos de experiência. Nossa constatação vai ao encontro da pesquisa de levantamento bibliográfico realizada por André (2010), na qual a autora constatou que em diversas pesquisas, mesmo em teses e dissertações, falta clareza dos aspectos tanto teóricos como metodológicos, afirmando que esse rigor é uma exigência primária nas pesquisas acadêmicas para que contribuam com investigações consistentes para o campo da pesquisa.

Considerando as metodologias e seus respectivos encaminhamentos nas pesquisas, observamos o predomínio de pesquisas qualitativas, utilizando como procedimentos metodológicos principalmente: história oral, história de vida, narrativas de vida, pesquisa-ação. Para a captação dos dados os principais instrumentos foram: entrevistas semiestruturadas, grupos focais, questionários, observação e leitura e seleção de material escrito. As análises concentram-se em análise de conteúdo proposta por Bardin, e análise do discurso na perspectiva de Bakhtin, alguns trabalhos não especificam a forma como foram categorizados os dados. Entre os referenciais teóricos, encontramos nos primeiros trabalhos uma predominância de autores estrangeiros que investigam a formação docente a partir da construção da identidade, da reflexão sobre a prática, reflexão sobre a ação, autonomia profissional, desenvolvimento profissional. Os principais autores citados foram: Gauthier; Shulman; Nóvoa; Sacristan; Therrien; Zabala; Polanyi; Carr e Kemmis; Schon; Sacristan; Contreras; Giroux; Esteve; Perrenoud, Zeichner, Dewey, Eliot; Charlot; Tardif; Marcelo Garcia. No decorrer das pesquisas aparecem também autores brasileiros como: Pimenta, André, Pereira, Gatti, Carvalho, Freire, Fazenda e Cunha. Uma análise a partir desses aspectos corrobora também com a consolidação do campo da pesquisa no âmbito da formação de professores no Brasil, em que pesquisadores brasileiros a partir de suas pesquisas voltadas para o contexto nacional tornaram-se referência no assunto. Esses dados estão em consonância com os apontados por André (2010) e Diniz-Pereira (2013) tratando da consolidação do campo da formação de professores no Brasil. 
Não encontramos hegemonia em grupos de pesquisa. Os trabalhos encontrados eram de autores diversos, ficando nítido que a temática não é recorrente a um grupo ou uma universidade em destaque. Este fator chama a atenção, pois de um modo geral a temática parece fazer parte de iniciativas individuais, pesquisas de mestrado ou doutorado e não estudos com grupos de pesquisas consolidados e que a representam, oportunizando parcerias de trabalhos, entre escola e universidade e entre áreas interdisciplinares por exemplo.

0 dado citado anteriormente aponta em direção oposta às ideias de Diniz-Pereira (2003) que apoiado por Zeichner, defende a formação de professores multidisciplinar e multi-metodológica, característica da formação oportunizada pelo nível médio, que antes de contribuir para uma formação integral do aluno, mantem-se desarticulada e descontextualizada. Isto também corrobora com o que André (2010) enfatiza ao afirmar que, mesmo com o grande número de pesquisas acadêmicas, a educação e a sala de aula permanecem estagnadas. Entendemos que o estabelecimento de parcerias em que oportunizam um espaço de formação e discussão é sem dúvida um espaço propício para a compreensão das complexidades envolvidas naquele universo e a discussão de possibilidades de superação dos problemas ali enfrentados. Já pesquisas pontuais, que visam apenas coleta de dados, pouco contribuem para a modificação da realidade e esta tem sido uma das críticas aos trabalhos da pós-graduação em educação e/ou ensino, apontadas por autores como Diniz-Pererira (2013) e André (2010).

Em relação às temáticas, classificamos os trabalhos em:

1) Identidade docente: que compete a construção da identidade docente e os processos identitários. Os trabalhos de Freitas et al. (2000), Azambuja; Oliveira (2000) e Gentil, (2006) apresentam como objeto de pesquisa a construção da identidade docente e as reflexões sobre a temática. Nestes trabalhos, os autores trazem como resultados a importância da formação inicial, da relação de saberes formais e informais, as trajetórias profissionais, a cultura e as lutas travadas no seu contexto e a partir de suas experiências. Todos estes fatores são elencados como essenciais para o processo de construção da identidade docente. Cabe ressaltar que essas pesquisas não destacaram o perfil ou a importância da formação do professor do nível médio, mas trabalharam com professores ou curso de formação inicial responsável por este nível de ensino.

2) Cursos de Formação Continuada: compreendem os trabalhos que analisaram propostas e programas, tais como cursos de formação continuada, cursos de capacitação para os docentes que lecionam no Ensino Médio. Os trabalhos de Almeida; Villani (2000), Tristão (2001), Garcia (2002), Santos (2003), Xavier (2007), Correia, Bonifácio e Nunes (2007), Melo (2007) apresentam resultados de trabalhos envolvendo cursos de formação continuada ou capacitação. Novamente aparece a diversidade natural do nível de ensino investigado, sendo que as temáticas das pesquisas foram diversas, entre as quais: educação ambiental, interdisciplinaridade, tecnologias, práticas reflexivas, desenvolvimento da autonomia profissional, coordenadores pedagógicos e a sua formação. Nos resultados os autores apresentam, de um modo geral, a visão positiva dos cursos de formação continuada e capacitação, afirmando ser uma possibilidade para o desenvolvimento profissional. Destacamos o trabalho de Santos (2003) que analisa programas de formação continuada desenvolvidos por Universidades no Rio de Janeiro, a autora afirma que estes programas se mostram insuficientes para o desenvolvimento da autonomia profissional, por isso considera como iniciativas frágeis da universidade e pouco alteram a realidade ou as concepções dos docentes. Nesta categoria os trabalhos também não destacam as especificidades da formação do docente de nível médio.

3) Trabalhos teóricos: aqui se encontram os trabalhos que apresentaram reflexões teóricas sobre a temática, sem a participação de sujeitos. 0 trabalho de Vaz, Mendes e Maués (2001) apresenta um trabalho teórico sobre as metodologias de narrativas para compreender os processos de formação de professores; já Jordão (2003) apresenta a pesquisa-ação como importante estratégia para a formação de professores; e Pereira (2009) apresenta reflexões acerca das propostas de formação e a sua interferência na realidade da sala de aula. Todos os trabalhos apresentam resultados gerais, tanto para a formação de professores do nível médio como de outros níveis de ensino.

4) Trabalhos do tipo estado da arte: consideramos dois trabalhos do tipo estado da arte que apresentaram levantamentos bibliográficos sobre trabalhos da ANPED a respeito da formação de professores. Prada, Vieira e Longarezi (2009) realizaram um levantamento no período de 2003 a 2007 no Grupo de Trabalho Formação de Professores (GT8) com o objetivo de conhecer as tendências das pesquisas no campo da formação de professores deste evento. Santos (2009) também propôs levantamento bibliográfico no período de 2000 a 2008 nos Grupos de Trabalho Formação de Professores (GT8) e Educação e Comunicação (GT16) com o intuito de compreender como a formação de professores 
tem tratado o uso das tecnologias. Como resultados Prada, Vieira e Longarezi (2009) apontam que as reflexões oportunizadas pelas pesquisas ainda mostram-se pontuais, fazendo uso de referenciais, em sua maioria, estrangeiros (europeus e americanos) utilizados mais confirmar as ideias dos autores do que para questioná-las ou ampliá-las, tal forma de pesquisa, pautada na repetição de pensamento de autores revela a ausência de novas concepções e práticas docentes. Já Santos (2009) afirma que a análise das pesquisas aponta aumento do interesse da temática no decorrer dos anos, afirmando que estas pesquisas acontecem em nível de formação inicial, continuada, propostas de cursos e políticas públicas. Entretanto as pesquisas evidenciam que muito se tem por fazer nesse campo tendo em vista as dificuldades encontradas em relação à formação de professores e o uso de tecnologias. Em ambos os trabalhos não houve explicitação de trabalhos voltados para o Ensino Médio, estes foram analisados com os demais níveis de ensino.

5) Professor do Ensino Médio: nesta categoria elencamos os trabalhos que explicitaram com clareza processos de formação e o perfil do professor do ensino médio. Nogueira e Ferreira (2002) tiveram como objetivo captar elementos do perfil do professor do ensino médio compreendendo algumas representações destes professores em relação a sua profissão, a pesquisa foi realizada com 80 professores do ensino médio do município de Fortaleza (CE). A autora afirma que o professor do Ensino Médio possui um perfil bem delineado, com características próprias, e em seu estudo apontam essas diversas características e defende que as pesquisas de um modo geral tratam a formação de professores de modo homogêneo, entretanto a diversidade de tais perfis deve ser considerada. Gomes (2004) realizou uma pesquisa com professores e ensino médio/técnico com vistas a conhecer como os professores entendem as mudanças ocorridas neste nível para, a partir daí, trabalhar com a formação contínua destes professores. Os seus resultados apontam para educação da formação do professor médio-técnico, a autora declara que o discurso dos professores para enfrentar as modificações, com participação e atuação tem que possuir um conjunto de conhecimentos amplos e diversas naturezas que são construídos ao longo de sua carreira e que, portanto demanda maturidade a apoio tanto das instituições como da sociedade como um todo. Nuñez (2004) teve como intuito investigar as necessidades formativas dos professores de nível médio da rede do Rio Grande do Norte, a fim de levantar temáticas para cursos de aperfeiçoamento que visassem o desenvolvimento profissional, em uma análise exaustiva o autor apresenta diversas competências a serem desenvolvidas pelo professor de nível médio e que foram apresentadas pelos sujeitos da pesquisa como necessidades formativas, que declaram e apontam que a proposta pedagógica é um dos grandes desafios a ser vencido.

6) Epistemologia da prática profissional: esta categoria inclui o trabalho de Mendes (2008) que tem como objeto de investigação professores que obtém sucesso com seus alunos e êxito em sua vida profissional. A pesquisa foi realizada com 3 professoras que foi indicada pela maioria de 191 alunos (por meio de questionário) como professoras exitosas. A pesquisa se ateve em compreender os aspectos da prática significativa a partir desses casos. Como resultados a autora aponta que a prática significativa está atrelada ao desenvolvimento de uma prática em que as dimensões da competência se articulem. A partir desta afirmação a autora elenca os diversos pontos deste tipo de prática docente. Sudan, Vilani e Freitas (2006) apresentam um estudo de caso de uma professora de biologia atuante no ensino médio, em que ela teve o objetivo de investigar a própria prática, relacionando aspectos objetivos e subjetivos da prática docente, a partir dos pressupostos de Schön. Os autores apontam como resultado um avanço significativo ao oportunizar para a professora a reflexão sobre sua própria prática e a possibilidade de reflexão e investigação na ação.

De um modo geral, nossos dados trazem à tona a escassez de pesquisas que tratem da formação do professor do ensino médio e do seu trabalho docente. Ainda que se deva considerar as especificidades das áreas e suas publicações em eventos específicos, fazem necessárias as discussões no âmbito da formação do professor, e aí se incluem todos os níveis de ensino, da Educação Infantil ao Ensino Superior. Isso porque, conforme os diversos autores da área, a formação é um contínuo, devendo ser discutida e refletida tanto nos espaços de formação inicial, como continuada e como reflexão da própria prática docente, com vias de oportunidade de desenvolvimento e autonomia profissional (ANDRÉ, 2010; DINIZ-PEREIRA, 2013; CUNHA, 2017). Colocamos em evidência também que as pesquisas desse nível devem aparecer pelo fato de fazer parte da educação básica, que tem como objetivo a formação integral do educando. Tal escassez indica desarticulação dos níveis de ensino, o que deve ser posto em discussão.

As discussões sobre o trabalho docente, o fazer do professor do ensino médio e as relações que no espaço da escola e da sala de aula se estabelecem parecem inexistentes nas publicações da ANPED. Em nossos resultados podemos citar apenas as pesquisas de Mendes (2008) e Sudan, Villani e Freitas (2006) em que demonstraram o interesse sobre o trabalho dos professores envolvidos na pesquisa. Isto deixa evidente 
que ainda carecem estudos que tratem desta perspectiva, já que o universo do ensino médio pode ser apontado por inúmeros problemas, os quais são objeto de estudo de muitos autores (JESUS, 2002; REBOLO; BUENO, 2014), problemas tais como os de violência, condições precárias advindas do trabalho em diversas escolas, com número elevado de alunos por salas e com muitas turmas; a falta de estabilidade pelo número reduzido de concursos públicos, baixos salários, além das relações interpessoais que no desenvolvimento do trabalho se fazem essenciais e podem gerar frustrações e angústias, aspectos os quais muitos autores.

\section{CONSIDERAÇÕES FINAIS}

Sem a pretensão de fazer uma análise exaustiva dos trabalhos referentes à temática formação de professores do nível/ensino médio dos grupos de trabalho da ANPED no período de 2000 a 2016, encontramos alguns apontamentos que indicam os principais focos dos pesquisadores e os temas que não tiveram atenção, o que possibilita algumas reflexões sobre a temática.

As pesquisas sobre o ensino médio tem sua atenção voltada para trabalhos que envolvam as políticas públicas, o mundo do trabalho, o ensino técnico, questões sociais entre os jovens e atividades de ensino e aprendizagem com os alunos. Tal foco pode ser justificado pelas políticas públicas envolvendo o ensino médio e o ensino técnico, que dentro da perspectiva neoliberal, tem o objetivo de formação do jovem para o mundo do trabalho. As propostas de programas de formação ficam em nível de cursos de capacitação e aperfeiçoamento e ainda as diretrizes curriculares que embasam os cursos de formação inicial das licenciaturas.

De modo que consideramos pequeno o número de trabalhos que tratam as discussões sobre o trabalho docente e a formação do professor do nível médio nas publicações da ANPED, apenas 20 artigos trataram acerca da temática. E, quando focamos a nossa atenção especificamente para os saberes, autonomia, trabalho docente e desenvolvimento profissional desse grupo de professores, apenas três trabalhos versaram sobre a temática, os outros abordam a construção da identidade docente, a formação inicial, cursos de capacitação e desenvolvimento profissional, trabalhos de levantamento do tipo estado da arte e a epistemologia da prática docente da educação básica como um todo e, que por sua vez, englobam a formação do professor do Ensino Médio.

As pesquisas também se mostram pontuais, como resultados de teses e dissertações, e pesquisas individuais sem grande representatividade de grupos de pesquisas que consideram a temática e a investigam nos diferentes aspectos. Isso também pontua para pouca modificação da realidade dos professores do ensino médio. Em relação aos referenciais teóricos, parece um consenso sobre os teóricos da formação de professores sendo um consenso nos artigos. Os referenciais brasileiros começam a serem referenciados na medida em que se consolida o campo de formação de professores no Brasil.

De um modo geral, apontamos que, para que se tenham pesquisas que contribuam para a transformação da realidade no cenário da formação dos professores do ensino médio, faz-se necessário pesquisas mais aprofundadas em que esse estabeleçam parcerias entre a universidade, grupos de pesquisas e escolas e entre as diferentes áreas de conhecimento em uma perspectiva de interdisciplinaridade, integração e de trabalho coletivo, que partam das reflexões sobre autonomia e saberes docentes, desenvolvimento profissional e preparação profissional em relação ao real contexto em que este professor está inserido, na tentativa de elaboração de estratégias reais para reflexão e mudança na e da ação. Além disso, pontuamos ser de suma importância que as políticas públicas atuem nesse sentido e contribuam com a valorização da formação desta categoria de professor e que não se restrinja aos cursos aligeirados, que visam apenas obtenção de diploma, principalmente nesse cenário atual das políticas educacionais do Ministério da Educação (MEC) em alterar toda a constituição do Ensino Médio para um Ensino Médio Técnico.

\section{REFERÊNCIAS}

[1] ALARCÃO, I. Ser professor reflexivo. In: ALARCÃO, Isabel. (ORG.). Formação reflexiva de professores estratégias de supervisão. Editora Porto: Porto, Portugal, 1996.

[2] ANDRÉ, M. Formação de professores: a constituição de um campo de estudos. Educação, Porto Alegre, v. 33, n. $3, \quad$ p. $174-181, \quad$ set./dez. $2010 . \quad$ Disponível http://revistaseletronicas.pucrs.br/ojs/index.php/faced/artilce/view/8075/5719. Acesso em 21 jan. 2017.

[3] AZAMBUJA, G ; OLIVEIRA, V. F. de. Processos de formação de um professor. 23a Reunião da ANPED, Caxambu, MG, 2000. 
[4] BELINTANE, C. Por uma ambiência de formação contínua de professores. Cadernos de Pesquisa, n. 117, p. 177-193, nov. 2002.

[5] BRANCO, A. M. B; BRANCO, C. B; PETRILLI, S. R. P. HTPC como espaço coletivo de formação docente: um estudo sobre o espaço de formação continuada em serviço de professores da rede pública municipal de ensino de Araçatuba - SP. Avesso do Avesso, v. 8, n.8 Edição Especial 2010.

[6] CORREIRA, C. C.; BONIFÁCIO, R. S.; NUNES, L. C. O curso de capacitação de professores em informática educativa como possibilidade de mudança na prática docente. 30 a Reunião da ANPED, Caxambu, MG, 2007.

[7] CUNHA, M. I. O tema da formação de professores: trajetórias e tendências do campo na pesquisa e na ação. Educ. Pesqui., São Paulo, n. 3, p. 609-625, jul./set. 2013. Disponível em: http://www.scielo.br/pdf/ep/v39n3/aop1096.pdf. Acesso em: 21 jan. 2017.

[8] DINIZ-PEREIRA, J. E. A construção do campo da pesquisa sobre formação de professores. Revista da FAEEBA - Educação e Contemporaneidade, Salvador, v. 22, n. 40, p. 145-154, jul./dez. 2013.

[9] DE PAULA, S. G. Formação continuada de professores: perspectivas atuais. Paidéia: Belo Horizonte. n. 6 , jan./jun.2009.

[10] FREITAS, D.; VILLANI, A.; PIERSON, H. C.; FRANZONI, M. Conhecimento e saber em experiência de formação de professores. 23ㄹ Reunião da ANPED, Caxambu, MG, 2000.

[11] FUSARI, J. C.; FRANCO, A. P. A formação contínua como um dos elementos organizadores do projeto políticopedagógico da escola. In: Formação contínua de professores. MEC, Boletim 13, Ago. 2005, p. 18-23.

[12] GARCIA, J. Repensando a formação do professor interdisciplinar. 25 $5^{\mathrm{a}}$ Reunião da ANPED, Caxambu, MG, 2002.

[13] GENTIL, H. S. Identidades de professores e reder de significações - configurações que constituem o "nós, professores". 29a Reunião da ANPED, Caxambu, MG, 2006.

[14] GOMES, H. M. Formando professores para a educação profissional. 27ª Reunião da ANPED, Caxambu, MG, 2004.

[15] HYPOLITTO, D. O professor como profissional reflexivo. Integração. São Paulo, n. 18, ago. 1999. p. 204-205.

[16] IMBERNÓN, F. Formação continuada de professores. Trad. Juliana dos Santos Padilha. Porto Alegre: Artmed, 2010.

[17] JESUS, S.N. de. Perspectivas para o bem-estar docente. Uma lição de síntese. Porto: ASA, 2002, 63p.

[18] JORDÃo, R. dos S. A pesquisa-ação na formação inicial de professores: elementos para a reflexão. 26ํㅜ Reunião da ANPED, Poços de Caldas, 2003.

[19] LAPO, F.R.; BUENO, B. O. Professores, desencanto com a profissão e abandono do magistério. Cadernos de pesquisa, n. 118, p. 65-88, março/2003.

[20] LOPES, A. Mal-estar na docência? Visões, razões e soluções. Porto: ASA, 2001. 61p.

[21] MELO, G. F. Questões exatas, respostas incertas: dilemas e perspectivas na formação de professores de física, matemática e química. 30ª Reunião da ANPED, Caxambu, MG, 2007.

[22] MENDES, M. C. de J. Professoras bem-sucedidas: saberes e práticas. 31aㅡ Reunião da ANPED, Caxambu, MG, 2008.

[23] NEZ, Egeslaine de; ZANOTTO, Marijane. A formação continuada em questão. Educere et Educare: Revista de Educação. V. 1. № 1. Jan./Jun. 2006, p. 257-262.

[24] NOGUEIRA, J. F. F.; FERREIRA, E. A. Profissão professor do ensino médio. 25a Reunião da ANPED, Caxambu, MG, 2002.

[25] NÓVOA, A. Para uma formação de professores construída dentro da profissão. IN: do futuro presente. Educa: Lisboa, 2009. p. 10-18.

[26] NÚÑEZ, I. B. Estudo das necessidades formativas de professores (as) do ensino médio no contexto das reformas curriculares. 27aㅡ Reunião da ANPED, Caxambu, MG, 2004.

[27] PACCA, J. L. A.; VILANNI, A. Conhecimento e saber do professor de física: uma interpretação psicanalítica. 23ạ Reunião da ANPED, Caxambu, MG, 2000.

[28] PERREnoud, P. 10 Novas Competências para Ensinar. Trad. Patrícia Chittoni Ramos. Porto Alegre: Ed. Artmed, 2000.

[29] PRADA, L. E. A.; VIERA, V. M. de O.; LONGAREZI, A. M. Concepções de formação de professores nos trabalhos da ANPED 2003-2007. 32 a Reunião da ANPED, Caxambu, MG, 2009. 
[30] REBOLO, F; BUENO, B.O. O bem-estar docente: limites e possibilidades para a felicidade do professor no trabalho. Acta Scientarium. Education. Maringá, v. 36, n.2, p. 323-331, July-Dec 2014.

[31] SANTOS, E. T. A formação dos professores para o uso das tecnologias digitas nos GTS formação de professores e educação e comunicação da ANPED - 2000 A 2008. 32 a Reunião da ANPED, Caxambu, MG, 2009.

[32] SANTOS, S. R. M. dos; A universidade e a formação continuada de professores: dialogando sobre a autonomia profissional. 26aㅡ Reunião da ANPED, Poços de Caldas, 2003.

[33] SCHÖN, D. A. Formar professores como profissionais reflexivos. In: NÓVOA, Antônio. Os professores e sua formação. Dom Quixote, Lisboa, 1992.

[34] SOUZA, G. R. As horas de trabalho pedagógico coletivo (HTPC) considerando a escola pública como local de formação contínua de professores. Colloquium Humanarum, vol. 9, n. Especial, jul.-dez, 2012.

[35] SUDAN, D. C.; VILLANI, A.; FREITAS, D. Professor-pesquisador: o caso da professora Flora. 29a Reunião da ANPED, Caxambu, MG, 2006.

[36] TRISTÃO, M. Os sentidos da educação ambiental nos contextos de formação de professores/as. 24⿳亠口冋 Reunião da ANPED, Caxambu, MG, 2001.

[37] VAILLANT, Denise; MARCELO, Carlos. Ensinando a ensinar: as quatro etapas de uma aprendizagem. Trad. LOPES, M. S. 1. Ed. Curitiba: Ed. UTFPR, 2012.

[38] VAZ, A.; MENDES, R.; MAUÉS, E. Episódios e narrativas de professores - experiências e perspectivas docentes discutidas a partir de pesquisa sobre conhecimento pedagógico de conteúdo. 24를 Reunião da ANPED, Anais da 30ª Reunião da ANPED, Caxambu, MG, 2001.

[39] VOGT, G. Z. Formação continuada de professores e reunião pedagógica: construindo um estado de conhecimento. IX ANPED SUL (Seminário de pesquisa da região sul), 2012. Anais do IX ANPED SUL, Caxias do Sul, 2012.

[40] XAVIER, G. P. de M. A formação continuada dos profissionais da educação e o desafio de pensar multiculturalmente uma escola pública de qualidade. 30 ำ Reunião da ANPED, Anais da 30 a Reunião da ANPED, Caxambu, MG, 2007.

[41] ZEICHNER, K. M. A formação reflexiva de professores: ideias e práticas. Lisboa: Educa, 1993. 


\section{Capítulo 17}

Formação de professores para atuação na educação profissional e tecnológica - Horizontes possíveis

\section{Rosangela Santos da Silva \\ Adriana Neves de Almeida \\ Luciani Andrade de Andrade \\ Ana Cláudia Ribeiro de Souza}

Resumo: 0 presente artigo apresenta reflexões sobre a relevância da formação de professores para atuar na Educação Profissional e Tecnológica, em especial na Educação Profissional Técnica de Nível Médio no contexto do Ensino Médio Integrado, perspectivando horizontes possíveis para um processo formativo propositivo, duradouro e efetivo que contribua significativamente para a potencialização da prática pedagógica dos professores que atuam na EPTNM e para a concretização, no interior das instituições, da perspectiva da Formação Humana Integral de jovens e adultos trabalhadores. Para tanto, o percurso metodológico delineado para a realização desse estudo consubstanciou-se na pesquisa bibliográfica, com foco no levantamento das contribuições teóricas de diversos autores sobre a temática da Formação de Professores para atuação na Educação Profissional e Tecnológica. Como resultados, apontamos a necessidade urgente e inadiável do fomento à construção de processos de formação de professores duradouros e propositivos, que assumam novos contornos, deixando de se configurar como ações emergenciais, pontuais e dispersas, e se constituam como política pública duradoura e efetiva que propicie a formação inicial e continuada, que os credencie à atuação socialmente referenciada na Educação Profissional e Tecnológica, mas especificamente no contexto do Ensino Médio Integrado.

Palavras-Chaves: Educação Profissional e Tecnológica, Formação de Professores, Ensino Médio Integrado. 


\section{INTRODUÇÃO}

Os diálogos envolvendo a política de formação de professores para a Educação Profissional e Tecnológica EPT vêm cada vez mais ganhando espaço no contexto nacional, considerando as mudanças estruturais ocorridas no mundo do trabalho e nas proposições legais e políticas da Educação Profissional e Tecnológica. Retomando algumas discussões travadas por teóricos que se debruçam nos estudos e pesquisas sobre a política de formação de professores para a EPT, evidencia-se a necessidade latente de construção de uma política de formação de professores duradoura, propositiva e efetiva que atenda às especificidades dessa modalidade de ensino, uma vez que um número significativo de professores que atuam na Educação Profissional e Tecnológica e na Educação Profissional Técnica de Nível Médio EPTNM, especialmente, aqueles vinculados aos Cursos Técnicos de Nível Médio na Forma Integrada, apresentam-se ainda como "leigos" no que se refere à concretização teórica e prática dos pressupostos pedagógicos e metodológicos do Ensino Médio Integrado em suas instituições.

Nesse caminho, esse estudo se propõe realizar reflexões sobre a relevância da formação de professores para atuar na Educação Profissional e Tecnológica, em especial na Educação Profissional Técnica de Nível Médio no contexto do Ensino Médio Integrado, perspectivando horizontes possíveis para um processo formativo propositivo, duradouro e efetivo que contribua significativamente para a potencialização da prática pedagógica dos professores que atuam na EPTNM.

\section{METODOLOGIA}

O percurso metodológico delineado para a realização desse estudo consubstanciou-se na pesquisa bibliográfica, com foco no levantamento das contribuições teóricas de diversos autores sobre a temática da Formação de Professores para atuação na Educação Profissional e Tecnológica e mais especificamente na Educação Profissional Técnica de Nível Médio no contexto do Ensino Médio Integrado.

A pesquisa bibliográfica segundo Prodanov e Freitas (2013, p.54), caracteriza-se como um estudo bibliográfico,

Quando elaborada a partir de material já publicado, constituído principalmente de: livros, revistas, publicações em periódicos e artigos científicos, jornais, boletins, monografias, dissertações, teses, material cartográfico, internet, com o objetivo de colocar o pesquisador em contato direto com todo material já escrito sobre o assunto da pesquisa.

Cabe destacar que para a concretização desse estudo aportamo-nos nas contribuições de Machado (2011), Moura (2008), Araújo (2008), Bazzo (2015), Pena (2011), Santos, Ferreira e Araújo (2012), dentre outros.

\section{RESULTADOS E DISCUSSÕES}

Com a expressiva expansão da Rede Federal de Educação Profissional, Científica e Tecnológica, evidenciase o ingresso de um número significativo de professores nos Institutos Federais de Educação, Ciência e Tecnologia que não possuem experiência prática na atuação pedagógica na Educação Profissional Técnica de Nível Médio, especialmente no contexto do Ensino Médio Integrado, uma vez que essa forma de oferta da EPT que articula a Educação Básica à Educação Profissional Técnica de Nível Médio, apresenta especificidades e nuances em sua concepção pedagógica que busca romper com a dualidade histórica que marca essa relação, oriunda da divisão social do trabalho, a qual reforça a separação entre formação geral e formação profissional na formação de jovens e adultos trabalhadores, distinguindo os que pensam, daqueles que apenas executam.

Cabe destacar que ao longo desse processo de expansão da Rede Federal, vários estudos tem apontado o ingresso de professores que apresentam diferentes níveis de formação e que ainda possuem limitações quanto aos atributos pedagógicos necessários para atuação na EPTNM e no Ensino Médio Integrado, considerando as especificidades dessa modalidade e forma de oferta. Ressalta-se que até mesmo os professores licenciados, vinculados às disciplinas da formação geral, e que se pressupõe já possuir formação pedagógica, construída ao longo de seu processo de formação inicial, ainda demonstram dificuldades para desenvolver na prática a proposta pedagógica do Ensino Médio Integrado e do Currículo Integrado, ancorados nos pressupostos da Formação Humana Integral. Estes também precisam, a exemplo dos tecnólogos e bacharéis, de processos de formação continuada que discutam os princípios educativos da pesquisa e do trabalho, sobre a ciência, a tecnologia e a cultura numa perspectiva sócio-crítica. Estudos 
que contribuam para credenciá-los e potencializem suas atuações com foco na efetivação e materialização do Ensino Médio Integrado em suas instituições.

Sobre isso, Machado (2011, p.694) adverte-nos que muitos professores compreendem erroneamente a proposta do Ensino Médio Integrado, a partir dos pressupostos delineados pela Lei no 5.692/71, considerando que esta é apenas uma justaposição das disciplinas que compõem a parte propedêutica com a formação profissional. Aqui cabe destacar que uma parcela expressiva desses profissionais, considerando as lacunas existentes em sua formação inicial, somadas ao incipiente processo de formação continuada, não demonstram compreender os pressupostos teóricos do Ensino Médio Integrado, a concepção pedagógica que norteia suas ações, os princípios orientadores e suas diretrizes de ação.

No intuito de qualificar a ação desses professores na materialização e operacionalização do Ensino Médio Integrado, torna-se necessário fomentar um processo de reflexão sobre a prática pedagógica desses professores que atuam na Educação Profissional Técnica de Nível Médio, consubstanciados pelas proposições teóricas da real concepção de "integração" que o Ensino Médio Integrado nos apresenta, ancorados na perspectiva da politecnia e da Formação Humana Integral. Para consolidar o Ensino Médio Integrado no cotidiano de suas instituições, esses professores precisam estar minimamente fundamentados. Sabe-se que essa não é tarefa fácil, como reafirma Machado (2011, p.694),

Pôr em prática currículos integrados demanda formação docente continuada, de modo a assegurar o necessário trabalho coletivo e colaborativo dos professores de conteúdos da educação geral e profissional; a compreensão de como desenvolver os princípios educativos do trabalho, da ciência, da tecnologia e da cultura; o diálogo entre a teoria e a prática; o pensar e o agir na lógica da interdisciplinaridade; a sintonia com o desenvolvimento tecnológico e o contexto socioeconômico e ambiental.

Importante destacar que a obtenção de avanços didáticos e pedagógicos no processo de efetivação do Ensino Médio Integrado e do Currículo Integrado no cotidiano das instituições, pressupõe investimentos em formação continuada. Contudo, essa não é uma prática que se materializa cotidianamente nas instituições de forma geral. Portanto, mudar essa realidade vai requerer incluir essa ação na pauta e no planejamento estratégico dessas instituições, materializando-se como uma ação sistemática e propositiva, possibilitando aos professores a oportunidade de aprender, por meio de processos de formação continuada desenvolvida em cursos formais, em discussões durante as reuniões pedagógicas, na troca de experiências entre os pares, na experiência de práticas integradoras planejadas e que possam ocorrer de maneira mais sistematizada, enquanto se constituem como docentes. Contudo, para tanto, faz-se necessário que haja vontade política e destinação de tempo e espaço para os professores.

Ainda nesse caminho de avanços pedagógicos e didáticos, apresenta-se como necessária outra ação, além da formação continuada, que diz respeito ao fomento do processo de articulação e interlocução entre os professores da formação geral e da formação profissional, que precisa ser promovida e planejada pela gestão macro e micro das instituições, de forma a possibilitar a realização de reuniões coletivas focadas no estudo da proposta pedagógica do Ensino Médio Integrado e no planejamento, análise e construção do Currículo Integrado. Faz-se necessário ainda fomentar no interior dessas instituições os estudos e análises de estratégias e metodologias ativas que se convertam em práticas pedagógicas interdisciplinares e integradoras, metodologias estas potencialmente relevantes para a materialização do Ensino Médio Integrado, uma vez que contribuem significativamente na organização dos conhecimentos, promovendo o incentivo à realização de pesquisas, além de contribuir para o estabelecimento de uma relação entre os saberes das diversas áreas, oportunidade em que se articula concretamente a formação geral com a formação profissional.

Legitimando a relevância dessa articulação, Pena (2011, p.102) recomenda oportunizar aos professores espaços coletivos de discussões e de formações com vistas ao fortalecimento da prática pedagógica, por meio da troca de experiências entre os profissionais da EPTNM, oportunizando a socialização de experiências cognitivas, metodológicas e até afetivas. A autora defende que a construção dessa cultura de formação continuada se converte em significativa contribuição para potencializar a prática pedagógica desses professores e tendem a transformar essas instituições promotoras dessa prática em "lócus de formação".

Reafirmando essa perspectiva, o Documento Base que apresenta a proposta de Educação Profissional Técnica de Nível Médio, integrada ao Ensino Médio, aponta a necessidade de formação continuada, assim como de mudança na cultura pedagógica das instituições, em que se busque romper com a fragmentação dos conhecimentos, sinalizando que "[...] a formação continuada para professores, gestores e técnicos tem um papel estratégico na consolidação dessa política" (BRASIL, 2007, p.33). 
Nesse contexto, faz-se necessário lançar um olhar mais apurado para a problemática da formação de professores para a EPTNM, especialmente para aqueles que atuam no Ensino Médio Integrado. E tal ação requer buscar garantias de mudanças desse cenário, consubstanciados na materialização do que preconiza os aportes legais sobre a formação de professores, fomentando e implementando ações formativas e propositivas no âmbito das instituições de Educação Profissional e Tecnológica. Assim, a LDB n 9394/96, em seu título VI e artigos 61 a 67, estabelece as diretrizes macro para a formação dos profissionais da educação, preconizando, em seu inciso II, artigo 67, que a valorização dos professores se dará, dentre outros fatores, mediante "[...] aperfeiçoamento profissional continuado, inclusive com licenciamento periódico remunerado para esse fim".

Santos, Ferreira e Araújo (2012, p.8), ao analisar essa proposição da lei, argumentam que,

[...] reforça-se a exigência para cursos de formação que supram não só as deficiências resultantes do distanciamento entre o processo de formação docente e sua atuação profissional, mas também a necessidade de preparar um professor afinado com práticas pedagógicas voltadas para a construção do conhecimento de acordo com as exigências que se colocam no atual estágio do desenvolvimento da humanidade.

Nesse mesmo caminho, a Resolução CEB/CNE n 6/2012 (p.12), que define as Diretrizes Curriculares Nacionais para a Educação Profissional Técnica de Nível Médio - DCNEPTNM, em seu título IV, artigo 40, também destaca o compromisso efetivo que se deve ter com a formação de professores para atuar especificamente na EPTNM, preconizando que,

A formação inicial para a docência na Educação Profissional Técnica de Nível Médio realiza-se em cursos de graduação e programas de licenciatura ou outras formas, em consonância com a legislação e com normas específicas definidas pelo Conselho Nacional de Educação.

Vale destacar que as DCN para a EPTNM evidenciam a relevância do princípio orientador - pesquisa como princípio pedagógico, capaz de fomentar a articulação entre pesquisa e ensino na formação de professores e na formação de jovens e adultos trabalhadores. Sobre isso, Bazzo (2015, p.36) defende que os professores que atuam na EPT, devem buscar integrar pesquisa e ensino, propiciando aos jovens e adultos trabalhadores uma educação em essência formadora, de forma a desenvolver o espírito de investigação, minimizando dessa forma, o fosso que separa as questões de ordem pedagógica das questões de ordem investigativa.

A nova Resolução CNE n² 2/2015 (BRASIL, 2015, p.3), que define as Diretrizes Curriculares Nacionais para a formação inicial em nível superior, ainda na perspectiva de materializar o que preconiza o aporte legal, define, em seu art. $3^{\circ}$ a quem se destina a formação inicial e continuada, sinalizando que,

A formação inicial e continuada destinam-se, respectivamente, à preparação e ao desenvolvimento de profissionais para funções de magistério na educação básica em suas etapas - educação infantil, ensino fundamental, ensino médio - e modalidades - educação de jovens e adultos, educação especial, Educação profissional e técnica de nível médio, educação escolar indígena, educação do campo, educação escolar quilombola e educação a distância - a partir de compreensão ampla e contextualizada de educação e educação escolar, visando assegurar a produção e difusão de conhecimentos de determinada área e a participação na elaboração e implementação do projeto político-pedagógico da instituição, na perspectiva de garantir, com qualidade, os direitos e objetivos de aprendizagem e o seu desenvolvimento, a gestão democrática e a avaliação institucional.

Vale evidenciar que a DCN para a formação de professores (BRASIL, 2015, p.5), também faz o reforço à relevância da formação inicial e continuada de professores para atuar na Educação Profissional Técnica de Nível Médio, sinalizando a necessidade de se investir na formação desses profissionais para garantir uma atuação socialmente referenciada na EPT. Para tanto, preconiza um conjunto de princípios que devem balizar o processo de formação e ainda balizar a prática pedagógica dos professores. Destaques para,

II- a formação dos profissionais do magistério (formadores e estudantes) como compromisso com o projeto social, político e ético que contribua para a consolidação de uma nação soberana, democrática, justa, inclusiva e que promova a emancipação dos indivíduos e grupos sociais, atenta ao reconhecimento e à valorização da diversidade e, portanto, contrária a toda forma de descriminação; 
V - a articulação entre teoria e prática no processo de formação docente, fundada no domínio dos conhecimentos científicos e didáticos, contemplando a indissociabilidade entre ensino, pesquisa e extensão;

$\mathrm{X}$ - a compreensão da formação continuada como componente essencial da profissionalização, inspirado nos diferentes saberes e na experiência docente, integrando-a ao cotidiano da instituição educativa, bem como ao projeto pedagógico da instituição de educação básica.

Cabe considerar que mesmo com todo esse aporte legal apontando horizontes viáveis para a formação de professores, em especial os que atuam na EPT, as ações formativas ainda apresentam-se incipientes, apontando um cenário que demonstra a necessidade imperiosa e inadiável da formação de professores para atuação socialmente referenciada na Educação Profissional e Tecnológica, e da construção de uma política de formação de professores duradoura, propositiva e efetiva que não se limite apenas em ações pontuais e dispersas como tem acontecido historicamente. Nesse sentido, Moura (2008, p.39) argumenta que,

O professor precisa ser formado na perspectiva de que a pesquisa e o desenvolvimento tecnológico devem estar voltados para a produção de bens e serviços que tenham a capacidade de melhorar as condições de vida dos coletivos sociais e não apenas para produzir bens de consumo para fortalecer o mercado e, em consequência, concentrar riqueza e aumentar o fosso entre os indivíduos e os excluídos.

Partindo dessa premissa, uma Educação Profissional e Tecnológica com qualidade socialmente referenciada, pressupõe um quadro de professores com formação sólida e reflexiva; com atuação qualitativa em sala de aula, com postura de pesquisadores de sua prática e mobilizadores de conhecimentos, sempre atentos às novas exigências do mundo do trabalho. Forjados nesse perfil, serão capazes de contribuir para desenvolver nos jovens e adultos trabalhadores, as habilidades necessárias para atuação socialmente referenciada no mundo do trabalho, fortalecendo o domínio dos conhecimentos científicos, tecnológicos, históricos, sociais e principalmente, desenvolvendo e potencializando a dimensão da formação humana.

Nesse mesmo caminho, problematizando o perfil do professor da EPT, Araújo (2008, p.9), defende que o novo perfil recomendado para um professor que atua na Educação Profissional e Tecnológica, traduz-se em,

Intelectual; problematizador, mediador do processo ensino-aprendizagem, promotor do exercício da liderança intelectual, orientador sobre o compromisso social que a ideia de cidadania contém e orientador sobre o compromisso técnico dentro de sua área de conhecimento.

Fazendo um reforço a esse perfil requerido, Machado (2008, p.17), argumenta que o perfil do professor para atuar no Ensino Médio Integrado à EPT traduz-se em,

[...] saber integrar os conhecimentos científicos, tecnológicos, sociais e humanísticos, que compõem o núcleo comum de conhecimentos gerais e universais, e os conhecimentos e habilidades relativas às atividades técnicas de trabalho e de produção relativas ao curso técnico em questão.

Sobre isso, Machado (2011, p.694) faz um destaque para o desafio que se apresenta quanto à formação de professores para atuação socialmente referenciada na Educação Profissional e Tecnológica. Segundo ela, esse desafio,

[...] Manifesta-se de vários modos, principalmente quando se pensa nas novas demandas nas novas necessidades e demandas políticopedagógicas dirigidas a eles: mais diálogos com o mundo do trabalho e educação geral; práticas pedagógicas interdisciplinares e interculturais, enlaces fortes e fecundos entre tecnologia, ciência e cultura; processos de contextualização abrangentes; compreensão radical do que representa tomar o trabalho como princípio educativo; perspectiva de emancipação do educando; porquanto sujeitos de direitos e da palavra.

Mesmo diante dos desafios apresentados, algumas instituições ainda insistem em atuar na contramão dessas propostas, desconsiderando os horizontes legais e teóricos que apontam para a relevância do processo de formação de professores e para a construção de um perfil de professor forjado para atuação do Ensino Médio Integrado, pois como afirma Machado (2011, p.691), “[...] ainda se recrutam professores 
para a EPT fiando-se apenas em formação especifica e experiência pratica, crendo que a constituição da docência se dará pelo autodidatismo".

Neste mesmo caminho, Bazzo (2015, p.21), também chama a atenção para o fato de que as instituições continuam absorvendo os docentes que pouco ou nada dominam das questões didáticas, pedagógicas ou práticas inovadoras, desde que estes sejam profissionais reconhecidos pela sua competência técnica na área de atuação, relegando, dessa forma, a segundo plano, a formação didático-pedagógica desses profissionais.

Então, como mudar essa realidade, considerando as transformações que tem se processado do mundo trabalho e ainda "[...] a dinâmica tecnológica e de produção de conhecimentos, a diversidade cultural, a sustentabilidade ambiental, a vida em sociedade" (MACHADO, 2011, p.693), sem perder de vista que novas exigências são requeridas para a atuação socialmente referenciada dos professores, transformando o exercício da docência em uma ação mais complexa, uma vez que exige práticas pedagógicas mais coerentes, mais consistentes, que promovam o diálogo e a participação dos jovens e adultos trabalhadores em todas as fases do processo educativo.

Diante desse quadro evidenciado, investir na atualização de conhecimentos dos professores e no consequente fomento de novas e efetivas práticas pedagógicas interdisciplinares e integradoras, pressupõe ponto chave e definidor para a materialização do Ensino Médio Integrado no interior das instituições que atuam com a EPT. Para tanto, todos os sujeitos envolvidos com a Educação Profissional e Tecnológica, principalmente, os professores, tem o desafio de "[...] superar as barreiras entre o ensino técnico e o científico de modo que seja possível articular trabalho, ciência e cultura em uma perspectiva de emancipação humana" (FIGHERA; JUCHEM; SANTOS, 2012, p.2).

Nesse contexto, a formação pedagógica e continuada dos professores da EPT deve ganhar dimensões importantes no âmbito das instituições envolvidas com essa modalidade de ensino, em que se busque desenvolver programas de formação pedagógica com vistas a potencializar a atuação de seus professores, oportunizando a eles a continuidade de sua formação, após seus estudos em nível superior, considerando a rápida evolução dos conhecimentos em todos os campos. Sem contar que, segundo Bazzo (2015, p.19),

A necessidade de formação contínua, hoje em dia, é questão de sobrevivência. 0 mundo do trabalho e das relações sociais tornou-se mais difícil, mais complexo e quem se comportar segundo os padrões antigos se arrisca a ingressar na fila dos "equipamentos" obsoletos.

Considerando o exposto, é mister que os Institutos Federais e as demais instituições que atuam com a EPT no país transponham esse grande desafio, traduzido na busca por mecanismos que possam garantir a construção desse perfil de professor requerido. Desafio este, que se amplia quando historicamente, não se tem investido na formação inicial e continuada dos professores que atuam diretamente nessa modalidade de ensino.

\section{CONSIDERAÇÕES FINAIS}

Embora ao longo dos últimos anos, considerando a expressiva expansão da Rede Federal, Científica e Tecnológica tenha se ampliado os investimentos em infraestrutura, recursos humanos e tecnológicos na Educação Profissional e Tecnológica, ampliando as diferentes vozes na luta por uma política de formação de professores que busque concretizar no interior das instituições a perspectiva da Formação Humana Integral de jovens e adultos trabalhadores, não se pode incorrer no equívoco de negar e muito menos negligenciar a necessidade urgente e inadiável do fomento à construção de processos de formação de professores duradouros e propositivos que os credencie à atuação socialmente referenciada na Educação Profissional e Tecnológica, mas especificamente no contexto do Ensino Médio Integrado.

Desenvolver uma Educação Profissional e Tecnológica com qualidade socialmente referenciada e que intencione a formação de sujeitos críticos, criativos e reflexivos, pressupõe a constituição de docentes com formação sólida e reflexiva; com perfil de professor pesquisador, com atuação em sala de aula ancorada na articulação e mediação do conhecimento, contribuindo para desenvolver nos jovens e adultos trabalhadores, habilidades necessárias para o trabalho, fortalecendo o domínio dos conhecimentos científicos, tecnológicos, histórico-sociais e principalmente a dimensão da formação humana. Para tanto, as ações de formação de professores para atuação na EPT devem ganhar novos contornos, compondo uma política pública duradoura e efetiva que promova a formação inicial e continuada e não apenas se configure como ações emergenciais, pontuais e dispersas. 


\section{REFERÊNCIAS}

[1] ARAÚJO, Ronaldo Marcos de Lima. Formação de Docentes para a Educação Profissional e Tecnológica: por uma pedagogia integradora da educação profissional. Revista Trabalho \& Educação, v.17, n.2, p.31-52, mai/ago. 2008. Disponível em:<http://www.portal.fae.ufmg.br/seer/index.php/trabedu/article/view/32>.Acesso em: mar. 2015.

[2] BAZZO, Walter Antônio. Ciência, Tecnologia e Sociedade: e o contexto da educação tecnológica. 5. ed. Florianópolis: ED. da UFSC, 2015.

[3] CONSELHO NACIONAL DE EDUCAÇ̃̃O. Câmara de Educação Básica. Parecer no 11, de 9 de maio de 2012. Diretrizes Curriculares Nacionais para a Educação Profissional Técnica de Nível Médio. Diário Oficial da União, Brasília, 4 set. 2012. Seção 1, p.98.

[4] _ _ MEC/SETEC. Documento Base da Educação Profissional Técnica de Nível Médio Integrada ao Ensino Médio. Brasília: MEC, 2007.

[5] _. Resolução no 2 de 01 de julho de 2015, MEC/CNE. Diretrizes Curriculares Nacionais em nível superior (cursos de licenciatura, cursos de formação pedagógica para graduados e cursos de segunda licenciatura) e para a formação continuada. Conselho Nacional de Educação do Distrito Federal. Brasília, 2015.

[6] FIGHERA, Adriana, JUCHEM, Luiza, SANTOS, Luciana. A Formação Pedagógica do Professor da Educação Profissional e Tecnológica. Campinas, 2012.

[7] MACHADO, Lucília Regina de Souza. O desafio da Formação de professores para a EPT e PROEJA. Campinas, Educ. Soc., 2011. V.32. N.116, p.689-704.

[8] _. Diferenciais inovadores na formação de professores para a educação profissional. Revista Brasileira da Educação Profissional e tecnológica. Ministério da Educação, secretaria de Educação Profissional e Tecnologia. V.1, n.1 (jun. 2008). Brasília: MEC, SETEC, 2008. Anual. Disponível em: <http://goo.gl/bPDvi7>. Acesso em Mai. 2015.

[9] PENA, Geralda Aparecida de Carvalho. Formação docente e aprendizagem da docência: um olhar sobre a educação profissional. Educação em Perspectiva, Viçosa, V.2, n.1, p.98-118, jan./jun. 2011. 


\section{Capítulo 18}

\section{Formação continuada: De quem, para quem?}

\section{Maria Elba Soares}

\section{Claudia Christina Bravo e Sá Carneiro}

Resumo: Este artigo tem sua gênese no conjunto de experiências vividas por docentes que atuam do Ensino Fundamental, anos finais, em relação ao processo formativo. Vivemos em um mundo imerso na informação globalizada e, nessa rede de conhecimentos, há saberes coerentes e outros sem veracidade, mas que são de fácil acesso e circulam rapidamente. Neste contexto, a educação tem papel fundamental para o enfrentamento desse tipo de situação e, principalmente o professor, precisa estar preparado. Neste sentido entendemos que a formação continuada pode consistir um mecanismo importante, capaz de permitir aos docentes o desenvolvimento de uma nova mentalidade, com práticas docentes inovadoras. Desse modo, pretendemos, apresentar as compreensões dos docentes acerca do valor e das suas aprendizagens em seu processo de formação continuada, junto a uma reflexão teórica. A investigação sobre a formação continuada dos docentes in lócu objetivou, perceber a compreensão de formação continuada de docentes do Ensino Fundamental, anos finais, refletindo sobre o que revelam de suas conquistas e dificuldades no percurso desta formação continuada. A pesquisa teve a abordagem qualitativa, utilizando técnicas da entrevista semiestruturada e questionários, aplicados a docentes que atuam no $6^{\circ}, 7^{\circ}$ e $8^{\circ}$ ano do Ensino Fundamental, series finais. As entrevistas evidenciam as narrativas dos docentes e os questionários foram complementares e importantes para a coleta de percepções específicas A discussão ancora-se teoricamente nos recorrentes debates e produções sobre o tema, presentes em congressos, pesquisas acadêmicas e artigos. Dessa forma em nosso estudo enxergamos que esse caminho exerce um ganho individual e coletivo na geração de novas atitudes e aprendizagens docentes.

Palavras-chave: Formação continuada; Prática docente, Reflexão. 


\section{INTRODUÇÃO}

No momento histórico em que vivemos, o conhecimento tem avançando freneticamente, bem como o número de pesquisas e de produção acadêmica na área educacional. Neste sentido, a Educação assume a função social de dar sentido, de ensinar a selecionar o conhecimento, enfim, de encontrar significado para o volume assustador de informações disponíveis. Para tanto, a formação continuada pode assegurar ao docente a possiblidade de aprender continuamente, de agir de forma comprometida com a educação cidadã. Em virtude desta realidade, torna-se primordial investir na formação continuada, visando a conexão dos conhecimentos científicos com os saberes pedagógicos, refletidos e compartilhados.

Esta multiplicação e circulação de informação trouxe maiores exigências para o papel do professor, o conhecimento tornou-se mais complexo e precisa envolver conceitos, valores e crenças para ser significativo. Neste sentido, entendemos que a formação continuada compreende uma tomada de consciência político-pedagógico que problematiza, analisa e recria a prática docente, bem como se constitui um processo de reflexão permanente das práticas assumidas pelo professor. Ressaltamos que nesta vertente a formação do professor necessariamente precisa integrar teoria e prática e refletir as questões didático-pedagógicas de forma integrada.

0 tema da formação continuada é discutido por vários autores que apresentam reflexões e pesquisas acerca da temática e da sua importância para a educação, como Candau (1997), Nascimento (2000), Pimenta (2002), Freire (1991) Gadotti (2003) Gatti (1997), Menga Lüdke (2001) e Altenfelder (2005). Os pesquisadores concordam que a formação continuada reflexiva, que faça uma ponte entre as ideias e a ação docente, será capaz de transformar a educação.

Entendemos que a escola é o espaço legítimo da formação continuada e que tem papel fundamental para o desenvolvimento dos saberes pedagógicos, teóricos e da experiência. Assim, formação continuada dentro da escola configura-se numa dinâmica de reuniões, estudos, troca de experiência, convivência e aprendizado. Compete, portanto, à instituição e ao professor articular essa dinâmica para a sistematização dos processos que demandam da formação continuada. Para Menga Lüdke (2001), o desenvolvimento do professor só se fará na integração dos saberes e com base na articulação entre teoria e prática educativas, num permanente diálogo com os sujeitos e com cada fato concreto do processo educacional e objetivando o desenvolvimento da sociedade.

Segundo Gadotti (2003) a ideia de formação permanente inicia-se pela reflexão crítica sobre a prática, sendo imprescindível examinar os múltiplos aspectos: as teorias, os procedimentos e os preconceitos. É necessário que a reflexão crítica alcance os sentidos políticos e ideológicos subjacentes à cada tipo de educação. Nesse sentido, a formação deve se basear em estudos críticos e reflexivos das ações através da troca de experiências entre pares, tais como: relatos de experiências, oficinas, mesas redondas e grupos de trabalho. Aprender junto significa dizer coletivamente o que ensinar e o que aprender e que cada um pode aprender com o outro.

Conforme Gatti (1997), vivemos num tempo em que a função social do ato de ensinar é entendida de forma ampliada e complexa, envolvendo as muitas interfaces do campo educacional, entre confrontos, sínteses e aprendizagens, este cenário exige que o professor reflita e reconstrua constantemente sua ação docente.

Dessa forma, a formação continuada torna-se um processo de crescimento permanente e engajamento profissional, educacional e social. Para Frigotto (1996) enfrentamos uma avassaladora crise social diante da atual política fragmentada e opressora que gera marginalidade social. Partindo do ideal de uma sociedade justa e inclusiva é preciso um novo profissional do ensino, que compreenda e assuma novas estratégia de ensino, reflexivo e crítico, que analise e reavalie sua prática e que esteja envolvido com a transformação da sociedade.

Concordando com esses pensamentos, as reflexões sobre formação continuada nos levaram à seguinte questão: como o docente compreende a sua formação continuada? Assim, o objetivo desta pesquisa é investigar a ideia de formação continuada apresentada por professores do Ensino Fundamental, anos finais.

Para esta pesquisa foi utilizada a abordagem qualitativa, empregando como técnicas de coleta de dados, entrevista semiestruturada, que foi realizada com 4 sujeitos e o questionário, aplicado a 10 professores,

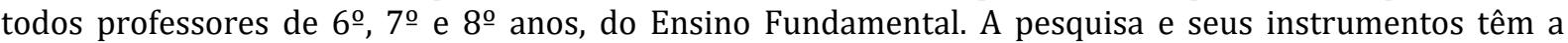
finalidade de refletir e analisar as diferentes percepções sobre formação continuada identificadas pelos sujeitos da pesquisa. Os sujeitos foram escolhidos observando o critério do tempo de experiência em sala de aula, ficando assim distribuído: 5 professores com até 5 anos de experiência em sala de aula e 5 com 
mais de 10 anos de experiência em sala de aula. Nas entrevistas foram 2 professores com até 5 anos de experiência em sala de aula e 2 com mais de 10 anos de experiência em sala de aula.

Dessa forma, nos propomos, nesta investigação, a interpretar os achados dessa pesquisa através do auxílio de autores que subsidiam o assunto, numa dinâmica em que a teoria ajudará a compreender melhor os elementos pesquisados.

\section{FUNDAMENTAÇÃO TEÓRICA}

É atribuído ao professor, na contemporaneidade, maior exigência sobre seus saberes, o desafio, portanto, consiste em ser um aprendiz permanente e colocar em prática essa exigência considerando a interrelação entre os saberes da pedagogia, da didática, dos conhecimentos curriculares e das novas tendências educacionais. Dessa forma Ninguém nasce educador ou marcado para ser educador. A gente se faz educador, a gente se forma, como educador, permanentemente, na prática e na reflexão da prática. (FREIRE, 1991: 58). Portanto, um projeto de formação continuada abre um leque de possibilidades para uma aprendizagem coletiva e de compartilhamento dos saberes da docência no espaço escolar.

A formação continuada favorece a permanente transformação da ação educativa, conferindo significado para o docente e para a escola. Candau (1997) apresenta um tripé para a formação continuada: primeiro, reconhecer a escola enquanto lócus privilegiado de formação continuada; segundo, valorizar o saber docente; e o terceiro é a aprendizagem constituída ao longo da carreira, ou seja, partindo da realidade escolar, valorizando o saber disciplinar e o saber da experiência e considerando o saber docente construído na prática pedagógica.

\section{QUAL CAMINHO TRANSFORMA A PRÁTICA?}

A formação docente continuada sofreu e sofre mudanças de concepções e nomenclatura no cenário educacional desde sua inclusão nas pesquisas e produções científicas. Altenfelder (2005), por exemplo, contribui nesta reflexão com sua pesquisa sobre tendências e desafios desse tipo de formação no Brasil.

No processo trilhado pela formação, algumas características demarcam cada tempo e concepção, dessa forma, faremos uma breve síntese dos modelos e nomenclaturas que constituíram a história dessa formação. Inicialmente um dos nomes dados foi o de reciclagem, que carrega a visão técnica voltada para uma ação acrítica e descontextualizada, sem contexto e a formação ocorria apenas em eventos. Outro nome que encontramos na literatura é treinamento, que nos fala de um processo de formação mecânico e meramente repetitivo, com o objetivo de moldar condutas e procedimentos, formando um professor acrítico, que só reproduz a sociedade desigual e classista.

Continuando a reflexão temos a designação aperfeiçoamento, que carrega o sentido de melhorar a pessoa, de concluí-la, nega a formação enquanto processo e acredita que educar é um caminho unilateral, não relacional.

Este conjunto de interfaces da formação continuada convergem para as tendências tradicional e tecnicista, que entendem o conhecimento fundamentado na repetição, mecanização da aprendizagem e reprodução da desigualdade social. A visão mecânica ocorre por meio da reprodução de modelos e padrões, sem refletir sua adequação e relação com o que se ensina, é apenas uma questão de aplicar tarefas, técnicas e dinâmicas. Estas abordagens visam o desenvolvimento de habilidades e atitudes sem que estas sejam integradas à capacidade reflexiva.

Seguindo a reflexão de Altenfelder (2005) outro movimento emerge sobre o termo Capacitação. Aqui a termologia não será tratada como convencimento e persuasão, mas na abordagem progressista, que envolve a ação de capacitar de dar o sentido ao que se faz, de tornar capaz para assumir com inteireza sua função de educador, apropriando-se de condições próprias à profissão, tornando-se capaz de pensar e agir de forma integrada.

Diante dos diversos de significados dados à formação do professor ao longo do tempo, trataremos aqui da terminologia formação continuada, numa abordagem mais ampla e progressista que engloba os aspectos a serem enfocados no processo de desenvolvimento profissional, permitindo a superação da fragmentação do conhecimento e do próprio sujeito. 


\subsection{A FORMAÇÃO CONTINUADA: UM ELO COM A TRANSFORMAÇÃO SOCIAL.}

A formação do professor tem seu início na licenciatura e, de acordo com Neto, Jacobucci \& Jacobucci (2007) um aspecto relevante é pensar os cursos de formação inicial como um elo fundante para formar o docente, visto que os currículos apresentam dificuldades tanto nos aspectos teóricos, quanto pedagógicos, bem como na organização fragmentada dos currículos, que separam e valorizam com pesos diferentes as disciplinas científicas das pedagógicas, o que irá sobrecarregar de responsabilidades a formação continuada numa perspectiva inovadora.

É importante destacar que a formação continuada tem sido, pela necessidade, vista como complemento da formação inicial. No entanto, é preciso frisar que o caráter primordial da formação continuada é ser um processo permanente (Nóvoa, 1997). Nesta perspectiva a formação continuada é impulsionadora de mudanças no próprio currículo das formações iniciais, num processo de retroalimentação e renovação de ambas as formações diante dos diferentes objetivos e propostas, mas buscando em ambas a abordagem progressista.

Assim, a concepção que o professor dará à sua prática terá sua gênese em suas formações, tanto na inicial quanto na continuada, integrando o que aprendeu ao longo de sua vida, portanto, as crenças e concepções aprendidas e os modelos que vivenciou. Com a formação inicial e continuada estas compreensões são questionadas e reavaliadas e, a partir da reflexão e da confrontação das velhas e novas abordagens da ação docente, o professor se auto avalia e refaz seu pensar e agir e, também, a forma com que concebe o conhecimento.

Segundo Carneiro (2008), a formação docente de profissionais da educação tornou-se uma prioridade, especialmente pela ampliação de oferta de vagas nas escolas versus a carência de docente para a educação básica, por isso a ideia de formação continuada alcança relevância do cenário educativo. A partir desta perspectiva, é necessário pensar na formação do professor sob sua globalidade e complexidade e, para Morin (2005), o paradigma da complexidade analisa os dados significativos e compreende os dados que não são significativos, bem como compreende os fenômenos. Assim, a formação continuada, passa a ser um elemento que fomenta o pensamento e a ação integrada e rompe com a inércia de um ensino tradicional e tecnicista, podendo oferecer um ensino de qualidade.

A formação continuada do professor está diretamente ligada à formação do aluno, visto que o professor reavalia e reorganiza seus saberes, formas de ensinar, crenças e valores. Garrido (1997) acredita que o primordial da educação escolar nos dias atuais é compartilhar com os alunos a capacidade de investigar, deduzir, comparar e sintetizar e, para tanto, é preciso que o professor viva antes estes passos, contextualizando seu próprio conhecimento.

A formação continuada é, portanto, um campo complexo que exige uma visão ampla, não podendo se restringir ao isolamento de saberes, não é suficiente formar o professor somente nos saberes do conteúdo da sua área de conhecimento; é preciso formar integrando os saberes filosóficos, pedagógicos e epistemológicos, o que trará um novo entendimento à condução docente.

\subsection{ANÁLISE DAS ENTREVISTAS E QUESTIONÁRIOS: LENDO E INTERPRETANDO OS DADOS}

A proposta de usar a entrevista semiestruturada e o questionário nesta pesquisa teve a intenção de conhecer a percepção dos docentes acerca da formação continuada. As entrevistas foram realizadas com 4 docentes e, os questionários, com 10 docentes, que mostraram-se receptivos e abertos para responder às questões. Para assegurar o anonimato dos docentes foi-lhes atribuído códigos: D1, D2, D3 e D4. Os docentes foram escolhidos observando o tempo de sua experiência em sala de aula, um grupo com ate'5 anos de experiência e outro com mais de 10 anos de experiência.

As questões orientadoras da entrevista e do questionário foram elaboradas como problematizações, a partir dos objetivos da pesquisa, como apontado a seguir. 


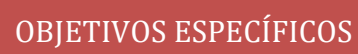
professores sobre a função da formação continuada.
ENTREVISTA SEMIESTRUTURADA
QUESTIONÁRIO

Qual a função da formação continuada?

( ) Organizar e animar situações de aprendizagem tendo em vista seus horários na escola e as demandas institucionais.

( ) Conceber e gerir situações de aprendizagem ajustadas ao currículo e possibilidades da escola.

Para você qual a função da Formação Continuada?

( ) Investir em aprendizagem continuada e no desenvolvimento pessoal e profissional para desenvolver a capacidade de autogestão profissional.

( ) Aprender a trabalhar em equipe e elaborar um projeto de equipe.

b) Pesquisar a compreensão dos professores sobre as vantagens e desvantagens da formação continuada.

c) Compreender a maneira como os professores entendem a relação da formação continuada com sua ação docente.

\section{0 que você destaca como} vantagens e, também, como desvantagem da formação continuada.
Liste as vantagens e desvantagens da formação continuada.

Qual a relação entre a formação continuada e sua prática em sala de aula?
Você acha importante a formação continuada? Porquê?

\subsection{CARACTERIZAÇÃO DOS DOCENTES ENTREVISTADOS}

Todos os entrevistados são licenciados, o docente D1 tem Licenciatura em Ciências Biológicas. Sua especialização é em Educação Ambiental e tem experiência de 15 anos lecionando em turmas do Ensino Fundamental, anos finais. O docente D2 é formado em matemática. Não tem especialização e tem experiência de 4 anos lecionando em turmas do Ensino Fundamental, anos finais. 0 docente D3 é formado em História, com especialização em Ensino de História, tem experiência de 20 anos lecionando em turmas do Ensino Fundamental, anos finais. 0 docente D4 é formado em Filosofia, está fazendo a especialização em Coordenação Pedagógica, tem experiência de 6 anos lecionando em turmas do Ensino Fundamental, anos finais.

\section{AS VOZES DOS DOCENTES.}

As questões que apresentaremos aqui, representam as vozes dos docentes reunidas através da pesquisa e as respostas mostram que há convergência sobre o interesse pela temática da formação continuada no contexto da escola, ponto relevante e destacado pelos sujeitos da pesquisa.

Analisando a percepção dos professores sobre a função da formação continuada, na entrevista semiestruturada e no questionário, ambos registados no quadro anterior, percebemos que a formação profissional é entendida como importante pelos professores. Destacam que é uma oportunidade de se atualizar de forma contínua e, também, que a formação ajuda no desenvolvimento da ação docente. Podemos inferir, portanto, que há uma concordância sobre a importância da função da formação continuada, que segundo Vasconcelos (1997) é através da formação continuada que o professor se liberta da autoridade do discurso alheio e forma o seu próprio com respaldo teórico e consistência na prática.

Acerca da compreensão dos professores sobre as vantagens e desvantagens da formação continuada percebemos que há um consenso quanto à cultura da aprendizagem que a formação envolve. Em contraponto, também é recorrente nas falas dos professores o acúmulo de trabalho e que, quando a formação exige que o professor leve mais demanda de leitura para casa, esta sobrecarga é vista como desvantagem. Portanto, entre as vantagens e desvantagens chegamos à reflexão sobre uma política de formação que, segundo Frigotto (1996), é preciso ressignificar a formação do professor no plano teórico e epistemológico, de forma a superar o conhecimento preso à lógica da produção e do mercado, essa relação tem consequência em concepções e práticas fragmentadas e etnocêntricas. 
A percepção dos professores sobre a função da formação continuada
Os entrevistados D1 e D4 destacaram que no início achavam a formação uma perda de tempo, mas que com o envolvimento e constância passaram a entender a proposta e a sentir seus efeitos em suas aulas.

O D2 destacou que há algumas propostas em que ele percebe uma função direta com sua prática, mas há outras em que não há relação nenhuma com a sala de aula.

O D3 apontou que entende a importância e que sempre se envolveu e aprendeu no processo de formação.
5 professores escolheram o item que defende a ideia da formação como investimento em aprendizagem continuada e no desenvolvimento pessoal e profissional para desenvolver a capacidade de auto-gestão profissional.

4 professores identificaram o item que destaca que a formação significa aprender a trabalhar em equipe e elaborar um projeto de equipe.

1 professor não marcou nenhum dos itens.

A partir dos 10 questionários formamos a seguinte lista de vantagens que foram citadas pelos professores.

Os professores D1 e D2 colocaram que a vantagem é quando as formações acontecem dentro do horário em que o professor está na escola. Como desvantagem ambos citam que alguns eventos sobrecarregam o professor com leituras extras.

A compreensão dos professores sobre as vantagens $\mathrm{e}$ desvantagens da formação continuada

O professor D3 colocou como vantagem a aprendizagem e a troca de conhecimento entre os colegas. Como desvantagem, o acúmulo de trabalho do professor, que o impede de focar nos estudos.

O professor D4 apontou como vantagem os momentos que os temas estão diretamente ligados à prática e como desvantagem quando os temas são somente teóricos.

Todos os entrevistados destacaram que

A maneira como os professores entendem a relação da formação continuada com sua ação docente
1. Aprimoramento do trabalho;

2. Estudar e trocar ideias com os colegas;

3. Aprender coisas novas que podemos levar para a sala de aula;

4. Conhecer os autores da educação.

As desvantagens citadas foram:

1. 0 acúmulo de trabalho do professor;

2. Textos e palestras que não têm relação com a sala de aula.

3. A não valorização dos profissionais da própria escola.

4. Poucos momentos para troca de experiências.

Todos os entrevistados concordaram que a formação é importante.

3 professores justificaram que é importante, porque o mundo hoje é outro e precisamos nos atualizar.

Outros 2 professores disseram que não tem tempo para fazer cursos, seminários e congressos e que através da formação continuada podem estudar.

2 professores disseram que é importante, por que é um momento de conversar sobre as teorias, os problemas e as possíveis soluções.

3 professores concordaram que é importante porque aprendem uns com os outros. 
A maneira como os professores entendem a relação da formação continuada com sua prática é numa relação de pertinência, que ora tem ligação direta com a sala de aula e ora os professores a veem como somente teórica, ou sem sentido para a ação docente. Dessa forma, a ideia da articulação entre teoria e prática, torna-se prioridade, já que, como salienta Pimenta (2002), não é possível negar que é imprescindível a reflexão na prática e sobre a prática para envolver os professores e compromete-los nos problemas enfrentados no fazer pedagógico.

\section{CONSIDERAÇÕES FINAIS}

A concepção atual da formação continuada representa uma nova ideia que expressa o saber integrado do professor e a valorização profissional, o que implica a interseção entre a prática, a reflexão e a valorização social e econômica da carreira do docente. Assim, a carreira docente precisa de uma séria política educacional.

Assim, a formação continuada reflexiva e política é um projeto contemporâneo, que objetiva renovar o cenário educacional, envolvendo várias nuances da ação docente, suas contradições e conquistas, seus saberes e desafios como foi apresentado pelas posições e colocações dos sujeitos da pesquisa, destacados na análise dos dados.

A nosso ver, a formação continuada corrobora sobremaneira para refletir a prática e recriá-la, tendo como suporte os saberes teóricos, as pesquisas, a criticidade e a troca constante de experiências, de tal modo que um programa de formação continuada promove mudanças e renovações no plano individual e coletivo. A vivência de novas experiências, os embates e debates das teorias e das práticas provocam e promovem novas formas de ver e pensar a ação docente e a escola.

\section{REFERÊNCIAS}

[1] ALTENFELDER,A. H. Desafios e tendências em formação continuada. Artigo: Construção psicopedagógica. Versão impressa ISSN 1415-6954. Constr. psicopedag. v.13 n.10 São Paulo, 2005. Disponível em pepsic.bvsalud.org/scielo. Acesso em agosto de 2012.

[2] CANDAU, Vera Maria (org). Magistério: construção cotidiana. Petrópolis, RJ: Vozes, 1997

[3] CARNEIRO, Claudia Christina Bravo e Sá. Ensino de Ciências e Formação Docente: reflexões e mudanças possíveis. Revista Linguagens, Educação e Sociedade. Revista do Programa de Pós-Graduação em Educação da UFPI. Disponível em: < http://www.ufpi.br/subsiteFiles/ppged/arquivos/files/Revista/revista_mestrado_19.pdf> Acesso em: 20 Mar. 2012.

[4] FREIRE, Paulo. Educação como Prática da Liberdade. Rio de Janeiro: Paz e Terra, 1991

[5] FRIGOTTO, Gaudêncio. A formação e profissionalização do educador: novos desafios. In: GENTILLI, P. e SILVA, T.T. da, (Orgs). Escola S.A. Brasília, CNTE, 1996.

[6] GADOTTI, Moacir. Saber aprender: um olhar sobre Paulo Freire e as perspectivas atuais da educação. In: LINHARES, Célia; TRINDADE, Maria. Compartilhando o mundo com Paulo Freire. São Paulo: Cortez: Instituto Paulo Freire, 2003.

[7] GATTI, Bernardete A. A formação de professores e carreira: problemas e movimentos de renovação. Campinas, SP: Autores Associados, 1997.

[8] JACOBUCCI, D. F. C.; JACOBUCCI, G. B.; MEGID NETO, J. A Formação Continuada de Professores em Centros e Museus de Ciências no Brasil. In: 30ª Reunião Anual da Associação Nacional de Pós-Graduação e Pesquisa em Educação -ANPEd, Caxambu, MG. Anais da 30ª Reunião Anual da Associação Nacional de Pós-Graduação e Pesquisa em Educação -ANPEd. Caxambu - MG (on line), 2007.

[9] LÜDKE, M. O professor, seu saber e sua pesquisa. Educação \& Sociedade, ano XXII, no 74, vol. 22, p. 77-96, abr. 2001.

[10] MORIN, E. Introdução ao pensamento complexo. Porto Alegre: Sulina, 2005.

[11] NASCIMENTO, M. das G. A formação continuada dos professores: modelos, dimensões e problemática. Ciclo de Conferências da Constituinte Escolar. Caderno Temático, Belo Horizonte, n. 5, jun., 2000.

[12] PIMENTA, Selma Garrido, (org.). Formação de Professores: identidade e saberes da docência. In. Saberes Pedagógicos e Atividade Docente. São Paulo: Cortez, 2002

[13] VASCONCELLOS, Celso dos Santos. Coordenação do trabalho pedagógico: do projeto político ao cotidiano da sala de aula. São Paulo: Libertad, 2006. 


\section{Capítulo 19}

\section{Formação continuada de professores: Desafios e dificuldades do exercicio da docência}

\section{Luiz Anselmo Menezes Santos \\ Sirleia Pereira Silva Gomes}

Resumo: A formação de professores vem sendo foco de interpretação de vários estudos e pesquisas nas últimas décadas. Nunca se falou tanto em formação de professores, como nos dias atuais. 0 conhecimento e a experiência profissional como lócus da prática educativa trazem, à tona, reflexões acerca das questões que permeiam a profissão docente. Os estudos sobre a formação docente implicam um conhecimento das relações humanas, considerando o professor como um profissional inserido num debate para além do campo de sua atuação. Podemos ver de forma sucinta que os professores passaram por fases de valorização e desvalorização; hoje conseguiram alcançar alguns objetivos que eram seus de direito, mas ainda falta muito a percorrer para que a Educação e o profissional do Magistério sejam valorizados como merecem. Ser professor talvez seja mais que uma profissão, pois ultrapassa toda e qualquer barreira do entendimento. 0 profissional do magistério deverá buscar sempre fazer o melhor para atingir os objetivos e principalmente se comprometer em melhorar o mundo, pois sua competência está na forma como irá atuar no desenvolvimento de um ser ainda em formação.

Palavras-Chave: Formação Continuada, Docência, Educação Básica, Profissão. 


\section{INTRODUÇÃO}

Estudar sobre a formação continuada é um problema que nos remete a uma gama variada de questões como: o exercício profissional, a qualidade de ensino, a identidade profissional e a razão de ser daquele se dedica ao ato de ensinar. Assim estaremos abordando os desafios e perspectivas do profissional do magistério ressaltando os princípios e as competências que devem fundamentar a prática docente.

A formação de professores vem sendo foco de interpretação de vários estudos e pesquisas nas últimas décadas. Nunca se falou tanto em formação de professores, como nos dias atuais. O conhecimento e a experiência profissional como lócus da prática educativa trazem, à tona, reflexões acerca das questões que permeiam a profissão docente. Os estudos atuais sobre a formação docente, ressaltam o conhecimento das relações humanas e consideram o professor como um profissional inserido num debate para além do campo de sua atuação.

Conhecer o professor, sua formação básica e como ele se constrói ao longo da sua carreira profissional são fundamentais para que se compreendam as práticas pedagógicas dentro das escolas. Entendemos que se tornar professor, é um processo de longa duração, de novas aprendizagens e sem um fim determinado Nóvoa (1999).

Dentro dessa perspectiva, a formação continuada, entendida como parte do desenvolvimento profissional que acontece ao longo da atuação docente, pode possibilitar um novo sentido à prática pedagógica, contextualizar novas circunstâncias e resignificar a atuação do professor. Assim, analisamos a formação continuada diretamente ligada ao papel do professor; as possibilidades de transformação de suas práticas pedagógicas e nas possíveis mudanças do contexto escolar. Tal prática está para além das atualizações científicas, didáticas ou pedagógicas do trabalho docente, supõe uma prática cujo alicerce é balizado na teoria e na reflexão desta, para mudança e transformação no contexto escolar.

Desta forma, a formação continuada contribui de maneira significativa para o desenvolvimento do conhecimento profissional do professor, cujo objetivo entre outros, é facilitar as capacidades reflexivas sobre a própria prática docente elevando-a a uma consciência coletiva. A partir dessa perspectiva, a formação continuada conquista espaço privilegiado por permitir a aproximação entre os processos de mudança que se deseja fomentar no contexto da escola e a reflexão intencional sobre as consequências destas mudanças.

Neste sentido, as formações iniciais e continuadas de professores vêm assumindo destaque cada vez maior nas discussões sobre educação. É uma preocupação que se evidencia nas reformas que vêm sendo propostas e, muitas vezes implementadas, nas políticas de formação docente no sistema educacional brasileiro, bem como nas investigações e publicações da área educativa e, ainda, nos debates acerca da formação inicial e continuada de professores.

\section{METODOLOGIA}

No presente artigo trate-se uma pesquisa bibliográfica acerca da produção acadêmica sobre a necessidade da formação continuada de professores. As escolas e as salas de aulas têm servido como locais para coleta de dados sobre padrões de comportamento dos professores, desta forma, esta pesquisa também busca abordar a relação do professor com o ambiente escolar, com seus alunos e com tudo que está ao seu redor e que o afeta direta e indiretamente.

As principais fontes de informações são: os ambientes físicos, os relatórios e documentações, os materiais usados, outros objetos e as pessoas diretamente envolvidas [...] Os resultados deste tipo de pesquisa são normalmente apresentados na forma de narrativas acrescidas de tabelas e ilustrações gráficas. (MOREIRA e CALEFFE, 2008, p. 78,79).

Para Moreira e Caleffe (1992), o ato individual da pesquisa não acontece em um vácuo, mas em um contexto social, isto é, ele acontece em uma comunidade de pesquisadores que possui ou compartilha de concepções similares em determinadas questões, métodos, técnicas e formas de explanações. Sendo assim, buscamos abordar um tema que vem sendo recorrente no contexto escolar, mas que não têm se dado muita importância a ele, decidimos estudar como a produção acadêmica vem se posicionando sobre a formação continuada os professores da educação básica.

Pesquisar é o ato pelo qual procuramos obter conhecimento sobre alguma coisa. [...] Contudo, num sentido mais estrito, visando a criação de 
um corpo de conhecimentos sobre um certo assunto, o ato de pesquisar deve apresentar certas características específicas. Não buscamos, com ele, qualquer conhecimento, mas um conhecimento que ultrapasse nosso entendimento imediato na explicação ou na compreensão da realidade que observamos. (GATTI, 2002, p. 9-10)

Por se tratar de um estudo específico acerca da atuação de profissionais da Educação Básica, entendemos que se trata de uma pesquisa Educacional, já que tem a intenção de aclarar e compreender uma temática específica no campo da educação formal. Portanto, procura-se desenvolver argumentos e perspectivas que constroem os fundamentos pedagógicos que embasam a formação continuada. Por essas razões, este estudo configura-se no âmbito das ciências humanas, como uma abordagem qualitativa.

\section{RESULTADOS E DISCUSSÃO}

Atualmente podemos assistir o empenho que as secretarias educacionais quanto a implantação de programas institucionais de formação continuada, preocupadas com as recorrentes inovações e necessidades, tanto do processo educativo como dos professores, para atender ao propósito de melhoria do processo educativo desenvolvido por escolas municipais e estaduais.

No entanto, percebe-se que, os efeitos nem sempre têm provocado alterações na prática docente. Uma das criticas mais frequentes feitas pelos professores aos processos de formação continuada, recai no fato dos processos serem planejados e planificados sem a participação deles. Assim a análise de necessidades de formação, como modalidade de formação continuada que envolve e co-responsabiliza os professores ao longo do processo de ação formativa, parece ser um dos mecanismos que faz dessa ação algo diferenciador para eles.

Nóvoa (1995) ressalta que a relação dos professores com o saber constitui um dos capítulos principais na história da profissão docente: os professores são portadores (e produtores de um saber próprio ou são apenas transmissores e reprodutores) de um saber alheio? O saber de referência dos professores é fundamentalmente científico ou técnico? O autor destaca que é na resposta a estas e muitas outras questões que se encontram visões distintas da profissão docente e, portanto, projetos contraditórios de desenvolvimento profissional.

Na visão tradicional sobre Formação de Professores, o professor é especializado no conhecimento específico da disciplina sob sua responsabilidade, sendo sua prática pouco valorizada. Entretanto, hoje, o professor não pode ser mais compreendido como um mero transmissor de conhecimentos, que exerce sua prática pedagógica de modo repetitivo, que traduz conhecimentos específicos e fragmentados, a partir do discurso científico das ciências da educação. Podemos, sim, concebê-lo como produtor de saberes, dado que os saberes provenientes da sua experiência devem ser considerados, quando analisada a sua competência profissional. Tal pressuposto encontra fundamento nas leituras e reflexões que realizamos a partir de Tardif (2002), que caracteriza o saber docente como múltiplo e pluriorientado por diversos saberes, originados dos saberes curriculares, das disciplinas, do exercício profissional e da experiência pessoal.

O professor, de acordo com as circunstâncias e contextos de e para o seu exercício profissional, interage constantemente com seus alunos e contextos envolvidos no processo ensino-aprendizagem. Essas experiências possibilitam-lhes construir conjuntos de saberes sobre cada um, os quais orientam suas práticas.

É necessário, entretanto, lembrar que esses saberes que têm por fonte sua experiência são influenciados pela organização institucional e que esta, ocasionalmente, contribui, por suas ações e normas (currículos, programas, planos etc.), para o distanciamento entre os saberes da própria experiência e os saberes obtidos em sua formação inicial ou continuada.

Podemos ver de forma sucinta que os professores passaram por fases de valorização e desvalorização; hoje conseguiram alcançar alguns objetivos que eram seus de direito, mas ainda falta muito a percorrer para que a Educação e o profissional do Magistério sejam valorizados como merecem de forma compromissada e respeitosa.

Ser professor talvez seja mais que uma profissão, pois ultrapassa toda e qualquer barreira do entendimento. 0 profissional do magistério deverá buscar sempre fazer o melhor para atingir os objetivos e principalmente se comprometer em melhorar o mundo, pois sua competência está na forma como irá atuar no desenvolvimento de um ser ainda em formação. 
É visivelmente perceptível a diferença entre o que sabe ensinar e aquele que somente tem domínio sobre os conteúdos, aquele que apenas domina os conteúdos só transmitirá o que conhece, mas no ensino ocorrem situaç̧ões inesperadas, que exigira além do domínio, o jogo de cintura o saber resolver problemas, que segundo Perrenoud, 2001, é um homem de situação que resolve qualquer situação.

Compreendendo que na sociedade atual o professor se torna cada vez mais, um elemento fundamental na mediação dos processos constitutivos da cidadania dos alunos, para que ocorram a superação do fracasso e das desigualdades escolares, repensar a formação desses profissionais revela-se uma das prioridades no início de milênio. (PERRENOUD, 2001,p.197).

Admitimos que, se, por um lado, o professor, como profissional, deve conhecer profundamente o conteúdo disciplinar sob sua responsabilidade e os referentes às ciências da educação, por outro, deve aprimorar esses conhecimentos "pelo" e "no" exercício de suas práticas cotidianas na escola. Assim sendo nos inspiramos em Cunha (1989), para dizer que o processo de formação de professores nunca acaba está sempre acontecendo; é como um ciclo que vai desde o ingresso do professor na escola, como aluno até o final de sua trajetória profissional.

Na verdade, ouvir os professores, detectar suas necessidades, as suas dúvidas, as suas preocupações e as suas expectativas em relação à formação continuada, nos parece ser um conjunto de atitudes que concorrem para facilitar e aprimorar essa mesma formação.

$\mathrm{Na}$ atualidade, o papel do professor extrapolou a mediação do processo de conhecimento do aluno, o que era comumente esperado. Ampliou-se a missão do profissional para além da sala de aula, a fim de garantir uma articulação entre a escola e a comunidade. 0 professor, além de ensinar, deve participar da gestão e do planejamento escolares, o que significa uma dedicação mais ampla, a qual se estende às famílias e à comunidade. (GASPARINI; BARRETO; ASSUNÇÃO, 2005, p. 191)

Os professores sofrem diariamente pressões da direção da escola, dos alunos, dos pais dos alunos e da família, e enfrentam inúmeros obstáculos para conseguirem realizar seus planos, tanto pedagógicos quanto pessoais, e essas pressões e obstáculos muitas vezes não são notados por quem os cercam, o que acaba deixando o professor desmotivado, sem expectativas devido à desvalorização que é dada a sua profissão.

Segundo Gasparini et al (2005) torna-se pertinente defender que o sistema escolar transfere ao profissional a responsabilidade de cobrir as lacunas existentes na instituição, a qual estabelece mecanismos rígidos e redundantes de avaliação e contrata um efetivo insuficiente, entre outros, que acabam sobrecarregando o trabalho docente.

$\mathrm{Na}$ atualidade, o papel do professor extrapolou a mediação do processo de conhecimento do aluno, o que era comumente esperado. Ampliou-se a missão do profissional para além da sala de aula, a fim de garantir uma articulação entre a escola e a comunidade. 0 professor, além de ensinar, deve participar da gestão e do planejamento escolares, o que significa uma dedicação mais ampla, a qual se estende às famílias e à comunidade. (GASPARINI; BARRETO; ASSUNÇÃO, 2005, p. 191)

Tardif (2002) destaca que na medida em que um dos objetivos do professor é criar condições que possibilitem a aprendizagem de conhecimentos pelos alunos, num contexto de interação com eles, a gestão da matéria torna-se um verdadeiro desafio pedagógico, fazendo com que o professor transforme a matéria que ensina, para que possa ser compreendida e assimilada pelos alunos.

É verdade que o conhecimento pedagógico do conteúdo a ser ensinado não pode ser separado do conhecimento desse conteúdo. Entretanto, conhecer bem a matéria que se deve ensinar é apenas uma condição necessária, e não uma condição suficiente, do trabalho pedagógico. (TARDIF, 2002, p. 120)

Podemos perceber que o conteúdo a ser ensinado deve ser transformado, e até mesmo adaptado para cada tipo de aluno, para que todos o compreendam em grupo e individualmente. Para Tardif (2002) ensinar é perseguir fins, finalidades, ou seja, é empregar determinados meios para atingir certas finalidades. 
[...] o professor precisa, o tempo inteiro, reajustar seus objetivos em função da tarefa que está realizando e de todas as suas limitações temporais, sociais e materiais. Nesse sentido, seus objetivos de trabalho dependem intimamente de suas ações, decisões e escolhas. Levando em conta os objetivos escolares, pode-se dizer que a pedagogia é uma tecnologia constantemente transformada pelo trabalhador, que a adapta às exigências variáveis da tarefa realizada. (TARDIF, 2002, p. 127)

Segundo Tardif (2002) o ensino é uma atividade humana, um trabalho interativo, ou seja, um trabalho baseado em interações.

Concretamente, ensinar é desencadear um programa de interações com um grupo de aluno, a fim de atingir determinados objetivos educativos relativos à aprendizagem de conhecimentos e à socialização. (TARDIF, 2002, p. 118)

Os professores têm diversos grupos de alunos para ensinar, porém não podem deixar de levar em consideração que dentro desses grupos existem as diferenças individuais, e que a aprendizagem também é individual.

Quando se ensina, certos alunos parecem simpáticos, outros não. Com certos grupos, tudo caminha perfeitamente; com outros, tudo fica bloqueado. Uma boa parte do trabalho docente é de cunho afetivo, emocional. Baseia-se em emoções, em afetos, na capacidade não somente de pensar nos alunos, mas igualmente de perceber e de sentir suas emoções, seus temores, suas alegrias, seus próprios bloqueios afetivos.

(TARDIF, 2002, p. 130)

Segundo Tardif (2002) o problema principal do professor em interagir com alunos que são todos diferentes uns dos outros e, ao mesmo tempo, em atingir objetivos próprios a uma organização de massa baseada em padrões gerais, para ele embora o professor trabalhe em grupos, deve também agir sobre os indivíduos.

0 professor acaba se ligando afetivamente e emocionalmente com seus alunos, o que acaba fazendo com que não desempenhe apenas seu trabalho, mais também se empenhe e invista no trabalho a sua individualidade.

A pedagogia não pode ser outra coisa senão a prática de um profissional, isto é, de uma pessoa autônoma, guiada por uma ética do trabalho e confrontada diariamente com problemas para os quais não existem receitas prontas. Um profissional do ensino é alguém que deve habitar e construir seu próprio espaço pedagógico de trabalho de acordo com limitações complexas que só ele pode assumir e resolver de maneira cotidiana, apoiado necessariamente em uma visão de mundo, de homem e de sociedade. (TARDIF, 2002, p. 149)

Segundo Carlotto (2010) a profissão do professor antes considerada uma profissão vocacional, onde se havia satisfação para exercê-la, hoje se tornou uma profissão de bastante exigências e cobranças, sem seu devido reconhecimento, levando o professor a serem considerados mais técnicos que profissionais. A educação durante muitos anos se preocupou com questões pedagógicas e com a formação docente, e só na atualidade vem se dedicando ao professor. Tentando entender os sentimentos, as formas de vivenciar a profissão e os pontos de desgaste da profissão docente.

A formação Continuada de professores, concebida na forma de qualificação profissional de professores, necessita reconhece a dinamicidade da profissão docente, cuja identidade profissional é construída socialmente através de ações coletivas e interações com outros grupos e entidades.

Nessa perspectiva, "tornar-se professor" constitui um processo complexo, dinâmico e evolutivo, que compreende um conjunto variado de aprendizagens, saberes e experiências a serem adquiridas ao longo de diferentes etapas formativas. Desse modo, a formação continuada procura desencadear a construção de saberes necessários ao exercício profissional, aliando-se aos saberes advindos da própria experiência.

A prática pedagógica capaz de articular a teoria e a prática busca proporcionar meios de percepção de problemas inerentes ao processo ensino-aprendizagem. Além disso, destaca a preocupação em fomentar o 
desenvolvimento de competências em horizontes amplos, pautada em pressupostos articulados de concepções da profissão docente, do ato pedagógico e da própria formação profissional.

No momento em que a profissão docente é concebida como uma ocupação de caráter intelectual, que requer uma formação longa de ensino, pesquisa e extensão, a concepção do ato pedagógico baseia-se na construção do docente, estruturada a partir da análise que ele faz do real, dos conhecimentos teóricos adquiridos na sua formação e de conhecimentos práticos adquiridos em sua ação.

Os maiores problemas e dificuldades na organização da formação continuada incluem falta de verbas, dificuldade para liberação do professor, falta de local, horários incompatíveis, falta de infra-estrutura espacial e didática, falta de articulação entre universidade e escola, desmotivação do professor, dificuldade de avaliar a prática pedagógica. Podem, ainda, ser citadas discordâncias com o objetivo da formação continuada entre o professor e as agencias formadoras, bem como o estabelecimento da relação entre teoria e pratica.

A formação continuada é uma exigência para os tempos atuais. Desse modo, pode-se afirmar que a formação docente acontece em continuum, iniciada com a escolarização básica, que depois se complementa nos cursos de formação inicial, com instrumentalização do professor para agir na pratica social, para atuar o mundo e mercado de trabalho; continua ao longo da carreira do professor pela reflexão constante sobre a prática, continuidade de estudos em cursos, programas e projetos. (ROMANOWSKI, 2007, P.137-138)

A formação de professores deve ser concebida como um processo permanente e contínuo que abrange todo o percurso profissional. Essa formação progressiva é justificada tanto pela natureza humana da profissão docente quanto pela dinâmica e complexidade do sistema educativo. De fato, o professor não é um produto acabado, mas um indivíduo que se encontra em contínua formação, num processo permanente de desenvolvimento profissional.

Ressalte-se, porém, que a implantação dessas perspectivas necessita da apropriação de instrumentos metodológicos e conceituais que possam conduzir à direção objetivada. Caso contrário, restará apenas o discurso vazio, sem forças para alterar a realidade. Nesse sentido, formar professores significa formá-los para intervirem na escola, na vida social e, consequentemente, nas determinações colocadas pelo contexto mundial.

Entendemos que nas práticas docentes estão contidos elementos extremamente importantes, tais como a problematização, a intencionalidade para encontrar soluções, a experimentação metodológica, o enfrentamento de situações de ensino complexas, as tentativas mais radicais, mais ricas e mais sugestivas de uma didática inovadora, que ainda não está configurada teoricamente. Essa vasta e complexa produção tende a ficar perdida, diluída e ao nível do senso comum. (PIMENTA, 2008, p. 7)

Intervir no mundo exigirá do docente o domínio de conhecimentos acerca da realidade e de suas conexões internas, bem como das competências para solucionar determinadas situações circunscritas ao mundo real, em especial aquelas que podem garantir uma intervenção na aprendizagem do aluno, na escola, na educação e na vida cotidiana, enfim, nos lugares historicamente situados e perspectivados por transformações.

Diante desse quadro, construir competências significa contrapor-se ao modelo de competências no sentido instrumental e pragmático, como preveem as Diretrizes Curriculares Nacionais, para implementar uma ação educativa e pedagógica fundada nas diversas relações que o professor estabelece com os outros, e em especial com seus alunos no interior da escola, centrando-se na busca de significados que possam contribuir para a construção de um mundo melhor e dedicado à humanidade do sujeito social.

Possuir competências significa dominar as ações da docência em sentido particular e relacional entre professor e aluno, tendo em mente o estabelecimento de relações de aprendizagem voltadas para o pensamento crítico, autônomo, livre e dedicado ao bem-estar humano. 


\section{CONCLUSÕES}

O modelo atual de formação exigirá de qualquer docente, que atuará na Educação Básica, um posicionamento diante da realidade e de suas conexões internas, bem como a tomada de decisões para solucionar determinadas situações nos lugares historicamente situados e perspectivados por transformações. Ser um educador consiste em agir no mundo, tomando como ponto de partida a realidade em que se vive, seus problemas, suas particularidades e suas articulações com o todo, para então construir efetivamente as novas possibilidades de alteração da realidade.

Portanto, é importante que todo professor tenha conhecimento a respeito das diferentes necessidades sociais, e principalmente ter consciência de seu papel enquanto educador, sendo capaz de propiciar contribuições para o desenvolvimento humano. Investir no estudo sobre a compreensão destes processos já é um grande passo para o respeito às diferenças culturais. Garantir uma educação de qualidade a todos e propiciar aos educandos um nível de aprendizagem de forma permanente, sem desigualdades, sem exclusão social, é um desafio imenso que precisa ser perserguido em longo prazo sem as amarras das perspectivas imediatas.

\section{REFERÊNCIAS}

[1] ALVARADO-PRADA, Luis Eduardo, FREITAS, Thaís Campos, FREITAS, Cinara Aline Formação continuada de professores: alguns conceitos, interesses, necessidades e propostas. IN: Rev. Diálogo Educ., Curitiba, v. 10, n. 30, p. 367-387, maio/ago. 2010

[2] CUNHA, M. I. da. O professor e a sua prática. Campinas, São Paulo: Papirus, 1989. GASPARINI, Sandra M.; BARRETO, Sandhi M.; ASSUNÇÃO, Ada Á. O professor, as condições de trabalho e os efeitos sobre sua saúde. Educação e Pesquisa. São Paulo, v. 31, n. 2, p. 189-199, maio/ago. 2005.

[3] GATTI, B. A. A construção da pesquisa em educação no Brasil. Brasília: Plano Editora, 2002. Série Pesquisa em Educação, v. 1.

[4] MOREIRA, Herivelto; CALEFFE, Luiz g. Metodologia da pesquisa para o professor pesquisador. 2ed. Rio de janeiro: Lamparina, 2008. p 69-94

[5] NÓVOA, A.. Profissão: Professor, Porto, Porto Editora, 2ª ed., 1995.

[6] NÓVOA, A. (Org). Os professores e a sua formação. Portugal: Porto, 1992.

[7] RODRIGUES, A.; ESTEVES, M. A análise de necessidades na formação de professores. Porto, Porto Editora, 1993. (Coleção Ciências da Educação).

[8] SILVA, M.O.E. A análise de necessidades de formação na formação contínua de professores: um caminho para a integração escolar. Tese de Doutorado, USP, São Paulo, 2000.

[9] PERRENOUD, P. Formação de professores profissionais: Quais estratégias? Quais competências? 2ª ed. Porto Alegre: ARTMED, 2001.

[10] PIMENTA, Selma Garrido. Epistemologia da prática res-significando a Didática. In: ENCONTRO NACIONAL DE DIDÁTICA E PRÁTICA DE ENSINO (ENDIPE): Trajetórias e processos de Ensinar e Aprender: Lugares, Memórias e Culturas, 14., 2008, Porto Alegre. Anais... Porto Alegre: EDIPUCRS, 2008.

[11] ROMANOWSKI, Joana Paulin. Formação e profissionalização docente. 3 ed. rev. E atual. Curitiba: Ibpex, 2007.

[12] SOUZA, Régis Luíz Lima de. Dissertação: Formação continuada dos professores e professoras do município de Barueri: compreendendo para poder atuar; orientação Maria do Carmo Santos Domite. São Paulo: s.n., 2007. 244 p.: il. FE/USP.

[13] TARDIF, M. Saberes docentes e formação profissional. 3. ed. Petrópolis: Vozes, 2002. 


\section{Capítulo 20}

\section{A formação continuada de professores nas representações sociais dos formadores}

\section{Renata da Costa Lima}

Maria da Conceição Carrilho de Aguiar

Resumo: A frequência com que a formação continuada de professores tem sido reduzida ou tratada como sinônimo de capacitação, de treinamento, de aperfeiçoamento, de atualização, entre outros termos, foi o que nos motivou para a realização de uma pesquisa no intuito de compreender quais representações sociais de formação continuada são compartilhadas por seus formadores. Tomamos como categoria central a formação continuada de professores. Essa categoria foi compreendida a partir da teoria das representações sociais, tendo como suporte teórico e metodológico as considerações de Moscovici (1978; 2003), de Sá (1998) e de Abric (1994; 1998). Para atingir os objetivos propostos buscamos no Centro de Estudos em Educação e Linguagem (CEEL) os formadores colaboradores deste estudo. Como procedimento metodológico, a pesquisa contou com duas etapas, quais sejam: a aplicação de um teste de associação livre com vinte formadores e a realização de uma entrevista semiestruturada com dez formadores, elaborada a partir das respostas ao teste de associação, no intuito de aprofundarmos a compreensão das representações sociais do objeto formação continuada. Os achados do teste de associação livre revelaram que os formadores representam a formação continuada de professores como um momento de curso e isso reduz a complexidade da formação continuada, uma vez que ela se estende por toda a vida profissional do professor e não se resume a um curso específico. Percebemos, com o teste de associação e com a entrevista semiestruturada, um reducionismo da formação continuada quando ela é tratada pelos formadores participantes da pesquisa como uma capacitação, um treinamento, um aperfeiçoamento, uma atualização, entre outros termos, e, desta maneira, os formadores desconsideram a dimensão individual do processo de formação.

Palavras-chave: Formação continuada. Professores. Representação social. 


\section{INTRODUÇÃO}

Capacitação, aprimoramento, aperfeiçoamento, atualização, reciclagem ou formação continuada de professores? Todos esses termos, em um primeiro momento, parecem se referir à mesma coisa: formar professores. Não é raro encontrarmos nos discursos de professores, coordenadores, gestores e autores a redução da formação continuada a um momento de capacitação, aprimoramento, etc. Mas, o que de fato significa formar continuadamente professores? Um momento de capacitação, aperfeiçoamento, etc., esgota o que a formação continuada é ou deveria ser?

Sob os mais variados olhares e perspectivas, a formação continuada de professores tem adquirido um grande espaço nas pesquisas em educação. No entanto, muitas vezes a formação continuada tem sido utilizada de forma inadequada, confundindo-se com reciclagem, conferências pedagógicas, treinamentos, capacitação, atualização, entre outros termos. Mesmo quando esses formatos assumem "funções bem específicas em termos objetivos, conteúdos e tempo de duração [...] todos têm como elementos constitutivos a ausência de mecanismos efetivos para acompanhar a prática docente concreta dos professores" (FREITAS, 2007, p. 25).

Diante disso, em um primeiro momento, nos propomos a refletir sobre o que significa formação continuada, trazendo alguns elementos que entendemos ser essenciais para que ela se constitua enquanto formação - e não apenas um treinamento, atualização, reciclagem, etc. Em um segundo momento apresentamos os achados da pesquisa, na qual buscamos compreender como a formação continuada é representada por seus formadores.

Além de contribuir com o debate acerca do tema da formação continuada de professores, a relevância do estudo reside no fato de compreendermos a pessoa do formador como um agente essencial no processo de (re)significação, (re)configuração e (re)conceitualização da formação continuada, no contexto das representações sociais, bem como de acreditarmos que as representações dos formadores servem de guias de condutas para eles orientarem as suas práticas relativas aos professores que formam. Para tanto, a teoria das representações sociais se apresentou como suporte teórico-metodológico para a pesquisa que realizamos com os formadores.

Moscovici, pioneiro na teoria das representações sociais, preocupou-se em compreender como as representações se organizam, particularmente, no psicológico de um indivíduo. Ele afirmou que representar não é simplesmente repetir uma coisa ou reproduzi-la, mas reconstituí-la, retocá-la, transformá-la (MOSCOVICI, 1978).

Em contribuição ao debate, Abric (1994, p. 28) afirma que, em resumo, "a representação social funciona como um sistema de interpretação da realidade que rege as relações dos indivíduos com o seu meio físico e social, determinando seus comportamentos e suas práticas". 0 Autor ainda propõe uma abordagem estrutural das representações sociais, afirmando que uma representação é dividida em um núcleo central e nos elementos periféricos. 0 primeiro é a parte mais estável da representação. É o núcleo central que irá opor-se à mudança, pois toda alteração no núcleo central acarretará uma mudança completa da representação. Já os elementos periféricos se organizam em volta do núcleo central e possuem três funções essenciais: a de concretização, que possibilita a formação da representação em termos concretos; a de regulação, que possibilita a integração de uma nova informação ou transformações que ocorrem no meio ambiente, visto que o núcleo central não é vulnerável às mudanças; a de defesa, que é responsável pela defesa da representação em relação às mudanças (ABRIC, 1994).

Para Almeida (2005), os elementos periféricos e centrais de uma representação social permitem constatar que ela é ao mesmo tempo estável e instável, rígida e flexível, e é tanto consensual quanto marcada por fortes diferenças interindividuais.

Ressaltamos que quando decidimos realizar um estudo em representações sociais, o que queremos pesquisar é algum fenômeno de representação social. Certamente um fenômeno que despertou o nosso interesse em função de sua relevância social ou acadêmica. Contudo, uma vez escolhido tal fenômeno para pesquisar, o objeto não fica com isso automaticamente estabelecido (SÁ, 1998).

Sá (1998) afirma que um fenômeno de representação social não é equivalente ao objeto de pesquisa. É necessário transformar o fenômeno de representação em objeto de pesquisa, que, por sua vez, é uma construção que se dá desde a identificação do fenômeno, passando pela escolha de um desdobramento da teoria ou simplesmente escolher aquela inaugurada por Moscovici, até o percurso metodológico. No entanto sem perder de vista que as escolhas (do desdobramento, do percurso metodológico) precisam ser feitas a partir do objeto de pesquisa, ou seja, precisam estar a serviço do objeto, ajudando-o na sua compreensão. 
Por fim, só se pode falar em representações sociais delimitando um grupo de sujeitos específico, pois ao mesmo tempo em que uma representação é individual, ela também é coletiva e se constitui mediante um grupo, uma vez que uma representação reside na dialética entre o individual e o coletivo. Logo, a escolha pelos formadores do centro de estudos em educação e linguagem (CEEL) não foi aleatória. Optamos pelo CEEL e pelos formadores que lá atuam por entendermos que se trata de um centro com forte atuação na área de formação continuada de professores em nível nacional.

\section{A FORMAÇÃO CONTINUADA DE PROFESSORES: EM BUSCA DE UM CONCEITO}

Termos utilizados, como treinamento, capacitação, reciclagem, etc., reduzem a construção da autonomia intelectual do professor, pois se fundamentam em propostas previamente elaboradas a serem apresentadas aos professores no intuito de que as implementem nas salas de aula, obedecendo à lógica de cursos padronizados criados e pensados por experts para um grupo de "pobres e ignorantes professores" (CHRISTOV, 2002).

Segundo Aguiar (2004), os termos treinamento, aperfeiçoamento, capacitação e reciclagem desenvolveram-se no Brasil com o golpe militar de 1964, no período do modelo autoritário, para atualizar os professores sobre as mudanças no sistema educacional. A utilização desses termos na educação produzia a sensação de estar numa indústria treinando os operários para manusear máquinas. Assim, termos como treinamento e reciclagem significam preparar o indivíduo para os conhecimentos, habilidades e atitudes que irão maximizar a competência individual, com vistas a melhorar o desempenho da organização.

Ressaltamos que é necessário ter cuidado com a utilização de tais termos, dado que eles podem ser reducionistas em relação a toda a complexidade que envolve a formação continuada.

Resende e Fortes (2005, p.05) afirmam que as

percepções acerca da formação continuada de professores são muitas, o que provoca a utilização de conceitos e termos considerados similares, porém muitas vezes ambíguos e imprecisos, tais como capacitação, treinamento, aperfeiçoamento e reciclagem. Todos eles respondem a tendências diferenciadas.

Segundo os autores acima, existem distinções entre esses diferentes termos: reciclagem dá a ideia de mudanças profundas que desconsideram os saberes já existentes; treinamento indica destreza, exercício repetitivo e condicionante; capacitação sugere apenas o desenvolvimento de habilidades; aperfeiçoamento dá a entender completude e acabamento; já o termo formação implica um processo de construção inacabável.

A formação continuada não deve ser confundida com ações pontuais ou extensivas de formação, pois os efeitos são bastante limitados. A formação continuada, na visão do desenvolvimento profissional, implica,

além dos mecanismos de acompanhamento da prática docente, uma avaliação periódica das ações desenvolvidas e uma identificação das demandas de formação, localizadas com base nas dificuldades expressas pelos próprios professores no exercício de sua atividade profissional (FREITAS, 2007, p.25).

A formação continuada que defendemos é compreendida como um processo complexo e multideterminado que ganha materialidade em múltiplos(as) espaços/atividades, não se restringindo a cursos e/ou treinamentos, estimula a busca de outros saberes e introduz uma fecunda inquietação contínua com o já conhecido, motivando viver a docência em toda a sua imponderabilidade, surpresa, criação e dialética com o novo (PLACCO; SILVA, 2002).

Assim pensada e desenvolvida, a formação continuada envolve duas questões fundamentais no processo de constituição do sujeito que é/está sendo formado: a individualidade e a coletividade. Ela não pode ser reduzida a um tempo e espaço convencionais de formação, muito embora os momentos de formação no coletivo sejam de extrema importância para a formação do professor - e, em hipótese alguma, estamos negando as contribuições que esses momentos em coletivo podem dar aos professores.

Outra questão importante é apontada por Nóvoa (1992). O autor sugere que a formação continuada esteja fundamentada na experiência profissional, porém não se deve ficar nos saberes da experiência, é preciso um trabalho reflexivo e crítico sobre a prática. 
Concordando com Nóvoa (1992), ressaltamos a importância do enfoque teórico nas formações continuadas, embora seja comum que na formação continuada as reflexões estejam apenas ao nível da experiência, e as discussões teóricas sejam esquecidas, deixando a formação apenas no âmbito das experiências compartilhadas. Ressaltamos o valor tanto dos saberes da experiência dos professores em formação - pois a formação continuada precisa partir da realidade destes e dos problemas reais de cada contexto - quanto da discussão da teoria nos momentos da formação, porquanto o enfoque apenas num desses aspectos (saberes da experiência ou discussões teóricas) empobrece a formação.

\section{PERCURSO METODOLÓGICO}

A escolha de uma metodologia, tanto de coleta quanto de análise, segundo Abric (1994), está determinada por considerações empíricas - natureza do objeto, sujeitos, limitação das situações, etc.-, mas também se apoia no sistema teórico que justifica a pesquisa. Para esse autor há três objetivos que implicam uma abordagem multimetodológica das representações, organizadas em três tempos sucessivos: o encontro do conteúdo da representação; o estudo das relações entre os elementos, de sua importância relativa e de sua hierarquia; a determinação do controle do núcleo central.

Esta pesquisa contou com a participação de vinte formadores do CEEL. 0 critério de escolha foi pertencer ao grupo de formadores e estar disponível a colaborar com a pesquisa.

Realizamos um teste de associação livre com os vinte formadores, que consistiu em apresentar uma expressão indutora - formação continuada - que funcionou como termo indutor, correspondendo ao objeto de representação que está sendo investigado, para assim, solicitar ao sujeito a produção, o mais rapidamente possível, de no mínimo três palavras/expressões que lhe vierem à mente.

Posteriormente, com o intuito de aprofundar e obter mais elementos que nos ajudassem na compreensão das representações sociais de formação continuada, realizamos uma entrevista semiestruturada com uma porcentagem de $50 \%$ dos formadores que antes realizaram o teste de associação.

A análise do conteúdo do teste foi feita a partir da proposta de Bardin (2004). Para a autora, a análise do conteúdo do teste de associação se faz por meio da reunião da lista de palavras suscitadas por cada palavra/expressão indutora, sendo este primeiro trabalho de classificação. Assim, nos vemos diante de um confronto com um conjunto heterogêneo de unidades semânticas. Diante desta desordem, torna-se necessário introduzir uma ordem. Após acharmos uma ordem para essas palavras/expressões, as informações tornam-se acessíveis e manejáveis, de modo a chegarmos às representações, chamadas por Bardin (2004) de representações condensadas.

Com base nas respostas obtidas com o teste de associação livre, estabelecemos um critério de escolha dos formadores: entrevistar os que tivessem mencionado em sua resposta ao teste as palavras com maior frequência, dado que elas possivelmente se constituem como núcleo central de uma representação e, assim, teríamos mais elementos para compreendê-la.

0 roteiro da entrevista foi elaborado a partir das respostas ao teste de associação, no intuito de aprofundarmos a compreensão das representações sociais do objeto formação continuada.

Nas entrevistas o primeiro passo no sentido de interpretá-las foi transcrevê-las. Arruda (2005) aponta que a escuta e a transcrição das gravações são uma boa ocasião para mergulhar no material coletado. 0 segundo passo foi a leitura flutuante proposta por Bardin (2004). 0 terceiro passo, já após várias leituras das entrevistas, foi criar as categorias, o que de acordo com Franco (2008) é o ponto crucial na análise de conteúdo. Portanto, nossas categorias criadas a partir dos dados da entrevista são categorias empíricas, uma vez que foram construídas a partir do conteúdo das falas dos participantes.

\section{RESULTADOS E DISCUSSÕES}

\subsection{PERFIL DOS SUJEITOS}

A grande maioria dos participantes foi composta pelo sexo feminino - dezenove mulheres e apenas um homem. No que se refere à faixa etária, encontram-se entre vinte e sessenta anos.

A graduação é representada em sua maioria por pedagogos e psicólogos, mas também participaram fonoaudiólogos e licenciados em letras. 
Para ser formador do CEEL, é necessário estar cursando no mínimo o mestrado. Logo, os nossos sujeitos, obrigatoriamente, já o fizeram ou o estão cursando. Dos vinte participantes, treze cursaram ou cursam doutorado em educação e apenas um na área de linguística. Dos vinte sujeitos, apenas dois possuem pósdoutorado.

\subsection{TESTE DE ASSOCIAÇÃO LIVRE DE PALAVRAS}

\begin{tabular}{|c|c|c|}
\hline Palavras & Frequência & Porcentagem \% \\
\hline Reflexão & 13 & $65 \%$ \\
\hline Troca de saberes & 8 & $40 \%$ \\
\hline Aperfeiçoamento & 5 & $25 \%$ \\
\hline Capacitação & 5 & $25 \%$ \\
\hline Estudo & 4 & $20 \%$ \\
\hline Aprender & 3 & $15 \%$ \\
\hline Avaliação & 3 & $15 \%$ \\
\hline Construção coletiva & 3 & $15 \%$ \\
\hline Contínua & 3 & $15 \%$ \\
\hline Planejamento & 3 & $15 \%$ \\
\hline Ampliação dos saberes & 2 & $10 \%$ \\
\hline Aprofundamento & 2 & $10 \%$ \\
\hline Busca & 2 & $10 \%$ \\
\hline Compromisso & 2 & $10 \%$ \\
\hline Melhoria & 2 & $10 \%$ \\
\hline Motivação & 2 & $10 \%$ \\
\hline Necessária & 2 & $10 \%$ \\
\hline Novos saberes & 2 & $10 \%$ \\
\hline Prática & 2 & $10 \%$ \\
\hline Sistematicidade & 2 & $10 \%$ \\
\hline Saber teórico & 2 & $10 \%$ \\
\hline
\end{tabular}

Fonte: dados organizados pelas autoras com base no teste de associação livre de palavras.

Observando a tabela, nota-se que foram associadas vinte palavras/expressões ao termo formação continuada com frequência igual/superior a dois. A partir das palavras associadas, observamos que os formadores apontam apenas elementos positivos quando solicitados a associar palavras/expressões. Dividimos as palavras em duas categorias: 


\begin{tabular}{|c|c|}
\hline 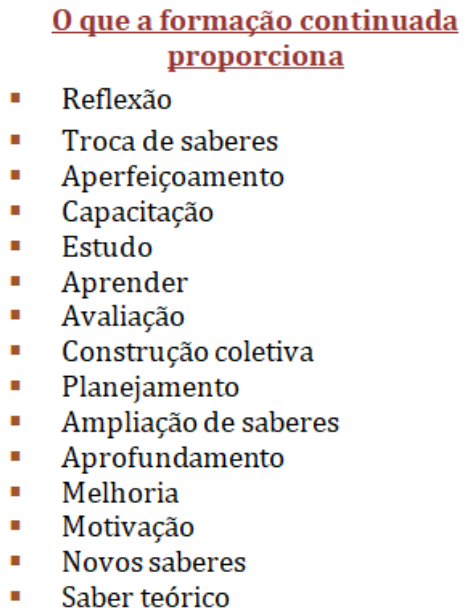 & $\begin{array}{l}\quad \frac{\text { Elementos que caracterizam a }}{\text { formação continuada }} \\
\text { - } \quad \text { Sistematicidade } \\
\text { - Necessária } \\
\text { - Prática } \\
\text { - } \text { Compromisso } \\
\text { - Busca } \\
\text { - Contínua }\end{array}$ \\
\hline
\end{tabular}

Fonte: dados organizados pelas autoras com base no teste de associação livre de palavras.

As palavras sistematicidade, necessária, prática, compromisso, busca e contínua estão no sentido de caracterização da formação continuada, apontando elementos de acordo com os quais a formação é ou deveria ser. Como se disséssemos que a formação continuada precisasse ser ou fosse uma prática contínua, necessária, sistêmica, uma busca e um compromisso.

As justificativas dadas pelos formadores presentes no teste de associação nos ajudaram também na criação das duas categorias acima. Por exemplo, quando um formador se referiu à palavra contínua e a escolheu como principal, justificou que "continuidade dá a ideia de processo de formação" (F10) ${ }^{12}$, ressaltando, no nosso entender, uma característica que a formação tem ou precisaria ter.

Já as demais palavras remetem mais ao sentido do que a formação continuada proporciona ao indivíduo. Por exemplo: uma reflexão, uma troca de saberes, um aperfeiçoamento, uma capacitação, um estudo, etc. Destacamos uma fala: "A formação continuada é proposta de modo que os professores reflitam sobre o ensino e a aprendizagem, acompanhando os estudos e as pesquisas nas áreas do conhecimento" (F02). A afirmação do formador remete a um aspecto de contribuição da formação continuada para o sujeito, que, no caso citado, foi o de proporcionar um momento de reflexão.

Além das duas categorias criadas e mencionadas acima, algumas importantes observações precisam ser feitas.

A primeira refere-se às palavras/expressões mais associadas ao termo indutor formação continuada (reflexão e troca de saberes). Fizemos uma leitura da proposta de formação continuada do Centro e constatamos a relação entre ela e o discurso dos formadores. A proposta coloca que os formadores precisam

refletir sobre diferentes concepções de formação continuada com ênfase na abordagem crítico-reflexiva; refletir sobre os saberes docentes e o cotidiano da sala de aula; refletir sobre o papel das experiências pessoais e profissionais na construção da identidade profissional (FERREIRA, 2007, p.7).

Isto nos revela uma relação entre o que diz a proposta e os discursos dos formadores, mostrando assim uma influência institucional na representação de formação continuada compartilhada pelos formadores.

A segunda observação que fazemos refere-se às palavras mais associadas ao termo indutor formação continuada. Para Abric (1994), os elementos com maior frequência, juntamente com a escolha das duas palavras principais são o que supostamente compõe o sistema central de uma representação.

Então acreditamos que reflexão, troca de saberes, aperfeiçoamento e capacitação são parte do núcleo central na representação de formação continuada.

12 Utilizaremos a letra F para identificar o formador seguido de um número entre 1 e 20. 
Segundo Abric (1998), os elementos que compõem o núcleo central são determinados pela natureza do objeto que é representado, bem como pelas relações que os sujeitos mantêm com o objeto e pelo sistema de valores e regras sociais que regem o contexto no qual os sujeitos estão inseridos. 0 autor ainda afirma que o sistema central é o mais resistente às mudanças.

As demais palavras/expressões associadas aparecem, no nosso entender, como constituintes do sistema periférico que, segundo Abric (1998), está mais associado a características individuais e a contextos imediatos e contingentes de inserção dos indivíduos, a partir de suas experiências cotidianas, sendo um sistema mais flexível que o sistema central.

A terceira e última observação que fazemos em relação às associações ao termo indutor formação continuada refere-se às palavras aperfeiçoamento e capacitação, terceira e quarta palavras com maior frequência.

Ressaltamos que é necessário ter cuidado com a utilização de tais palavras, dado que elas podem ser reducionistas em relação a toda a complexidade que envolve a formação continuada.

Aguiar (2004) ressalta ainda que esses conceitos (aperfeiçoamento, capacitação, treinamento, reciclagem) dão a ideia de preparar os docentes para uma prática repetitiva, acrítica e mecânica.

\subsection{ANÁLISE DAS PALAVRAS PRINCIPAIS ASSOCIADAS AO TERMO INDUTOR FORMAÇÃO CONTINUADA}

Abric (1994) faz crítica ao uso apenas da frequência das palavras evocadas em detrimento da frequência da ordem de importância atribuída pelos sujeitos alegando que, em um discurso, as coisas essenciais não aparecem, frequentemente, senão após uma fase mais ou menos longa de aquecimento, ou seja, de estabelecimento de confiança ou de redução dos mecanismos de defesa.

A análise das palavras principais foi feita a partir das duas escolhas entre as cinco palavras/expressões que os formadores associaram ao termo formação continuada, bem como as justificativas dadas por eles.

\begin{tabular}{|c|}
\hline Termo indutor formação continuada \\
Reflexão (13) \\
\hline Troca de saberes (8) \\
\hline Aperfeiçoamento (5) \\
\hline Capacitação (5) \\
\hline
\end{tabular}

Fonte: dados organizados pelas autoras com base no teste de associação livre de palavras.

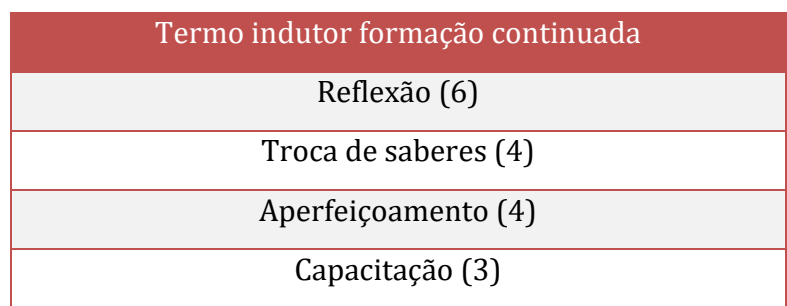

Fonte: dados organizados pelas autoras com base no teste de associação livre de palavras

Observando as tabelas, constatamos que as quatro palavras/expressões associadas com maior frequência ao termo indutor formação continuada (tabela 3) também foram as mesmas palavras/expressões que tiveram maior frequência no que se refere à escolha das palavras principais (tabela 4).

Observando também as justificativas dadas pelos formadores para as escolhas de tais palavras principais, percebemos um dado interessante.

"A formação continuada é um momento no qual o docente reflete sobre a sua prática" (F05). Justificativa dada à palavra reflexão. 
"A formação continuada deve ser um momento para parar e aperfeiçoar seus conhecimentos" (F06). Justificativa dada à palavra aperfeiçoamento.

As justificativas dadas pelos formadores às palavras principais nos dão pistas de que eles representam a formação continuada como um momento específico, entendido como curso, como formação continuada apenas no coletivo.

Ducoing (2007) aponta que a formação pode ser compreendida na distinção entre interioridade e exterioridade. A autora fala que se trata de dois olhares representativos opostos.

A exterioridade, a que se fazem muitas alusões, constitui uma posição reducionista para compreender a complexidade deste processo. [...] a formação [na perspectiva da exterioridade] é considerada como "qualquer coisa para" ou qualquer coisa "que se tem" ou "que se adquiriu". [...] quando nos referimos à formação, ela tende a ser relacionada com os conteúdos, e é compreendida como uma aquisição de conhecimentos, de habilidades, de atitudes e assume a conotação de um objeto que se pode obter e que pode ser comercializado (DUCOING, 2007, p. 329) [grifo nosso].

Diferentemente da visão da exterioridade, a interioridade visa à formação como um processo pelo qual o indivíduo se compromete a procurar e a tornar reais as suas possibilidades, bem como é por isso que qualquer ação formativa se desenvolve a partir do olhar e do agir sobre si mesmo (DUCOING, 2007).

Com base nas observações feitas acreditamos na possibilidade de estruturar os termos reflexão, troca de saberes, aperfeiçoamento e capacitação como fazendo parte de um núcleo central, mas ainda contamos com a entrevista semiestruturada, que ajudará a aprofundar a compreensão da representação social de formação continuada compartilhada pelos formadores do CEEL.

As categorias apresentadas a seguir surgiram da leitura e releitura do material coletado, em conformidade com a proposta de Bardin (2004) e as considerações de Arruda (2005).

\subsection{CONCEITUANDO A FORMAÇÃO CONTINUADA}

A primeira indagação da entrevista realizada com os formadores foi na intenção de que colocassem o que entendem por formação continuada. Ao contrário do teste de associação livre, que solicitava que escrevessem cinco palavras ou expressões que lhes viessem à mente ao lerem o termo formação continuada, nesse momento de entrevista os formadores poderiam argumentar mais, citar experiências, etc., bem como podíamos também interagir com os entrevistados, reformulando a pergunta ou solicitando que esclarecessem alguma questão em sua fala, por exemplo.

Com as respostas dos formadores à indagação feita, percebemos que eles colocaram duas formas distintas de como entendem a formação continuada. Assim, criamos duas subcategorias para dar conta de como a formação continuada é entendida pelo grupo.

Gráfico 1 - Compreensão da formação continuada

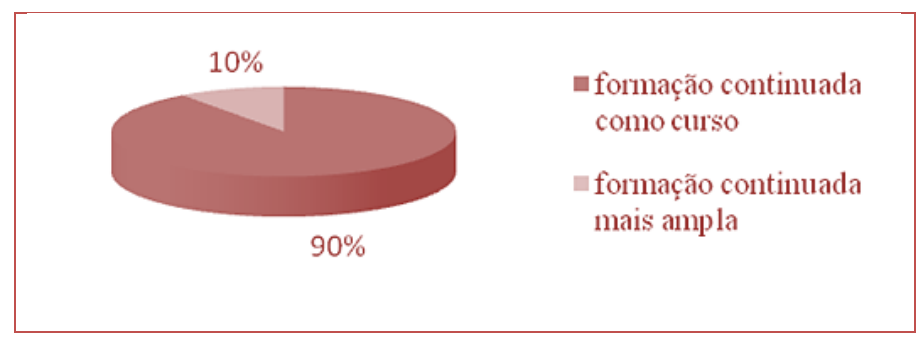

Fonte: dados organizados pelas autoras com base no teste de associação livre de palavras. 
Observando a subcategoria com maioria de $90 \%$, observamos que a formação continuada é vista como um curso, ou seja, como um momento específico de curso no coletivo.

"O que eu entendo por formação continuada é um momento em que o professor pára e reflete sobre suas práticas. Um momento em que ele pode estar trocando experiências e estar em contato com outros profissionais da área" (F20);

"Eu acho que são momentos em que o professor não só tem acesso a outras práticas, que ele reflete sobre suas práticas, que ele compara sua prática com outras práticas de outros professores, troca experiências" (F05).

Tais colocações feitas pelos formadores corroboram o que afirmamos anteriormente quando dissemos, na análise das palavras principais, que os formadores representam a formação continuada como apenas um curso e que isso se constitui numa posição reducionista da complexidade do processo de formação (DUCOING, 2007).

Acreditamos que, ao entenderem a formação continuada como um momento de curso, os formadores estão objetivando.

A objetivação é o processo que os indivíduos vão utilizar para tentar reduzir a distância entre o conhecimento do objeto social que eles constroem e a percepção que eles têm deste objeto. Ou seja, são vinculadas imagens concretas que, supostamente, vêm corroborá-las (DESCHAMPS; MOLINER, 2009, p. 127).

Em outras palavras, segundo Moscovici (2003), a objetivação "é transformar algo abstrato em algo quase concreto, transferir o que está na mente em algo que exista no mundo físico" (p.61).

Diferentemente, na outra subcategoria a formação continuada é entendida, de uma forma mais ampla, como algo que vai além de momentos de cursos e que abrange a dimensão coletiva e individual do processo formativo.

"Formação continuada é tudo o que se dá depois da formação inicial. Porque formação continuada nunca termina. Você pode ter, pela busca do próprio sujeito, mestrado, doutorado, etc., e você pode ter pelas políticas públicas" (F10).

Marcelo Garcia (1995), quando conceitua a formação de professores - seja ela inicial ou continuada -, ressalta a questão individual e a coletiva como importantes ao processo de formação. Nessa mesma direção, Almeida (2006) dá ênfase ao componente individual na formação, pois o entende como necessário ao indivíduo, porquanto cabem a ele a capacidade e a vontade de se formar.

\subsection{PRINCIPAIS ELEMENTOS DA FORMAÇÃO CONTINUADA}

0 segundo questionamento que fizemos aos formadores foi no intuito de compreender o que eles consideram importante na formação continuada. Nossa hipótese, baseada no teste de associação livre, seria que as palavras/expressões reflexão, troca de saberes, capacitação e aperfeiçoamento seriam levantadas pelos formadores no momento da entrevista, visto que, como vimos na análise do teste, foram palavras que tiveram maior frequência.

\begin{tabular}{|c|c|c|c|c|c|}
\hline & $\begin{array}{l}\text { Troca de } \\
\text { saberes }\end{array}$ & Reflexão & Aperfeiçoamento & Capacitação & Teoria \\
\hline $\begin{array}{ll}\text { Quantidade } & \text { de } \\
\text { formadores }^{13} & \end{array}$ & 7 & 5 & 3 & 3 & 2 \\
\hline
\end{tabular}

Fonte: dados organizados pelas autoras com base no teste de associação livre de palavras.

Em conformidade com o teste de associação livre, os termos troca de saberes, reflexão, aperfeiçoamento $e$ capacitação mais uma vez se fizeram presentes nas falas dos formadores. Esse fato aponta tais termos como constituintes de um núcleo central da representação social de formação continuada.

${ }^{13}$ A soma total de formadores é superior a dez, pois alguns destacaram mais de um elemento. 
"Eu acho que a formação é mais esse momento de reflexão e de troca de saberes" (F05).

“[...] para que o professor possa estar se capacitando através dos momentos de reflexão e troca de experiências" (F03);

"A troca de informações e a reflexão em cima da troca garantem o aperfeiçoamento" (F02).

Para Cordeiro (2008), é necessário induzir o professor a pensar sobre o que o leva a desenvolver esta ou aquela atividade, e isso se daria por meio da reflexão e da articulação dos diversos saberes. A troca de saberes também é bastante rica para o momento da formação continuada (NÓVOA, 1992). Já os termos capacitação e aperfeiçoamento levantados pelos formadores são reducionistas da formação continuada (RESENDE; FORTES, 2005; FREITAS, 2007; CHRISTOV, 2002).

No entanto, o que chamou a nossa atenção foi o fato de esses termos mencionados pelos formadores troca de saberes, reflexão, aperfeiçoamento e capacitação - estarem se relacionando um com o outro. Segundo Abric (1994), o núcleo central de uma representação apresenta como uma de suas funções a função organizadora, na qual o núcleo une os elementos da representação, dando assim estabilidade à mesma.

Observando as falas acima, constatamos que os formadores apontam uma relação existente entre as palavras que acreditamos fazerem parte do núcleo central da representação de formação continuada: a reflexão é feita a partir da troca de saberes, que por sua vez, é o caminho para a reflexão e os dois juntos reflexão e troca de saberes - capacitam/aperfeiçoam os professores. Notamos, assim, que os termos troca de saberes, reflexão, aperfeiçoamento e capacitação estão interligados e são interdependentes, organizando o núcleo central.

No que se refere ao termo teoria, destacado por dois formadores, duas considerações precisam ser feitas. Primeiro, concordamos com Nóvoa (1992) quando ele ressalta a importância do enfoque teórico para que a formação em coletivo não fique apenas no nível da troca de experiências.

"A teoria, que muitas vezes é deixada de lado [...]. Entendo que toda formação continuada precisa reunir aspectos teóricos para poder refletir sobre a prática, bem como os relatos de experiências também são importantíssimos" (F20).

"Um bom aporte teórico [...]. fazer esta relação teoria e prática" (F10).

As falas desses formadores nos mostram um avanço, ao pensarem a teoria como algo importante na formação continuada. Esse fato aponta para a necessidade de superação da distância que ainda existe entre a teoria e a prática.

A segunda consideração refere-se à teoria das representações sociais. Reafirmamos que, de acordo com Abric (1998), o sistema periférico de uma representação é mais flexível que o central e está mais ligado às características individuais. Notamos que os dois formadores que trouxeram o termo teoria nesse momento de entrevista foram os mesmos e únicos que o mencionaram durante o teste de associação livre (ver tabela 1). Por esse motivo acreditamos na possibilidade de esse termo constituir parte do sistema periférico da representação de formação continuada.

\subsection{ALGUMAS CONSIDERAÇõES}

Não se pode negar que os contextos sociais e educativos que condicionam todo ato social, e, assim sendo, a formação do professor, mudaram muito nos últimos anos (IMBERNÓN, 2009). Mediante as vertiginosas mudanças do mundo globalizado, procuramos entender como a formação continuada de professores vem sendo percebida por seus formadores, uma vez que entendemos a pessoa do formador como um agente essencial no processo de (re)significação, (re)configuração e (re)conceitualização da formação continuada, no contexto das representações sociais.

O desenvolvimento da pesquisa nos levou a compreender quais representações sociais de formação continuada são compartilhadas por seus formadores. As evidências apontadas pelos achados nos permitiram tecer algumas considerações a fim de responder, ainda que de forma provisória, às questões levantadas.

No percurso do trabalho, constamos que os formadores representam a formação continuada como um momento de curso. Alertamos para o cuidado com tal reducionismo, uma vez que a formação continuada se estende por toda a vida do profissional e este não está em processo de formação apenas mediante sua presença em um curso com um formador. 
A formação continuada aqui defendida compreende que o processo formativo se dá primeiramente pela vontade do profissional em formar-se, bem como não se limita a um momento formal de curso, mas abrange, por exemplo, participações em congressos, conferências, leituras, etc., pois todos esses podem levar o profissional a reflexões e aprendizado.

Constatamos também a existência de alguns pontos convergentes com o nosso entendimento de formação continuada, como a questão da reflexão e a da troca de saberes, apontadas no teste de associação livre e na entrevista, como elementos constituintes do processo de formação. Mas também percebemos pontos divergentes e que reduzem a complexidade da formação continuada, como a utilização das palavras capacitação, treinamento e aperfeiçoamento, mencionadas durante o teste e a entrevista.

\section{REFERÊNCIAS}

[1] ABRIC, Jean-Claude. Les représentations sociales: aspects théoriques. In: Abric Jean-Claude. Pratiques sociales et représentations. Paris: Presses Universitaires de France, 1994. p. 11-35.

[2] _... _. abordagem estrutural das representações sociais. In: Moreira, Antonia Silvia Paredes; Oliveira, Denize Cristina de. (Orgs.). Estudos interdisciplinares de representação social. Goiânia: A B editora, 1998. p. 27-38.

[3] AGUIAR, Maria da Conceição Carrilho de. A formação contínua do docente como elemento na construção de sua identidade. Tese (Doutorado em Ciências da Educação). Faculdade de Psicologia e Ciências da Educação da Universidade do Porto. Portugal, 2004

[4] ALMEIDA, Angela Maria de Oliveira. A pesquisa em representações sociais: proposições teóricometodológicas In: SANTOS, Maria de Fátima de Souza e ALMEIDA, Leda Maria de. Diálogos com a teoria das representações sociais. Recife: Ed. Universitária UFPE, 2005.

[5] ALMEIDA, Maria Isabel de. Apontamentos a respeito da formação de professores In: BARBOSA, Raquel Lazzari Leite (Org.). Formação de educadores: artes e técnicas, ciências e políticas. São Paulo: Editora UNESP, 2006. p. 177-188.

[6] ARRUDA, Angela. Despertando do pesadelo: a interpretação. In: MOREIRA, Antonia Silvia Paredes; CAMARGO, B. V.; JESUÍNO, Jorge Correia; NÓBREGA, S. M. (Orgs.). Perspectivas teórico-metodológicas em representações sociais. João Pessoa: Editora Universitária, 2005. p. 229-258.

[7] BARDIN, Laurence. Análise de conteúdo. Lisboa-Portugal: Edições 70, 2004.

[8] CHRISTOV, Luiza Helena da Silva. Educação continuada: função essencial do coordenador pedagógico!. In: GUIMARÃES, Ana Archangelo. et all. 0 coordenador pedagógico e a educação continuada. 5ํedição. Ed. Loyola. São Paulo, 2002. p. 72-84.

[9] CORDEIRO, Telma Santa Clara. A formação pedagógico-profissional do professor universitário segundo a voz do próprio professor: subsídios para um programa de formação continuada na UFPE. In: CORDEIRO, Telma Santa Clara MELO, Márcia. M. Oliveira. (Orgs.). Formação pedagógica do professor Universitário. Recife: Editora Universitária UFPE, 2008. p. 105-128.

[10] DESCHAMPS, Jean-Claude; MOLINER, Pascal. A identidade em psicologia social: dos processos identitários às representações sociais. Petrópolis: Vozes, 2009.

[11] DUCOING, Patrícia. A formação de professores e de profissionais da educação: sobre as noções de formação. In: ESTRELA, Albano. (Org.). Investigação em educação: teorias e práticas (1960-2005). Lisboa: Educa, 2007. p. 321336.

[12] FERREIRA, Andrea. Tereza. Brito. Formação continuada de professores: questões para a reflexão. Recife: Autêntica, 2007.

[13] FRANCO, Maria Laura Puglisi Barbosa. Análise de conteúdo. Brasilia: Liber Livro Editora, 2008.

[14] FREITAS, Alexandre Simão de. Os desafios da formação de professores no século XXI: competências e solidariedade. In: FERREIRA, Andrea Tereza Brito; ALBUQUERQUE, Eliana Borges Correia de; LEAL, Telma Ferraz. (Orgs.). Formação continuada de professores: questões para reflexão. Belo Horizonte: Autêntica, 2007. p. 11-32.

[15] IMBERNÓN, Francisco. Formação permanente do professorado: novas tendências. São Paulo: Cortez, 2009.

[16] MARCELO GARCIA, Carlos. Formación del professorado para el cambio educativo. Barcelona: UEB, 1995.

[17] MOSCOVICI, Serge. A representação social da psicanálise. Tradução de Álvaro Cabral. Rio de Janeiro: Zahar Editores, 1978. 
[19] NÓVOA, Antonio. Formação de professores e profissão docente, In: NÓVOA, Antonio.(Org.). Os professores e sua formação. Lisboa: Publicações Dom Quixote. Instituto de Inovação Educacional, 1992. p. 15-33.

[20] PLACCO, Vera Maria Nigro de Souza; SILVA, Sylvia Helena Sousa da. A formação do professor: reflexões, desafios, perspectiva. In: BRUNO, Eliane. Bambini. Gorgueira; ALMEIDA, Laurinha. Ramalho; CHRISTOV, Luiza Helen da Silva. $O$ coordenador pedagógico e a formação docente. São Paulo: Edições Loyola, 2002. p. 25-32.

[21] RESENDE, Lúcia Maria Gonçalves de. FORTES, Rodolfo Medeiros Cunha. Mudanças e inovações pedagógicas na formação continuada docente. In: ANPEd. 40 anos de pós-graduação em educação no Brasil: mudanças e inovações pedagógicas na formação continuada dos docentes. caxambu: 2005. p.1-16.

[22] SÁ, Celso Pereira de. A construção do objeto de pesquisa em representações sociais. Rio de Janeiro: EdUERJ, 1998. 


\section{Capítulo 21}

Formação continuada recursos tecnológicos e a organização do trabalho docente com sequências didáticas: Percepções dos professores cursistas

\section{Leida Gilvane Cantalice Ribeiro \\ Milene Mírian Araújo Monteiro \\ Josiano Regis Caria \\ Ieda Lucia de Oliveira Santana \\ Izabel Silva Bragança Pinheiro \\ Aldemira de Araújo Câmara}

Resumo: Este artigo propõe-se a problematizar o tema da formação continuada de professores a partir de uma experiência oriunda de um curso modular na rede Municipal da Cidade Manaus e tem como objetivo avaliar o curso de formação continuada Recursos Tecnológicos e a Organização do Trabalho Docente com Sequências Didáticas na visão de quatro professores do ciclo de alfabetização. A pesquisa foi realizada numa abordagem qualitativa com uma coleta de dados onde se focou na opinião das professoras cursistas. Na coleta de dados foram aplicados formulário com questões abertas e fechadas visando entender o fenômeno. Na fundamentação teórica apoiamo-nos na obra de Campos (2010), Alonso (1994) e Perrenoud (2002) que defendem a formação continuada de professores com um ato inacabado; Paviane (2009) e Pereira (2001) que abordam o trabalho com oficinas e um novo olhar para a expressão ajuda na profissão docente; Nóvoa (1992); Tardirf (2012); Candau (1997) que diz que o trabalho com oficinas é uma superação ao modelo clássico de se fazer formação continuada de professores e nos alerta também para a ida à escola sem objetivos; Alonso (1994) que vê o professor como sujeito em constante formação; Leal (2005); Cook-Gumperz (1991); Libâneo (1990); Dolz, Noverraz e Schneuwly (2004); Prensky (2001); Oliveira (2009); Silva (2012) e Lego Education (2003) que compreendem uma organização do fazer docente alicerçado no planejamento e articulado às Tecnologias de informação e Comunicação (TIC) como ferramenta motivadora no processo ensino e aprendizagem. Acredita-se que o curso de formação continuada para professores a partir de sequências didáticas seja um bom começo para a organização do trabalho pedagógico em sala de aula e consequentemente um dos caminhos para uma educação de qualidade.

Palavras-chave: Recursos tecnológicos. Trabalho pedagógico. Oficina em Serviço. 


\section{INTRODUÇÃO}

Nos últimos tempos, a formação continuada de professores tem sido uma das reocupações tanto para o poder público, como para pesquisadores que buscam explicações e soluções para os desafios e novas provocações no campo educacional. "O professor deve ser formado em sua formação para ensinar. A sua formação deve contemplar a construção de uma nova mentalidade de ensino". (CAMPOS, p. 137, 2010).

Um dos grandes desafios para a Divisão de Desenvolvimento do Profissional do magistério (DDPM) e Gerência de Tecnologia Educacional (GTE) é elaborar modelo de formação a ser aplicada ao pouco tempo disponibilizado aos encontros presenciais com professores, rompendo ao mesmo tempo com os modelos vigentes, que desconsideram ou minimizam a relevância do contexto escolar, e que nem sempre atendem as reais necessidades dos professores em sala de aula. Diante disto, buscou-se elaborar uma proposta de formação continuada de professores, que seja construída e acompanhada durante o período de curso, considerando como fundamentais e constituintes a cultura escolar, a subjetividade, as temáticas abordadas pela escola, os projetos, e mais importante, o professor e os demais envolvidos no processo. Mas como proceder com o pouco tempo disponibilizado para encontros presenciais? Diante da necessidade de mais tempo de para abordar os conceitos teóricos importantes, a solução encontrada para foi dispor os materiais necessários a pesquisa dos professores em uma sala virtual. Elaborando assim, a proposta de curso com momentos presenciais e a distância através da plataforma MOODLE, com módulos que contemplem conceitos teóricos e atividades práticas para aplicar em sala de aula. 0 curso intitulou-se Recursos Tecnológicos e a Organização do Trabalho Pedagógico com Sequências Didáticas, com isso surge também a problemática do estudo que vem indagar quais as percepções dos professores cursistas com relação ao referido curso. Nessa direção, este artigo tem como objetivo avaliar as percepções dos professores cursistas relacionadas ao referido curso.

A pesquisa foi realizada por uma abordagem qualitativa tendo como objeto de estudo, uma escola pública municipal localizada na zona oeste de Manaus. Como instrumentos de coletas de dados foram utilizados formulários que abordavam questões fechadas, as quais deviam ser atribuídas um conceito regular, bom ou ótimo. No final uma questão aberta onde os pesquisados optaram em dar sugestões ou não sobre as atividades desenvolvidas.

Na fundamentação teórica apoiamo-nos na obra de Campos (2010), Alonso (1994) e Perrenoud (2002) que defendem a formação continuada de professores com um ato inacabado; Paviane (2009) e Pereira (2001) que abordam o trabalho com oficinas e um novo olhar para a expressão ajuda na profissão docente; Nóvoa (1992); Tardirf (2012); Candau (1997) que diz que o trabalho com oficinas é uma superação ao modelo clássico de se fazer formação continuada de professores e nos alerta também para a ida à escola sem objetivos; Alonso (1994) que vê o professor como sujeito em constante formação; Leal (2005); Cook-Gumperz (1991); Libâneo (1990); Dolz, Noverraz e Schneuwly (2004); Prensky (2001); Oliveira (2009); Silva (2012) e Lego Education (2003) que compreendem uma organização do fazer docente alicerçado no planejamento e articulado às Tecnologias de informação e Comunicação (TIC) como ferramenta motivadora no processo ensino e aprendizagem.

Diante deste contexto, acredita-se que o referido estudo irá contribuir para repensarmos a formação continuada de professores num propósito mais real e próximo das necessidades e anseios dos docentes. 0 trabalho que já vem sendo realizado na rede municipal de ensino na cidade de Manaus, como mostra a pesquisa, demonstra as contribuições desta prática como uma das formas de ir até à escola e propor uma ação reflexiva ligada aos objetivos de ensino previamente planejado pelo professor.

\section{REFLETINDO SOBRE 0 TEMA}

A formação continuada do professor é uma das soluções para o enfretamento de novas provocações no contexto escolar, que não promete resolver todas as mazelas educacionais, mas que permanece sendo uma das ações mais coesas e precisas a serem desenvolvidas e valorizadas pelo poder público e até mesmo pelo próprio docente.

Falar de docência é falar de formação, afinal docência é atividades essencialmente formadora e auto formadora. A essência do trabalho docente está no investimento da própria formação e na formação de quem o cerca, em especial o aluno. "Esse profissional terá que ser visto como alguém que não está pronto, acabado, mas em constante formação" (ALONSO, 1994, p.61).

Para o autor o professor é um transformador da realidade, vive em eternas busca por respostas para um novo problema. Resumir o papel do docente em mero executor de tarefas vem por em declínio sua 
autonomia profissional. As repostas para os problemas em sala de aula devem ser buscadas coletivamente com base principalmente na experiência acumulada deste profissional a qual não advém somente do período que esteve em formação na graduação. Sobre o assunto Perrenoud (2002, p. 50) afirma que:

[...] seria absurdo esperar que uma formação inicial, por mais completa que fosse, pudesse antecipar todas as situações que um professor encontraria em algum momento do exercício de sua profissão e oferecerlhe todos os conhecimentos e as competências que, algum dia, poderiam ser úteis a ele.

A busca por uma solução coletiva para os problemas no contexto escolar pode estar numa prática de formação continuada dentro de uma proposta metodológica de oficinas pedagógica. Esta é uma ação que beneficia a construção e reconstrução de saberes, a discussão e reflexão crítica em torno de experiências adquiridas. Para definir tal termo destacamos:

\begin{abstract}
Uma oficina é, pois, uma oportunidade de vivenciar situações concretas e significativas, baseada no tripé: sentir-pensar-agir, com objetivos pedagógicos. Nesse sentido, a metodologia da oficina muda o foco tradicional da aprendizagem (cognição), passando a incorporar a ação e a reflexão. Em outras palavras, numa oficina ocorrem apropriação, construção e produção de conhecimentos teóricos e práticos, de forma ativa e reflexiva (PAVIANI, 2009, p. 78).
\end{abstract}

Este modelo de formação se contradiz a forma tradicional e opressora que ainda se conduz a educação, às atuações descontextualizadas da história do docente, em uma relação vertical de dominados e dominantes. Assim, ao se propor uma formação continuada a partir de oficinas pedagógicas sejam elas desenvolvidas na própria sala de aula com alunos ou apenas com o professor, não se descarta os diferentes saberes construídos ao longo de anos. A proposta não é de ensinar fórmulas mágicas para a resolução de problemas da escola, o objetivo centra-se principalmente na provocação desse profissional a refletir sobre a prática e assim visualizar possibilidades para a realidade em que estão inseridos.

0 contato com o mundo real de sala de aula e com as pessoas que nela atuam nos remete à ideia de ajuda profissional. Não se trata de se propor momentos de autoajuda nem terapia para julgar o próprio fazer ou dos outros. Busca-se ajudar o profissional permitindo-o vivenciar situações dentro do próprio ambiente de trabalho. Assim, serão capazes de observar, sentir, julgar, concluir e comparar as ações que estão sendo desenvolvidas no momento com as que já praticam em sala de aula. De acordo com Pereira (2001, p. 43):

Ajudar é dar condições para que a pessoa se conscientize da própria experiência, de suas ações e reações, de suas fantasias, permitindo que se descubra por si mesma. Todos têm algum potencial que ainda não está em uso, muitos são bem mais capazes, inteligentes, fortes, criativos e hábeis do que acreditam ser.

Corroboramos com a ideia de Pereira (2001) de que o trabalho com oficinas não se reduz apenas num momento de contato para diálogos infundados sem sentido. A capacidade dos envolvidos é estimulada a partir do momento que os conteúdos a serem abordados nos encontros estejam realmente voltados para a solução de problemas advindos do dia a dia em sala de aula.

\title{
3 OFICINAS PEDAGÓGICAS E A VALORIZAÇÃO DO SABER DOCENTE: UMA RELAÇÃO ENTRE TEORIA E PRÁTICA
}

A descoberta e a valorização de novos saberes, em especial o saber docente é extremamente importante no trabalho com oficinas pedagógicas. Considera a formação como um processo mútuo, onde os educadores são estimulados a externar seus conhecimentos dividindo-os com terceiros em prol de um consenso significativo. A relação formando e formador é favorecida pelo ato da troca, pois ao mesmo tempo em que eu aprendo ensino e vice-versa.

Assim, cabe também ao professor expor seus saberes e contribuir com a própria formação, como defende Nóvoa (1992, p. 25-26) "a troca de experiências e a partilha de saberes consolidam espaços de formação mútua, nos quais cada professor é chamado a desempenhar, simultaneamente, o papel de formador e de formando". 
O saber docente não se delimita em apenas repassar o que lhe foi ensinado. A partir da sua relação com outros conhecimentos se constrói uma cadeia de saberes. As experiências no chão da escola também se transformam em saberes vindo não somente de uma formação inicial das universidades e dos currículos. A prática docente, em meio às inúmeras ações desenvolvidas em sala de aula se transforma em saberes experienciais, essencialmente heterogêneos influenciados, mesmo que de forma confusa, pela formação profissional adquirida ao longo do exercício da profissão. "Pode-se definir o saber docente como um saber plural, formado pelo amálgama, mais ou menos coerente, de saberes oriundos da formação profissional e de saberes disciplinares, curriculares e experienciais" (TARDIF, 2012, p. 36).

Os saberes experienciais surgem como essência do saber docente, a partir da qual os professores tentam transformar seus aprendizados que recebem de suas relações de exterioridade integrando-os à sua prática já existente. 0 mesmo autor, conclui seu pensamento afirmando que:

Essas relações exteriores inserem-se, hoje, numa divisão social do trabalho intelectual entre os produtores de saberes e os formadores, entre os grupos e instituições responsáveis pelas nobres tarefas de produção e legitimação dos saberes e os grupos e instituiçõos responsáveis pelas tarefas de formação, concebidas nos moldes desvalorizados da execução, da aplicação de técnicas pedagógicas, do saber-fazer (op. cit, p.54).

É comum a persistência da dissociação entre a formação e prática cotidiana, não enfatizando a questão dos saberes que são mobilizados no exercício da função, ou seja, os saberes das experiências. A identidade do professor passa a ser integrada por essas vivencias. Essa diversidade de conhecimentos é oriunda do dia a dia e do meio.

Pode-se afirmar que o conhecimento é um processo contínuo de construção, de tal maneira que é necessário um novo repensar na formação continuada. Uma forma de se pensar no procedimento seria a formação em lócus. Esta é considerada por Candau (1997) como a superação de um modelo clássico e a construção de uma nova perspectiva na área em questão. Mas, a autora alerta que para se alcançar os reais objetivos não é satisfatório apenas ir à escola e propor uma atividade escolar concreta e repetitiva que mobilize os envolvidos. Isso significa mecanizar o processo formativo, os sujeitos certamente não valorizarão o momento. Para que a prática se torne reflexiva deverão estar ligadas à resolução de problemas, ou seja, não somente detectá-los, mas propor solução coletiva. Assim todos os saberes e conhecimentos serão valorizados e a escola como espaço de interação de sujeitos será bem mais organizada na solidificação de seu verdadeiro papel.

\section{A ORGANIZAÇÃO DO TRABALHO PEDAGÓGICO E OS NOVOS DESAFIOS}

A educação escolar foi sendo estabelecida ao longo dos tempos a partir das transformações vividas na sociedade. Cada era formou modelos de práticas escolares que marcaram o momento mesmo que de forma significativa ou não.

Toda escola tem sua cultura própria e formas diversificadas ou comuns de se organizar. Pimenta (1988) adverte que de fato tal organização envolve o trabalho coletivo dos sujeitos que compõem este espaço. Para a compreensão dessa natureza de trabalho constata-se que tudo gira em torno de uma prática social coletiva de vários profissionais que desenvolvem distintos papéis e possuem diferentes especialidades. Desde já, a organização da escola compete aos profissionais docentes e não docentes. Seria ingênuo advogar ao professor o dever de suprir todas as funções que extrapolam a sala de aula, mas que interferem na ação deste profissional. Todavia, suas escolhas e atitudes contribuem significativamente para a qualidade do trabalho pedagógico e melhoria do ensino.

Os vários caráteres de se desenvolver o processo de ensino e aprendizagem adentram na instituição escolar por meio do fazer docente. Os caminhos são inúmeros e demandam planejamento juntamente com tomada de decisões. Cada professor está habituado a percorrer diferentes rumos na jornada diária de sala de aula. As escolhas não devem apenas levar em conta a experiência profissional, mas também os conhecimentos acumulados dos envolvidos no processo.

No contexto atual, podemos perceber mudanças expressivas nas práticas cotidianas escolares à proporção que surgem novas possibilidades. Algumas atividades foram esquecidas ou supridas por outras motivadas pelo surgimento de novas visões embasadas em pesquisas ou das necessidades de dar conta das transformações ocorridas na sociedade, em especial as advindas do avanço tecnológico. Um exemplo 
expressivo é quando nos reportamos ao ensino da linguagem oral e escrita. Segundo Ferreira (2012, p. 15):

Podemos perceber algumas mudanças e permanências. Da rotina que envolvia as repetições incansáveis do recitar dos textos sagrados às que priorizavam o ensino de gramática como regras a ser apenas memorizada ou a leitura e produção de textos diversos, prática de ensino da língua materna fora sendo construídas. No caso específico da alfabetização, vários conceitos e metodologias influenciaram o desenvolvimento de diferentes práticas.

O currículo e as novas descobertas apontam para um ensino mais reflexivo e de efeito mútuo e autônomo. 0 sujeito que ensina aprende e o que aprende também ensina num movimento de reciprocidade. Assim como defende Cook-Gumperz (1991), o aprendizado da língua foi transformado pelo processo de escolarização em uma habilidade técnica, universal e padronizada. A leitura e escrita adentram nas necessidades individuais e coletivas, sendo necessária sua aproximação com as práticas sociais.

Diante desta realidade, vem se gerando novas organizações do fazer cotidiano das escolas e das salas de aula. A rotina tende a ser mais organizada e focada no que realmente é necessário para que a aprendizagem se torne significativa. Para isso, o planejamento escolar torna-se crucial, pois, "é um meio para se programar as ações docentes, mas é também um momento de pesquisa e reflexão intimamente ligado à avaliação" (LIBÂNEO, 1990, p. 161). A falta de planejamento pode gerar atividades circulares, que podem impossibilitar a real participação do alunado e reprimir seu crescimento intelectual.

Diante disso, é imprescindível que haja a garantia de um planejamento em qualquer situação ou modalidade de ensino institucionalizado a fim de organizar o tempo pedagógico. Para Leal (2005), o momento permite tomada de decisões, reflexão sobre a realidade do aluno e suas dificuldades. 0 processo se torna um ato sistematizado e alicerçado em reais objetivos, dando melhor condução às aulas, beneficiando também que o educador não só avalie os resultados, mas a própria postura.

Desse modo, a construção de uma rotina sistematizada a partir de um planejamento torna-se crucial para a organização dos momentos na escola. Por tanto, "o estabelecimento de uma sequência básica de atividades diárias, a "rotina", é útil para orientar a criança e perceber a relação espaço-tempo, podendo aos poucos prever o funcionamento dos horários" (OLIVEIRA, 1992, p. 76). Essa atitude não se reduz somente a pratica do professor, mas também ao relacionamento dos sujeitos em sala de aula. Um ambiente de estabilidade e segurança tem sua devida importância no processo educacional.

Os modos de organização são diversos, sobre o assunto Leal adverte que "ao tratar sobre planejamento didático, cito cinco formas de organização das atividades, entre outras possíveis; atividades permanentes, projetos didáticos, atividades sequenciais, atividades esporádicas e jogos" (2005 op. cit. p. 77).

Fica evidente que se deve opinar por uma ou outra estrutura, porém cada uma delas exige reflexão e buscas constantes por meio da pesquisa.

Entre os modelos de organização da rotina escolares anteriormente expostos, nos ateremos nas atividades sequenciais que é a articulação de diferentes momentos em torno de um mesmo assunto ou conteúdo. Como afirmam Dolz, Noverraz e Schneuwly (2004, p. 82) sequência didática é um "conjunto de atividades escolares organizadas, de maneira sistemática, em torno de um gênero textual oral ou escrito". A prática envolve metodologias e práticas que aperfeiçoam o ato da escrita dando autonomia ao aluno de se expressar de forma coerente e coesiva. No mesmo propósito Zabala (1998, p.18) explica que as sequências didáticas são "um conjunto de atividades ordenadas, estruturadas e articuladas para a realização de certos objetivos educacionais (...)". Portanto, possibilitam pensar o trabalho pedagógico de modo articulado, sistemático e contextualizado com vistas ao desenvolvimento das capacidades previstas nos direitos de aprendizagem.

As possibilidades de articulação nessa forma de se fazer educação escolar leva em conta duas características essenciais da atualidade quanto ao progresso tecnológico e à globalização da economia, é importante que se agregue às práticas de sala de aula, desde a formação básica, o uso de novas Tecnologias da Comunicação e Informação (TIC). Ao se reportar às TIC não falamos apenas de computadores, mas também dos diferentes equipamentos como data show, microssystem, lunetas, microscópio, caixa de som, etc. que favorecem a comunicação, a leitura e a produção de novos conhecimentos, textos, livros, painéis, etc. (OLIVEIRA, 2009). 
É evidente que quando agregados ao planejamento didático os recursos midiáticos passam a ter uma contribuição expressiva no desenvolvimento intelectual do educando. Mas para isso os docentes precisam se apropriar criticamente dessas ferramentas assumindo seu papel de imigrantes digitais em total relação com os nativos digitais (PRENSKY, 2001). As crianças já nascem inseridas no mundo tecnológico, portanto, é natural que estejam conectados à era dos computadores, dos celulares, da internet, dos games e outros. Essa nova geração exige um olhar diferenciado principalmente por parte do professor que deve buscar situações de ensino e aprendizagem capazes de motiva-los, pois as TIC podem oportunizar práticas de leitura e escrita não apenas através de um trabalho impresso, mas também em diferentes suportes tecnológicos de interação.

Entre os inúmeros atrativos tecnológicos é viável destacar o projeto de iniciação tecnológica lego educacional que traz uma proposta metodológica para a formação do aluno de forma integral, desenvolvendo as competências e habilidades necessárias para a atuação profissional e convívio na sociedade.

Os momentos em sala de aula são atrativos e lúdicos por envolver estratégias como trabalho em equipe, exposição oral, montagem de blocos coloridos com apoio de revistas, de forma direcionada de acordo com uma temática ou conteúdo antes planejada pelo professor. De acordo com Guimarães, Mota e Oliveira (2003, p. 3) a

[...] Metodologia LEGO ZOOM possibilita o desenvolvimento da criatividade, das relações entre as pessoas, do trabalho em equipe, da ética e da cidadania, permitindo ao professor praticar ações que desenvolvam nos alunos motivação, memória, linguagem, atenção, percepção, emoção,... Essa metodologia inovadora contempla quatro fases: Contextualizar, Construir, Analisar e Continuar.

Neste enfoque a ação pedagógica é pautada numa estrutura onde os conteúdos curriculares são abordados de forma interdisciplinar e que o aluno faz parte de um projeto, construindo o seu conhecimento por meio do trabalho em equipe, respeitando regras, interagindo com seus colegas e professor, sendo este o mediador do conhecimento.

O fato é que, articulada com a uma sequência didática, o uso dessas tecnologias pode aproximar alunos e professores, além de ser útil na exploração dos conteúdos de forma mais interativa. 0 discente passa de mero receptor, que só observa e nem sempre compreende, para um sujeito mais ativo e participativo.

\section{A PESQUISA NA ESCOLA}

O presente estudo está ajustado no âmbito de uma abordagem qualitativa pautada na fenomenologia como corrente de pensamento por apresentar complexidade e possibilitar a análise da realidade e reflexão a partir da interpretação do fenômeno assim como das práticas e atitudes dos participantes. Assim, realizou-se uma pesquisa descritiva já que envolveu como métodos procedimentais a observação, registro, análise, classificação e interpretação dos fatos coletados, precisamente sem a interferência da pessoa das pesquisadoras.

O estudo foi realizado na cidade de Manaus com 4 professoras da Educação Básica dos primeiros anos do ciclo de alfabetização de uma Escola Pública localizada na zona oeste do município.

A coleta de dados foi norteada por aplicação de questionário objetivando colher opiniões voltada á problemática do estudo, abordando questões abertas e fechadas.

Para o início das ações foi levado ao conhecimento da gestora da escola pesquisada um curso de formação continuada intitulado "Recursos Tecnológicos e a Organização do Trabalho Docente com Sequências Didáticas". 0 mesmo tinha como objetivo a compreensão sobre a organização do fazer pedagógico por meio de sequências didáticas articuladas às TIC e ás diversas áreas do conhecimento. A modalidade enquadrou-se na educação á distância, com uma carga horária de quarenta horas divididas em momentos presenciais e online pelo ambiente Virtual de Aprendizagem Moodle.

A seleção dos cursistas ficou a critério da gestão que optou pela a participação de quatro professoras dos primeiros anos do ciclo de alfabetização. Entre as justificativas seria a inexperiência na área educacional, pois duas das participantes haviam saído concluído a pouco tempo a graduação. É indiscutível que é comum tal fenômeno, a formação inicial não dá subsídios suficientes para uma formação completa com 
respostas prontas para todos os problemas existentes na sala de aula, mesmo porque o processo de formação tende a ser contínuo (PERRENOUD, 2002).

Os encontros aconteceram na própria escola ora somente com os professores, ora com professores e alunos em sala de aula no formato de oficinas em serviço (CANDAU,1997). As participantes eram orientadas e motivadas a construir a própria prática a partir da proposta curricular da Secretaria de Educação do Município e realidade da turma. Baseando-se no planejamento pré-elaborado pelas educadoras as sequências didáticas iam sendo elaboradas de forma articulada em diferentes temáticas (ZABALA, 1998). Entre as temáticas trabalhadas destacam-se: Do Campo a Mesa, Natureza Transformada, Nosso Povo! Nossa Gente e Direitos e Deveres. As sequências didáticas foram desenvolvidas por turma com aproximadamente cento e vinte alunos no total.

No decorrer das atividades as cursistas recebiam o assessoramento das formadoras com intuito de desenvolver ora com alunos e ora sem alunos momentos didáticos de leitura, escrita produção textual e orientações quanto à inserção e manuseio dos recursos disponíveis na escola de forma crítica e com sentido para o momento didático (PRENSKY, 2001). Oportunizava-se com isto, a construção de novos saberes, professores, formadores e alunos vivenciavam momentos de troca onde cada um dava suas contribuições num processo mútuo (NÓVOA, 1992).

\section{RESULTADOS}

O curso Recursos Tecnológicos e a Organização do Trabalho Docente por Sequências Didáticas foram uma experiência diferenciada dentro de uma sugestão de formação continuada de professores. A proposta ia além de um repasse de experiências ou artefatos teóricos ou tecnológicos. Os discentes e docentes vivenciaram momentos de troca, onde todos os envolvidos foram oportunizados a expor seus saberes em prol de um saber coletivo. As situações favoráveis de aprendizagem envolveram estratégias de leitura, relatos de experiências, trabalho em equipe que promoveram momentos ricos de partilha, a autorreflexão por parte do professor ao direcionar um olhar diferenciado dentro do próprio planejamento.

Ao se tomar como parâmetro a visão das professoras cursistas, as mesmas se posicionaram diante das indagações seguintes:

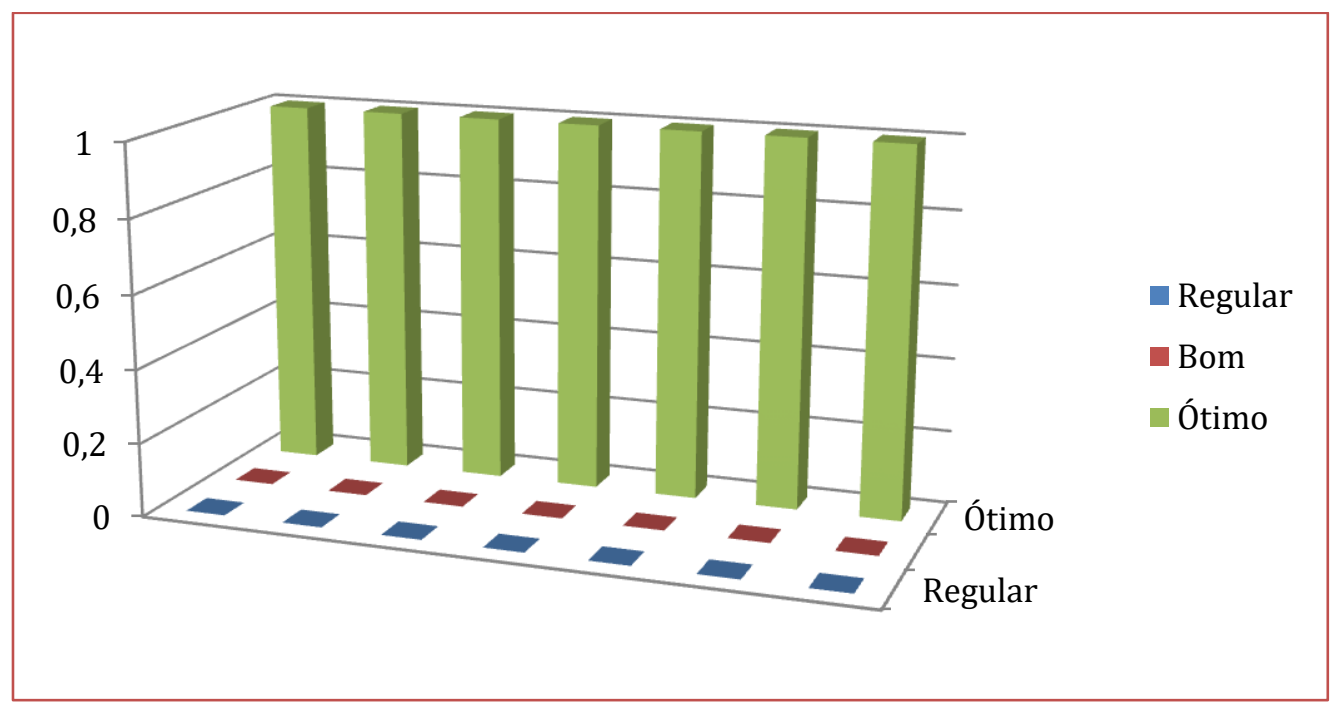

Os dados acima fazem referência à estrutura organizacional do curso nos seus diversos aspectos. Quanto ao material pedagógico fornecido pelos formadores, estes eram precisamente os que foram usados como apoio ao desenvolvimento das atividades juntamente com os recursos tecnológicos como data show, caixa de som, kit lego educacional e outros. Para as docentes os mesmos obtiveram o conceito ótimo com relação à sua disponibilidade. De acordo com a professora identificada por P1: 
As atividades propostas foram realizadas com recursos tecnológicos como: vídeos, data show, lego, computador entre outros. Com a utilização desses recursos foi possível observar uma melhor concentração e participação dos alunos nas atividades em sala, onde foi trabalhadas leitura e contextualização de textos, pesquisas, produção textual, leitura de imagens e trabalhos em equipe.

A educadora desenvolveu diversas atividades a partir do uso dos recursos disponibilizadas os quais contribuíram para uma melhor concentração dos alunos durante as aulas.

Para a professora identificada como P2:

A reorganização em desenvolver as atividades já conhecidas e ate então, revisadas para uso com um recurso do tipo lego, vídeo, computador entre outros. Com a utilização desses recursos levou a uma melhoria na leitura dos alunos através da contextualização, no uso de uma boa comunicação e bom dialogo por meio da pesquisa, produção de texto nos diversos gêneros textuais contos, poemas, textos descritivos e alguns críticos e através da dramatização conseguiram demonstrar a clareza em seu entendimento.

Percebe-se que os recursos e conteúdos utilizados durante o curso contribuíram satisfatoriamente nas práticas educativas em sala de aula das referidas professoras. As atividades passaram a ter mais significado por estarem contextualizadas e agregadas à ferramentas atrativas.

Os conteúdos das unidades foram dispostos em módulos para leitura das cursistas no AVA (ambiente virtual de aprendizagem). Com uma senha pessoal eram possibilitadas a navegar pela biblioteca e acessar outros artigos e sequencias didáticas direcionadas para a organização do trabalho em sala de aula. Assim as atividades para cada módulo iam se configurando, de forma ordenada seguindo parâmetros voltados para avaliação e aquisição de uma certificação no final do curso. Esta forma de interação possibilitou também o diálogo entre formadoras e cursistas que conceituaram como ótimo os pontos citados.

Foram realizados também assessoramentos pedagógicos durante o período do curso. Nesse contexto, as professoras recebiam visitas semanais das formadoras, pois, foram estes momentos que exigiram compreensão da direção da escola pelo fato de dar abertura para que os encontros e orientações acontecessem no período de aula. Na visão das professoras tais momentos foram considerados ótimos.

Quanto à funcionalidade do curso foram destacadas três questões de acordo como o gráfico abaixo:

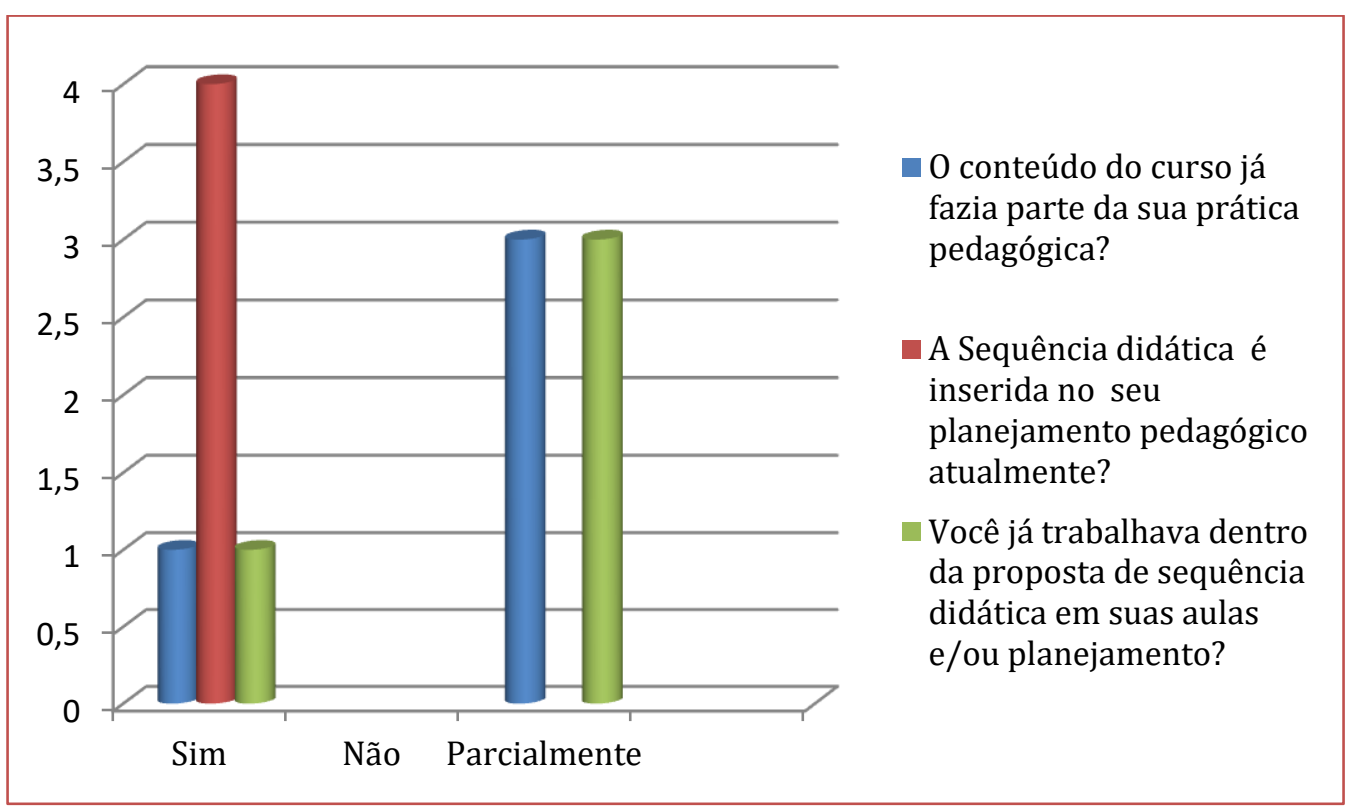


Quando indagadas se o conteúdo do curso já fazia parte de suas práticas pedagógicas três professoras expressaram ter parcialmente contato, enquanto uma disse já ter contato com os assuntos em seu fazer pedagógico.

As docentes declaram usar atualmente a sequência didática no dia a dia em sala de aula, pois, quando investigadas se usavam essa prática antes do curso três declaram que não e uma que sim. "A sequência didática trabalhada em minhas aulas foi elaborada a partir do planejamento mensal, facilitando a aplicação da mesma, de forma progressiva e interdisciplinar no cotidiano escolar" (P1). Isso significa que o planejamento era reorganizado de forma articulada com objetivos traçados no decorrer das atividades.

Para a cursista (P3) é recomendável que a "escola tivesse uma equipe de apoio para planejar, procurar, arrumar todo o material necessário com tempo para o desenvolvimento das atividades em sala de aula". Com isso, percebe-se também que o fator tempo para planejar influencia diretamente na organização do fazer pedagógicos dos professores.

De acordo com o exposto é permissível compreender que as cursistas entenderam a proposta do curso e que o mesmo contribuiu para a organização de seus afazeres docentes alcançando principalmente os alunos em sala de aula através de práticas e instrumentos inovadores.

\section{CONCLUSÃo}

Neste artigo, objetivou-se avaliar o curso de formação continuada "Recursos Tecnológicos e a Organização do Trabalho Docente com Sequências Didáticas" na visão de autores que abordam a temática e professoras cursistas de uma escola pública. Nossa pretensão com o estudo não é de confirmar que esta proposta de formação que envolve trabalho com oficinas em serviço, assessoramentos e inclusão das tecnologias é a panaceia do momento que resolverá a lacuna deixada pela formação inicial do professor. No entanto, segundo os resultados da pesquisa é uma possibilidade que promete revolucionar o campo educacional se vista de forma responsável pela comunidade escolar e o poder público responsável pela referida área.

Ao se propor um curso ao docente amplia-se um conhecimento que geralmente já faz parte do seu cotidiano por já ter tido contato com o mesmo na faculdade. Porém, é necessária a continuidade do processo no local de trabalho do profissional docente. Assim, quando a Divisão de Desenvolvimento do Profissional do Magistério (DDPM) ofereceu o curso "Recursos Tecnológicos e a Organização do Trabalho Docente com Sequencias Didática" buscou-se principalmente conquistar a confiança dos educadores cursistas e adentrar na escola estabelecendo relações entre as teorias que fundamentavam os conteúdos e a prática. Com isso, as oficinas foram desenvolvidas com intuito de demostrar a essência de um trabalho reflexivo e intencional. Junto com o professor num processo mútuo ficou visível que o mesmo pode ser o construtor do próprio conhecimento tendo muito que contribuir com práticas pedagógicas inovadoras a partir também de suas experiências e saberes.

Vale destacar também que não basta estar na escola com o professor e o aluno. É necessário que este profissional tenha tempo para refletir com seus pares sobre os problemas que rondam sua turma, as intervenções que pretende fazer buscando soluções coletivas. Uma prática intencional e reflexiva exige planejamento, pois, o alunado de hoje cobra situações inovadoras. Este público faz parte de um mundo tecnológico, o qual já traz consigo desafios constantes. Entre estes, o manuseio das ferramentas pelo professor que demonstra dificuldades em inseri-los na rotina de sala de aula.

Como sugestão e em prol de uma mudança inicial no fazer pedagógico, recomenda-se à gestão escolar que crie momentos de troca de experiência a partir de formações dentro diretamente no contexto escolar. Sobre tudo as propostas de formações devem vir organizadas dentro do Projeto Político Pedagógico, pois, esta passa a ter uma visão coletiva onde todos os envolvidos poderão levantar problemas, fazer intervenções e o que mais importante focar no que realmente é necessário para o desenvolvimento físico, mental, social e intelectual dos alunos.

Portando, acredita-se que o curso aqui proposto é um bom começo para a concretização da tão sonhada educação de qualidade. Apesar de não ser a exclusiva saída para todos os desafios no contexto escolar e prática docente, ainda é uma atividade fundamental que contribui expressivamente na formação do professor contemporâneo. 
[1] ALONSO, Myrtes. Uma tentativa de redefinição do trabalho docente. São Paulo, 1994.

[2] CAMPOS, Casemiro de Medeiros. Gestão Escolar e Docência. São Paulo: Paulinas, 2010.

[3] CANDAU, Vera Maria (org.) Magistério: Construção Cotidiana. Petrópolis: Vozes, 1997.

[4] COOK-GUMPERZ. Alfabetização e escolarização: uma equação imutável? In: COOK-GUMPERZ, J. (Org.). A Construção Social da alfabetização. Porto Alegre: Artes Médicas, 1991.

[5] DOLZ, Joaquim; NOVERRAZ, Michele; SCHNEUWLY, Bernard. Sequência didática para o oral e a escrita: apresentação de um procedimento. In: SCHNEUWLY, Bernard; DOLZ, Joaquim. Gêneros orais e escritos na escola. São Paulo: Mercado de Letras, 2004.

[6] FERREIRA, Andrea Tereza Brito; ROSA, Ester Calland de Sousa (org.) 0 fazer cotidiano na sala de aula: a organização do trabalho pedagógico no ensino da língua materna. Belo Horizonte: Autêntica, 2012.

[7] GUIMARÃES, Marcelo de Paiva, MOTA Thiago e OLIVEIRA Osvaldo de. Lego Cooperativo: construindo modelos LEGO de forma colaborativa em um ambiente virtual imersivo, interativo sob o paradigma educacional construtivista. 2006 Disponível em: http://revistaseletronicas.pucrs.br/fo/ojs/index.php/hifen/article/view/3778> Acesso em 04 jan. 2013

[8] LEAL, Telma. Organização do trabalho escolar e letramento. In: SANTOS, C. F.; MENDONÇA, M. Alfabetização e letramento: conceitos e reflexões. Belo Horizonte: Autêntica, 2005.

[9] LIBÂNEO, José Carlos. O planejamento escolar. In. LIBÂNEO, José Carlos. Didática. São Paulo: Cortez, 1990.

[10] NÓVOA, António. Os professores e a sua formação. Lisboa: Publicações Dom Quixote/Instituto de Inovação Educacional, 1992.

[11] OLIVEIRA, Maria Marly. Projetos, relatórios e textos na educação básica: como fazer. 2.ed. Petrópolis, RJ: Vozes, 2009.

[12] OLIVEIRA, Z. Creches: crianças faz de conta e cia. Petrópolis: Vozes, 1982

[13] PAVIANI, N. M. S.; FONTANA, N. M. Oficinas pedagógicas: relato de uma experiência. v. 14, n. 2, maio/ago. 2009

[14] PEREIRA, Ieda Lúcia lima. Pedagogia da Prática: propostas para uma educação integral. São Paulo: Gente, 2001.

[15] PERRENOUD, Philippe. A prática reflexiva no ofício do professor: profissionalização e razão pedagógica. Tradução Claudia Schiling. Porto Alegre, Artmed, 2002.

[16] PIMENTA, Selma Garrido. O pedagogo na escola pública: uma proposta de atuação a partir da análise crítica da orientação educacional. São Paulo: Loyola, 1988.

[17] PRENSKY, Marc. Digital Natives, Digital Immigrants. MCB University Press, 2001. Disponível em: .Acesso em: 26 set 2010.

[18] TARDIF, Maurice. Saberes docentes e formação profissional. 14 ed. Petrópolis, RJ: Vozes, 2012.

[19] ZABALA, Antoni. A prática educativa: como ensinar. Trad. Ernani F. da Rosa - Porto Alegre: ArtMed, 1998. 


\title{
Capítulo 22
}

\section{O processo de formação continuada de professores no estado de Goiás: Entre os dispositivos legais e a prática docente cotidiana}

\author{
Hugo Gabriel da Silva Mota \\ Daniel Mallmann Vallerius \\ Leovan Alves dos Santos
}

Resumo: Neste texto discute-se os aspectos legais que regem a formação continuada do professor no Brasil e, mais especificamente, no Estado de Goiás, procurando estabelecer as principais diretrizes e especificidades na legislação que rege o tema, bem como, confrontá- las às demandas mais prementes da sala de aula e do trabalho docente, compreendo que há um hiato entre o que se estabelece nas normativas que regulam a Formação Continuada no Brasil e a realidade vivida pelos professores. Baseando-se em uma pesquisa bibliográfica, este texto estrutura-se em três partes complementares, a saber: na primeira, apresenta-se o contexto teórico que embasa a compreensão de formação continuada de professores, qual seja, uma ação inseparável da atuação docente, efetivada por meio de um conjunto de mecanismos que perpassam a carreira e o trabalho efetivo como professor, exigindo ações colaborativas entre Estado, escolas e professores. Esse debate se estabelece a partir de referenciais teóricos como: Prada (2010; 2007); Libâneo (2004); Cunha (2003) e Candau (1996). Na segunda parte, objetiva-se identificar a concepção de formação continuada embutida nos dispositivos legais, bem como o perfil do professor e de formação continuada que se espera construir com tais regulações e, ainda, a perspectiva educação que se propõem realizar. Neste ponto, recorre-se a Constituição Federal (1988); a Lei de Diretrizes e Bases da Educação Nacional (LDB 9394/96), ao Plano Nacional de Educação (PNE 2014-2018) e a Política Nacional de Formação de Profissionais do Magistério da Educação Básica (2009). Na última parte, procura-se analisar os documentos do Fórum Estadual Permanente de Apoio à Formação Docente - Goiás (FORPROFG0) criado em 2010, com a finalidade de fomentar as condições necessárias para a melhoria da qualidade da formação inicial e continuada dos professores da Rede Estadual de Ensino de Goiás e o documento Pacto Pela Educação, que expressam as principais orientações do Governo de Goiás para a Educação, com suas metas, pilares e objetivos a serem alcançados. Neste momento, procura-se confrontar as definições oficiais acerca da Formação Continuada com a experiência profissional e acadêmica dos autores, afim de estabelecer os elos concordantes e dissonantes desses dispositivos e a realidade docentes.

Nas considerações finais, apresenta-se que no Estado de Goiás, o processo de formação continuada de professores caminha na contramão das perspectivasmais atuais acerca de Formação Continuada, considerando-a sob uma visão utilitarista e mercadológica, reduzindo-a a uma série de ações pontuais e pragmáticas, assemelhando-se a treinamentos para enfrentar demandas específicas previa e externamente definidas, com destaque para a elevação de indicadores de educação como o IDEB (Índice de Desenvolvimento da Educação Básica) como preconiza o documento Pacto pela Educação.

Palavras-chave: Formação Continuada de Professores, Aspectos Legais, Governo de Goiás. 


\section{SITUANDO O DEBATE SOBRE A FORMAÇÃO CONTINUADA DE PROFESSORES}

A acepção da palavra formação, segundo o dicionário Aurélio, é definida como "ação ou efeito de formar, formar-se". Essa concepção compreende a ideia do "inacabado", "em construção" e, neste sentido, a formação de professores pode ser entendida como um

processo contínuo de formação no exercício da profissão.

Considerar o processo de formação do professor como uma atividade em construção coloca em evidência a prática cotidiana na constituição do professor enquanto profissional da educação e, mais, a necessidade da valorização do ambiente escolar como lugar de formação. Esses dois aspectos sustentam este debate sobre a formação continuada de professores que ora se apresenta.

A respeito da formação de professores, Prada (2010, p. 370) afirma:

A formação docente é uma contínua caminhada dos profissionais da educação, em cujo caminhar atuam todas as dimensões individuais e coletivas de caráter histórico, biopsicossocial, político, cultural, próprias dos seres integrais e autores de sua própria formação. (...) a construção da formação docente envolve toda a trajetória dos profissionais, suas concepções de vida, de sociedade, de escola, de educação, seus interesses, necessidades, habilidades e também seus medos, dificuldades e limitações.

Portanto, entendemos que não há neutralidade quando se refere ao processo de formação de professores, tampouco, linearidade nas reflexões dedicadas a compreendê-la e realizar proposições. Assim, neste tema, existem diversas questões que necessitam de aprofundamento, desde a identidade e sentido social da profissão, as condições institucionais em suas múltiplas escalas, até atingir aspectos mais amplos, como: as questões sociais, econômicas, políticas e culturais da atualidade. Todas essas questões influenciam direta e/ou indiretamente o professor e sua atuação profissional e, consequentemente, todo o contexto escolar. Como consequência da multiplicidade de agentes, objetivos e interesses presentes na formação de professores, observa-se que a formação inicial não é suficiente (e também não possui essa pretensão) para dotar o futuro profissional de todas as capacidades, competências e habilidades que o ambiente e o trabalho docente exigem e, por isso, a formação continuada impõem-se como uma necessidade ao efetivo exercício da profissão docente.

Esse entendimento de complementaridade entre o trabalho docente nas escolas e universidades por meio da formação inicial e continuada, atualmente tem balizado as reflexões sobre a formação de professores, sob uma perspectiva de complementaridade entre estas instituições, contrapondo ideias anteriores de subordinação. Assim, Libâneo (2014) destaca,

0 termo formação continuada vem acompanhado de outro, a formação inicial. A formação inicial refere-se ao ensino de conhecimentos teóricos e práticos destinados a formação profissional, completados por estágios. A formação continuada é o prolongamento da formação inicial visando ao aperfeiçoamento profissional teórico e prático, o próprio contexto de trabalho e ao desenvolvimento de uma cultura geral mais ampla, para além do exercício profissional. (p. 227)

Nas universidades além de cursos de especialização, mestrados e doutorados, há também os vários seminários, congressos, simpósios, oficinas, grupos de pesquisa, cursos de extensão e eventos correlatos ${ }^{14}$ que são importantes momentos para formação continuada de professores.

Contudo, a escola também possui lugares e momentos que possibilitam a formação continuada de professores que geralmente não são acessados durante a formação inicial, como as possibilidades de aprendizagem e troca de experiências advindas da relação professor-aluno, das ações didáticopedagógicas diariamente tomadas, do desenvolvimento de projetos, da criação, elaboração e experimentação de materiais didáticos, do contato com professores-estagiários, e também, do efetivo uso do livro didático dentro de sala de aula, e outros diversos temas pertinentes a prática docente e a formação do professor. Do mesmo modo, apresentam-se como elementos formativos do professor, os

\footnotetext{
${ }^{14}$ Neste sentido o Instituto de Estudos Socioambientais da Universidade Federal de Goiás, por meio do Laboratório de Ensino e Pesquisa em Educação Geográfica (LEPEG) e o Núcleo de Ensino e Pesquisa em Educação Geográfica (NEPEG) têm oferecido importantes contribuições à formação continuada dos professores de Geografia de Goiânia e Região Metropolitana, por meio de seminários, cursos de extensão, oficinas didáticas, rodas de conversa com renomados pesquisadores. Esse mesmo grupo realiza o Fórum NEPEG - evento bianual que reúne as principais pesquisas na área do ensino e formação de professores de Goiás e Região Centro-Oeste
} 
tensionamentos que ocorrem dentro do ambiente escolar, como os problemas de infraestrutura humana e material, as situações de indisciplina, de violências, de vulnerabilidades socioeconômicas e emocionais dos alunos, etc.

Dentro dessas questões da realidade docente Cunha (2003, p. 612) destaca que,

[...] é improvável poder abordar a temática da docência separada do lugar em que se produz enquanto profissão. Não há professores no vazio, em uma visão etérea, propondo deslocamentos entre sujeito e contexto. 0 professor se faz professor em uma instituição cultural e humana, depositária de valores e expectativas de uma determinada sociedade, compreendida em um tempo histórico (...)

E, complementando esta ideia de escola como lócus de formação docente, Candau (1996 p. 144) diz,

[...] considerar a escola como lócus de formação continuada passa a ser a afirmação fundamental na busca de superar o modelo clássico de formação continuada e construir uma nova perspectiva na área de formação continuada de professores. Contudo, não se alcança esse objetivo de maneira espontânea, não é o simples fato de estar na escola e desenvolver uma prática escolar concreta que garante a presença das condições mobilizadoras de um processo formativo. Uma prática repetitiva, mecânica, não favorece esse processo. Para que ele se dê é importante que essa prática seja reflexiva, uma prática capaz de identificar os problemas, de resolvê-los, e - as pesquisas são cada vez mais confluentes- que seja uma prática coletiva, uma prática construída conjuntamente por grupos de professores ou por todo o corpo docente de uma determinada instituição escolar.

Assim, compreendemos que se faz necessário um movimento integrado que seja capaz de mobilizar todos os elementos, momentos, lugares, recursos e agentes que participam do processo formativo do professor, a fim de alcançar novos patamares de

qualidade de ensino e formação competente do professor.

Entre os agentes responsáveis ${ }^{15}$ por fomentar o interesse pela formação continuada em serviço dos professores destaca-se o papel de coordenadores pedagógicos e da direção da unidade escolar, que entre outras atividades, devem promover o debate coletivo, a criação de momentos e espaços para estudos e reflexões dentro da escola e, sempre que necessário, tomar as providencias para facilitar a saída destes professores para cursos, seminários, palestras e/ou congressos fora do ambiente escolar ${ }^{16}$.

A principal questão do processo de formação continuada de professores, quando em efetivo exercício da atividade docente, é compreendê-la como uma ação coletiva, entre professores, escola e poder público, refutando o atual cenário que dificulta e, em alguns caso, culpabiliza o professor que a pretende realizar.

\section{ASPECTOS LEGAIS DA FORMAÇÃO CONTINUADA DO PROFESSOR NO BRASIL E EM GOIÁS}

A formação continuada de professores no Brasil surge na agenda nacional com a Lei de Diretrizes e Bases da Educação 5692/71, que estabeleceu como responsabilidade do Estado, por meio das secretarias de ensino, estimular o aperfeiçoamento e a atualização dos professores.

Naquele momento, em plena ditadura militar, a ideia de ensino em vigor primava pela centralidade das políticas públicas e a preocupação com o controle de todas as atividades a serem executadas. Nesse

15 Entre os agentes responsáveis pela formação continuada de professores, deve-se acrescentar o papel das secretarias e redes de ensino que deveriam estimular e promoverem ações e mecanismos para a continuidade da qualificação dos quadros docentes.

16 Neste aspecto chama-se a atenção de todos os professores para as possibilidades e restrições referentes a formação continuada dos professores estabelecidas nos documentos oficiais que regem a profissão em cada munícipio e estado da Federação. 
sentido a formação de professores era entendida como uma prática com um fim em si mesma, ou seja, reduzida a momentos de treinamento, capacitação e atualização de práticas e conteúdos.

A partir da redemocratização do Brasil e a promulgação da Constituição Federal (1988), o país se inscreve em outra perspectiva no que diz respeito aos rumos da educação brasileira. Do centralismo do governo às ações cada vez mais democráticas, da uniformidade de políticas para a heterogeneidade de sujeitos, da excessiva busca pelo resultado para a opção pela construção do conhecimento.

Esse cenário possibilitou que outras demandas fossem postas para a educação e passassem a figurar como leis ordinárias, especialmente no que tange as garantias para o acesso, permanência, financiamento e organização do sistema de ensino.

Na Constituição Federal em vigor, nove artigos se dedicam ao tema da Educação (Art. 205 a 214), onde se estabelecem as linhas gerais que deverão nortear os princípios, objetivos e finalidades deste novo período da educação após a assembleia constituinte. Considerando o objeto de interesse deste texto, destaca-se o artigo 214 da Constituição, que situa o primeiro marco importante a respeito da formação continuada de professores,

Art. 214. A lei estabelecerá o plano nacional de educação, de duração plurianual, visando à articulação e ao desenvolvimento do ensino em seus diversos níveis e à integração das ações do poder público que conduzam à:

I - erradicação do analfabetismo;

II - universalização do atendimento escolar; III - melhoria da qualidade do ensino;

IV - formação para o trabalho;

V - promoção humanística, científica e tecnológica do País. (BRASIL, 1988)

Ao firmar a necessidade da construção de um Plano Nacional com metas definidas, a educação recebe importante atenção, sobretudo, a temática formação de professores, quando o item III do citado artigo, conclama para a melhoria da qualidade da educação no novo modelo de ensino em construção.

Ora, a qualidade do ensino liga-se diretamente a qualidade da formação do docente, suas condições de trabalho e remuneração, num ciclo que se inicia na escola durante a formação básica, avança para a universidade com a graduação e se prolonga durante a formação continuada.

Ao exigir a definição de um Plano Nacional de Educação (PNE), a Constituição Federal determina que sejam empreendidos esforços no sentido de se refletir sobre educação atual e a educação que se pretende alcançar e, para tanto, estabelece o período de 10 anos para a elaboração, aplicação e avaliação dos planos e metas traçadas para a educação. 0 PNE em vigência teve sua redação definida pela Lei 13.005/2014, sendo composto por dez diretrizes principais além de metas específicas a serem alcançadas durante seu período de validade.

No que tange a formação de professores, o PNE (2014-2024), traz metas claras a respeito da necessidade de melhorar a formação inicial como também, ampliar e incentivar a formação continuada de professores, por meio das universidades e centros de ensino e, ainda, por meio das secretarias e redes de ensino além do próprio ambiente escolar.

A respeito da melhoria da qualidade da formação inicial dos professores a meta 13 do PNE assim pretende,

Elevar a qualidade da educação superior e ampliar a proporção de mestres e doutores do corpo docente em efetivo exercício conjunto do sistema de educação superior para $75 \%$ (setenta e cinco por cento), sendo, do total, no mínimo, 35\% (trinta e cinco por cento) doutores (BRASIL, 2014, p. 24).

Compreendemos que a maior qualificação dos professores formadores contribui efetivamente para a redução das dificuldades teórico-metodológicas e conceituais dos professores em formação. Neste sentido, são positivas as políticas públicas dedicadas a ampliar a titulação dos professores universitários. 
Ainda que seja uma medida fundamental a titulação dos professores formadores por si só, não garante a maior qualidade do ensino, mas representam uma importante ação para que se possa construir, entre os futuros professores, novos conhecimentos, práticas e métodos de trabalho, mais eficazes e relacionados com a realidade em que se vai atuar.

Para que esses conhecimentos sejam construídos é imprescindível além da titulação dos professores formadores a articulação destes com programas de ensino-pesquisa-extensão, que fomentam a troca de experiências, elaboração de pesquisas e construção de subsídios que contribuam para o trabalho docente realizado cotidianamente.

Estas possibilidades associadas as melhorias nas condições de trabalho, infraestrutura e remuneração tornam-se ingredientes fundamentais para a elevação da qualidade do ensino em todas as etapas da educação, tanto do Ensino Superior quanto na Educação Básica.

Outra definição importante para a qualidade do ensino no país, está descrita na meta 14 do PNE, que se refere a ampliação do número de matriculados nos cursos de pós- graduação stricto-sensu (mestrados e doutorados), na qual pretende alcançar a formação anual de 60 mil mestres e 25 mil doutores.

Se alcançada as metas de formação de professores mestres e doutores, há de se considerar que tanto Ensino Superior terá um corpo docente mais qualificado quando a própria Educação Básica, pois, observase cada vez mais recorrente o interesse dos professores em cursar a pós-graduação.

Novamente chama-se a atenção para dizer que a ampliação na oferta de vagas para cursos de pósgraduação para professores, representa um grande avanço para a melhoria da qualidade do ensino no país, mas se não for acompanhada de medidas que favoreçam a o acesso e a permanência destes professores da Educação Básica, essas medidas não serão suficientes para alcançar a elevação na qualidade do ensino pleiteada.

Entendemos que é necessário que se criem condições efetivas para que esses profissionais possam permanecer nestes cursos de qualificação, o que implica dizer, a necessidade de facilitar as ofertas de licenças aprimoramento e bolsas de estudos para professores, ou outras medidas que facilitem a redução da carga horária de trabalho, pois conforme pesquisas indicam (MOTA, 2015) a maior parte dos professores do Estado de Goiás trabalham em 2 ou 3 períodos, e assim, cursar a pós-graduação torna-se uma tarefa muito mais difícil.

Considerando efetivamente o interior da escola e os professores que nela atuam a meta 16 do PNE faz referência específica a formação continuada de professores da Educação Básica, que pretende:

Formar, em nível de pós-graduação, 50\% (cinquenta por cento) dos professores da educação básica, até o último ano de vigência deste PNE, e garantir a todos (as) os (as) profissionais da educação básica formação continuada em sua área de atuação, considerando suas necessidades, demandas e contextualizações dos sistemas de ensino (BRASIL, 2014, p. 29)

Como se pode notar, a formação continuada de professores é uma preocupação dos gestores do sistema de ensino no âmbito nacional e isso repercute (ou deveria) nos Estados e Municípios, e se esta medida alcançar êxito, como se espera, terá a qualificação de milhares de professores em todos os lugares deste país, promovendo aulas mais qualificadas, reflexivas, formativas e, assim, escolas, alunos, professores e sociedade em geral serão beneficiados.

Ainda na esfera nacional a legislação maior da educação, a Lei de Diretrizes e Bases da Educação (LDB) 9394/96, também disciplina acerca da formação continuada dos professores.

Art. 62-A. Parágrafo único. Garantir-se-á formação continuada para os profissionais a que se refere o caput, no local de trabalho ou em instituições de educação básica superior, incluindo cursos de educação profissional, cursos superiores de graduação plena ou tecnológicos e de pós-graduação. (BRASIL, 1996)

Neste artigo, entendemos que a LDB 9394/96 avança em dois aspectos: primeiro em garantir a continuidade da formação dos professores e, segundo, ao considerar o próprio ambiente escolar um lugar de formação de professores. 
A conjugação dessas duas políticas públicas, o Plano Nacional da Educação e a Lei de Diretrizes e Bases da Educação 9394/96, suscitaram a instituição da Política Nacional de Formação dos Profissionais do Magistério da Educação Básica, definida no Decreto 6755 de 29 de Janeiro de 2009.

Neste decreto o Governo Federal explicita sua concepção de formação inicial e continuada de professores, como uma prioridade estratégica, constituindo-se em uma política de Estado, por meio de lei própria que o regulamenta e principalmente estabelece obrigações para a União, Estados e Municípios, conforme segue:

Art. 4o A Política Nacional de Formação de Profissionais do Magistério da Educação Básica cumprirá seus objetivos por meio da criação dos Fóruns Estaduais Permanentes de Apoio a Formação Docente, em regime de colaboração entre União, Estados, Distrito Federal e Municípios, e por meio de ações e programas específicos do Ministério da Educação. (BRASIL, 2009).

Entre essas obrigações a Política Nacional de Formação dos Profissionais do Magistério da Educação Básica, estabelece que se construam políticas estaduais de formação de professores, alinhadas as realidades e demandas locais, que serão objeto do próximo item.

\section{A LEGISLAÇÃO REFERENTE A FORMAÇÃO CONTINUADA DE PROFESSORES EM GOIÁS E SEUS REFLEXOS NA PRÁTICA COTIDIANA}

Neste contexto de conjugação de políticas públicas relativas a formação continuada de professores e em resposta Política Nacional de Formação dos Profissionais do Magistério da Educação Básica, o Governo de Goiás institui o Fórum Estadual Permanente de Apoio à Formação Docente - Goiás (FORPROF-GO) em 2010, com a finalidade de criar as condições para a melhoria da qualidade da formação inicial e continuada dos professores da Rede Estadual de Ensino. Entre as atribuições do Fórum Permanente de Apoio a Formação Docente - Goiás destacam-se:

I) Elaboração do plano estratégico de formação docente; II) Articular ações de formação inicial e continuada;

III) Coordenar a elaboração e aprovar as prioridades e metas dos programas de formação inicial e continuada;

IV) Subsidiar os sistemas de ensino para o estabelecimento de prioridades para a participação dos professores em cursos de formação inicial e continuada;

V) Estimular a possibilidade de instituição de grupos de professores em atividades de formação por unidade escolar.

Em sua composição o FORPROF-GO é presidido pela (o) Secretária (o) de Educação do Estado de Goiás e têm como membros os representantes de várias entidades ligadas a formação de professores, como:

a) As instituições de Ensino Superior do Estado de Goiás que oferecem cursos de licenciatura;

b) Dos trabalhadores da educação

c) Do conselho estadual de educação

d) Dos conselhos municipais de educação

e) Do conselho dos dirigentes municipais de educação f) Ministério da Educação. Ainda que a criação deste fórum represente um avanço no processo de valorização e construção de políticas públicas voltadas à formação continuada de professores, na prática suas ações formam bastante tímidas, restritas quase sempre a um plano de ações a ser executado.

Na investigação das atividades do FORPROF-GO, por meio das atas de reunião, verifica-se claramente o caráter eminentemente político deste grupo de trabalho e sua articulação voltada aos interesses e relações institucionais (por vezes individuais e/ou partidárias) em detrimento do universo de professores, seus interesses e necessidades.

A despreocupação com a formação continuada do professor se expressa, entre outros motivos, pela irregularidade das reuniões e a falta de metas, compromissos e prazos claramente estabelecidos, ou ainda, por não cumprir o primeiro item a qual foi criado a "elaboração do Plano Estratégico de Apoio a Formação 
Docente", que segundo a Política Nacional de Formação de Profissionais do Magistério da Educação Básica em seu artigo 5을 deveria contemplar,

I - diagnóstico e identificação das necessidades de formação de profissionais do magistério e da capacidade de atendimento das instituições públicas de educação superior envolvidas;

II - definição de ações a serem desenvolvidas para o atendimento das

necessidades de formação inicial e continuada, nos diferentes níveis e modalidades de ensino; $\mathrm{e}$

III - atribuições e responsabilidades de cada partícipe, com especificação dos compromissos assumidos, inclusive financeiros.

§ $1^{\text {o }} 0$ diagnóstico das necessidades de profissionais do magistério basear- se-á nos dados do censo escolar da educação básica, de que trata o art.

2o do Decreto no 6.425 , de 4 de abril de 2008, e discriminará: I - os cursos de formação inicial;

II - os cursos e atividades de formação continuada;

III - a quantidade, o regime de trabalho, o campo ou a área de atuação dos profissionais do magistério a serem atendidos; e

IV - outros dados relevantes que complementem a demanda formulada. (BRASIL, 2009).

Ao negligenciar a elaboração do Plano Estratégico para a formação de professores no Estado de Goiás toda a educação do Estado, perdeu a oportunidade de construir uma diretriz clara, com metas bem estabelecidas e a atribuição de responsabilidades a cada um dos membros e entidades envolvidos com vistas a promover um real processo de qualificação do ensino em Goiás. Entendemos que na política não há espaços vazios, tão pouco, ações sem intencionalidade e, portanto, a não efetivação deste plano, permite-nos pensar a possibilidade que não há o interesse em discutir e planejar a formação dos professores e a educação de maneira mais ampla no Estado de Goiás, de modo colegiado, sem amarras partidárias e/ou institucionais.

0 desinteresse em construir um plano estratégico suprapartidário e com o pleno envolvimento de diversas instituições ligadas ao ensino e a sociedade em geral, pelo FORPROF-GO, alinhados a um modelo político neoliberal que vê nos números e indicadores as únicas referências para a condução da política educacional, tornam, em nosso entendimento, a educação do Estado de Goiás fragilizada, sobretudo, no que se refere a formação de professores e, passa a simplesmente buscar indicadores esvaziados, sem impactos significativos na aprendizagem e na vida de milhares de estudantes.

\section{CONCLUSÃO}

Entendendo a formação continuada como um ato inerente a profissão docente, configurada como uma verdadeira exigência para a efetivação do trabalho consciente e comprometido, este trabalho, procurou lançar luz sobre a importância de pensar o processo de formação continuada de professores, como uma ação coletiva, entre professor - escola e poder público, para além, dos esforços isolados de cada profissional.

Como se procurou demonstrar, existe um lastro consideração de legislação e marcos oficiais que se ocupam em discutir e garantir a formação continuada de professores no Brasil, contudo, estas mesmas políticas, ao menos no Estado de Goiás, não se configuram como parâmetros para sua efetiva aplicação. Observa-se ainda, uma leniência por parte do Estado e organizações responsáveis pela formação continuada de professores em efetivarem tais políticas, garantindo o direito dos docentes a formação continuada, tanto no sentido horizontal como nos cursos de menor duração, quanto em seu sentido estrito ou verticalizado como mestrados e doutorados.

Assim, entende-se a necessidade da organização dos professores, da continuidade dos debates e, sobretudo, no conhecimento da legislação vigente, como instrumentos de tensão para fazer valer o direito dos professores do Estado de Goiás, como também, uma aproximação ainda maior das instâncias 
formativas do professor, para que se alcance o principal objetivo da educação, o aprendizado qualificado e emancipador do educando.

Compreende-se contudo as dificuldades de efetivação de uma proposta que verdadeiramente estimule o professor da educação básica a buscar os processos de formação continuada, contudo, espera-se que este debate suscite a reflexão teórica dos professores, mas também, acione a dimensão política da profissão. A docência deve ser compreendida com um elemento de atuação política e, tendo a formação continuada como direito, buscar continua e exaustivamente sua efetivação, como medida de reconhecimento e valorização do trabalho docente realizado não somente em Goiás mas em todo o país.

\section{REFERÊNCIAS}

[1] BRASIL. Senado Federal. Lei de Diretrizes e Bases da Educação Nacional: no 9394/96. Brasília: 1996.

[2] BRASIL. Plano Nacional de Educação: nº 13.005/14: Brasília, 2014.

[3] BRASIL. Política Nacional de Formação de Profissionais do Magistério da Educação Básica: no 6755/09: Brasília, 2009.

[4] BRASIL. Rede Nacional de Formação Continuada dos Profissionais do Magistério da Educação Básica Pública: Portaria no 1328/11: Brasília, Ministério da Educação: Brasília, 2011.

[5] BRASIL. Lei 12.796/14. Altera a Lei 9394/96 para dispor sobre a formação dos profissionais da Educação Básica: Brasília, 2013.

[6] CANDAU, Vera Maria Ferrão. Formação continuada de professores: tendências atuais. In. REALI, Aline Maria de Medeiros Rodrigues; MIZUKAMI, Maria da Graça Nicoletti: Formação de professores: tendências atuais: EDUFSCar, São Carlos, 1996.

[7] CUNHA, Maria Isabel. O tema formação de professores: trajetórias e tendências do campo na pesquisa e na ação. Revista Educação e Pesquisa. São Paulo n. 3, pg. 609 - 625, jul/set.

[8] LIBÂNEO, José Carlos. Organização e Gestão da Escola: Teoria e prática. Goiânia. Editora Alternativa, 2004.

[9] MOTA, H. G. S. O livro didático mediando a construção do conhecimento na formação continuada do professor de geografia. 2015. 173 f. Dissertação (Mestrado em Geografia) - Universidade Federal de Goiás, Goiânia, 2015.

[10] PRADA, Luis Eduardo Alvarado, et al. Formação continuada de professores: alguns conceitos, interesses, necessidades e propostas. Revista Diálogo Educação, Curitiba, v. 10, n. 30, p. 367-387, mai/ago. 2010.

[11] PRADA, Luis Eduardo Alvarado. Dever e direito à formação continuada de professores. Revista profissão docente, Uberaba, v.7, n. 16, p. 110-123, ago/dez. 2007. 


\section{Capítulo 23}

\section{As contribuições da metodologia de projetos para a}

construção de saberes significativos e da formação continuada dos professores no contexto das escolas municipais de campo verde

Simoni Pereira Borges

Adriana Sampaio Tibery

Edione Teixeira de Carvalho

Resumo: A presente proposta apresenta uma pesquisa realizada nas escolas municipais do Munícipio de Campo Verde - MT, a qual foi produzida a partir de um olhar sistemático dos trabalhos realizados sob a coordenação da equipe de coordenação de projetos e programas educacionais da Secretaria Municipal de Educação, que acompanhou a implantação e reflexão sobre a prática de trabalhar a partir da metodologia de projetos, investindo na formação continuada de professor e num novo direcionamento das metodologias pedagógicas utilizadas em sala de aula. 0 objetivo da pesquisa foi compreender os impactos e reflexos da formação continuada e da metodologia de projetos para a promoção de práticas significativas no contexto das salas de aula das escolas municipais de Campo Verde-MT. A partir desse repensar e de pesquisas com a rede, percebeu-se que este novo pensar têm impactado em metodologias de ensino diferenciadas, as quais tem demonstrado resultados significativos na aprendizagem dos alunos, assim como, causado impactos importantes na formação dos professores da rede. Com a iniciativa do trabalho com projetos o sistema educacional de Campo Verde iniciou um processo de redefinição de concepções e práticas nas escolas, propondo estudos sobre o currículo, assessoria a professores, momentos de formação e consequentemente uma discussão acerca do protagonismo das crianças nas atividades propostas em sala de aula. A partir daí, este trabalho caracterizase como um estudo científico realizado na rede, utilizando-se de uma pesquisa com abordagem qualitativa, com estudos que evidenciam afirmativas de qualidade no ensino e aprendizagem produzidos nas escolas locais. Os relatos dos professores e alunos ao serem questionados sobre a mudança metodológica descritas neste estudo, apontam elementos marcantes neste processo e, com o trabalho de pesquisa, evidenciou-se a necessidade de investir continuamente nessa discussão acerca da formação profissional e do repensar metodológico no contexto das escolas, rompendo as práticas autoritárias e insignificantes das metodologias verticalizadas para uma prática dialógica, interativa e significativa a partir da execução de projetos e da formação continuada do professor.

Palavras-chave: práticas pedagógicas; metodologias de projetos; aprendizagem significativa. 


\section{INTRODUÇÃO}

Em meio a um cenário educacional repleto de desafios, discutir formação continuada e metodologias ativas como estratégias para dinamizar as aulas é algo necessário. Diante dessa compreensão e observando às demandas das escolas de Campo Verde, vislumbra-se novos investimentos, ações e pesquisas na área de Projetos e da formação continuada dos professores.

Desta forma, a partir de uma conversa com gestores e professores da Rede Pública Municipal de Educação de Campo Verde, iniciaram-se discussões e estudos sobre a necessidade de se repensar as práticas pedagógicas realizadas nas escolas municipais, demonstrando que a metodologia de projetos e o investimento na formação continuada dos professores poderiam impactar em estratégias e métodos de ensino aprendizagem mais coerentes, eficientes e integradores no contexto das escolas da rede municipal de ensino de Campo Verde - MT.

Após investir nesta ação, propôs-se formação continuada aos professores e acompanhou-se as ações da sala de aula. Posteriormente, foi realizado um estudo científico cujo objetivo foi compreender os impactos e reflexos da formação continuada e das metodologias ativas para a promoção de práticas significativas no contexto das salas de aula das escolas municipais de Campo Verde-MT. A problemática que levou a este estudo científico foi a observação de que as crianças e professores, anteriormente ao trabalho com projetos, demonstravam desânimo com suas práticas rotineiras, descontextualizadas e não sabiam como atuar significativamente em sala de aula. Então, indaga-se: os projetos podem contribuir com as questões práticas da relação ensino aprendizagem na sala de aula e com a formação continuada dos professores? Dessa forma, iniciou-se um processo de análise sobre a preparação dos professores para compreenderem novas propostas no cenário local, impactando em metodologias de ensino diferenciadas, as quais têm demonstrado resultados significativos na aprendizagem dos alunos e num novo olhar sobre a prática docente.

Diante do cenário acima apontado foi realizada esta pesquisa com 12 professores e 25 alunos a fim de evidenciar todo o contexto do trabalho realizado na rede apontando os impactos e reflexos que isso tem causado, principalmente na relação ensino aprendizagem.

A pesquisa demonstrou que a iniciativa do trabalho com projetos proporcionou um processo de redefinição de concepções e práticas nas escolas, a partir de estudos sobre o currículo, formação continuada de professores e assessoria aos trabalhos produzidos em sala, visando assegurar a realização de ações a partir de trabalhos concretos e significativos, colocando o professor e o aluno na condição de protagonistas de saberes e práticas contextualizadas. Deixando assim, evidente que este trabalho trouxe impactos significativos, principalmente no contexto da sala de aula.

\section{METODOLOGIA}

Este estudo utiliza-se de uma pesquisa com abordagem qualitativa, aportados por questionários que foram aplicados a professores e alunos que atuam com projetos, identificando quais os impactos significativos dessa metodologia na qualidade do ensino aprendizagem nas escolas locais e na formação continuada de professores, com discussões acerca de metodologias inovadoras, participativas e ativas.

A metodologia qualitativa fez-se necessária por tratar de um estudo que tem como objetivo compreender as relações qualitativas do trabalho realizado pelos professores no contexto das escolas e das salas de aula.

Essa metodologia permite focar no estudo, procurando tratar as analises descritivas, flexíveis e apresentar informações, considerando os integrantes do processo e suas formas de pensar e sentir o problema pesquisado, ficando a cargo do pesquisador realizar análises e sínteses desse processo de forma a descrever e evidenciar as informações encontradas a partir e durante a pesquisa. Por isso, contemplamos as ideias de Bogdan e Biklen (1994), para descrever o suporte metodológico selecionado para este estudo quando descreve a investigação qualitativa em educação,

Os investigadores qualitativos em educação estão continuamente a questionar os sujeitos de investigação, com o objetivo de perceber "aquilo que eles experimentam, o modo como eles interpretam as suas experiências e o modo como eles próprios estruturam o mundo social em que vivem (Psatas, 1973)". Os investigadores qualitativos estabelecem estratégias e procedimentos que lhes permitam tomar em consideração as experiências do ponto de vista do informador (p.51).

Considerando esse marco teórico, justifica-se que os conhecimentos e informações levantadas durante o 
estudo científico, foram analisados, considerando todos os sinais que os cercam, tempo, realidade histórica, política, social, e por isso não esta sendo tratado como verdade absoluta. Neste contexto, as concepções e relações expressas durante o processo são marcas históricas, mutáveis, as quais retratam todas as relações da época vigente no cenário do município. Por isso, a pesquisa qualitativa pode ser entendida como uma possibilidade de transformação da maneira de ser e de se pesquisar em ciências humanas, pois possibilita um trabalho mais reflexivo e interativo do processo, capaz de considerar e adentrar as várias situações postas em seu contexto.

Para atuar no estudo científico foi proposto a aplicação de um questionário semiestruturado aplicado a 25 (vinte e cinco) alunos do Ensino Fundamental, integrantes do projeto, correspondendo uma amostragem do total de alunos que aprendem com a utilização da metodologia de projetos e a entrevista com 12 (doze) professores que também fizeram a habilitação e aderiram voluntariamente a aplicarem a metodologia de projetos em suas salas de aula, assim como, participam de momentos de formação continuada na escola.

É importante afirmar que os participantes desta pesquisa trabalharam a formação e a utilização dessa metodologia nos anos de 2015 a 2017. Ao aluno foi questionado sobre os impactos dessa prática para a melhoria das aulas e aos professores fora discutido como essa metodologia tem impactado na mudança de práticas, concepções e na formação continuada na rede municipal de ensino. Todos os dados levantados foram tabulados e tratados pela pesquisadora, demonstrando os aspectos relevantes.

\section{RESULTADOS E DISCUSSÕES}

Após a coleta dos dados, todo o material foi lido, sintetizado e analisado, observando as questões importantes para a discussão dos resultados. Considerando as respostas dos professores, se apresenta o seguinte resultado: os 12 (doze) professores afirmaram que a partir da proposta de trabalhar com projetos a escola passou a realizar momentos de estudos e reflexões sobre a prática, esses encontros foram realizados pontualmente com uma professora formadora, mestre em educação, a qual potencializava a formação dos professores assim como propunha reflexões sobre a metodologia aplicada. Todos os professores afirmaram que com este trabalho a coordenadora passou a desenvolver melhor suas atividades pedagógicas, acompanhando o trabalho com os professores e a ação do professor passou a ser refletida; 10 (dez) professores responderam visualizar na prática mudanças significativas no contexto de suas salas de aula, tanto nas questões metodológicas quanto na convivência e envolvimento dos agentes no processo (professores e alunos), houve a necessidade de repensar o currículo e um novo olhar sobre o aluno e suas capacidades.

Dos alunos entrevistados, $100 \%$ responderam que gostam de trabalhar com projetos em sala de aula, destes 23 (vinte e três) responderam que com as aulas pensadas a partir de projetos o conteúdo ficou mais interessante e dinâmico; 09 (nove) responderam que conseguem acompanhar as atividades com autonomia, participando das mesmas e discutindo com os colegas, por isso aprendem mais; 25 (vinte e cinco) responderam que aulas assim ficam mais interessantes. Ao serem questionados sobre os impactos que este trabalho tem trazido para a sala de aula, responderam demonstrando que as aulas passaram a ser mais interessantes; 07 (sete) alunos responderam que os professores passaram a considerar mais as ideias deles e, 19 (dezenove) responderam que as aulas deixaram de ser monótonas e diretivas.

\section{CONCLUSÃO}

Pensar em novas práticas docentes e refletir sobre metodologias é um dos caminhos mais importantes da formação continuada dos professores e também da educação. Por isso se realmente a sociedade e a academia vislumbram uma educação de qualidade é necessário investir em estudos, pesquisas e discussões acerca da temática. Ao longo do processo de pesquisa descrito neste trabalho, ficou evidente que os professores perceberam contribuições significativas neste processo, os quais puderam trazer elementos importantes para reelaborarem suas práticas, tais como: reelaboração dos currículos das escolas, momentos de estudos e assessoria do trabalho pedagógico, melhoria na relação professor aluno, um novo olhar sobre o planejamento, o aluno e a sua aprendizagem.

Identificou-se que, os alunos também conseguem descrever com clareza que suas condições foram melhoradas, quando evidenciam o rompimento das práticas autoritárias, verticalizadas e insignificantes em sala de aula por aulas mais participativas e dialógicas, professores mais compreensivos, capazes de entenderem melhor seus alunos, aulas mais interessantes e dinâmicas, e os alunos podendo participar mais ativamente das aulas. 
Todos esses apontamentos retratados ao longo da pesquisa evidenciam que é preciso repensar elementos importantes da educação, criando políticas públicas que assegurem isso de forma a garantir uma educação que assegure a produção de saberes significativos nas escolas e fomente a formação continuada do professor no espaço escolar.

\section{REFERÊNCIAS}

[1] BAUER. Martin W., GASKELL, George. Pesquisa qualitativa com texto, imagem e som. 7a ed. Rio de Janeiro: Editora Vozes, 2008.

[2] BOGDAN, R.; BIKLEN, S. Investigação qualitativa em educação. Porto: Porto Editora, 1994.

[3] FREIRE, Paulo. Pedagogia do Oprimido. Rio de Janeiro: Paz e Terra: 1978.

[4] MORIN, Edgar. Educação e complexidade: os sete saberes e outros ensaios. Maria da Conceição de Almeida, Edgar de Assis Carvalho (orgs.). 3ํㅡㄹ edição. São Paulo: Cortez, 2005.

[5] NOVOA, Antônio. Formação de professores e trabalho pedagógico. Lisboa: Educa. 2002.

[6] PERRENOUD, Philippe. A prática reflexiva no ofício de professor: profissionalização e razão pedagógica. Trad. Claudia Schilling. Porto Alegre: Artemed, 2002.

[7] PIMENTA, S. G. e GHEDIN, E. (Orgs.) Professor reflexivo no Brasil. Gênese e crítica de um conceito. São Paulo: Cortez Editora, 2006.

[8] TORRES, Rosa Maria. A educação em função do desenvolvimento local e da aprendizagem. In: Muitos lugares para aprender. Centro de Estudos e Pesquisas em Educação, Cultura e Ação Comunitária - CENPEC - São Paulo: CENPEC/Fundação Itaú Social /Unicef, 2003. 


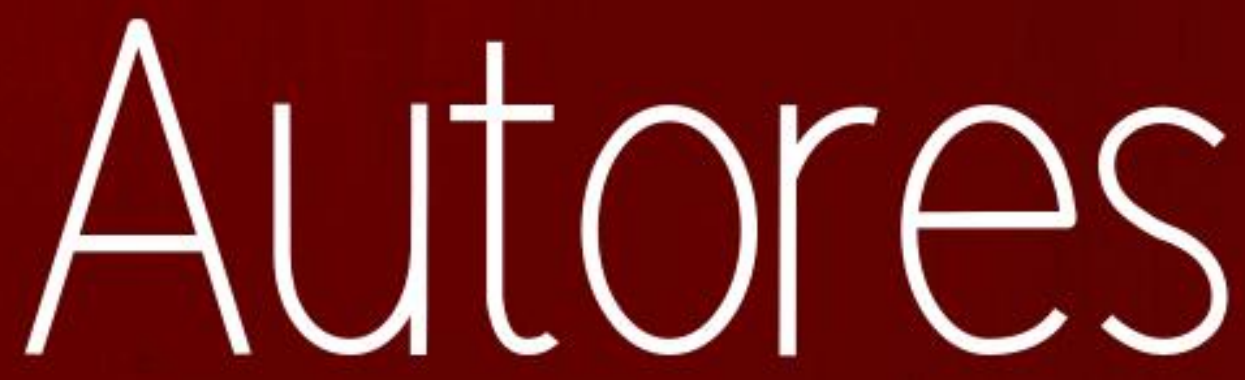




\section{ADRIANA NEVES DE ALMEIDA}

Possui Mestrado Profissional em Ensino Tecnológico pelo Instituto Federal de Educação, Ciência e Tecnologia do Amazonas (IFAM) e Graduação em Licenciatura em Pedagogia pela Universidade do Estado do Amazonas (UEA). É servidora efetiva do IFAM, atuando como pedagoga no Departamento Acadêmico de Informação e Comunicação do Campus Manaus Centro, e investiga sobre Formação de Professores e a Integração de Tecnologias no processo de ensino e aprendizagem.

\section{ADRIANA SAMPAIO TIBERY}

Graduada em Geografia e Pedagoga ( Habilitação Administração Escolar, Orientação Educacional e Supervisão Escolar). Especialista em Arte, Educação e Tecnologias Contemporâneas - Arteduca UNB (2006). Mestre em Educação - Universidad de Los Pueblos de Europa (2014). Diretora Geral Faculdade Albert Einstein - FALBE e Instituto de Educação Superior Albert Einstein - ISALBE.

\section{ALDEMIRA DE ARAÚJO CÂMARA}

Cursando o Mestrado Profissional em Ensino Tecnológico no Instituto Federal de Educação, Ciência e Tecnologia do Amazonas-IFAM. Graduada em PEDAGOGIA com habilitação em Supervisão Escolar e Orientação Educacional pela Universidade Federal do Amazonas. Especialista em Gestão em Educação pela Universidade Federal do Amazonas. Especialista em Coordenação Pedagógica pela Universidade Federal do Amazonas. Especialista em Tecnologias em Educação pela PUC/RIO. Professora e Pedagoga efetiva da Secretaria Municipal de Educação de Manaus (SEMED), atualmente como Gerente na Gerência de Tecnologia Educacional (GTE) setor responsável pela formação continuada de professores da rede municipal de ensino quanto a inserção das tecnologias no processo de ensino e aprendizagem. Experiência na área de Educação, atuando nos seguintes temas: Educação, Tecnologias na Educação, Aprendizagem e Educação a Distância.

\section{AMANDA NASCIMENTO SILVA DE OLIVEIRA}

Pedagoga formada pela Universidade Federal de Pernambuco-Centro Acadêmico do Agreste. Pós graduada em Coordenação Pedagógica pela Faculdade Educacional da Lapa ( FAEL). Foi professora das séries iniciais do Ensino Fundamental em uma escola do campo no Município de Caruaru-PE de 2009 a 2017. Foi supervisora do PIBID-Pedagogia 2015-2018. Integrante do grupo de estudos em Educação do Campo (Gee Campo), pela UFPE-CAA. Atualmente coordenadora da Escola Municipal Professora Maria de Lourdes Pepeu, localizada na área campesina de Caruaru-PE.

\section{AMANDA TAYSE DE SENA SILVA SANTOS}

Graduada em Pedagogia pela Universidade Estadual da Paraíba (UEPB). Atualmente professora de Educação Infantil na Escola Bem Crescer.

\section{ANA CLÁUDIA RIBEIRO DE SOUZA}

Doutorado em História Social pela Pontifícia Universidade Católica de São Paulo. É professora permanente no Mestrado Profissional em Ensino Tecnológico e do Mestrado Profissional em Educação, Profissional e Tecnológica, do Instituto Federal do Amazonas, no qual é professora Titular, na linha de pesquisa Processos Formativos de Professores no Ensino Tecnológico realizando projetos que visam promover discussões acerca da produção do conhecimento no Brasil, e mais especificamente na Amazônia, no que tange o desenvolvimento científico e tecnológico na sua interface de com as questões urbanas. 


\section{ANDRÉ FILLIPE DE FREITAS FERNANDES}

Mestrando do Programa de Pós-Graduação em Divulgação da Ciência, Tecnologia e Saúde pela Fundação Oswaldo Cruz - COC/Fiocruz. Concluiu a graduação em Ciências Biológicas pela Universidade do Estado do Rio de Janeiro (UERJ). Atuou em projetos de ensino através do Programa Institucional de Bolsas de Iniciação à Docência no Subprojeto de Biologia (PIBID/Capes/UERJ). Desempenhou atividades como mediador e no desenvolvimento de projetos de divulgação científica em centros de ciências, museus e exposições itinerantes. Atualmente suas linhas de pesquisa tem sido em divulgação científica, educação especial, ensino de Ciências e Biologia.

\section{ANNA RAQUEL DA SILVA MARINHO}

Licenciada em Informática pelo Instituto Federal de Educação, Ciência e Tecnologia do Rio Grande do Norte (IFRN), Campus Natal - Zona Norte (2018). Pós-graduanda em Psicopedagogia (UNINASSAU). Atualmente professora de Robótica Educacional da Educação Básica - Anos Iniciais.

\section{CELI DA COSTA SILVA BAHIA}

Graduada em Pedagogia pela Universidade Federal do Pará. Doutora em Teoria e Pesquisa do Comportamento Humano pela Universidade Federal do Pará (UFPA). Professora no Curso de Pedagogia do Instituto de Ciências da Educação da UFPA. Coordenou o Programa de Formação de Professores em Educação Infantil (PROINFANTIL) nos estados do Amazonas e Pará, no período de 2008 a 2010. Coordenadora geral do Grupo IPE. Desenvolve pesquisas na área da educação infantil. Estuda principalmente a educação de bebês, currículo da educação infantil, formação de professores de educação infantil, organização do tempo-espaço na educação infantil. Consultora ad hoc de várias revista

\section{CLAUDIA CHRISTINA BRAVO E SÁ CARNEIRO}

Engenheira química pela UFC; química, pela UFC; mestre em química inorgânica pela UFC; Doutora em educação brasileira pela UFC; Pós-Doutora em Educação pela UnB; professora aposentada do departamento de química orgânica e Inorgânica da UFC; Professora, pesquisadora e orientadora do Programa de pós-graduação em educação brasileira - Faced - UFC; líder do Grupo de estudos e pesquisas em Ensino de Ciências - GEPENCI- CNPq.

\section{DANIEL MALLMANN VALLERIUS}

Doutor em Geografia pela Universidade Federal de Goiás com doutorado-sanduiche na Universidad de Sevilla (Espanha). Mestre em Geografia pela Universidade Federal do Rio Grande do Sul. Licenciado em Geografia pela UFRGS com graduação-sanduíche na Central Connecticut State University/EUA. Foi professor da Rede Municipal de Educação de Porto Alegre/RS e de organizações de educação popular. É professor adjunto da Universidade Federal do Pará (Campus Altamira), onde coordena o PIBID Geografia, o Laboratório de Prática de Ensino de Geografia (LabPrat) e os estágios supervisionados de licenciatura. Membro do Núcleo de Ensino e Pesquisa em Educação Geográfica (NEPEG). Pesquisa na área de formação de professores, estágio supervisionado e educação cidadã.

\section{DÉBORA DE AGUIAR LAGE}

Doutora em Biologia Vegetal pela Universidade do Estado do Rio de Janeiro (PGBV/UERJ), com Mestrado em Biologia pela Universidade do Estado do Rio de Janeiro (PPGB/UERJ). Professora Adjunta da Universidade do Estado do Rio de Janeiro, lotada no Instituto de Aplicação Fernando Rodrigues da Silveira (CAp-UERJ). Docente do Mestrado Profissional em Ensino de Biologia (PROFBIO). Atuou como coordenadora do subprojeto de Biologia do Programa Institucional de Bolsas de Iniciação à Docência (PIBID/Capes/UERJ) durante seis anos. Participa de projetos de pesquisa e orientação nas áreas de Ensino de Ciências e Biologia, Alfabetização científica, Divulgação científica, Educação especial e Botânica. 


\section{EDILSON DE ARAÚJO DOS SANTOS}

Graduação em Pedagogia pela Universidade Estadual de Maringá (UEM), mestrando no Programa de Pós-Graduação em Educação (PPE/UEM). É membro do Grupo de Pesquisa e Ensino "Trabalho Educativo e Escolarização" (GENTEE/UEM).

\section{EDIONE TEIXEIRA DE CARVALHO}

Licenciada em Geografia pela Faculdade de Educação Ciências e Letras de Iporá (1996), especialista em Docência Universitária pela Universidade Católica de Goiás (1998) e doutora em Ciências Pedagógicas pela Universidad Central Marta Abreu de Las Villas - Cuba (2007), revalidado no Brasil pela Universidade Federal da Bahia (UFBA). Atualmente é professora do Instituto Federal de Mato Grosso, campus São Vicente, professora do Mestrado em Ensino do IFMT parceria com o Grupo KROTON. Avaliadora dos cursos PRONATEC, consultora Ad Hoc da das Revistas RBEP INEP, REVISTA FACISA, SIG FAPEMAT, membro do Consejo Iberoamericano de Honor a la Calidad Educativa, com sede em Lima-Peru. Possui larga experiência em docência, atuando principalmente nos seguintes temas:Superação profissional, educação ambiental, processo docente educativo, formação ambiental e cultura ambiental, Motivação e Proatividade.

\section{FRANCISCO DAS CHAGAS DA SILVA JUNIOR}

Possui Graduação em Engenharia de Computação (2003), Mestrado em Engenharia Elétrica (2005) e Doutorado em Engenharia Elétrica (2017) pela Universidade Federal do Rio Grande do Norte. Desde 2006, é professor do Instituto Federal de Educação, Ciência e Tecnologia do Rio Grande do Norte (IFRN). Esteve lotado no Campus Currais Novos até 2010 e atualmente está lotado no Campus Natal - Zona Norte, onde é coordenador do curso de Licenciatura em Informática. Tem experiência na área de Engenharia Elétrica, com ênfase em Automação Eletrônica de Processos Elétricos e Industriais. Tem interesse e ministra disciplinas nas áreas de Lógica Computacional, Programação de Computadores, Pensamento Computacional, Informática na Educação e Ensino de Informática.

\section{GIVANALDO ROCHA DE SOUZA}

Doutor em Ciência da Computação, Engenheiro de Computação e Tecnólogo em Informática. É professor do Campus Parnamirim do IFRN e trabalha com pesquisa e extensão nas áreas de Desenvolvimento de Sistemas, Inteligência Computacional e Informática Educacional.

\section{HUGO GABRIEL DA SILVA MOTA}

Doutorando em Geografia IESA/UFG (2018). Mestre em Geografia - IESA/UFG (2015). Graduado em Geografia pela Universidade Federal de Goiás (2009). Professor efetivo da Secretaria Municipal de Goiânia (2009). Membro do GECE - Grupo de Estudos e Pesquisas de Cartografia para Escolares (2018) e do Núcleo de Ensino e Pesquisa em Educação Geográfica (NEPEG), desde 2018. Áreas de interesse de pesquisa e atuação: Formação Continuada de Professores de Geografia, Livro Didático, Ensino de Geografia e Cartografia Escolar.

\section{IEDA LUCIA DE OLIVEIRA SANTANA}

Mestrado em Ensino Tecnológico pelo Instituto Federal de Educação, Ciência e Tecnologia do Amazonas (IFAM). Especialização em Mídias na Educação (2010) pela Universidade Federal do Amazonas (UFAM) e em Informática e Educação (2003) pelo Instituto Cultural de Ensino Superior do Amazonas (ICESAM); Graduação em Comunicação Social (2000) e em Letras (1995) pela Universidade Federal do Amazonas (UFAM). Experiência na área de Educação, atuando como Instrutor Educacional na Gerência de Tecnologia Educacional/SEMED e professora na Secretaria de Estado de Educação e Qualidade do Ensino (SEDUC). 


\section{ISABEL DE CARVALHO PAIVA}

Graduanda em Pedagogia pela Universidade Estadual do Ceará - UECE; bolsista do Programa Educação Tutoria - PET, da Faculdade de Educação de Crateús - FAEC campus UECE em Crateús. Atuou como bolsista no Programa Institucional de Bolsas de Iniciação à Docência (Pibid) no período correspondente a abril de 2016 a março de 2018, cumprindo carga horaria na Escola de Cidadania Olavo Bilac - Crateús, espaço de observações e coparticipações na sala de aula com turmas de $2^{\circ}$ ao $4^{\circ}$ ano, desenvolvendo estudos em grupo, experiência em sala de aula, oficinas e clube de leitura. Atualmente é bolsista do Programa Educação Tutorial, subprojeto PET da Faculdade de Educação de Crateús - FAEC (PET/FAEC - UECE) cujo objetivo é a Educação Contextualizada para convivência com o Semiárido Brasileiro, os trabalhos centralizam-se no acompanhamento das ações pedagógicas, formações e pesquisas de campo nas escolas dos municípios dos sertões de Crateús - CE, no acompanhamento ao Projeto Contexto da Rede de Educação do Semiárido Brasileiro (RESAB) e parceria com a Cáritas Diocesana de Crateús (CDC). Graduação em andamento em Pedagogia. Universidade Estadual do Ceará, UECE, Brasil. Faculdades de Educação de Crateús - FAEC.

\section{IZABEL SILVA BRAGANÇA PINHEIRO}

Especialista em Psicopedagogia na Faculdade Salesiana Dom Bosco, Graduada em Licenciatura em Ciências Naturais na Universidade Federal do Amazonas - UFAM. Professora de alfabetização da Secretaria Municipal de Educação - SEMED.

\section{JANAINA BONIATTI BOLSON}

Possui Doutorado em Educação pela Universidade do Vale do Rio dos Sinos(2016); Mestrado em Educação pela Universidade do Vale do Rio dos Sinos (2011); Pós-Graduação em Administração e Supervisão Escolar pela Universidade do Vale do Rio dos Sinos (1999): Graduação em Pedagogia pela Universidade de Caxias do Sul (1996). Atualmente é professora da FAMUR - Faculdade Murialdo de Caxias do Sul no Curso de Pedagogia e do IFRS - Campus Bento Gonçalves no Curso de Pedagogia - PARFOR. Professora dos Anos Iniciais na E.M.E.F Machado de Assis no município de Caxias do Sul. Também é membro da ASSERS - Associação de Supervisores Educacionais do Rio Grande do Sul. Tem experiência na área da Educação em Séries Iniciais e Finais do Ensino Fundamental e Ensino Médio e disciplinas pedagógicas de formação de professores.

\section{JANIELE DA SILVA COSTA}

Graduanda do Curso de Licenciatura em Informática pelo IFRN. Atuou como instrutora em cursos de Informática voltados para qualificação profissional pela Secretaria de Trabalho e Assistência Social da Prefeitura de Natal/RN. Já foi bolsista do Programa Institucional de Bolsas de Iniciação à Docência (PIBID), no qual participou de projetos de Inclusão digital e de Iniciação à programação, voltados para a Rede Pública de Ensino de Natal/RN. É membro do Núcleo de Atendimento às Pessoas com Necessidades Educacionais Especiais (NAPNE) do Campus Natal - Zona Norte do IFRN, assim como também foi monitora da disciplina de Educação Inclusiva do Curso de Licenciatura em Informática.

\section{JAQUELINE BATISTA DE OLIVEIRA COSTA}

Possui Doutorado em "Educação: Psicologia da Educação" pela Pontifícia Universidade Católica de São Paulo - PUC/SP (2011; Mestrado em Educação: "Formação de Professores" pela Universidade Estadual Paulista Júlio de Mesquita Filho de Presidente Prudente - UNESP/SP (2004). É formada em Pedagogia pela Universidade Estadual Paulista Júlio de Mesquita Filho de Presidente Prudente (2000) e, atualmente está concluindo o curso de Bacharelado e Licenciatura em Psicologia pelo Centro Universitário da Grande Dourados (UNIGRAN) (2019). Atua como Professora Adjunta do Curso de Graduação e Pós-Graduação (Mestrado) em Psicologia na Universidade Federal da Grande Dourados - UFGD, (Dourados/MS). 


\section{JOSIANO REGIS CARIA}

Cursando Doutorado em Humanidades e Artes na Universidade Nacional de Rosário na Argentina, Licenciado em Letras - Língua Portuguesa pela UFAC com especialização em Informática e Educação pelo Sociedade do Desenvolvimento Cultural do Amazonas - SODESCAM. Mestre em Ensino de Ciências pela UEA. Atuando como Instrutor Educacional e um dos Coordenadores do Clube de Letramento em Programação e Robótica-PROCURUMIM da Gerência de Tecnologia Educacional - GTE/ Divisão de Desenvolvimento Profissional do Magistério - DDPM/Secretaria Municipal de Educação - SEMED.

\section{JULIANA PEREIRA GUIMARÃES}

Possui curso de Magistério - Educação Infantil Series Iniciais (2009). Graduação em Artes Visuais Licenciatura pela Universidade do Extremo Sul Catarinense - Unesc (2013). Especialista em Arte e Educação (2013) Especialista na Educação na Cultura Digital (2015 - UFSC), Mestrado em Educação (2018) Universidade do Extremo Sul Catarinense - Unesc. Professora de Artes do Colégio Unesc. Professora do Curso de Artes Visuais Licenciatura Unesc. Participa do Grupo de Estudos do Arte na Escola Polo Unesc.

\section{KARLA JEANE COQUEIRO BEZERRA SOARES}

Mestra em Ensino de Ciências e Matemática pela Universidade Federal do Maranhão (UFMA) na linha de Pesquisa, Ensino aprendizagem e formação professores. Graduada em Ciências Biológicas pela UFMA. Atualmente é membro do Grupo de Pesquisa em Ensino de Ciências e Biologia (GPECBio) e do Grupo de Pesquisa Ensino de Ciências, Saúde e Sexualidade (GPENCEX). Desenvolve estudos na área da educação com temas relacionados a Formação de professores, Saberes docentes, Identidade profissional, Alfabetização Científica, Práticas discursivas e Ensino de Ciências e Biologia.

\section{LEIDA GILVANE CANTALICE RIBEIRO}

Cursando Mestrado em Educação Universitária na Universidade Nacional de Rosário na Argentina, Graduada em Normal Superior pela Universidade do Estado do Amazonas e em Língua Portuguesa pelo Centro Universitário Leonardo da Vinci, com especialização em Psicopedagogia na Faculdades Salesianas Dom Bosco e Alfabetização e Letramento pela Faculdade Educacional da Lapa-FAEL. Atuando como Instrutor Educacional e uma das Coordenadoras do Clube de Letramento em Programação e Robótica-PROCURUMIM na Gerência de Tecnologia Educacional-GTE/Divisão de Desenvolvimento Profissional do Magistéiro - DDPM/Secretaria Municipal de Educação - SEMED.

\section{LEOVAN ALVES DOS SANTOS}

Doutorando em Geografia pela Universidade Federal de Goiás. Graduação e mestrado em Geografia pela Universidade Federal de Goiás. Especialista em Psicopedagogia Institucional e Gestão e Educação Ambiental pela Faculdade Alfredo Nasser. Lecionou na rede particular de ensino de Goiânia e é atualmente professor efetivo das redes de ensino do município de Goiânia (SME) e da rede Estadual de Goiás (SEDUC-GO). É membro integrante da Rede de Pesquisa em Ensino de Cidade (REPEC); do Núcleo de Estudos e Pesquisas de Educação e Cidade (NUPEC); e do Núcleo de Ensino e Pesquisa em Educação Geográfica (NEPEG). Bolsista da Fundação de Amparo à Pesquisa do Estado de Goiás (Fapeg).

\section{LUCIANA FIGUEIREDO LACANALLO ARRAIS}

Doutora em Educação pela Universidade Estadual de Maringá (UEM), professora adjunta do Departamento de Teoria e Prática da Educação (DTP/UEM), e é membro do Grupo de Pesquisa e Ensino "Trabalho Educativo e Escolarização" (GENTEE/UEM). Coordenadora do PIBID/UEM/subprojeto Pedagogia. 


\section{LUCIANI ANDRADE DE ANDRADE}

Formada em Administração de Empresas pela UFAM - Universidade Federal do Amazonas, Mestre em Ensino Tecnológico pelo IFAM - Instituto Federal de Educação, Ciência e Tecnologia do Amazonas. Professora do Ensino Básico e Tecnológico no Instituto Federal de Educação, Ciência e Tecnologia do Amazonas, campus Presidente Figueiredo.

\section{LUIZ ANSELMO MENEZES SANTOS}

Doutor e Mestre em Educação pela Universidade Federal de Sergipe. Licenciado em Educação Física pela UFS. Professor Associado do Departamento de Educação Física da UFS. Professor do Programa de Pós-Graduação em Educação. Coordenador do grupo de pesquisa Formação e Atuação de Educadores - INTERAÇÃO. Tem experiência na área de Filosofia da Educação, Didática, Formação de Professores, Educação Física Escolar. Autor do livro 0 corpo próprio como princípio educativo: a perspectiva de Merleau-Ponty. Curitiba: Appris, 2016

\section{MANUELLA PATRICIO MENEZES}

Graduada em Pedagogia pela Universidade Estadual da Paraíba (UEPB). Especialista em Psicopedagogia, cursando Neuropsicopedagogia. Atualmente atende no espaço Aprender.

\section{MARIA DA CONCEIÇÃO CARRILHO DE AGUIAR}

Possui graduação em Pedagogia pela Universidade Federal de Pernambuco (1980), mestrado em Educação pela Universidade Federal de Pernambuco (1997), doutorado em Ciências da Educação pela Universidade do Porto / Portugal (2004), Pós-doutorado em Ciências da Educação pela Universidade do Porto / Portugal. Atualmente é Professor Associado da Universidade Federal de Pernambuco. Atua no Programa de Pós-Graduação em Educação como pesquisadora da Linha de Pesquisa em Formação de Professores e Prática Pedagógica e na Graduação do Curso de Pedagogia e das Licenciaturas Diversas. Tem experiência na área de Educação, com ênfase em Gestão Escolar, Coordenação Pedagógica, Planeamento Educacional, Organização da Educação Escolar Brasileira, Pesquisa e Prática Pedagógica atuando principalmente nos seguintes temas: formação de Professores, identidade e profissionalização docente, Docência no Ensino Superior e com a Teoria das Representações Sociais. Membro do Núcleo de Formação Didático-Pedagógica dos Professores da UFPE - NUFOPE. Editora chefe da Revista de Administração Educacional do Departamento de Administração Escolar e Planejamento Educacional do Centro de Educação da UFPE.

\section{MARIA DO SOCORRO MOURA MONTENEGRO}

Doutora em Linguística pela UFPB, Mestrado em Educação pela UNICAMP, Professora no Departamento de Educação da Universidade Estadual da Paraíba, desenvolve pesquisas na área de leitura, escrita e alfabetização.

\section{MARIA ELBA SOARES}

Graduada em História pela Universidade Estadual do Ceará (1995), mestrado em Educação pela Universidade Federal do Ceará (2013). Doutoranda em Educação pela Universidade Federal do Ceará (início em 2015.2). Supervisora Pedagógica - Colégio Santa Cecília. Professora da pósgraduação da UNI7-Centro Universitário 7 de Setembro. Integrante do Grupo de Estudos e Pesquisa em Ensino de Ciências - GEPENCI (UFC). Experiência na acadêmica e escolar. Atua principalmente nos seguintes temas: Educação, Formação de Professores, Currículo e Supervisão Pedagógica. 


\section{MARIA ESTELA COSTA HOLANDA CAMPELO}

Professora Titular do Departamento de Fundamentos e Políticas da Educação do Centro de Educação da Universidade Federal do Rio Grande do Norte (UFRN). Graduada em Pedagogia e Mestre em Educação pela UFRN. Doutorado em Educação pelo Programa de Pós-graduação em Educação da UFRN, com Estágio Doutoral em Educação, desenvolvido com bolsa da CAPES na Universidade de Lisboa (Portugal). No Ensino, tem ministrado as disciplinas Alfabetização e Letramento, Seminário de Pesquisa, Aprendizagem e Desenvolvimento da Linguagem e Psicologia da Educação, dentre outras. Suas publicações têm versado sobre as temáticas de suas investigações que têm como fio condutor o compromisso político de contribuir para o sucesso escolar da escola pública brasileira.

\section{MARIA JOSELMA DO NASCIMENTO FRANCO}

Professora associada no Programa de Pós-graduação em Educação Contemporânea da Universidade Federal de Pernambuco (UFPE) - Centro Acadêmico do Agreste em Caruaru (CAA). Doutora em Educação, pela Universidade de São Paulo. Participante do Núcleo de Pesquisa, Extensão e Formação em Educação do Campo na UFPE; vice-líder do Grupo de Pesquisa em Ensino, Aprendizagem e Processos Educativos (GPENAPE), pesquisadora do Núcleo de Estudos e Pesquisas sobre Desenvolvimento Profissional Docente da Pontifícia Universidade Católica de São Paulo, ambos credenciados pelo Conselho Nacional de Desenvolvimento Científico e Tecnológico.

\section{MARIA PAULA FERREIRA MAIA DA SILVA}

Professora de Educação Infantil na Secretaria Municipal de Educação de Belém - Pará. Especialista em Docência na Educação Infantil pela Universidade Federal do Pará (UFPA).

\section{MARIANA GUELERO DO VALLE}

Professora do Departamento de Biologia da Universidade Federal do Maranhão (UFMA). Doutora

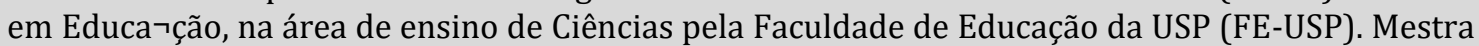
em Educação (FE-USP) e licenciada em Ciências Biológicas pela Universidade de São Paulo (FFCLRP/USP). Professora dos Programas de Pós-Graduação em Ensino de Matemática e Ciências (PPCEM) e Gestão de Ensino da Educação Básica (PPGEEB), ambos da Universidade Fede $\neg$ ral do Maranhão (UFMA). É Coordenadora do Grupo de Pesquisa em Ensino de Ciências e Biologia (GPECBio), da UFMA.

\section{MILENE MÍRIAN ARAÚJO MONTEIRO}

Mestrado em Letras e Artes pela Universidade do Estado do Amazonas - UEA, Graduada em Educação Artística com Habilitação em Música pela Universidade Federal do Amazonas - UFAM. Especialista em Tecnologias na Educação pela Pontifícia Universidade Católica do Rio de Janeiro PUC-RJ e em Docência em EAD pela Escola Superior Aberta do Brasil - ESAB. Atualmente Instrutora Educacional na área de tecnologias educacionais para professores da Rede Municipal de Ensino e uma das coordenadoras do Clube de Letramento em Programação e Robótica - Procurumim da Gerência de Tecnologia Educacional - GTE/ Divisão de Desenvolvimento Profissional do Magistéiro - DDPM/Secretaria Municipal de Educação - SEMED.

\section{MIRELLA INGRID OLIVEIRA DA CRUZ}

Graduanda em Matemática Licenciatura pela UFRN. Participou do Programa Institucional de Bolsa de Iniciação à Docência -Matemática/UFRN, atualmente atua com Professora Residente do Programa Residência Pedagógica - Matemática/UFRN. 


\section{NÉRYLA VAYNE ALVES DIAS}

Licenciada em Física (2007) pela Universidade Estadual Paulista “Júlio de Mesquita Filho - UNESP. Mestre em Educação (2014) e Doutoranda em Educação no Programa de Pós- graduação em Educação da Universidade Estadual Paulista "Júlio de Mesquita Filho - UNESP. Professora colaboradora na Universidade Estadual de Maringá (UEM). Membro do grupo de Pesquisa "Formação de professores de Ciências Naturais"; Membro do Grupo de Extensão "Escolas na UEM". Atua principalmente nos temas: formação de professores, ensino de física, relação com o saber, currículo e integração universidade-escola.

\section{PATRICIA REGINA DE SOUZA}

Licenciada em Pedagogia pela Universidade Estadual Paulista Júlio de Mesquita Filho (UNESP). Mestre em Educação (2019) e Doutoranda do Programa de Pós-Graduação em Educação (PPGE) da FCT/UNESP, desenvolvendo pesquisa na linha "Processos formativos, Ensino e Aprendizagem", com ênfase no ensino e aprendizagem da língua portuguesa. Membro do grupo de pesquisa Formação de Professores e Práticas de Ensino na Educação Básica e Superior (GP- FPPEEBS). Tem experiência na área de Educação, com ênfase no ensino e aprendizagem da língua portuguesa, atuando principalmente nos seguintes temas: ensino de ortografia, produção textual, regularidades e irregularidades ortográficas e variação linguística.

\section{PAULEANY SIMÕES DE MORAIS}

Possui graduação em Pedagogia pela Universidade Federal do Rio Grande do Norte (2004) e Mestrado em Educação pela Universidade Federal do Rio Grande do Norte (2006). Doutora em Educação pelo Programa de Pós-graduação da Universidade Federal do Rio Grande do Norte (2012). Atualmente é professora efetiva do Instituto Federal de Educação, Ciência e Tecnologia do Rio Grande do Norte (IFRN). Tem experiência na área de Educação, com ênfase em política educacional, gestão escolar e ensino de computação, atuando principalmente nos seguintes temas: órgãos colegiados, participação, relações de poder e formação de professores em computação.

\section{PÉROLA DIANA GOMES FELIPE}

Graduada em Ciências Contábeis pela UFRN. Licencianda em Matemática pela UFRN. Professora Residente do Programa Residência Pedagógica - Matemática/ UFRN. Professora Particular de Matemática

\section{PRISCILA VARGAS GATTI}

Mestranda em Psicologia pela Universidade Federal da Grande Dourados (UFGD). Cursando especialização em Psicologia Clínica - Terapia Cognitivo-Comportamental pela Universidade de Araraquara (UNIARA). Bacharel e licenciada em Psicologia pela Universidade Federal da Grande Dourados (UFGD).

\section{QUEREM APUQUE FELIX DE ANDRADE}

Graduação em Engenharia de Materiais pela Universidade Federal do Rio Grande do Norte, Mestre em Ciência e Engenharia de Materiais pelo Programa de Pós-graduação em Ciência e Engenharia de Materiais - UFRN. Voltou a vida acadêmica para cursar Matemática Licenciatura, apaixonando-se pela docência nos primeiros meses do curso. Iniciou com bolsista do Programa Institucional de Bolsas de Iniciação à Docência- Matemática/UFRN no segundo semestre de 2018, contribuindo junto a uma escola pública da capital potiguar. 


\section{RENATA DA COSTA LIMA}

Doutora e mestre em Educação pela Universidade Federal de Pernambuco. Professora da Universidade Federal da Paraíba, lotada no Departamento de Educação Básica (DEBAS). Pesquisadora da área de docência universitária e docência na educação básica, com ênfase nas representações sociais e identidade profissional docente.

\section{RENATA PORTELA RINALDI}

Doutora em Educação pela Universidade Federal de São Carlos (2009), Professora Assistente Doutora - nível II, da Universidade Estadual Paulista "Júlio de Mesquita Filho" - UNESP, atua no Departamento de Educação e no Programa de Pós-Graduação em Educação da FCT/UNESP, Presidente Prudente. Líder do grupo de pesquisa "Formação de Professores e Práticas de Ensino na Educação Básica e Superior".

\section{ROGÉRIO EMÍLIO DA SILVA}

Licenciado em Informática pelo Instituto Federal de Educação, Ciência e Tecnologia do Rio Grande do Norte (IFRN), Campus Natal - Zona Norte (2019). Técnico em Redes de Computadores pelo IFRN, Campus Parnamirim (2013).

\section{ROSANGELA SANTOS DA SILVA}

Possui Mestrado Profissional em Ensino Tecnológico pelo Instituto Federal de Educação, Ciência e Tecnologia do Amazonas. Especialização em Informática Aplicada à Educação (UNINORTE), Gestão Escolar (UFAM), Gestão e Avaliação da Educação Profissional (UFJF/CAED e Centro Paula Souza) e Graduação em Pedagogia (UFAM). É servidora efetiva do IFAM, atuando como Coordenadora Geral da Educação Profissional e Tecnológica na Diretoria de Desenvolvimento da Educação Básica DDEB/PROEN/IFAM.

\section{ROZILDA PEREIRA BARBOSA}

Especialista em Psicopedagogia pelo Instituto Superior de Teologia Aplicada (INTA) e em Gestão pedagógica na escola básica pela Universidade Estadual do Ceará (UECE), graduada em Pedagogia pela Universidade Estadual do Ceará (UECE), professora substituta na Faculdade de Educação de Crateús - FAEC desde 2014 com experiência na área de estágio curricular em Gestão Escolar, educação infantil, anos iniciais do ensino fundamental, atuando ainda nas áreas de Planejamento Educacional, Didática, Currículo e Fundamentos da Educação Infantil.

\section{SILEMAR MARIA DE MEDEIROS DA SILVA}

Possui graduação em Educação Artística (UNESC, 1986), Especialização em Arte Educação (UNESC, 1993), mestrado em Educação pela Universidade do Extremo Sul Catarinense (2009) e mestrado em Educação e Cultura pela Universidade do Estado de Santa Catarina (2004). Atualmente é professora III - Secretaria de Educação do Estado de Santa Catarina e professora horista da Universidade do Extremo Sul Catarinense desde 2001. Tem experiência na área de Artes, com ênfase em Arte na Educação, atuando principalmente nos seguintes temas: formação de professor, apreciação estética, cinema e educação, arte e infância. Coordenadora de Área do Subprojeto de Artes Visuais do Pibid Unesc (desde 2012). Coordenadora Geral do Arte na Escola Polo Unesc desde 2006. Vice Líder do Grupo de Pesquisa em Arte. Desenvolve pesquisa em Didática do Ensino da Arte.

\section{SIMONI PEREIRA BORGES}

Possui Graduação em Pedagogia pela Universidade Federal de Mato Grosso (1998). Especialização em Alfabetização pelo Instituto Cuiabano de Educação ICE - (2001), Mestre em Ensino pelo Instituto Federal de Mato Grosso/UNIC (2019). Concursada como Professora efetiva da Rede Municipal de Ensino de Campo Verde - MT, atualmente ocupa o cargo de Secretária Municipal de 
Planejamento em Campo Verde, trabalha e pesquisa na área de Formação Continuada de Professores em Campo Verde - MT.

\section{SIRLEIA PEREIRA SILVA GOMES}

Licenciado em Educação Física pela UFS. Professora de Educação Física do Estado de Alagoas. Pesquisadora do grupo de pesquisa Formação e Atuação de Educadores - INTERAÇÃO. Tem graduação em Historia. Experiência na Formação de Professores e Educação Física Escolar.

\section{TELMA MARIA DE FREITAS ARAÚJO}

Pedagoga; especialista em Psicopedagogia Clínica e Institucional; mestre e doutoranda em Educação - UFRN. Tem experiência na área de Educação, com ênfase em Educação Infantil e Anos iniciais do Ensino Fundamental. Professora aposentada da rede municipal de Natal.

\section{THAMYRIS MARIANA CAMAROTE MANDÚ}

Professora Adjunto A da Universidade Federal da Paraíba, vinculada ao Departamento de Habilitações Pedagógicas do Centro de Educação. Doutora em Educação pelo Programa de PósGraduação em Educação da UFPE (2017). Possui mestrado em Educação pela UFPE (2013) e graduação em Pedagogia, também pela UFPE (2010). Tem experiência de ensino na área de Gestão Educacional e Políticas Educacionais. Possui experiência de pesquisa na área de Formação de Professores, principalmente nos seguintes temas: curso de pedagogia, representações sociais, identidade, currículo e prática pedagógica.

\section{VALDENIZ DA SILVA CRUZ JÚNIOR}

Graduado em Ciências Atuariais pela UFRN. Mestrando em Demografia pela UFRN. Licenciando em Matemática pela UFRN. Bolsista do Programa Institucional de Bolsas de Iniciação à Docência Matemática/UFRN. 


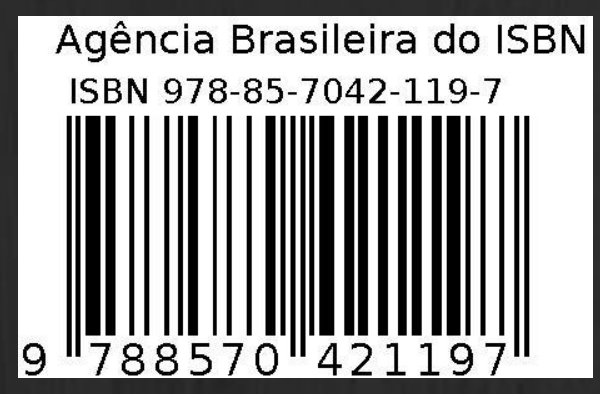

